\title{
CANDIDA PARAPSILOSIS SZEKRETÁLT ASZPARTIL PROTEINÁZOK VIRULENCIÁBAN BETÖLTÖTT SZEREPÉNEK VIZSGÁLATA
}

DOKTORI ÉRTEKEZÉS

HORVÁTH PÉTER FERENC

TÉMAVEZETŐ:

DR. GÁCSER ATTILA

TUDOMÁNYOS FŐMUNKATÁRS

\section{BIOLÓGIA DOKTORI ISKOLA}

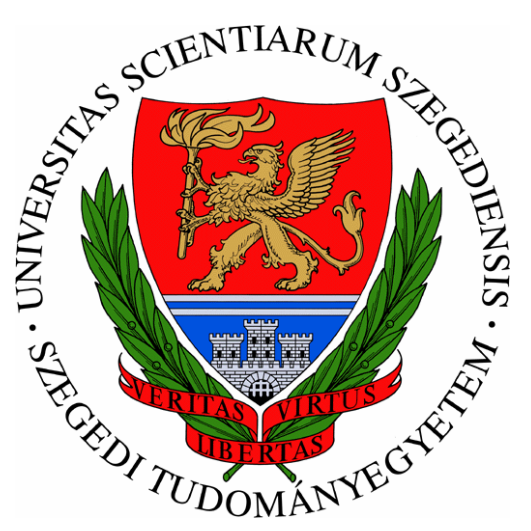

SZEGEDI TUDOMÁNYEGYETEM

TERMÉSZETTUDOMÁNYI ÉS INFORMATIKAI KAR MIKROBIOLÓGIAI TANSZÉK 


\section{TARTALOMJEGYZÉK}

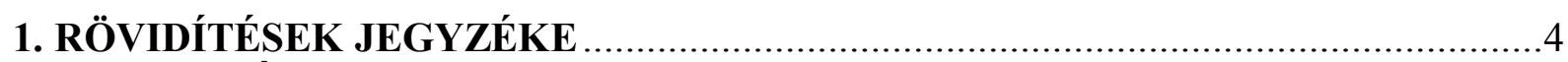

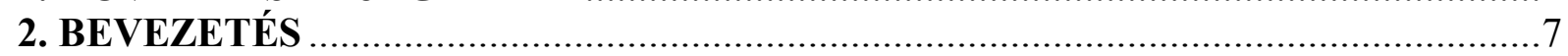

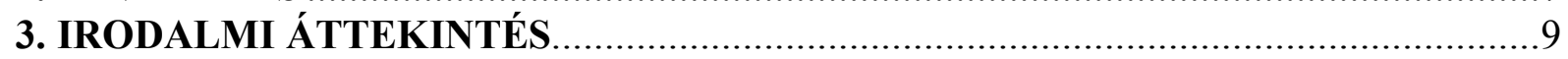

3.1. Klinikailag jelentős opportunista humán patogén Candida fajok..........................

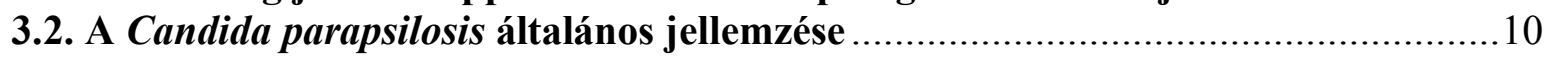

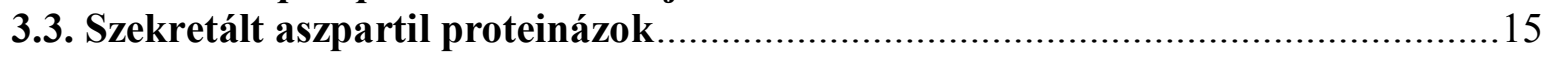

3.4. Gén deléciós és over-expressziós módszerek Candida fajokban ............................23

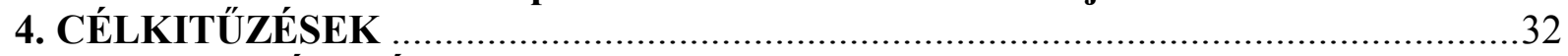

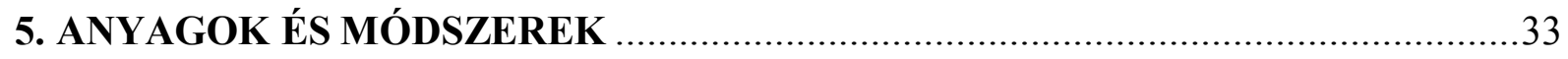

5.1. A munkánk során felhasznált mikrobák, előállított deléciós mutáns törzsek és

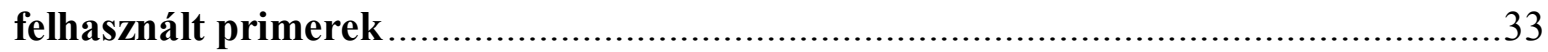

5.2. Candida transzformációhoz és Southern hibridizációhoz használt reagensek .......36

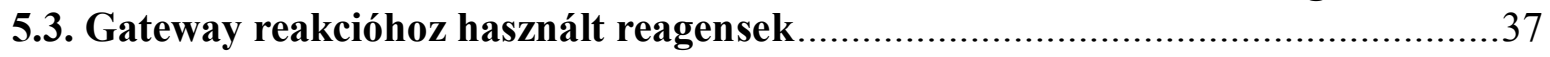

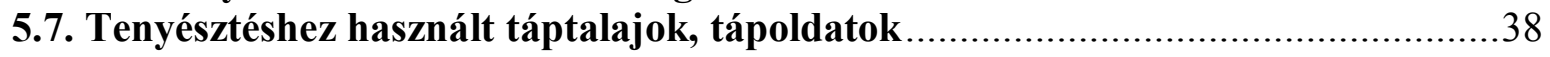

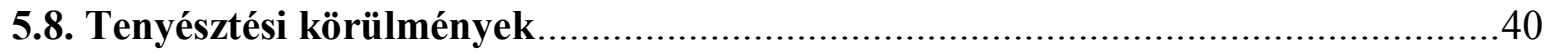

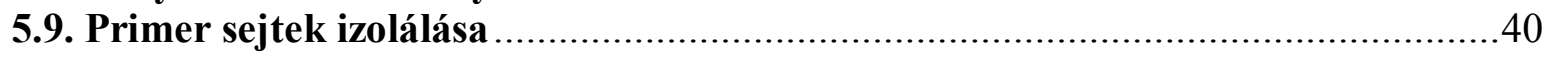

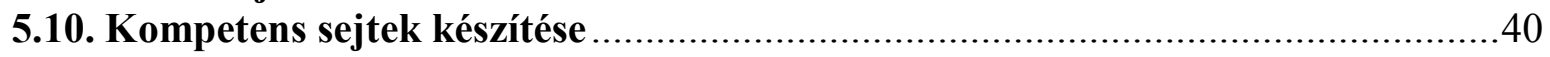

5.11. Kompetens sejtek transzformálása ....................................................................4

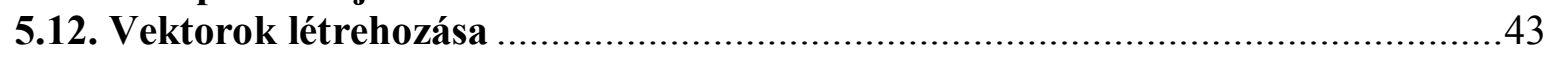

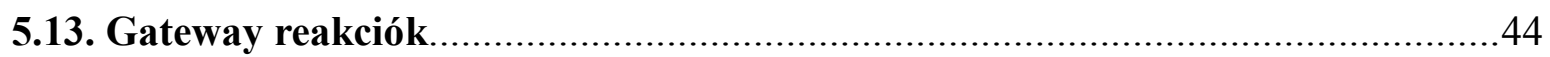

5.14. Bakteriális plazmid, gomba genomi DNS és gomba RNS tisztítása ……….........45

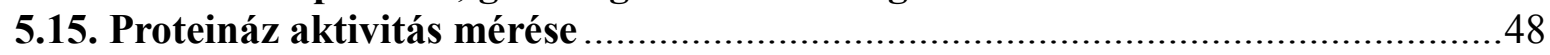

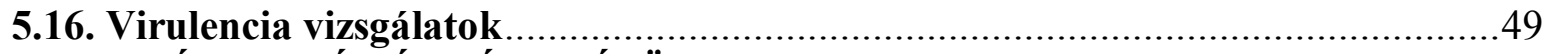

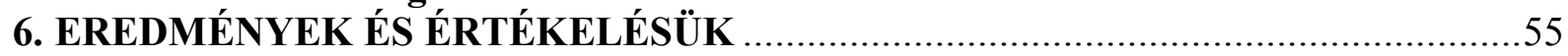

6.1. A C. parapsilosis Sapp1 fehérjének, valamint a szekretált aszpartil proteinázok általános szerepének virulenciában betöltött vizsgálata.............................................55

6.1.1. A C. parapsilosis SAPP1 lokuszának in silico analízise ...................................55

6.1.2. A $\Delta / \Delta \operatorname{sapp1a,~} \Delta / \Delta$ sapp1b és a $\Delta / \Delta \operatorname{sapp} 1 a-\Delta / \Delta \operatorname{sapp} 1 b$ homozigóta deléciós

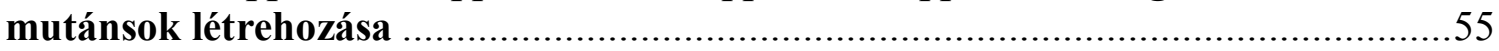

6.1.3. A C. parapsilosis $\Delta / 4$ sapp1a- $/ / \Delta$ sapp1b- $\Delta / \Delta$ sapp 2 deléciós törzs előálítása ....58

6.1.4. A szekretált aszpartil proteináz gének kvantitatív in vitro transzkripciójának

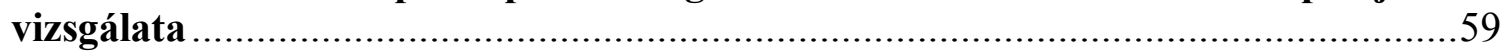

6.1.5. Az extracelluláris proteináz aktivitás vizsgálata ……………………….........61

6.1.6. A Sapp1 és Sapp2 enzimaktivitások kvantitatív vizsgálata .............................63

6.1.7. A vad típusú és a deléciós törzsek szérumérzékenységének vizsgálata ............65

6.1.8. A vad típusú és mutáns törzsek fagocitózisának vizsgálata ..............................67

6.1.9. A periferiális mononukleáris sejtek (PBMC) és abból differenciáltatott makrofágok (PBMC-DM) gombaölési hatékonysága ………………………............70

6.1.10. A gazda sejtek károsodásának mérése …………………………………....72

6.1.11. Humán PBMC-DM sejtek vad típusú és Sapp negatív törzsekkel való fertőzésre adott immunválasza ..........................................................................74

6.1.12. Nagy viaszmoly (Galleria mellonella) lárvák túlélésének in vivo vizsgálata ..75 6.1.13. A C. parapsilosis vad típusú, $\Delta / \Delta$ sapp1a- $/ / \Delta$ sapp1b és $\Delta / \Delta$ sapp1a- $\Delta / \Delta$ sapp1b-

$\Delta / \Delta$ sapp 2 törzsek sejtfalösszetételének vizsgálata...................................................76

6.2. Egy lehetséges overexpressziós rendszer alapjainak kidolgozása C. parapsilosis-

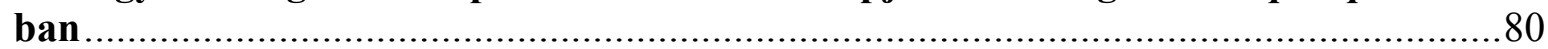

6.2.1. C. parapsilosis overexpresszióra alkalmas fogadó törzsének létrehozása. .......81 
6.2.2. Az elkészített $\boldsymbol{C}$. parapsilosis fogadó törzs GFP transzformációja .................82

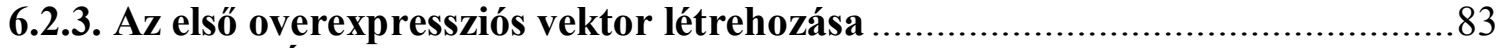

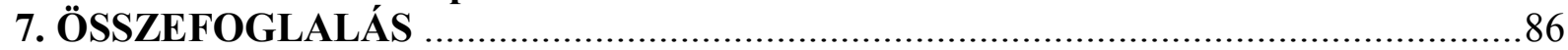

7.1. A C. parapsilosis szekretált aszpartil proteináz 1 (Sapp1) virulenciában betöltött

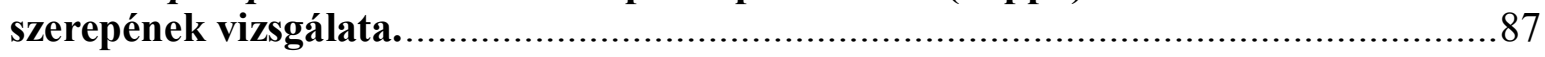

7.2. A C. parapsilosis „Sapp negatív” szekretált aszpartil proteinázt nem termelő

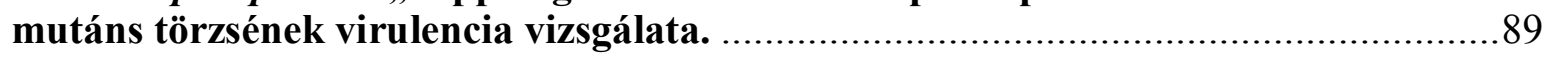

7.3. C. parapsilosis overexpressziós rendszer alapjainak kidolgozása. ......................92

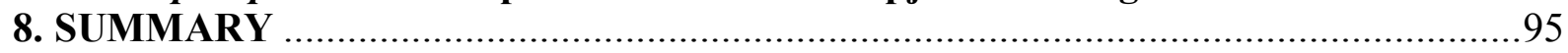

8.1. The role of secreted aspartyl proteinase 1 (Sapp1) in host-pathogen interactions.

8.2. The general role of $C$. parapsilosis secreted proteinases in virulence and host-

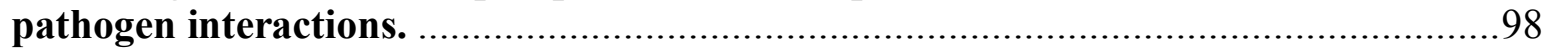

8.3. Development of an overexpression strategy for $\boldsymbol{C}$. parapsilosis ....................... 100

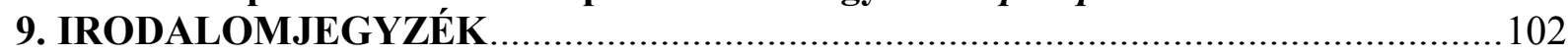

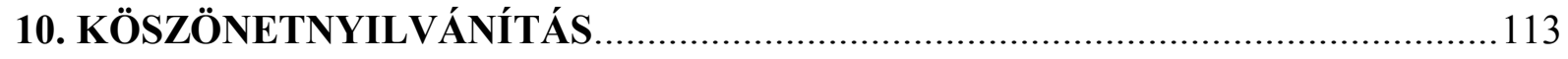




\section{RÖVIDÍTÉSEK JEGYZÉKE}

ACT1 $\quad$ Actine $1-$ Aktin 1

ANOVA Analysis of Variance Between Groups - Csoportok közti variancia analízis

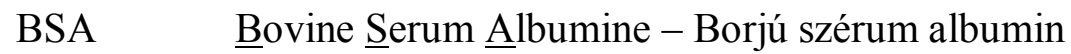

caFLP $\quad$ Candida albicans optimized Flippase - C. albicans-ra optimalizált flippáz

CD $\quad$ Cluster of $\underline{\text { Differentiation }}$

CDC $\quad$ Centers for $\underline{\text { Disease }}$ Control and Prevention

ConA Concavalin $\underline{\mathrm{A}}-$ Konkavalin A

CDR1 $\quad \underline{C}$ andida $\underline{\text { Drug }}$ Resistance Gene $\underline{1}$ - Candida drogrezisztencia gén 1

CFU $\quad$ Colony Forming Unit - Kolóniaképző egység

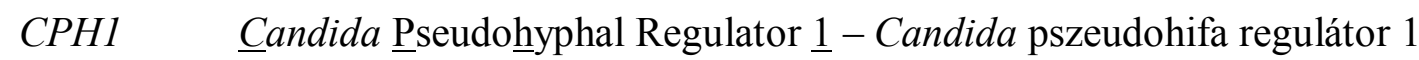

CpLIP $\quad$ Candida parapsilosis Lipase - C. parapsilosis lipáz

Cpp1 Candida Protein Phosphatase - Candida protein foszfatáz

DIG Digoxigenine - Digoxigenin

DTT Dithio Threithol - Ditiotreitol

EDTA Etylene Diamin Tetra Acetic acid - Etilén-diamin-tetraecetsav

Efg1 Enhanced filamentous growth - Megnövekedett fonalas növekedés

ELISA $\quad$ Enzyme Linked Immunosorbent Assay - Enzimkötött immunoszorbens próba

FACS $\quad \underline{F l u o r e s e n c e ~} \underline{\text { Activated }} \underline{\text { Cell }} \underline{\text { Sorter }- \text { Fluoreszencia aktivált sejtszorter }}$

FAS2 $\quad$ Fatty $\underline{\text { Acid }}$ Synthase type $\underline{2}$ - Kettes típusú zsírsav szintáz

FBS $\quad$ Fetal Bovine Serum - Embrionális borjúszérum

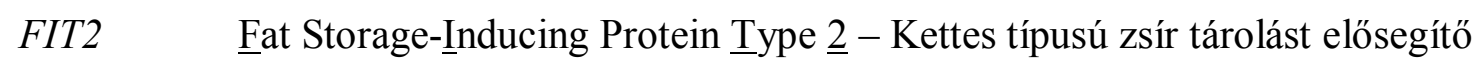
protein

FITC $\quad$ Ficoerythrine Isothiocyanate - Fikoeritrin izotiocianát

FLP $\quad$ Flippase - Flippáz

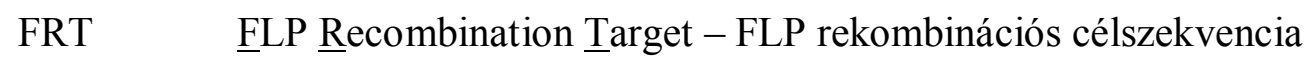

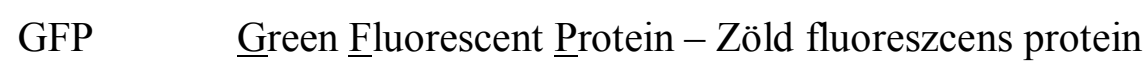

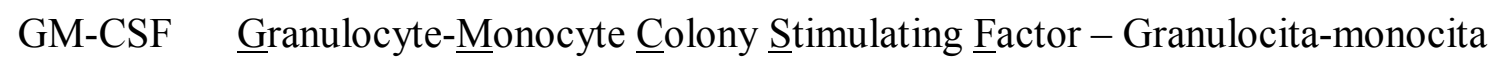
kolóniastimuláló faktor

GPI $\quad$ Glycosil Phosphatidil Inositol - Glikozil-foszfatidil-inozitol

GTW Gateway

HIV $\quad$ Human Immunodeficiency Virus - Humán immunodeficiencia vírus 


\begin{tabular}{|c|c|}
\hline hph & hygromycin B rezisztencia marker \\
\hline \multirow[t]{2}{*}{ HPLC } & High Performance Liquid Chromatography - Nagyfelbontású \\
\hline & folyadékkromatográfia \\
\hline $\operatorname{IgA}$ & Immunglobulin $\underline{\mathrm{A}}$ \\
\hline $\operatorname{IgG}$ & 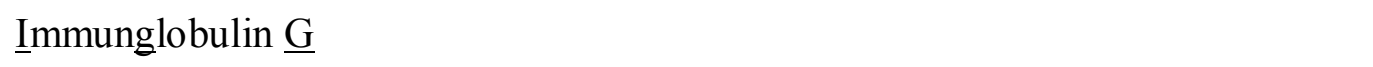 \\
\hline IL-1 $\beta$ & Interleukin $\underline{1 \beta}$ \\
\hline IL-6 & Interleukin $\underline{6}$ \\
\hline IMH3 & Inosine Monophosphate Dehydrogenase $\underline{3}$ - Inozin-monofoszfát-dehidrogenáz 3 \\
\hline Kex2 & Kexin $\underline{2}$ (Subtilizin-like protease) - Kexin 2 (szubtilizin-szerü proteináz) \\
\hline LB & $\underline{\text { Luria-Bertani tápoldat }}$ \\
\hline LDH & Lactate Dehydrogenase - Laktát dehidrogenáz \\
\hline$L I P$ & Lipase - Lipáz \\
\hline mdr1 & 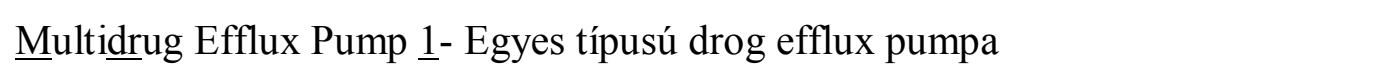 \\
\hline \multirow[t]{2}{*}{ MRSA } & 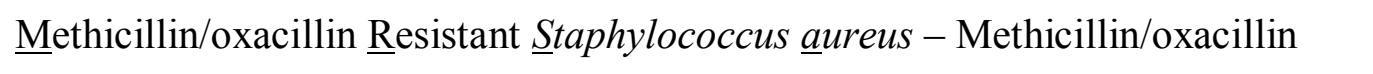 \\
\hline & rezisztens $\underline{S}$ taphylococcus aureus \\
\hline NAT & Nourseothrycine - Nourseothricin \\
\hline OLE1 & Stearoyl -coenzyme A desaturase 1 - Sztearoil koenzim A deszaturáz 1 \\
\hline PBMC & 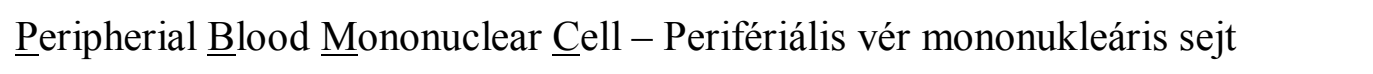 \\
\hline \multirow[t]{2}{*}{ PBMC-DM } & 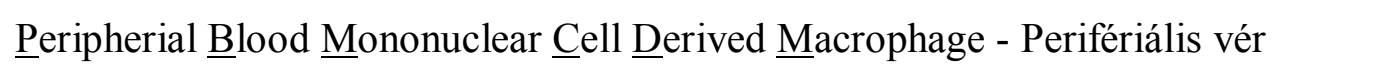 \\
\hline & mononukleáris sejtből differenciáltatott makrofág \\
\hline PBS & Phosphate Buffered Saline - Foszfátpuffer \\
\hline $\mathrm{PE}$ & Phycoerithrine - Fikoeritrin \\
\hline$P G K$ & Phosphoglycerate Kinase - Foszfoglicerát kináz \\
\hline \multirow[t]{2}{*}{ PIPES } & Piperazine-N,N'-bis(2-ethanesulfonic acid) - Piperazin-N,N'-bisz(2- \\
\hline & etánszulfonsav) \\
\hline PS & Penicillin-Streptomycin - Penicillin-sztreptomicin \\
\hline Ptet & Promoter of Tetracycline - Tetraciklin promóter \\
\hline qRT-PCR & 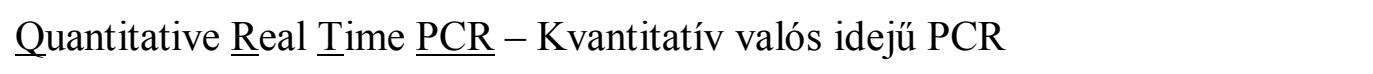 \\
\hline \multirow[t]{2}{*}{ RFLP } & 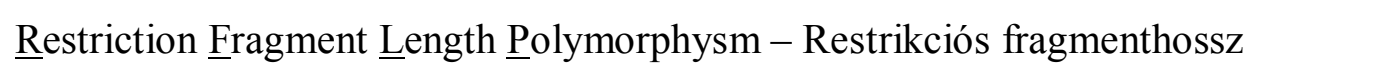 \\
\hline & polimorfizmus \\
\hline RNáz & Ribonukleáz \\
\hline$R P 10$ & 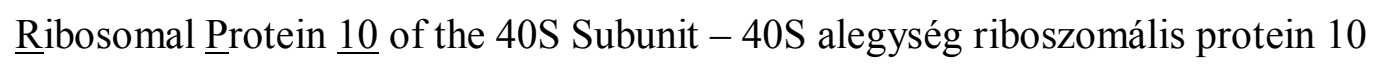 \\
\hline Rpm & 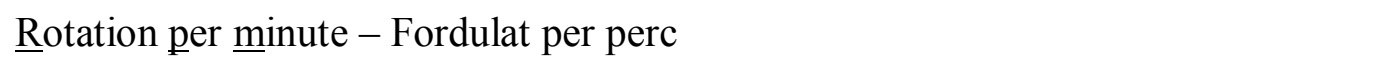 \\
\hline RPMI & 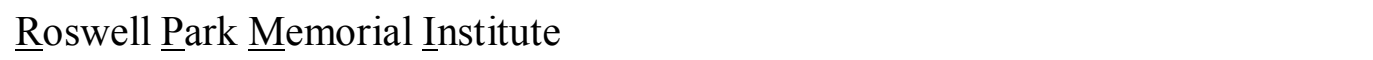 \\
\hline
\end{tabular}




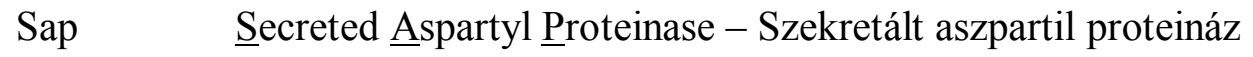

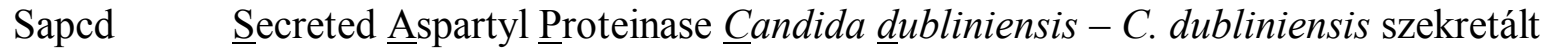
aszpartil proteináz

Sapp $\quad$ Secreted Aspartyl Proteinase Candida parapsilosis - C. parapsilosis szekretált aszpartil proteináz

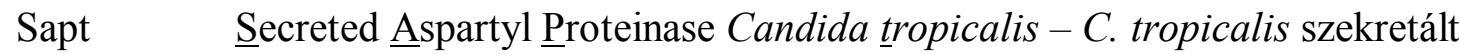
aszpartil proteináz

SAT1 $\quad \underline{\text { Streptothrycine }}$ Acetyltransferase $\underline{1}$ - Szteptotricin acetiltranszferáz 1

SDS $\quad$ Sodium Dodecyl Sulphate - Nátrium-dodecil-szulfát

SOB $\quad$ Super $\underline{\text { Optimal }}$ Broth

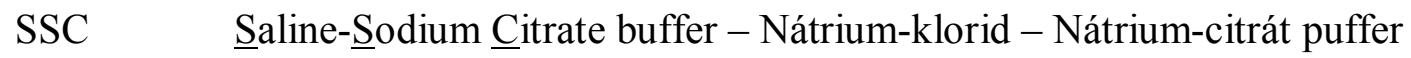

TE $\quad$ Tris-EDTA buffer - Tris-EDTA puffer

TEC1 TEA/ATTS domain Transcriptional Factor 1 - TEA/ATTS domén transzkripciós faktor 1

TEF1 1 Transcription Elongation Factor 1 - Transzkripció Elongációs Faktor 1

TEF2 Transcription Elongation Factor $\underline{2}$ - Transzkripció Elongációs Faktor $\underline{2}$

TetO Tetracycline Operator - Tetraciklin operátor

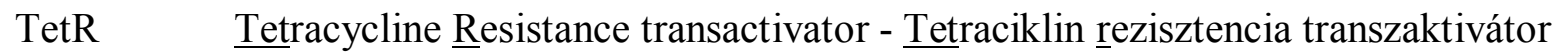

TFA $\quad$ Trifluor $\underline{\text { Acetic }} \underline{\text { Acid - Trifluor-ecetsav }}$

TNF $\alpha \quad$ Tumor Necrosis Factor $\alpha-$ Tumor nekrózis faktor $\alpha$

Tris Tris-(hydroxymethyl)-aminomethane - Tris-(hidroximetil)-aminometán

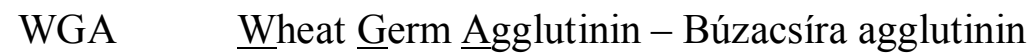

WOR1 White-Oppaque Transcriptional Regulator 1 - White-opaque transzkripciós regulátor 1

WT Wild Type - vadtípus

Yap $\quad \underline{\text { Yeast }}$ Aspartyl Proteinase - élesztő aszpartil proteináz

YCB $\quad \underline{\text { Yeast }}$ Carbon $\underline{B} a s e$ - élesztő szénbázis

YNB $\quad$ Yeast Nitrogen Base - élesztő nitrogénbázis

YPD $\quad$ Yeast extract $\underline{P}$ eptone Dextrose - élesztőkivonat pepton dextróz

Yps $\quad$ Yapsin - Yapszin 


\section{BEVEZETÉS}

Az elmúlt három évtized során az opportunista humán patogén gombák által kiváltott fertőzések száma jelentős mértékben megemelkedett. Bár jelenlegi ismereteink szerint a környezetből izolálható ismert mikroszkopikus gombák száma meghaladja a százezret, mégis a humán megbetegedésekért csupán néhány tíz tehető felelőssé. A mikózisok leggyakoribb okozói az Aspergillus nemzetségbe tartozó fonalas gombák (pl. A. fumigatus), a Cryptococcus neoformans, valamint a Candida fajok. Ezen mikrobák által okozott megbetegedések változatosak lehetnek, bizonyos körülmények között enyhébb lefolyású, felszíni, más esetekben súlyosabb, akár halálos kimenetelű szisztémás fertőzések kiváltására képesek. Bár számos Candida faj a normál, humán mikroflóra tagja, mégis a nozokomiális, szisztémás fertőzések egyik leggyakoribb kiváltói. Felmérések szerint ezen élesztők átlagosan minden harmadik egészségügyi dolgozó kezén megtalálhatók. A felnőtt lakosság körében a szisztémás kandidiázis kialakulásáért legnagyobb százalékban (akár az esetek felében) a Candida albicans tehető felelőssé. Különösen veszélyeztetettek az elégtelen immunrendszerrel rendelkező, vagy szerv transzplantáción átesett betegek és a HIV fertőzöttek. Újszülöttek körében, a kandidiázisos esetekért felelős ágensek között a C. parapsilosis okozta megbetegedések száma sok esetben a $C$. albicans által okozott megbetegedések esetszámát is felülmúlja. Ennek egyik oka lehet, hogy a C. parapsilosis előzetes kolonizáció nélkül is képes megbetegedések kiváltására, az egészségügyi dolgozók kezéről, vagy nem steril klinikai eszközök segítségével juthat a kórházban tartózkodó újszülöttre. A veszélyeztetett célcsoport különbözősége a gazda-patogén kölcsönhatás eltérő mivoltára enged következtetni.

Mivel a kandidiázis leggyakoribb kiváltója a C. albicans, ezért kezdetben, mintegy három évtizeddel ezelőtt a molekuláris és genetikai vizsgálatok ezzel a fajjal kezdődtek meg. A mikroba virulenciájának kialakulásában (mind C. albicans, mind C. parapsilosis esetén) fontos szerepet játszik a gazda felületén való megtapadás képessége. Azon fajok, amelyek a megtapadás után biofilm formálásra képesek, jóval virulensebbnek bizonyulnak, mint a biofilm képzésre képtelen fajok. C. albicans esetén jelentős virulencia faktor a hifa képzés képessége, amely a gazda szöveteibe való behatolást segítheti elö. Ezzel ellentétben a $C$. parapsilosis valódi hifa képzésére nem, csupán pszeudohifa képzésére képes. Mindkét mikroba esetén a virulencia kialakulásában fontos szerep jut a szekretált hidrolitikus enzimek termelésének. Ezek közül legfontosabb szerepük a szekretált lipázoknak, szekretált aszpartil proteinázoknak és kisebb mértékben a szekretált foszfolipázoknak van. C. albicans-ban egészségügyi fontosságánál fogva - ezek a virulencia faktorok széles körben 
tanulmányozottak, ellentétben a $C$. parapsilosis-sal. A legtöbb tanulmány, amely a $C$. albicans virulencia faktorait tanulmányozta, valamilyen, az adott virulencia faktorra homozigóta deléciós törzset használt fel. Bár C. albicans esetén számos, eredményesen müködő géndeléciós módszert kidolgoztak, addig a géneket túlmüködtető stratégiák kidolgozása jelenleg is folyamatban van. C. parapsilosis esetén a gén deléciós stratégiák száma jóval korlátozottabb, míg géneket túlműködtető stratégia ezidáig nem állt rendelkezésre ezen mikroba esetén. Annak érdekében, hogy a genetikai manipulációk repertoárját $C$. parapsilosis esetén gazdagítsuk, valamint az egyes gének funkciójának vizsgálatához új módszert biztosítsunk, munkánk során sikeresen kidolgoztunk egy géneket túlmüködtető rendszert, amelynek segítségével azok a mutációk is tanulmányozhatóvá válnak, melyek a gén deléció során potenciálisan letális fenotípusúnak bizonyulnak.

Számos C. albicans-on végzett vizsgálat kimutatta ezen mikroba szekretált aszpartil proteináz izoenzimeinek, mint virulencia faktoroknak a szerepét a gazdával való interakció során. C. albicans esetén tíz szekretált aszpartil proteináz génből álló géncsaládot azonosítottak (SAP1-SAP10). Minden SAP gén kifejeződése szigorúan szabályozott. A kifejeződés függ a mikroba életciklusától (pl. élesztő - hifa átmenet), az esetleges fertőzés típusától, helyétől és annak előrehaladott állapotától. A fertőzés kezdeti stádiumában a szekretált aszpartil proteinázok képesek a gazda szöveti integritásának megbontására, így biztosítva a mikroba terjedését. Szisztémás kandidiázis kialakulása során a szekretált aszpartil proteinázok képesek számos strukturális és immunológiailag fontos fehérje bontására, elősegítve ezzel a mikroba terjedését. A C. albicans Sap izoenzimeinek jelentőségét mutatja, hogy ezen szekretált enzimek felhasználásával a közelmúltban megkezdődött egy C. albicans elleni vakcina kidolgozása. Ezzel ellentétben $C$. parapsilosis esetén, bár az ismert szekretált aszpartil proteináz izoenzimek enzimológiai jellemzése megtörtént, a gazda - patogén interakció során betöltött szerepükről mindezidáig minimális ismeretek álltak rendelkezésünkre. A $C$. parapsilosis szekretált aszpartil proteinázok virulenciában betöltött szerepének tanulmányozása érdekében munkánk során $C$. parapsilosis szekretált aszpartil proteináz génekre deléciós mutáns törzseket hoztunk létre. Az előállított deléciós mutánsok segítségével lehetőség nyílt a szekretált aszpartil proteinázok funkciójának, valamint virulenciában betöltött szerepük vizsgálatára, mind in vitro, mind in vivo modellrendszerek segítségével. 


\section{IRODALMI ÁTTEKINTÉS}

\subsection{Klinikailag jelentős opportunista humán patogén Candida fajok}

Az elmúlt három évtized során az opportunista humán patogén gombák által kiváltott invazív megbetegedések száma nagymértékben megnövekedett, így új antifungális stratégiák kidolgozása, az antifungális szerekkel szembeni rezisztencia és a gazda - patogén kölcsönhatások alaposabb megértése napjainkra egyre sürgetőbbé vált (Pfaller és mtsai. 2007).

A normál humán mikroflóra felépítésében számos mikroba részt vesz. Születés után kialakul a mikrobák természetes egyensúlya. Erre a baktériumok dominanciája jellemzö, de számos, az Ascomycota és Basidiomycota csoportba tartozó gombafaj is jelen van (Filippidi és mtsai. 2014). Egészséges egyénekben ezen fajok anélkül vannak jelen, hogy a gazdaszervezetben bármilyen kórfolyamatot kiváltanának. Opportunista humán patogén gombák által kiváltott megbetegedések legtöbb esetben akkor következnek be, amikor a gazda által adott immunválasz valamely oknál fogva elégtelen (pl. szerv transzplantáció, HIV fertőzés) és a szervezet képtelen a megfelelő védekezésre, így ezen mikrobák fertőzések kialakítására képesek. Humán mikózisok kiváltásában legnagyobb részben Aspergillus, Cryptococcus és Candida fajok vesznek részt (Pfaller és mtsai. 2007).

Számos Candida faj mint a normál, humán mikroflóra alkotói vannak jelen a bör, valamint a nyálkahártyák felszínén. Az elmúlt harminc év során a Candida fajok által okozott megbetegedések egyre növekvő tendenciát mutattak (Pfaller és Diekema 2007). Ezen fajok felszíni és invazív szisztémás fertőzéseket egyaránt kiválthatnak. Felszíni fertőzések során föként a köröm, bőr, valamint az ivarszervek érintettek. Szisztémás fertőzés során a mikroba a véráramba kerül, így a véráram közvetítésével a belső szervek megbetegedését is kiválthatja. Pfaller és Diekema tanulmánya szerint az Egyesült Államokban 100.000 före vetítve átlagosan 29 esetet regisztráltak (Pfaller és Diekema 2007). Több tanulmány szerint a felnőtt lakosság körében a kandidiázis okozta mortalitási arány rendkívül magas, amely az összes kandidémiás eset akár 50\%-át is megközelítheti (Pappas és mtsai. 2003, Moran és mtsai. 2009). A felnőtt lakosság körében a kandidiázis kiváltásáért föként a C. albicans felelős, ám az egyéb nem-albicans fajok(C. parapsilosis, C. glabrata, C. tropicalis, C. krusei) által okozott megbetegedések növekvő tendenciát mutatnak az ezredforduló óta (Pfaller és mtsai. 2007, Papon és mtsai. 2013). Különböző korcsoportokat vizsgálva a kandidémiát kiváltó mikrobák részaránya eltérő. Fiatalabb korcsoportok, elsősorban csecsemők, újszülöttek körében a C. parapsilosis részaránya kiemelkedően magas (Trofa és mtsai. 2008, Chow és mtsai. 2012). 


\subsection{A Candida parapsilosis általános jellemzése}

A mintegy 200 fajt magába foglaló CUG klád számos tagja a környezetből izolálható (Pereira és mtsai. 2013, Pryszcz és mtsai. 2013). Néhány tagjuk biotechnológiai jelentőséggel is bír (Dias és mtsai. 2000), míg a nemzetség döntő többsége magasabb rendü gazdaszervezettel él kommenzalista kapcsolatban. A kládra jellemző, hogy az univerzális kódhasználattól eltérően a transzláció folyamata során, CUG kodon esetében szerin beépülése valósul meg leucin helyett. (1. ábra) (Butler és mtsai. 2009).

A C. parapsilosis-t elöször Ashford izolálta 1928-ban Puerto Rico-ban, egy hasmenéses beteg székletéből. Az új fajt Monilia parapsilosis-ként írta le, megkülönböztetve az akkor már ismert és jóval nagyobb gyakorisággal izolált Monilia psilosis (mai nevén $C$. albicans) fajtól (Weems 1992).

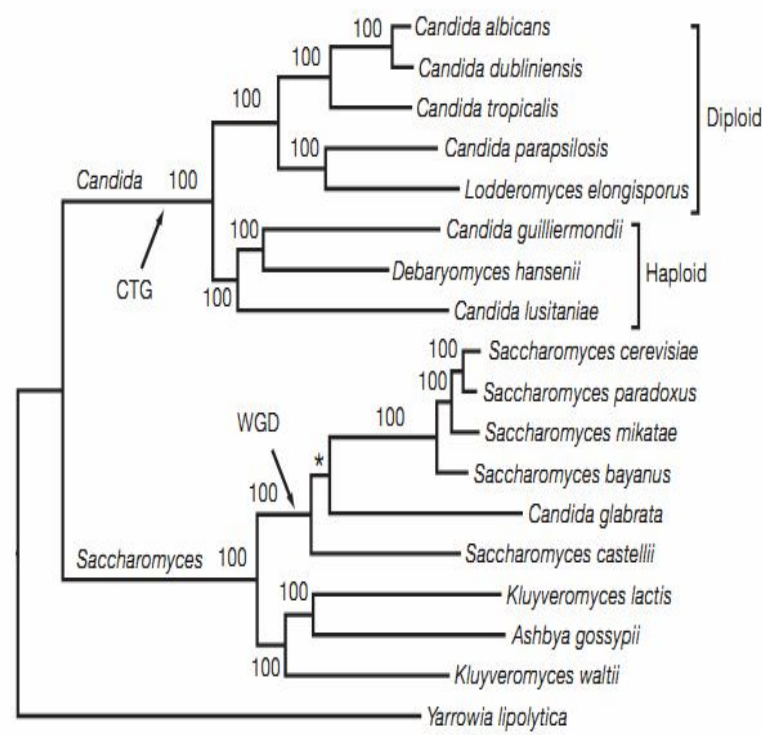

1. ábra

A C. parapsilosis filogenetikai helyzete (Butler és mtsai. 2009).

A C. parapsilosis diploid organizmus, ezidáig csak ivartalan szaporodási ciklusa ismert, amely sarjadzással történik. Teljes genom szekvenciája 2009-ben vált elérhetővé (Butler és mtsai. 2009). A referenciaként használt CDC317 jelü törzs alapján haploid genommérete 13,1 Mb, génjeinek száma mintegy 5700 (Butler és mtsai. 2009). Korábban a $C$. parapsilosis-ként ismert faj három alcsoportot foglalt magában (I, II, III), melyek sok tekintetben eltértek egymástól. 2005-ben a három alcsoport bevonásával elvégzett, több lokuszt magába foglaló szekvencia analízis eredményeként az eddig egységesnek tekintett $C$. parapsilosis fajcsoportot három, egymástól különálló fajjá választották szét. Ezek alapján napjainkban az I. csoportot $C$. parapsilosis, a II. csoportot $C$. orthosilosis, míg a III. csoportot 
C. metapsilosis-ként tartják számon (Tavanti és mtsai. 2005). Érdekes módon a $C$. parapsilosis mitokondriális genom struktúrájára jellemző, hogy eltérően $S$. cerevisiae, $C$. albicans, C. tropicalis fajoktól, ezen faj esetén lineáris szerkezetü mitokondriális genomot találunk. A lineáris mitokondrium $30 \mathrm{~kb}$ nagyságú, szerkezetére jellemző, hogy végén az eukariota organizmusok telomer szekvenciájához hasonló ismétlődő struktúrát tartalmaz. A mitokondriális genom nagymértékben kompakt. A mitokondriális genomban megtalálható a légzési lánc tagjainak 14 fehérjéje, az ATP szintáz gén, valamint a mitokondriális riboszómák kis és nagy alegységének felépítésében részt vevő riboszomális RNS gének (Kovac és mtsai. 1984, Nosek és mtsai. 1995, Valach és mtsai. 2012).

Az élesztő sejtek kerek vagy ovális alakot vehetnek fel. Bizonyos körülmények között, főként citrullin jelenlétében, pszeudohifa képzésre képesek, ám valódi hifát nem képeznek (Kim és mtsai. 2006). Makroszkópos megjelenésére jellemző, hogy laboratóriumi körülmények között, komplett táptalajon (YPD, Sabouraud dextróz agar) tenyésztve a telepek fehér, krémszerü megjelenésűek, a telep felszíne törzstől függően lehet sima, karéjos vagy gyürött. A mikroba jellemzően az egészséges humán mikroflóra részét képezi, ám a növényekről és a talajból izolálható formái is ismertek (Pryszcz és mtsai. 2013).

Hasonlóan a C. albicans-hoz, a C. parapsilosis sejtfal szerveződésére is egy belső, kompaktabb és egy külső, lazább réteg a jellemző. A belső réteg felépítésében kitin, valamint erre ráépülve $\beta-1,3$ glükán váz vesz részt. A sejtfal külső, lazább rétege fehérjékkel asszociált O és N kötött mannóz polimerböl épül fel. A két réteget kovalensen kötött $\beta$-1,6-glükánglikofoszfatidilinozitol kapocs rögzíti egymáshoz (Netea és mtsai. 2008). A sejtfal komponenseinek minősége és részaránya nem állandó az élesztő sejtciklusa alatt, hanem egy jól szabályozott, komplex folyamatnak köszönhetően dinamikusan változik (Gow és mtsai. 2012). Bizonyos körülmények között a citokinézis nem fejeződik be, a lefüződő leánysejt nem hagyja el az anyasejtet, hanem erőteljesen megnyúlik, ezzel pszeudohifa jöhet létre (Buffo és mtsai. 1984, Mardon és mtsai. 1969).

Számos regionális és nemzetközi tanulmány vizsgálta a Candida fajok epidemiológiáját. A 2000 előtti tanulmányok egyértelműen rávilágítanak, hogy legnagyobb mértékben, az összes eset mintegy 37-70\%-ában a C. albicans felelős a szisztémás kandidiázis kórképének kiváltásáért (Pfaller és mtsai. 2007). Ezzel szemben, az ezredforduló óta egy újabb trend figyelhető meg, miszerint kandidémiás esetek egyre kisebb részéböl izolálható C. albicans, míg az eddig kisebb jelentőséggel bíró és ezidáig kevésbé tanulmányozott nem-albicans fajok egyre nagyobb részarányban okoznak megbetegedéseket. Újabb felmérések szerint Európa valamint Észak-Amerika területén a $C$. albicans által 
okozott megbetegedések részaránya mintegy 50\%, ezzel szemben a C. glabrata, $C$. parapsilosis, $C$. krusei valamint a $C$. tropicalis által okozott megbetegedések száma növekszik (Papon és mtsai. 2013, Tortorano és mtsai. 2013). Latin-Amerikában és DélAfrikában a nem-albicans fajok által okozott megbetegedések részaránya még az előbbieknél is nagyobb mértékü. Ezeken a területeken az izolátumoknak kevesebb, mint a fele bizonyult $C$. albicans-nak, míg a nem-albicans fajok közül föként a C. parapsilosis emelkedik ki, amely az összes kandidémiás megbetegedés mintegy 25 \%-áért volt felelős (Nucci és mtsai. 2013, Kreusch és Karstaedt 2013). Ezeken a területeken a kandidémiás esetek mortalitási rátája kiemelkedően magas, mintegy 60-73\% közötti (Kreusch és Karstaedt 2013).

Számos tanulmány felhívja a figyelmet arra a jelenségre, hogy különböző korcsoportokat vizsgálva a kandidémiát kiváltó mikrobák részaránya eltérő. Fiatalabb korcsoportok, elsősorban csecsemők, újszülöttek körében a C. parapsilosis részaránya kiemelkedően magasnak bizonyul (Trofa és mtsai 2008, Chow és mtsai. 2012). A különböző geográfiai területekről származó beszámolók szerint az újszülötteket érintő C. parapsilosis által okozott megbetegedések száma meghaladja a C. albicans által okozott megbetegedések számát (Pammi és mtsai. 2013, Neu és mtsai. 2009). Számos, több évre kiterjedő felmérés eredménye szerint újszülöttek körében a candidémiák kialakulásáért a C. parapsilosis mintegy 30-50\%-ban tehető felelőssé (Trofa és mtsai. 2008, Neu és mtsai. 2009, Chow és mtsai. 2012) (2. ábra).

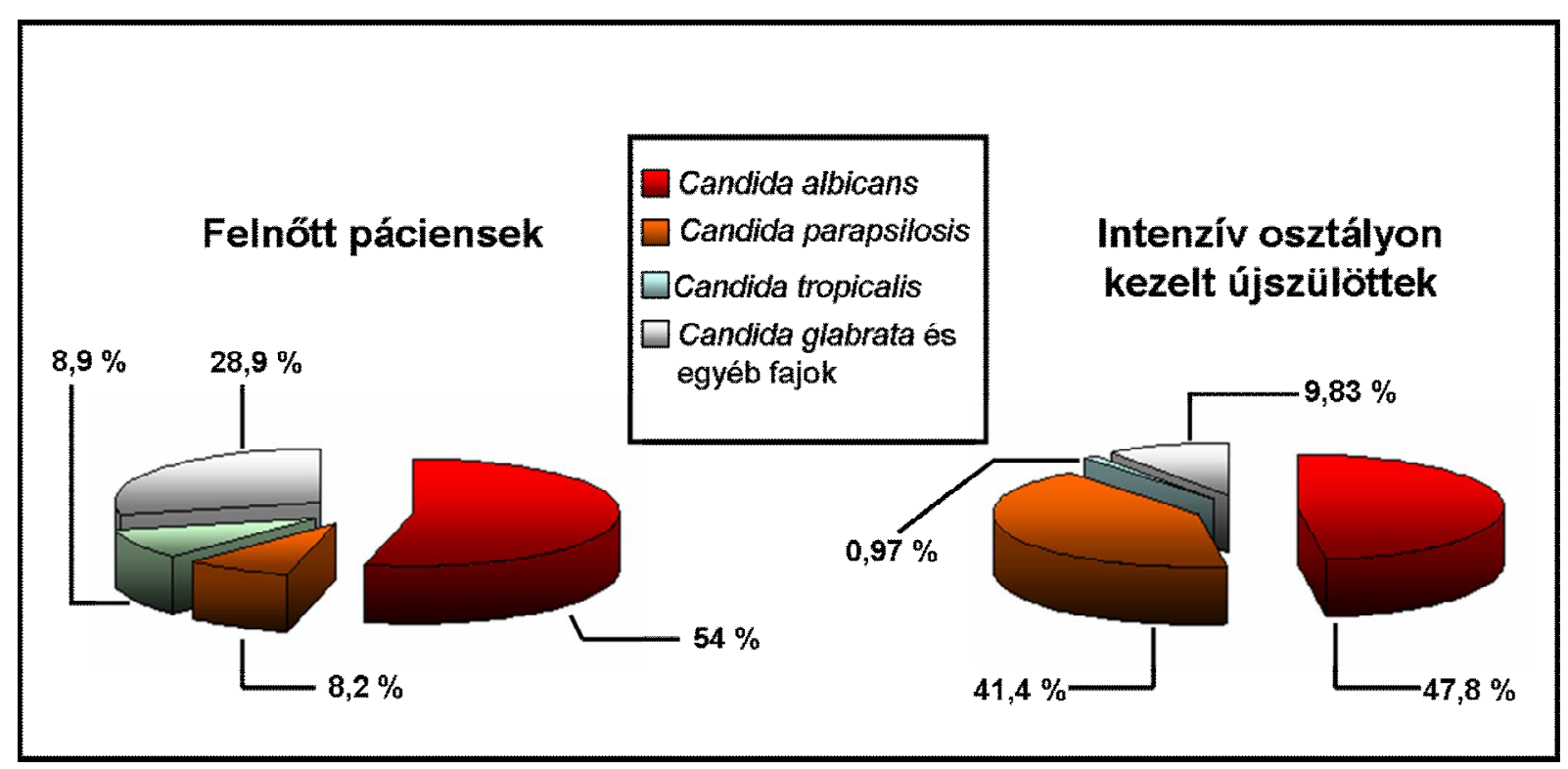

2. ábra

Szisztémás kandidiázist kiváltó fajok megoszlása újszülött és felnőtt páciensek körében (Chow és mtsai. 2012 alapján) 
Egy tanulmány kimutatta, hogy míg a $C$. albicans a születés során kolonizálja az újszülöttet, addig a C. parapsilosis csupán hetekkel később jelenik meg az újszülött mikroflórájában, ez a tény arra utal, hogy a C. parapsilosis előzetes kolonizáció nélkül is képes fertőzések kiváltására (Parm és mtsai. 2011). Számos tanulmány felhíva a figyelmet arra, hogy az alacsony születési súllyal világra jött újszülöttek C. parapsilosis fertőzések szempontjából különösen veszélyeztetett csoportot képeznek. Az a tény, hogy ezen mikroba nagy gyakorisággal izolálható egészségügyi dolgozók kezéről, magyarázatot adhat ezen megfigyelésre (Trofa és mtsai. 2008, Chow és mtsai. 2012). Rizikófaktorként tartjuk számon a vénás katéterek alkalmazását, a hosszan tartó antibiotikumos kezelést, sebészeti beavatkozást, szervátültetést, neutropéniás állapotot, valamint újszülöttek esetén az alacsony születési súlyt (Almirante és mtsai. 2006).

A szisztémás kandidiázis kialakulásában kiemelkedő szerepet játszik a mikroba biofilm képző képessége, valamint a szekretált hidrolitikus enzimek termelése. Újabb tanulmányok rámutatnak, hogy ezen virulencia faktorokon kívül a gomba zsírsav szintézisében szerepet játszó fehérjék szintén fontos virulencia faktorok (Nguyen és mtsai. 2009, Nguyen és Nosanchuk 2011, Nguyen és mtsai. 2011). A mikrobára jellemzö, hogy hatékonyan képes megtapadni és biofilmet képezni nem csak a gazdaszervezeten, hanem a klinikumban használatos egyéb müanyag felszíneken egyaránt. A megtapadás kezdeti szakaszában nagy jelentőséggel bírnak a hidrofób felszínek. C. parapsilosis adhéziós képessége akril anyagú felületekhez mintegy másfélszer jobb, míg a szájüregi epitéliális sejteken való megtapadási képessége 20\%-al jobb, öszzevetve a C. albicans-sal (Panagoda és mtsai. 2001). A C. parapsilosis által képzett biofilmek a C. albicans-sal összevetve jóval vékonyabbak, egyszerübb felépítésüek. Általánosságban a pszeudohifák jóval nagyobb gyakorisággal képeznek biofilmet, mint az élesztő formák (Laffey és Butler 2005). Bár a mikroba biofilm képzésének molekuláris mechanizmusa kevéssé ismert, egy tanulmány kimutatta, hogy a BCRl transzkripciós faktorra deléciós mutáns törzs biofilm képző képessége szignifikánsan csökkent a vad típusú törzshöz képest, így ezen transzkripciós faktor a biofilm képzés egyik központi szabályozó eleme lehet (Ding és Butler 2007). Továbbá, egy vizsgálat megállapította, hogy bizonyos aminosavak jelenléte elősegíti a biofilm képzést (Kim és mtsai. 2006), valamint a lipáz termelésben deficiens $C$. parapsilosis törzs biofilm képzési képessége szintén nagymértékben csökkent (Gácser és mtsai. 2007c).

Számos tanulmány vizsgálta a $C$. parapsilosis zsírsav szintézisének virulenciában betöltött szerepét. Érdekes módon a zsírsav bioszintézis folyamatában részt vevő enzimek 
szerepet játszanak a kiváltott immunválaszban, a biofilm képzésben és hozzájárulnak a virulenciához in vivo kísérletes egér modellben. A FAS2 (kettes típusú zsírsav szintetáz) homozigóta deléciós mutáns törzs nem volt képes biofilm képzésre és a gazda effektor sejtjei nagyobb hatékonysággal eliminálták a gombasejteket (Nguyen és mtsai. 2009). Az OLE1 (sztearolil koenzim A deszaturáz 1) deléciós mutáns törzs sejtjei nem voltak képesek pszeudohifa képzésre, valamint ozmotikus és oxidatív stresszre való érzékenységük is megnövekedett. Ezen felül humán szérummal szemben szintén szenzitívnek bizonyultak (Nguyen és Nosanchuk 2011). A FIT2 (kettes típusú zsír tárolást elösegítő protein) homozigóta deléciós mutáns törzse szintén érzékenynek bizonyult ozmotikus stresszre, valamint csökkent virulenciát mutatott in vivo kísérletes egér modellben (Nguyen és mtsai. 2011).

A gomba által szekretált hidrolitikus enzimek közül a virulencia kialakításában kiemelt jelentőséggel bírnak a lipázok, és aszpartil proteinázok. A foszfolipázok virulenciában betöltött szerepe ezzel szemben kisebb jelentőségünek bizonyul.

A foszfolipázok alapvető funkciója a foszfatidil glicerolok észter kötéseinek hidrolízise. Bár a foszfolipázok fertőzésben betöltött szerepe ezidáig kevéssé tanulmányozott, az általános elképzelés szerint ezen enzimek funkciója a gazda sejtek membrán integritásának megbontása (Ghannoum 2000, Kantarcioglu és Yucel 2002). C. albicans esetén számos tanulmány demonstrálta a foszfolipázok virulenciában betöltött szerepét. Ezen tanulmányok szerint a foszfolipázoknak szerepük van a virulencia kialakításában egér szisztémás modell esetén, szerepük van az epitéliális sejtekhez való adhézióban (Barrett-Bee és mtsai. 1985), a gazda sejtbe való penetráció során (Pugh és Cawson 1977), humán epitéliális sejtek inváziójában (Jayatilake és mtsai. 2005), valamint a gazda jelátviteli útvonalainak módosításában (Filler és mtsai. 1991). A C. parapsilosis foszfolipázok virulenciában betöltött szerepe nem ennyire egyértelmü. Egyes szerzők beszámoltak foszfolipáz aktivitásról számos klinikai eset kapcsán (Ghannoum 2000), ugyanakkor mások nem mutattak ki ilyen jellegü enzimaktivitást (Kantarcioglu és Yucel 2002). Egy publikáció szerzői csak a szisztémás fertőzésekből származó izolátumok esetén mutattak ki enzimmüködést (Dagdeviren és mtsai. 2005), míg mások bőrfelszíni izolátumokban detektáltak enzimaktivitást (Fernanado és mtsai. 1999).

A szekretált lipázok katalizálják a triacil glicerolok hidrolízisét és szintézisét egyaránt. Jellemző rájuk a proteolízissel szembeni rezisztencia, a magas hőstabilitás és szerves oldószerekben a magas enantioszelektivitás (Brockerhoff 1974). Általánosságban elmondható, hogy a mikrobiális extracelluláris lipázok szerepe meglehetősen sokrétü. Elsődleges szerepük 
a lipidek hidrolízise, így azok szénforrásként való hasznosítása. Ezen az alapvető funkción kívül a szekretált lipázok szerepet játszanak a mikroba gazda szövetein való megtapadás folyamatában, az immunfolyamatok beindításában, illetve azok modulálásában, valamint szerepet játszanak a mikroba védekezésében azáltal, hogy az esetlegesen kompetítorként jelen levő mikroflóra szaporodását gátolják (Schaller és mtsai. 2005, Stehr és mtsai. 2004). C. albicans esetén tíz szekretált lipáz gént azonosítottak (LIP1-LIP10) (Hube és mtsai. 2000). Szisztémás egér modellben a fertőzést követő 4 óra elteltével a C. albicans LIP8 génje mutatott nagyfokú transzkripciós szintet (Stehr és mtsai. 2004).A vad típusú törzsböl származtatott $\Delta / \Delta$ lip 8 deléciós mutáns törzzsel elvégezve a kísérletet a vad típusú törzshöz képest nagyfokú virulencia csökkenés volt tapasztalható (Gácser és mtsai. 2007b).

C. parapsilosis-on végzett vizsgálatok két lipáz gént azonosítottak (CpLIP1,CpLIP2), bár csupán a CpLIP2 gén kódol aktív fehérjét (Brunel és mtsai. 2004). A C. parapsilosis szekretált lipázának virulenciában betöltött szerepét jól demonstrálja, miszerint vad típusú $C$. parapsilosis törzset alkalmazva humán szöveten végzett in vitro fertőzéses modellben, a fertőzés során lipáz inhibitort alkalmazva a szöveti károsodás mértéke szignifikánsan kisebb volt, összevetve a csak vad típusú $C$. parapsilosis törzs által okozott szöveti károsodással (Gácser és mtsai. 2007c). Gácser és munkatársai a homozigóta $\Delta / \Delta C p L I P 1-\Delta / \triangle C p L I P 2$ (lipáz deficiens) C. parapsilosis törzs vizsgálata során megállapították, hogy a mutáns törzs kevesebb, kevésbé komplex biofilm formálására képes, mint a vad típusú törzs, lipid gazdag tápközegben a növekedése csökkent mértékü a vad típusú törzzsel összevetve. Ezen felül makrofág sejtek jóval eredményesebben fagocitálják és eliminálják ezen mutáns törzs sejtjeit in vitro fertőzéses kísérletek során, valamint csökkent virulenciát mutatnak in vivo állatkísérletek során (Gácser és mtsai. 2007c). A lipáz negatív törzsön végzett megfigyelések rendkívüli fontossággal bírnak, hiszen a $C$. parapsilosis által okozott fertőzések különösen nagy gyakorisággal fordulnak elő olyan alacsony születési súllyal rendelkező újszülöttek körében, akik lipid gazdag táplálásban részesülnek.

\subsection{Szekretált aszpartil proteinázok}

Minden proteináz alapvető feladata a peptid kötések hidrolízise, bár a specificitás tekintetében jelentős különbségek mutathatók ki (Barrett és Rawlings 1991). A proteinázok családja hatásmechanizmusuk alapján négy típusra oszthatóak: szerin, cisztein, metallo és aszpartil proteinázok. Szerin proteinázokra példa a tripszin, kimotripszin és szubtilizin alcsaládok, a cisztein proteinázok között találjuk a Streptococcus fajok proteinázait, valamint a papaint, míg a metalloproteinázok körébe tartoznak a kollagenázok és a mikrovillus 
proteinázok (Barrett 1979). Az aszpartil proteinázok széles körben elterjedtek és számos biokémiai reakció katalíziséért felelősek (Davies 1990). Jól ismert aszpartil proteinázok a HIV aszpartil proteináza, a humán pepszin és renin.

Élesztők körében az aszpartil proteinázok családján belül két nagyobb csoportját különböztetik meg: az első csoportba az úgynevezett élesztő aszpartil proteinázok (yeast aspartyl proteinase/yapsin - Yap/Yps) tartoznak (Krysan és mtsai. 2005), míg a második csoportot a szekretált aszpartil proteinázok ( (Hruskova-Heidingsfeldova 2008).

A yapszin fehérjék alapvető funkciója a sejtfal integritásának megőrzése, valamint szerepük van a sejt-sejt közötti interakciókban is. Szintézisük során, hasonlóan más aszpartil proteinázokhoz, a yapszin fehérjék szintén inaktív zimogénként szintetizálódnak. A zimogénen belül az aktív centrumot egy proszegmens fedi el. Ez a proszegmens egy sóhíd által stabilizálódik, amely a zimogén propeptidjének lizin és a katalitikus diád aszparaginsav maradéka közt található. Savas környezetben az aszparaginsav aminosav protonálódása a sóhíd felbomlásához vezet, melynek során a zimogén aktiválódása elkezdődik. Az aktiválódás két lépésből áll: elsőként a propeptid egy intramolekuláris reakció során hasítódik, majd második lépésként a proszegmens vágódik le az érett enzimről (Gagnon-Arsenault és mtsai. 2006). A yapszin család fehérjéi között a katalitikus domén a leginkább konzervált régió. Az aktív centrumban két aszparaginsav fedezhető fel, egy erösen konzervált szekvencia motívumon belül. A központi motívum: Xaa-Xaa-Asp-Xbb-Gly-Xbb, ahol az Xaa valamilyen hidrofób aminosav maradék, az Xbb pedig szerin vagy threonin (Gagnon-Arsenault és mtsai. 2006). Struktúrájukat tekintve az aszpartil proteinázok „kétkarú” enzimek, ahol egy-egy karon, az aktív centrum árkában találhatók a katalitikus aszparaginsav maradékok. További jellegzetességük, hogy ellentétben a szekretált aszpartil proteinázokkal, a yapszin fehérjék nagy mértékben glikoziláltak. A glikoziláció fehérjétől függően lehet $\mathrm{O}$ és $\mathrm{N}$ jellegű is (Ash és mtsai. 1995, Komano és Fuller 1995, Lipke és Ovalle 1998). A yapszin fehérjékre jellemző, hogy C-terminális végükön glikozilfoszfatidilinozitol (GPI) módosítás játszódik le az érés folyamán, melynek eredményeképpen ezen fehérjék a sejtfalba képesek rögzülni (GagnonArsenault és mtsai. 2006).

Érdekes módon a CUG kládon kívül eső C. glabrata esetén, amely filogenetikailag a Saccharomyces cerevisiae-hez áll közel, más szekretált aszpartil proteinázt nem találunk, csupán yapszin típusú fehérjét (Krysan és mtsai. 2005). C. glabrata esetén tizenegy yapszin fehérjét kódoló gént találunk. Virulenciában betöltött szerepükre utal, hogy J774A.1 makrofág sejtvonallal végzett koinkubáció során az YPS1 és YPS7 gének kivételével az összes többi 
YPS gén jelentősen emelkedett transzkripciós szintet mutatott, összehasonlítva a kontrollként alkalmazott, csak a fagocita sejtek tápközegében nevelt élesztők YPS génjeihez képest. A sejtfal integritásának fenntartásában betöltött szerepükre utal, hogy az yps(1-11)ム deléciós törzs növekedési rátája jóval elmaradt a vad típusú törzs növekedéséhez képest, ozmotikus, valamint sejtfali stresszorok alkalmazása esetén. In vivo egérkísérlet során sikerült kimutatni továbbá, hogy az yps(1-11) $\Delta$ deléciós törzs lényegesen kisebb virulenciával bír, mint a vad típusú törzs (Kaur és mtsai. 2007).

A CUG kládba tartozó Candida fajok körében a C. albicans Sap9 és Sap10 fehérjéit azonosították, mint yapszin-szerü fehérjéket. Ezen fehérjék, hasonlóan a yapszin típusú fehérjékhez szintén C-terminális részükön egy glikozilfoszfatidilinozitol csoport megkötésére képes helyet tartalmaznak. Ezen kívül, ellentétben a többi $C$. albicans Sap fehérjével ez a két fehérje gazdagon N glikozilált, a Sap9 esetén öt, míg a Sap10 esetén tíz ilyen helyet találunk (Albrecht és mtsai. 2006). Ezidáig a CUG kládba tartozó fajok közül csupán a C. albicans ezen két fehérjéje, amely bizonyítottan GPI-kötött fehérje, ezáltal a yapsin fehérjékhez hasonló szerkezetü (Albrecht és mtsai. 2006).

A CUG kládon belül a $C$. albicans-on kívül számos más patogén faj is termel szekretált aszpartil proteinázokat. C. albicans esetén tíz (SAP1-SAP10) szekretált aszpartil proteináz gént találunk, amely egy géncsaládot alkot (Hube és Naglik 2001). Aminosav sorrendjük homológiái alapján a géncsalád kisebb alcsaládokra osztható [SAP1-3, SAP4-6, SAP9-10 (a SAP7 és SAP8 gének divergensek, nem tartoznak egyetlen alcsaládba sem)] (Naglik és mtsai. 2003). A klinikailag releváns nem-albicans fajokban is nagy számban jelen vannak ezen aszpartil proteináz gének ortológjai. C. tropcalis esetén négy (SAPT1-SAPT4), C. dubliniensis esetén nyolc (SAPCD1-SAPCD4, SAPCD7-SAPCD10), valamint C. parapsilosis esetén három (SAPP1-SAPP3) szekretált aszpartil proteináz gént találunk (Pichova és mtsai. 2001, Zaugg és mtsai. 2001). Fontos megjegyezni, hogy az összes klinikailag releváns Candida faj szekretált proteázai egységesen az aszpartil proteinázok családjába tartoznak, szerin, cisztein és metalloproteinázokat nem azonosítottak ezen fajokban (Naglik és mtsai. 2003, Hruskova-Heidingsfeldova 2008).

Minden szekretált aszpartil proteináz fehérje preproenzimként szintetizálódik a durva felszínű endoplazmatikus retikulumban. Ezen a helyen a szignál peptidet egy szignál peptidáz lehasítja. A proenzim ezután transzportálódik a Golgi apparátusba, ahol egy membrán kötött Kex2 nevü proteináz általi hasítással alakul ki az érett fehérje. C. parapsilosis esetén kimutatták, hogy a Sapp1 fehérje aktiválódása a Kex2 fehérje nélkül, autokatalitikusan is végbemehet (Dostal és mtsai. 2005). Miután az érett fehérje kialakult, szekretorikus 
vezikulákba kerül, amely a plazma membránhoz szállítja azt. Itt, amennyiben glikozilfoszfatidilinozitolt köt a fehérje (Sap9, Sap10 esetén), úgy az enzim sejtfalhoz kötötten marad, míg, ha ilyen poszttranszlációs módosítás nem történik, úgy az extracelluláris térbe jut a fehérje (Naglik és mtsai. 2003, Vinterova és mtsai. 2011). Kimutatták, hogy in vitro rendszerben a Sap9 és Sap10 fehérjék képesek a mikroba saját, sejtfalhoz kötött fehérjéinek a hasítására, melyek mind a biofilm képzésben, mind a mikroba sejtfalának szintézisében fontos szerepet játszanak (Schild és mtsai. 2011).

C. parapsilosis esetén kimutatták, hogy a Sapp1 fehérje a sejtfalon történő áthaladás során nem kovalens kötésekkel kötődik a sejtfali komponensekhez, valamint sejtfalhoz asszociált fehérjékhez. Kimutatták továbbá, hogy elsőként az érett fehérje aktív centruma az, amely áthalad a sejtfalon, így a fehérje már a sejtfalhoz asszociáltan is funkcióképes (Vinterova és mtsai. 2011). Candida fajok szekretált aszpartil proteináz izoenzimek mérete 35 és 50 kDa között változik, C. parapsilosis esetén mind a Sapp1, mind a Sapp2 fehérje 37 kDa tömegünek adódott. A szekretált aszpartil proteináz izoenzimek $\mathrm{pH}$ optimuna a savas tartományba esik, amely C. albicans esetén pH 2 és pH 7 közé esik, míg C. parapsilosis esetén mind a Sapp1, mind a Sapp2 izoenzimek pH optimuma 4 körül található (Naglik és mtsai. 2003, Merkerova és mtsai. 2006).

A C. parapsilosis ezidáig három azonosított szekretált aszpartil proteináz szekvenciája (SAPP1-SAPP3) közül kettő fehérje (Sapp1, Sapp2) termeltetése és biokémiai jellemzése történt meg (Dostal és mtsai. 2005, Merkerova és mtsai. 2006, Hruskova-Heidingsfeldova és mtsai. 2009). Az előzőekben leírtak szerint, ezen két fehérje is pre-pro enzim formájában szintetizálódik. In vitro, induktív körülmények között (BSA tartalmú tápközegben) mindkét fehérje termelődése és szekréciója lezajlik, ám a Sapp1 fehérje legalább egy nagyságrenddel nagyobb mennyiségben termelödik, mint a Sapp2 fehérje. Érdekes módon, míg a Sapp1 fehérje termelődése csak külső fehérje forrás hozzáadása során volt megfigyelhető, addig a Sapp2 fehérje termelődése nem induktív körülmények között is jelen volt (HruskovaHeidingsfeldova és mtsai. 2009). Aktiválódásukra ez esetben is igaz, hogy a C. parapsilosis Kex2 szerin proteáz fehérjéje végzi, ám a pro-Sapp1 fehérje analízise során kiderült, hogy ez a fehérje savas körülmények ( $\mathrm{pH}$ 3-4) között autokatalitikus aktiválódásra is képes. Az autokatalitikusan aktiválódott Sapp1 fehérje N-terminálisán egy aminosavval rövidebbnek bizonyult a Kex2 által aktiválódott formához képest, ám ezen csonkolt fehérje proteolitikus aktivitása azonosnak bizonyult a szerin proteáz által aktivált fehérjével. Ezzel szemben a Sapp2 fehérje kizárólag a Kex2 fehérje általi aktiválódásra képes, sem savas környezetben autokatalitikusan, sem a Sapp1 fehérje általi aktiválódásra nem képes (Merkerova és mtsai. 
2006). A jellemzően egy nagyságrenddel nagyobb mennyiségű termelődés mellet, szintetikus peptidek, mint szubsztrátok alkalmazásával kimutatható volt, hogy a Sapp1 fehérje katalitikus aktivitása jóval nagyobb és szubsztrát specifitása szélesebb körü, mint a Sapp2 fehérjének (Hruskova-Heidingsfeldova és mtsai. 2009).

Mára a Sapp1 és Sapp2 fehérjék kristályszerkezete és háromdimenziós szerkezete is elérhetővé vált. A Sapp1 fehérje kristályszerkezetének analízise során a fehérje főleg $\beta$ redős szerkezetet mutatott, melyen belül két domén fog közre egy mélyedést, amely a szubsztrát befogadására képes. Minden domén tartalmaz egy katalitikus aszparaginsav helyet, melyek jellemzően DTG (Aszparaginsav-Treonin-Glicin aminosav hármas), vagy DSG (Aszparaginsav-Szerin-Glicin aminosav hármas) motívumok részeként vannak jelen. Az aktív centrum három „entrance loop” szerkezetet tartalmaz, amely jellemzően más Sap izoenzimek struktúrájának is része (Dostal és mtsai. 2009, Abad-Zapatero és mtsai. 1996). Bár a Sapp1 és Sapp2 fehérjék aminosav sorrendje nagyfokú homológiát mutat, a strukturális modellek összehasonlítása azonban jelentős mértékü eltéréseket fedett fel. Sapp2 fehérje esetén egy négy aminosavnyi inszerció figyelhető meg a Sapp1 fehérjéhez képest a 293.-296. aminosavak esetén, amely egyedi eset aszpartil proteinázok esetén. A négy aminosavnyi inszerció változatos szerveződéseket tesz lehetővé az enzim szerkezetében, melyek az aktív centrumot is érinthetik. Egy arginin inszerciója figyelhető meg a Sapp2 esetén a 75. pozícióban, amely az aktív centrumot elfedő rész bázisánál helyezkedik el. Az ily módon kibővült fedő rész és az előbb említett négy aminosavnyi inszerció jelenléte nagymértékben befolyásolhatja az enzim aktív centrumának hozzáférhetőségét (Hruskova-Heidingsfeldova és mtsai. 2009).

A szekretált aszpartil proteinázok termelése és Candida fajok virulenciája közt korreláció fedezhető fel. A C. albicans, C. tropicails és $C$. parapsilosis fajok in vitro jóval több proteinázt termelnek, mint a klinikailag kevéssé jelentős fajok, például a $C$. kefyr vagy a C. guillermondii, (Macdonald és Odds 1983, Gácser és mtsai. 2007a). Számos Candida faj genomjában találhatunk aszpartil proteináz géneket. Monod és munkatársai (1994) a $C$. albicans SAP1 génjét, mint jelölt próbát alkalmazva EcoRI emésztett C. guillermondii genomi DNS-én végzett RFLP analízise alapján négy fragmentumot azonosított, habár in vitro BSA tartalmú tápközegben proteináz termelés nem volt kimutatható (Monod és mtsai. 1994). A szekretált aszpartil proteinázok virulenciában betöltött szerepéről a legtöbb információ $C$. albicans-on végzett vizsgálatokból áll rendelkezésünkre. 
A szekretált aszpartil proteinázok virulenciában betöltött szerepe C. albicans-ban régóta tanulmányozott, munkánk kezdetén a $C$. parapsilosis szekretált aszpartil proteinázok virulenciában betöltött szerepéről minimális információ állt rendelkezésünkre.

Több tanulmány is beszámolt arról, hogy C. albicans által okozott vaginális kandidiázisban szenvedő betegekről izolált törzsek proteináz termelése kétszerese volt, a tünet nélküli C. albicans-t hordozó egyénekről izolált törzsekkel összehasonlítva (Agatensi és mtsai. 1991, De Bernardis és mtsai. 1990). Egy másik tanulmány szerint 21, vaginitiszben szenvedő, HIV pozitív, női páciensből származó izolátumok négyszer nagyobb mennyiségű Sap fehérjét termeltek, mint 7 HIV pozitív, ám vaginitiszben nem szenvedő, vagy 31 HIV negatív, de kandidiális vaginitiszben szenvedő paciensből származó izolátumok (De Bernardis és mtsai. 1999).

A C. albicans faj tíz $S A P$ génje az élesző életciklusától, valamint a fertőzés heyétől és súlyosságától függően meghatározott rendben expresszálódik (Hube 1998). Induktív körülmények közt a $S A P 2$ gén mutatja a legnagyobb mértékü expressziót, míg a $S A P 1$ és SAP3 gének, hasonlóan a SAP4-SAP6 alcsaládhoz, az élesztő - hifa átmenete során mutatnak magas szintű expressziót. A $S A P 7$ és $S A P 8$ gének jellemzően hőmérséklet által regulált gének. A $S A P 9$ és $S A P 10$ gének konstitutívan expresszálódnak csaknem minden környezeti viszony esetén, mind a mikroba élesztő, mind hifa alakjában (Naglik és mtsai. 2003). Rekonstruált humán epitéliális modell esetén Schaller és munkatársai kimutatták, hogy a fertőzés során a $S A P$ gének expressziója szorosan koordinált (SAP1, SAP3 >SAP6 > SAP2 > SAP8). Ezesetben a Sap4, Sap5 és Sap6 termelődése nem okozott szöveti károsodást (Schaller és mtsai. 1999). A Sap2 fehérje a C. albicans által legnagyobb mennyiségben szekretált aszpartil proteináz. A fehérjéről kimutatták, hogy számos, gazdaszervezet által termelt antimikrobiális fehérje bontására képes. Ezen fehérjék közt találjuk a mucint, amely a száj nyálkahátya felszínét védi, valamint a szekretorikus IgA fehérjét (Colina és mtsai. 1996, Ruchel 1986). Összevetve más típusú immunglobulinokkal, az IgA jóval rezisztensebb proteolitikus emésztésekkel szemben, valamint a szekretorikus IgA számos toxint és enzimet képes semlegesíteni. A C. albicans Sap2 fehérjéje képes az IgA bontására, ezáltal elősegítve a mikroba bukkális epiteliális sejtekhez való tapadását, valamint terjedését (Kilian és mtsai. 1988). Morschhauser és munkatársai kimutatták, hogy a C. albicans proteinázok képesek voltak elbontani egy humán endotheliális sejtvonal mind szolubilis, mind az immobilizált extracelluláris mátrix proteinjeit, amely eredmény arra enged következtetni, hogy ezen fehérjék elősegítik a C. albicans disszeminációját (Morschhauser és mtsai. 1997). Ezen túlmenően a $C$. albicans Sap fehérjék, széles szubsztrátspecificitásuknak köszönhetően 
eredményesen bontják a gazdaszervezet antimikrobiális fehérjéit, mint például a laktoferrint, laktoperoxidázt, katepszin D fehérjét, valamint a komplement rendszer komponenseit (Gropp és mtsai. 2009). Egy tanulmány felhívja a figyelmet a proinflammatorikus interleukin-1 $\beta$ prekurzorából történő aktiválódására, a C. albicans Sap2 hatására. Ez az eredmény azt mutatja, hogy a Sap2 fehérjének szerepe van a gyulladásos válasz kialakulásában és fenntartásában (Beausejour és mtsai. 1998).

Számos tanulmány vizsgálta $C$. albicans esetén a szekretált aszpartil proteinázok, valamint egyéb virulenciafaktorok közti kapcsolatot. Már egy korai tanulmány kimutatta, hogy in vitro rendszerben epitéliális sejtekhez tapadt élesztő sejtek jóval nagyobb proteináz termelést mutattak az epitéliális sejtekhez nem kitapadt élesztő sejtekkel összevetve (Ghannoum és Abu Elteen 1986). C. parapsilosis esetén in vitro humán epitéliális modellt alkalmazva szintén sikerült igazolni a $S A P P$ gének nagyobb mértékű expresszióját az epitéliális szövethez tapadt élesztő sejtek esetén (Silva és mtsai. 2009).

Régóta tudott, hogy szoros korreláció áll fenn C. albicans esetén a SAP4 és SAP6 gének expressziója és a mikroba élesztő - hifa átmenete között (Hube 1998). A SAP4 és SAP6 gének promóter régiójának analízise során a Tecl transzkripciós faktor kötőhelyének konszenzus szekvenciáját fedezték fel [CATTC(A/C)] (Schweizer és mtsai. 2000). A homozigóta deléciós $\Delta / \Delta t e c 1 C$. albicans mutáns törzs esetén kimutatták, hogy a törzs hifa képzésre és a SAP4 és SAP6 gének expressziójára in vivo egyaránt képtelen, amely eredmény azt támasztja alá, hogy a hifa képzés valamint a proteináz termelés között szoros összefüggés áll fenn, azok útvonalai szorosan kapcsoltak. A kapcsolt útvonal koncepcióját további tanulmányok is alátámasztották (Schroppel és mtsai. 2000, Felk és mtsai. 2002). A $\Delta / \Delta c p p 1$ (egy mitogén aktivált protein kináz foszfatáz) deléciós mutáns törzs hiperfilamentációs fenotípust, valamint megnövekedett SAP4 és SAP6 expressziót mutatott (Schroppel és mtsai. 2000). További bizonyítékul szolgált, hogy rágcsáló szisztémás peritoneális modellt alkalmazva a $\Delta / \Delta e f g 1$ törzs jóval kisebb mértékü hifa képzést és SAP4, SAP6 expressziót mutatott, valamint ebből kifolyólag jóval kevésbé volt képes károsítani a parenhimális szerveket (Felk és mtsai. 2002). Érdekes módon, a $\Delta / \Delta$ sap4- $\Delta / \Delta$ sap5- $\Delta / \Delta$ sap6 deléciós törzs esetén szisztémás modellben csökkent inváziós képességet tapasztaltak, ám ezen törzs hifa képzésre képes volt. A SAP5 gén expressziója nem függött a hifa képzéstől, ám a két fö hifaképzéshez szükséges fehérje jelenléte (Cph1 és Efg1) szükséges volt a SAP5 gén expressziójához (Staib és mtsai. 2002). Összességében ezen vizsgálatok azt mutatják, hogy nem csak a proteináz termelés és a hifaképzés szabályozása mutat szoros korrelációt, hanem a C. albicans hifasejteknek szükségük van a proteináz termelésre, annak érdekében, hogy a 
mikroba invazívvá váljon in vivo. A C. albicans WO-1 törzse esetén a white - opaque átmenet vizsgálata kimutatta, hogy ezen átmenet számos celluláris változás eredménye, melyek érintik a proteináz termelést is (Soll 1992). Ezzel egyidőben kimutatták, hogy mind a WO-1, mind a C. albicans 3153A jelü törzsek fenotipikus változása és proteáz termelése között kapcsolat van (Morrow és mtsai. 1994, Morrow és mtsai. 1993). Mindkét törzs esetén a SAP1 expressziója nagymértékü növekedést mutatott a fenotipikus váltás során, míg a $S A P 2$ gén aktiválódását mindkét stádiumban megfigyelték, ám csupán exogén protein hozzáadása során.

Számos tanulmány vizsgálta a Sap fehérjék által kiváltott immunglobulin termelést. Macdonald és Odds voltak az elsők, akik proteináz - specifikus IgG antitest termelését mutatták ki szisztémás candidiasis során (Macdonald és Odds 1980). Száj-garatüregi kandidiázisban szenvedő HIV pozitív paciensek esetén, emelkedett mennyiségü Sap1, Sap2 és Sap6 ellen termelődött IgA antitest volt detektálható, a HIV pozitív, de kandidiázisban nem szenvedő, valamint a teljesen egészséges kontroll csoportokkal összevetve (Drobacheff és mtsai. 2001). De Bernardis és munkatársai rágcsáló vaginitisz modell esetén beszámoltak arról, hogy a $C$. albicans Sap2 elleni immunizálás, vagy a fehérje ellen termeltetett monoklonális antitest alkalmazása részben meggátolta a kandidiális vaginitisz kialakulását (De Bernardis és mtsai. 1996). Ez volt a legelső eset, melyben kimutatták az anti-Sap antitestek védő hatását.

A C. albicans által termelt proteinázok elleni lehetséges védekezés lehet bizonyos proteináz inhibitorok használata. Colina és munkatársai voltak az elsők, akik kimutatták, hogy a mucin Sap proteinázok általi degradációja in vivo gátlódik pepstatin jelenlétében (Colina és mtsai. 1996). Humán epitéliális sejtvonal által termelt szolubilis, valamint immobilizált fehérjék Sap fehérjék általi bontását in vitro szintén sikerült gátolni pepsztatint alkalmazva (Morschhauser és mtsai. 1997). In vivo egér peritonitisz modellben $1 \mathrm{mg} / \mathrm{kg}$ koncentrációban alkalmazott pepsztatin adagolása szignifikánsan csökkentette a lép és hasnyálmirigy szöveti károsodását (Kretschmar és mtsai. 1999). Ezzel szemben, in vivo intravénás egér modell fertőzése során a pepsztatin alkalmazása nem vátott ki ilyen jellegü védő hatást (Fallon és mtsai. 1997), amely arra enged következtetni, hogy bár a fertőzés kezdeti stádiumában pepsztatin alkalmazása eredményesen gátolja a mikroba kolonizációját, ám a mikroba terjedését meggátolni már nem képes. Ugyanezen tanulmány, $S A P$ génekre deléciós törzsek alkalmazásával kiderítette, hogy a pepstatin a Sap4, Sap5 és Sap6 fehérjék gátlása által fejti ki a hatását. 
C. parapsilosis, C. orthopsilosis és C. metapsilosis in vitro rekonstruált humán epitéliális szöveti fertőzés esetén pepstatin A alkalmazása során szintén kisebb mértékü szöveti károsodás volt megfigyelhető (Gácser és mtsai. 2007a).

A HIV vírus által termelt proteináz szintén az aszpartil proteázok közé tartozik, így a pepstatin A proteináz inhibitoron kívül a HIV proteinázok inhibitorait is vizsgálták, mint lehetséges terápiás szereket. Négy HIV proteináz inhibitor (ritonavir, saquinavir, indinavir és nelfinavir) vizsgálata során a ritonavir bizonyult a legeredményesebb C. albicans Sap2 proteáz inhibitornak $\left(\mathrm{K}_{\mathrm{i}}=0,34 \mu \mathrm{M}\right)$ (Borg-von Zepelin és mtsai. 1998). A négy proteináz inhibitor közül csak a ritonavir és a saquinavir volt képes gátolni a $C$. lusitaniae-ból, $C$. parapsilosis-ból C. tropicalis-ból és a C. albicans-ból tisztított Sap proteázok aktivitását (Pichova és mtsai. 2001). In vitro rekonstruált humán epitéliális modellt alkalmazva a saquinavir képes volt a $C$. albicans által okozott szöveti károsodást mérsékelni (Korting és mtsai. 1999), míg in vivo patkány vaginitisz modellt alkalmazva a ritonavir és indinavir a flukonazollal összevethető mértékű antifungális hatás kiváltására volt képes (Cassone és mtsai. 1999).

In vivo egér kísérletben a Sap2 alkalmazása akár intakt, akár denaturált formában védő hatást váltott ki intraperitoneális $C$. albicans fertőzés esetén. Minden esetben megfigyelhető volt a szérumban jelenlévő anti-Sap2 antitest, valamint annak passzív transzportja nagymértékben képes volt csökkenteni a gomba által vesében okozott gyulladást (Vilanova és mtsai. 2004).

Mindezen adatok rámutatnak, hogy a szekretált aszpartil proteinázok jelentős szerepet játszanak a $C$. albicans virulenciájában. $C$. parapsilosis esetén ezen proteinázok virulenciában betöltött szerepe kevéssé ismert. Ennek egyik oka, hogy míg C. albicans esetén a knock-out és overexpressziós mutáns törzsek létrehozása régóta megoldott, addig C. parapsilosis esetén ezen eszköztár napjainkban is kidolgozás alatt áll.

\subsection{Gén deléciós és over-expressziós módszerek Candida fajokban}

A C. albicans és a nem-albicans Candida fajok többsége diploid organizmus, melyek nem rendelkeznek szexuális ciklussal. A diploid jelleg miatt a molekuláris genetikai markerek alkalmazása hosszú ideig nehézséget jelentett ezen fajok esetében (Papon és mtsai. 2012). Candida fajok esetén két nagy csoportja alkalmazható a szelekciót biztosító géneknek, amelyek genetikai módosítások kivitelezését teszik lehetővé. A két nagy csoport az auxotrófia markerek, valamint a drog rezisztencia kazetták alkalmazása. 
Auxotrófia markerek alkalmazása. Annak érdekében, hogy az auxotrófia markerek alkalmazása lehetővé váljon élesztő fajok esetén, elsőként ezen élesztő fajok auxotróf törzseinek izolálása, valamint komplementációs analízise és metabolikus útvonalainak feltérképezése történt meg (Kakar és Magee 1982). Az izolált auxotróf törzs esetén a az auxotrófiát komplementáló enzim génjének alkalmazása használható, mint szelekciós marker. C. albicans esetén számos megfigyelés a BWP17 tripla auxotróf (his1, arg4, ura3) törzshöz köthető, amelynél a HIS1, ARG4 és URA3 vad típusú gének, mint szelekciós markerek alkalmazhatók (Wilson és mtsai. 1999, Samaranayake és Hanes 2011). Az 5-fluoroorotsav alkalmazása, amely prototróf törzsekre toxikus hatású, lehetőséget teremtett az URA3 mediált transzformációs rendszer („URA Blaster” rendszer) kidolgozására, melynek alkalmazásával számos, homozigóta deléciós mutáns törzs létrehozása és azok fenotipikus jellemzése lehetségessé vált. Az „URA Blaster” konstrukciónak sok változatát kidolgozták. A transzformálandó törzs ezen rendszer esetén a $C$. albicans uracil auxotróf törzse. Az elsőként kidolgozott konstrukció az URA3 marker upstream és downstream végén a Salmonella typhimurium-ból származó hisG direkt ismétlődéseket tartalmazta, amely lehetővé tette az URA3 gén integráció utáni spontán rekombináció útján történő kivágódását. Az 5-fluoroororát alkalmazásával lehetővé vált a vad típusú URA3 gén kontraszelekciója (Noble és Johnson 2007, Fonzi és Irwin 1993) (3. ábra).

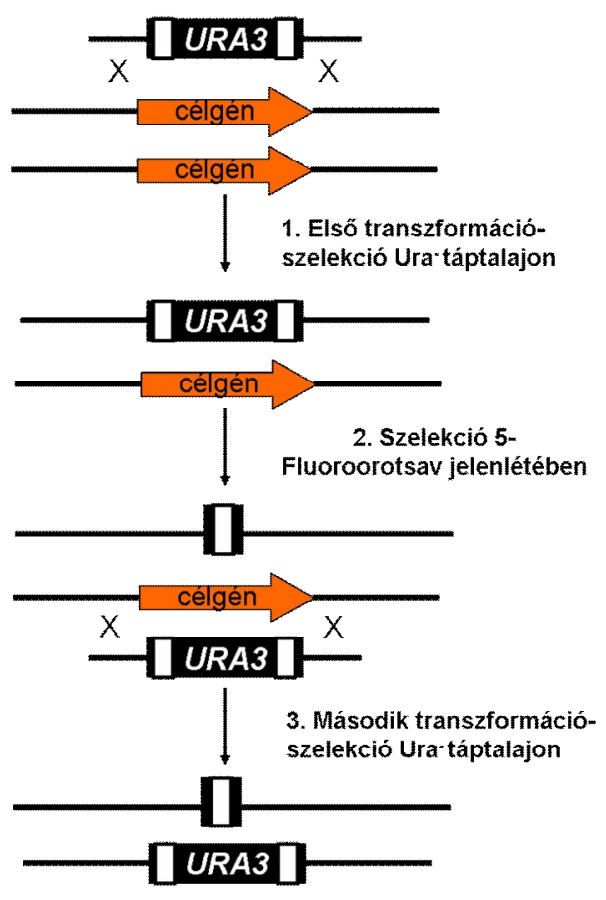

3. ábra

Az „URA Blaster” rendszer müködése. (Fonzi és Irwin 1993 alapján). 
Egy későbbiekben kidolgozott deléciós konstrukció az URA3 marker gén mellet a C. albicans SAP2 gén promotere által szabályozott caFLP rekombináz gént tartalmazta, amely a domináns szelekciós markert alkalmazó nourseothricin kazettához hasonlóan prototróf deléciós mutáns törzsek létrehozását tette lehetővé. A konstrukció használatával sikeresen létrehozták a $C$. albicans $\Delta / \Delta c d r 1$ és $\Delta / \Delta m d r 1$ homozigóta deléciós törzseit (Morschhauser és mtsai. 1999, Staib és mtsai. 2000). Szintén C. albicans-ban homozigóta deléciós mutánsok rövid időn belüli létrehozását tette lehetővé egy kettős auxotrófiát komplementáló rendszer alkalmazása (Noble és Johnson 2007, Noble és Johnson 2005), (4. ábra).

\section{Első allél deléciója}

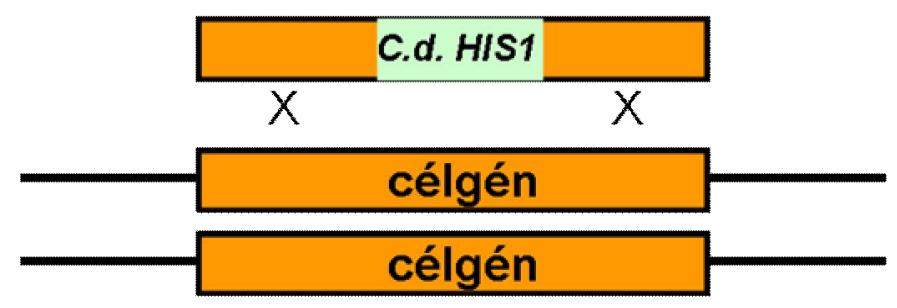

\section{Második allél deléciója}

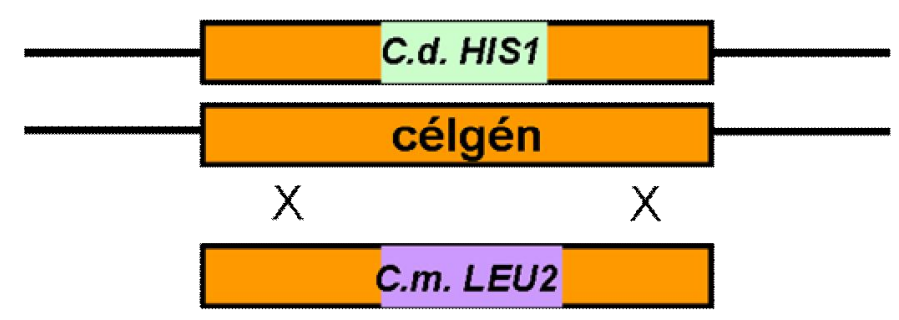

4. ábra

C. albicans-ban kidolgozott géndeléciós módszer kettős auxotrófia marker (HIS1, LEU2) alkalmazásával. (Noble és Johnson 2005 alapján).

Ez esetben kiindulási törzsként egy kettős, hisztidin és leucin auxotrófia markert hordozó $C$. albicans izolátum szolgál. A célzott gén deléciója során a két allél kiütésével egyidejűleg az auxotrófia markerek komplementációja is megtörténik: a hisztidin auxotrófia marker komplementációja C. dubliniensis HIS1, a leucin auxotrófia marker komplementációja pedig C. maltosa LEU2 gén bevitelével történik. C. parapsilosis esetén szintén hasonló metódussal sikeresen végrehajtottak géndeléciót (Connolly és mtsai. 2013).

Hygromycin B rezisztencia marker. Az elsőként alkalmazott domináns szelekciós marker, melyet Candida fajokban alkalmaztak a hygromycin B rezisztencia marker (HPH) volt (Hara és mtsai. 2000). Az alkalmazott bakteriális hph ORF-ben elsőként a kilenc CTG kodont módosították CTC kodonná. A markert elsőként $C$. tropicalis-ban alkalmazták. Ennek érdekében a módosított hygromycin $\mathrm{B}$ gén expresszióját a $C$. tropicalis foszfoglicerát-kináz 
$(P G K)$ génjének szabályozó régiójával végezték. Egy évvel később ezt a konstrukciót alkalmazva C. tropicalis-ban létrehozták a homozigóta ura3 deléciós mutánst (Hara és mtsai. 2001). C. albicans esetén a bakteriális $h p h$ gén kilenc CTG kodonját egyéb, leucint kódoló kodonra módosították, valamint a $C$. albicans kodon felhasználási preferenciájának megfelelően egyéb módosításokat is végrehajtottak. A módosított szekvenciát a $C$. albicans TEF2 promotere és $A C T 1$ terminátor régiója közé klónozták. Az így kapott konstrukció segítségével számos C. albicans izolátum transzformációját sikeresen végrehajtották (Basso és mtsai. 2010). Millerioux és munkatársai az eredeti, 2001-ben elkészített $H P H$ marker segítségével sikeres transzformációt hajtottak végre $C$. guillermondii izolátumokon (Millerioux és mtsai. 2011). A Candida fajok többsége bár szenzitívnek bizonyul a hygromycin B-vel szemben, ám csupán magas koncentráció (400-1000 $\mu \mathrm{g} / \mathrm{ml}$ ) esetén (Papon és mtsai. 2012).

Phleomycin/zeocin rezisztencia marker. Ezen rezisztencia marker Candida fajokra optimalizálása és alkalmazása 2003-ban történt meg (Tang és mtsai. 2003). A Streptoalloteichus hindustanus ble génje, amely egy glioxiláz fehérjét kódol, rezisztenciát biztosít a bleomycin/phleomycin/zeocin antibiotikum csoporttal szemben. Az optimalizálás során az öt CTG kodont ebben az esetben is más, leucint kódoló tripletekre cserélték. $C$. rugosa-ba való transzformálást követően a marker gént sikeresen expresszáltatták $S$. cerevisiae-böl származó GAL1 és TEF1 gének promotereinek vagy a C. rugosa LIP3 promoterének segítségével. A Stapylococcus aureus (MRSA) 252 ble génje nem tartalmaz CTG kodont. Ezen markert alkalmazva Dmytruk és munkatársai sikeres transzformációt hajtottak végre $C$. famata esetén (Dmytruk és mtsai. 2011). A transzformáló konstrukció a ble gén mellett a C. famata TEF1 génjének promoterét tartalmazta. Bár a Candida fajok általánosságban szenzitívnek bizonyulnak a bleomycin/phleomycin/zeocin antibiotikum csoporttal szemben, mégis nagy számban fordul elő spontán rezisztencia kialakulása ezen antibiotikum csoporttal szemben (Papon és mtsai. 2012).

Mikofenolsav rezisztencia marker. A $C$. albicans inozin 5'-monofoszfát dehidrogenázt kódoló IMH3 génjét C. albicans-ban túlmüködtetve mikofenolsav rezisztenciát sikerült kiváltani (Kohler és mtsai. 1997). A markert eredményesen alkalmazták, mint riporter gént C. albicans-ban stádium specifikusan kifejeződő virulencia faktorok, valamint witheopaque fenotípus váltás vizsgálatához (Staib és mtsai. 2000, Strauss és mtsai. 2001). Helyspecifikus rekombinázzal való kombinációban géndeléció létrehozásához is sikeresen felhasználták a markert (Morschhauser és mtsai. 2005). Az elmúlt évtized során ezzel a 
domináns szelekciós markerrel transzformáltak más Candida fajokat is (Gácser és mtsai. 2005, Kosa és mtsai. 2007).

Nourseotricin rezisztencia marker. Az E. coli sat1 génje, amely sztreptotricin aciltranszferázt kódol, rezisztenciát biztosít a nourseothricinnel szemben. Ebben az esetben a CTG kodonokat CTT kodonokkal helyettesítették. A módosított CaSATl szekvenciát sikeresen expresszáltatták $C$. albicans-ban, annak ACT1 promoterét és $P C K 1$ terminátorát alkalmazva (Roemer és mtsai. 2003). Egy évvel később, ezen optimalizált szekvenciának egy másik változatát is kidolgozták, ahol a $C$. albicans $A C T 1$ promoter és URA3 terminátor szekvenciáját alkalmazták (caSAT1) (Reuss és mtsai. 2004). Ugyanezen munka során a caSAT1 marker flipper variánsát is kidolgozták, lehetőséget nyitva több gén deléciójához, ugyanabban az organizmusban (5. ábra).

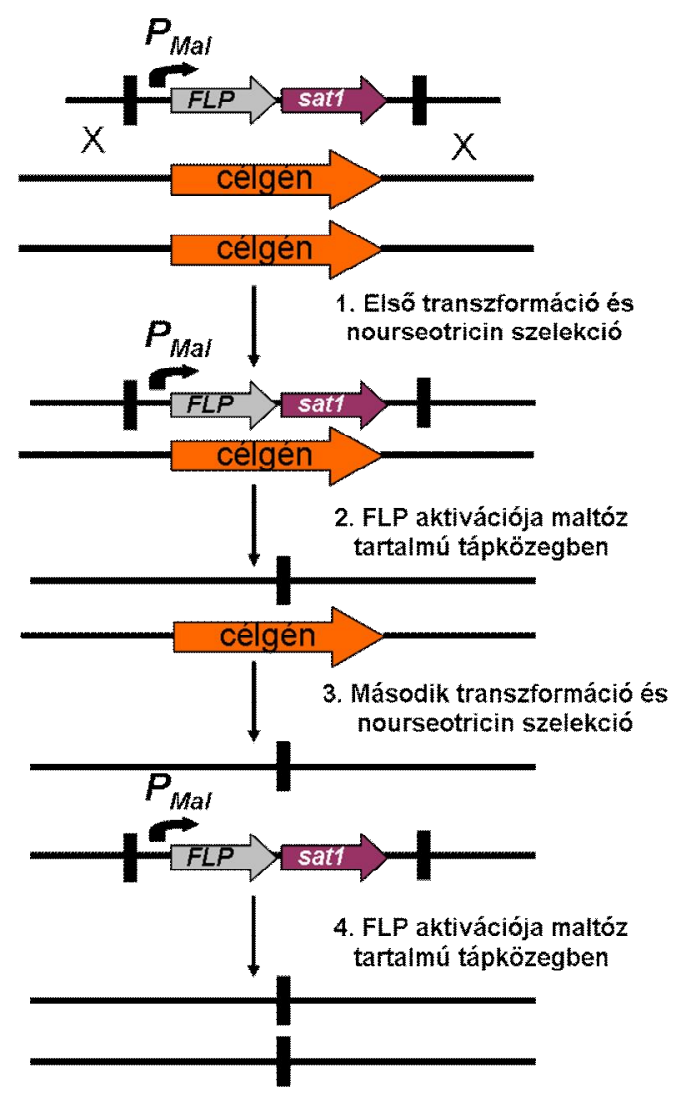

5. ábra

A caSAT1 flipper rendszer müködése (Reuss és mtsai. 2004, Noble és Johnson 2007 alapján).

A caSAT1 flipper rendszer esetén a domináns szelekciós marker helyspecifikus rekombinázok segítségével eliminálhatóvá válik. A konstrukció az FLP rekombináz gént tartalmazza, amely egy indukálható maltóz (MAL2) promoter szabályozása alatt áll. A nourseothricin rezisztens transzformánsok analízise után, maltóz tartalmú tápközegben az Flp helyspecifikus rekombináz képes az FRT helyeket felismerni, majd ezeknél fogva az idegen DNS-t a 
genomból kivágni, így egy transzformációs kör után újra prototróf organizmushoz juthatunk. Bár C. albicans esetén jól müködő géndeléciós eljárások régóta rendelkezésre álltak (Fonzi és Irwin 1993), C. parapsilosis esetén az első sikeres gén deléciót több, mint tíz évvel később a caSAT1 flipper rendszer segítségével hajtották végre (Gácser és mtsai. 2007c).

Tetraciklin által regulált elemek. A tetraciklin által regulált TetR/tetO rendszer eredményes rendszernek bizonyult a génexpresszió kontrollálására prokariotákban és eukariotákban egyaránt. Eredetileg az E. coli-ban kidolgozott TetR/tetO rendszer két komponensböl épül fel. Az első komponens a TetR transzaktivátor elem, míg a második a tetO operátor régió, amely a tetraciklin rezisztencia gének promoteréből származik. Tetraciklin hiányában a TetR fehérje a tetraciklin operátor tet $O$ régióhoz köt, ezáltal meggátolva a fúzionáltatott tetraciklin rezisztens gének kifejeződését. Tetraciklin jelenlétében az antibiotikum a TetR represszorhoz köt és előidézi a disszociációját az operátor régióról (Gossen és mtsai. 1993).

Az első, Candida fajokra adaptált, tetraciklin által regulált rendszer kidolgozása 2000ben történt meg (Nakayama és mtsai. 2000). A kidolgozott rendszer „TET-OFF” néven vonult be a köztudatba. A rendszer az E. coli-ban kidolgozott, majd Candida fajokra optimalizált TetR elemet tartalmazza, amelyet a Hap4 transzkripciós aktivátor transzaktivátor doménjével (tTA), valamint a TR promoterrel fúzionáltattak. A TR promoter élesztő minimál promotert, valamint a tetraciklin operátor régiót $($ tet $O)$ tartalmazza,. A fúzionáltatott transzaktivátor elem (tTA) négy CTG kodonját ez esetben más leucint kódoló tripletre cserélték. Ebben a rendszerben, tetraciklin hiánya esetén a tTA transzaktivátor a tetO régióhoz köt, amely lehetővé teszi a vizsgált gén átíródását. A tetraciklin jelenléte meggátolja a tTA kötődését a tetO operátor régióhoz, így a vizsgált gén expressziója is megszünik. A rendszer alkalmazása eredményesnek bizonyult olyan esszenciális gének tanulmányozásához, melyek deléciója nem volt megvalósítható (Yang és mtsai. 2006).

A második, Candida fajokban alkalmazott, tetraciklin által regulált rendszer a „TETON" rendszer (Park és Morschhauser 2005). A rendszer egy reverz, tetraciklin által szabályozott transzaktivátor elemet ( $\operatorname{cartTA})$, és a Ptet promotert tartalmazza. A kodon módosított cartTA elem a carTetR szekvenciát, valamint a $S$. cerevisiae Gal4 aktivátor doménjét tartalmazza. A carTetR szekvencia a TetR gén kodon módosításából származik, melynek során öt aminosav cseréjére került sor annak érdekében, hogy a tetraciklin által kiváltott hatás ellenkező legyen (Urlinger és mtsai. 2000). A Ptet promoter szekvencia a $C$. albicans $O P 4$ génjének minimális promoter szekvenciáját, valamint a tetO operátor régiót 
tartalmazza. Ebben a rendszerben az adott célgén kifejeződése tetraciklin adása során indukálható.

Gén overexpressziós stratégia. Tekintve, hogy a CUG kládba tartozó fajok többsége diploid, szexuális ciklussal nem rendelkező organizmus, egy gén kiütéséhez legalább két transzformálási lépés szükséges, így ez a metódus sok esetben jelentős időt vesz igénybe. Bár az elmúlt évtized során számos Candida faj heterozigóta és homozigóta deléciós mutáns törzse készült el, melyek gazdag forrást biztosítanak ezen fajok genetikai, sejtbiológiai és virulencia tanulmányozása során (Noble és Johnson 2007, Gácser és mtsai. 2007c), ám sok esetben, főleg virulencia faktorokat kódoló gének esetén nem egyéni gének, hanem géncsaládok, vagy több kópiában is előforduló gének vannak jelen a genomban. A funkcionális redundancia miatt egy gén kiütése nem feltétlenül vált ki mérhető fenotipikus változást (Chauvel és mtsai. 2012). S. cerevisiae esetén a knock out és az overexpressziós mutáns könyvtárak együttes alkalmazása új szignalizációs utak felderítéséhez vezetett (Jin. 2008). Candida fajokban ezidáig C. albicans-ban hajtottak végre sikeres gén túlmüködtetést. Fu és munkatársai (2008) egy 26 törzsből álló overexpressziós kollekciót hoztak létre, melynek során a célzott gén elé tetraciklin által regulált promotert építettek. Az elkészített overexpressziós mutánsok felhasználásával GPI-vel kihorgonyzott fehérjék szerepét tanulmányozták, melynek során az IFF4 gén által kódolt fehérje szerepét azonosították, mint fontos faktort a mikroba megtapadása során (Fu és mtsai. 2008). Sahni és munkatársai egy 103 transzkripciós faktort magába foglaló overexpressziós könyvtárat hoztak létre $C$. albicans-ban (Sahni és mtsai. 2010). Az overexpressziós könyvtár létrehozásához tetraciklin indukálható promotert alkalmaztak. A promoterrel fúzionáltatott célgént a C. albicans ADH1 lokuszába integrálták. C. albicans-ban a legújabban kidolgozott overexpressziós stratégia kidolgozása során egy újonnan kidolgozott klónozási stratégiát, a Gateway klónozást alkalmazták (Chauvel és mtsai. 2012).

A Gateway klónozás során, ellentétben a hagyományos klónozási lépésekkel a vektorba való integráció helyspecifikus rekombinációval történik. Első lépésként a felszaporított ORF-ek „entry” vektorba való integrációja történik, majd egy második hasonló elven alapuló klónozási lépéssel kerül az ORF egy felhasználásra alkalmas „destination” vektorba. Míg az „entry” vektor csupán a kívánt ORF klónozására szolgál, addig a „destination” vektor a tényleges felhasználást szolgálja, így felépítése a felhasználási területtől függően sokféle lehet (Cabral és mtsai. 2012). Chauvel és munkatársai két „destination” vektort dolgoztak ki $C$.

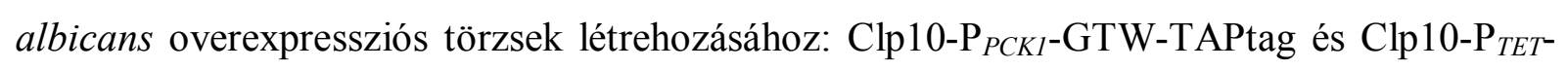
GTW (6. ábra). 
A

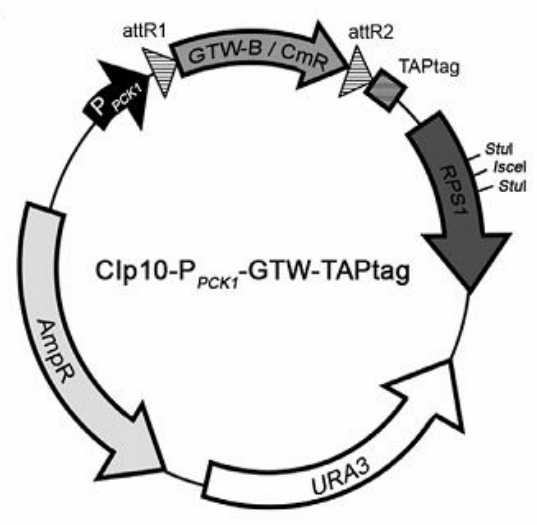

B

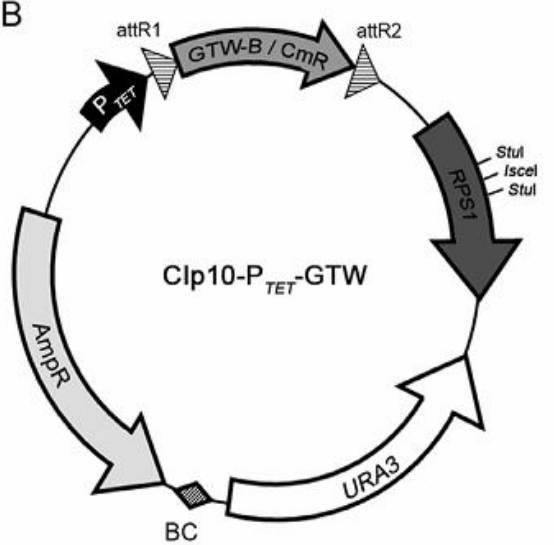

6. ábra

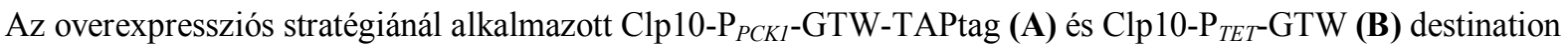
vektorok (Chauvel és mtsai. 2012).

Mindkét vektor alapját a $C$. albicans-ban használt Clp10 integratív vektor képezi (Murad és mtsai. 2000). A Clp10-P $P_{P C K 1}$-GTW-TAPtag vektor egy Gateway kazettát tartalmaz, amelytől 5' irányban a $C$. albicans glükoneogenezis által szabályozott $P C K 1$ gén promotere helyezkedik el. A Gateway kazettát követően a vektoron a leolvasási keretet megtartva a TAPtag helyezkedik el, amely a túlmüködtetett gén termékének affinitás kromatográfiás tisztítását teszi lehetővé. $\mathrm{A}_{\mathrm{P}_{P C K l}}$ promoter glükóz jelenlétében represszálva van, indukciója kazein hidrolíziséből származó aminosav keverékkel (kazaminosav) lehetséges. A Clp10$\mathrm{P}_{T E T}$-GTW vektor egy tetraciklin indukálható promotert tartalmaz. Az overexpressziós könyvtár létrehozásához a szerzők uracil auxotróf törzset használtak, így az auxotrófia komplementálásához mindkét vektor URA3 markert hordoz. Az integrációt a $C$. albicans $R P 10$ lokuszában hajtották végre (7. ábra).

Chauvel és munkatársai munkája során olyan transzkripciós faktorok kerültek túlmüködtetésre, melyek a morfogenezisért és növekedési rátáért felelnek. Számos olyan túlműködtetett gént azonosítottak, melyek a morfogenezis szabályozásában vesznek részt és overexpressziós törzseik meghatározott fenotípust mutattak, ellentétben ezen génekre homozigóta deléciós párjaikkal. Ez az eredmény jól mutatja, hogy az overexpressziós mutáns törzsek és megfelelő deléciós mutációval rendelkező párjaik együttes használata eredményesen használható a mikroba regulációs hálózatainak tanulmányozásához. 


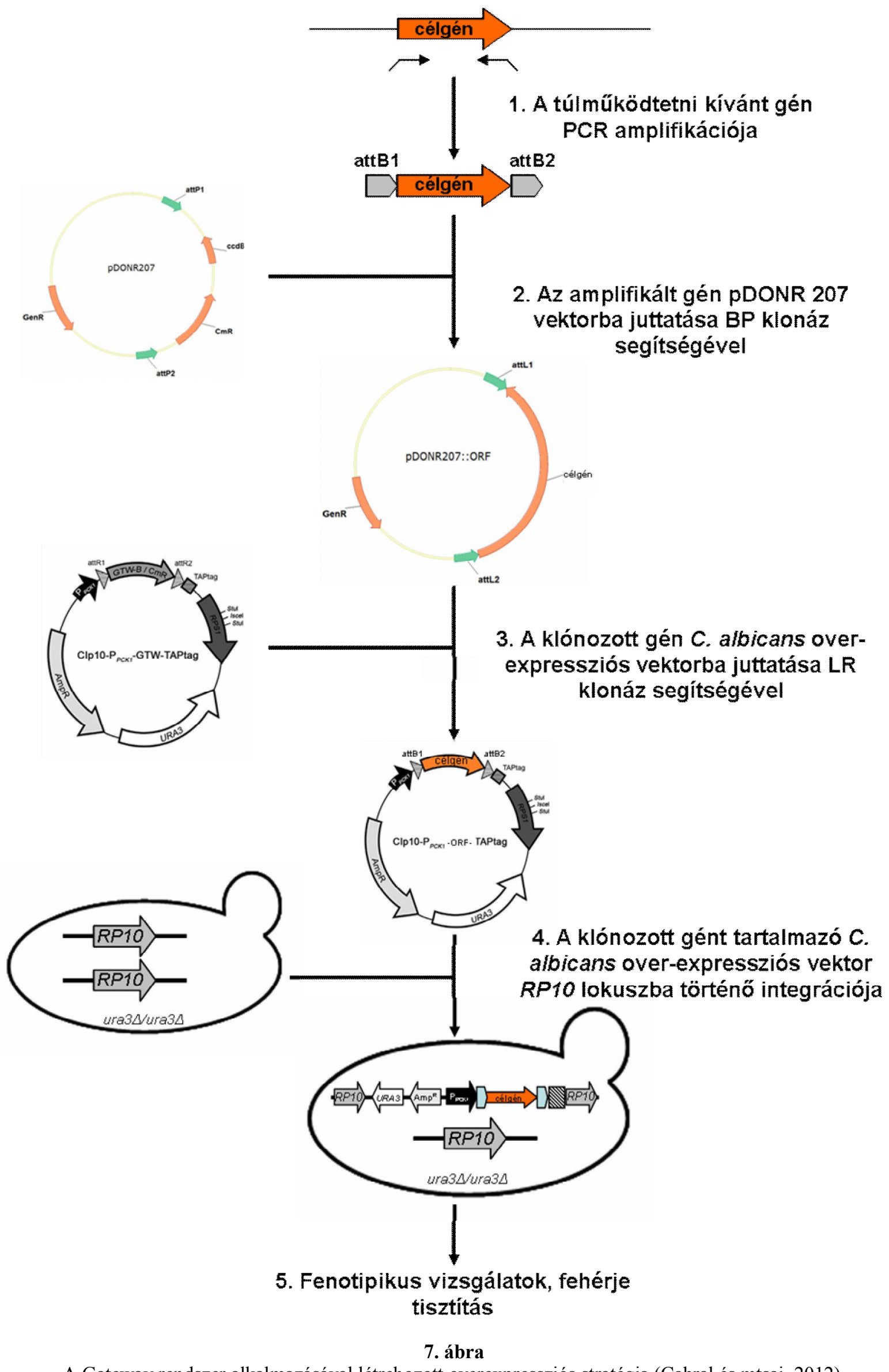

A Gateway rendszer alkalmazásával létrehozott overexpressziós stratégia (Cabral és mtsai. 2012). 


\section{CÉLKITÜZÉSEK}

A C. parapsilosis-nak napjainkban egyre nagyobb egészségügyi jelentőséget tulajdonítanak. Munkánk elsődleges célja ezért az volt, hogy megvizsgáljuk ezen opportunista humán patogén élesztő, szekretált aszpartil proteinázainak a virulenciában betöltött szerepét. Elsősorban arra a kérdésre kerestük a választ, hogy vajon a szekretált aszpartil proteináz deficiens törzsek fenotípusa és virulenciája eltér-e a vad típustól? Tekintettel arra, hogy $C$. parapsilosis esetében a genetikai módosítások eszköztára korlátozott, céljaink között szerepelt, egy erre a fajra optimalizált kísérleti rendszer alapjainak kidolgozása is, amely lehetővé teszi a vizsgálni kívánt gének túlműködtetését.

Hogy a felmerült kérdésekre választ kapjunk, az alábbi célokat tűztük ki:

(1.) a C. parapsilosis SAPP1 génjére deléciós mutáns törzs létrehozása, majd a létrehozott mutáns törzs gazda-patogén interakciók során történő vizsgálata, illetve virulenciájának jellemzése;

(2.) a fent említett $C$. parapsilosis $S A P P 1$ génjére deléciós mutáns törzs alkalmazásával a SAPP2 gén deléciójának kivitelezése, majd az így létrehozott, halmozott deléciót hordozó úgynevezett „sapp negatív” mutáns törzs fenotipikus és virulenciában bekövetkezett változásának jellemzése;

(3.) egy C. albicans-ban jól müködö overexpressziós rendszer alapjainak C. parapsilosis-ra való adaptálása és annak optimalizálása. 


\section{ANYAGOK ÉS MÓDSZEREK}

5.1. A munkánk során felhasznált mikrobák, előállított deléciós mutáns törzsek és felhasznált primerek

Felhasznált mikroorganizmusok (1. táblázat):

A táblázat a munkánk során felhasznált mikroorganizmusokat tartalmazza

\begin{tabular}{|c|c|c|c|}
\hline Fajnév & Azonosító kód & Eredet & Genotípus \\
\hline $\begin{array}{l}\text { Candida } \\
\text { parapsilosis }\end{array}$ & GA1 & $\begin{array}{c}\text { Hamburg } \\
\text { (Németország), } \\
\text { humán vér }\end{array}$ & Vad típus \\
\hline $\begin{array}{l}\text { Candida } \\
\text { parapsilosis }\end{array}$ & CLIB 214 leu $^{-}$ & $\begin{array}{c}\text { Dublin } \\
\text { (Írország) } \\
\text { (CLIB 214 vad } \\
\text { típus: Puerto Rico, } \\
\text { Humán széklet) }\end{array}$ & leu $2 \Delta:: F R T / l e u 2 \Delta:: F R T$ \\
\hline Candida albicans & SC 5314 & $\begin{array}{c}\text { Princeton } \\
\text { (USA), } \\
\text { humán vér }\end{array}$ & Vad típus \\
\hline Escherichia coli & XL1-Blue & Sigma & $\begin{array}{c}\text { endA1 gyrA96(nalR) } \\
\text { thi-1 recA1 relA1 lac } \\
\text { glnV44 F' }:: \text { Tn10 } \\
\text { proAB+ lacIq } \\
\Delta(\text { lacZ)M15] } \\
\text { hsdR17(rK- } \mathrm{mK}+)\end{array}$ \\
\hline Escherichia coli & DH5 $\alpha$ & Sigma & $\begin{array}{c}\text { F- endA1 glnV44 thi-1 } \\
\text { recA1 relA1 gyrA96 } \\
\text { deoR nupG } \\
\text { Ф80dlacZ } \Delta \mathrm{M} 15 \\
\Delta(\text { lacZYA-argF)U169, } \\
\text { hsdR17(rK- mK }+), \lambda-\end{array}$ \\
\hline Escherichia coli & DB3.1 & Invitrogen & 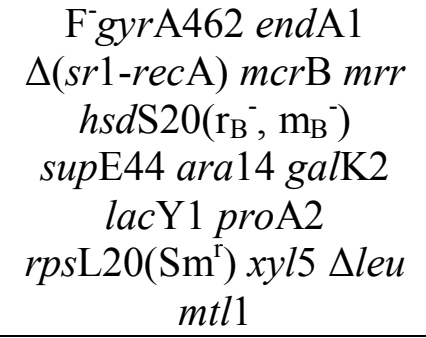 \\
\hline
\end{tabular}


Előállított mutáns törzsek (2. táblázat):

A táblázat a munkánk során elöállított $C$. parapsilosis törzseket tartalmazza

\begin{tabular}{|c|c|}
\hline $\begin{array}{l}\text { Törzs neve } \\
\text { (Rövidítve) }\end{array}$ & Genotípus \\
\hline$\Delta$ sappla NAT $^{\mathrm{R}}$ & sapplaA $: \because F R T-S A T 1-F R T / S A P P 1 a / S A P P 1 b / S A P P 1 b$ \\
\hline$\Delta$ sappla NAT $^{\mathrm{S}}$ & sapplaA: $: F R T / S A P P 1 a / S A P P 1 b / S A P P 1 b$ \\
\hline 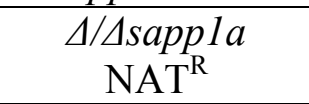 & sapp1aA::FRT/sapp1aA::FRT-SAT1-FRT/SAPP1b/SAPP1b \\
\hline$\Delta / \Delta$ sappla $\mathrm{NAT}^{\mathrm{S}}$ & sapplaA::FRT/sappla::FRT/SAPP1b/SAPP1b \\
\hline$\Delta \operatorname{sapplb} \mathrm{NAT}^{\mathrm{R}}$ & sapp1bA :FRT-SAT1-FRT/SAPPIb/SAPPIa/SAPPIa \\
\hline$\triangle$ sapplb $\mathrm{NAT}^{\mathrm{S}}$ & sapp1b4::FRT/SAPP1b/SAPP1a/SAPPla \\
\hline 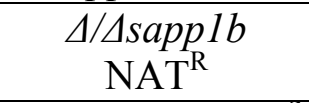 & 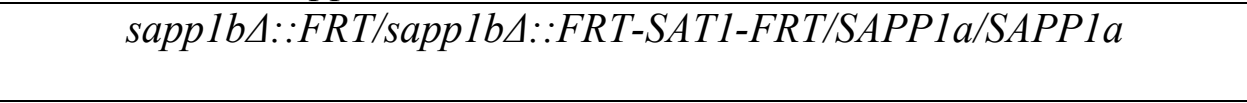 \\
\hline$\Delta / \Delta$ sapp $1 b \mathrm{NAT}^{\mathrm{S}}$ & sapplbA::FRT/sapplb::FRT/SAPP1a/SAPPla \\
\hline 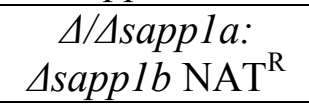 & sapplaA::FRT/sapplaA:FRT/sapp1bA::FRT-SAT1-FRT/SAPP1b \\
\hline 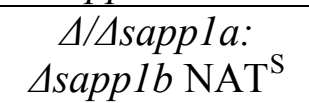 & 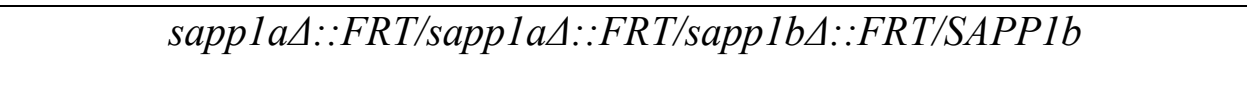 \\
\hline 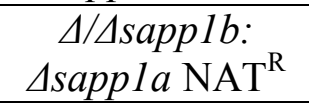 & 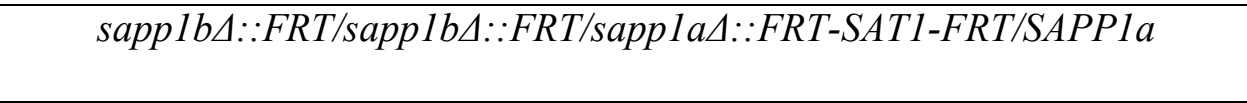 \\
\hline 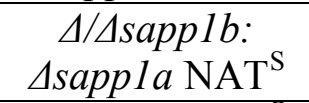 & 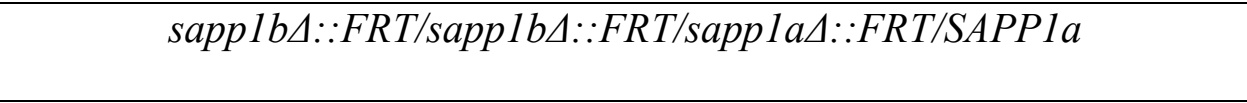 \\
\hline sappl -/- $\mathrm{NAT}^{\mathrm{R}}$ & 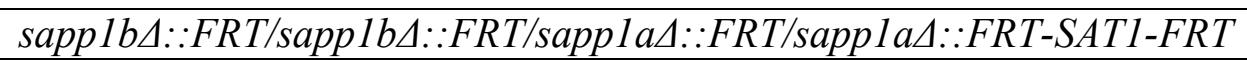 \\
\hline sappl -/- NAT ${ }^{\mathrm{S}}$ & sapp $1 b \Delta:: F R T /$ sapp $1 b \Delta:: F R T /$ sappla $1:: F R T /$ sappla $1:: F R T$ \\
\hline $\begin{array}{l}\text { sapp1 -/-:sapp2 - } \\
\text { /- NAT R }\end{array}$ & 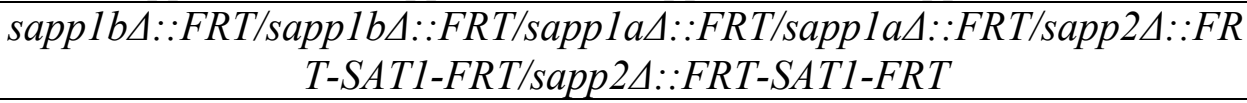 \\
\hline $\begin{array}{l}\text { sapp1 -/-:sapp2 - } \\
\text { /- NAT }\end{array}$ & 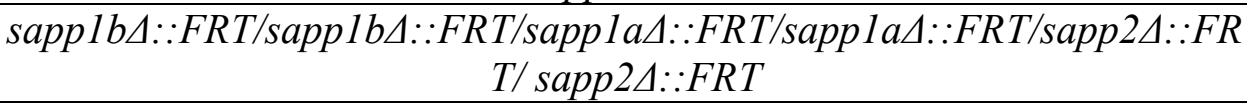 \\
\hline $\begin{array}{l}\text { CLIB } 214 \text { leu- - } \\
\text { Fogadó törzs } \\
\text { NAT }^{\mathrm{R}} *\end{array}$ & leu2A::FRT/leu2A::FRT::cprp10A::FRT-SAT1-FRT-caRP10/cpRP10 \\
\hline $\begin{array}{l}\text { CLIB } 214 \text { leu- - } \\
\text { Fogadó törzs } \\
\text { NAT }^{S} *\end{array}$ & leu2A::FRT/leu2A::FRT::cprp10A::FRT-caRP10/cpRP10 \\
\hline $\begin{array}{c}\text { CLIB } 214-\text { GFP } \\
*\end{array}$ & $\begin{array}{c}\text { leu2A::FRT/leu2A::FRT::cprp10A::FRT-caRP10::TDH3p- } \\
\text { caGFP/cpRP10 }\end{array}$ \\
\hline
\end{tabular}

*:A létrehozott törzsek a C. parapsilosis CLIB 214 leu- auxotróf törzséből készültek el. 
Munkánk során felhasznált primerek (3. táblázat):

A táblázat a munkánk során felhasznált primereket tartalmazza.

\begin{tabular}{|c|c|}
\hline Primer neve: & Szekvencia (5'->3'): \\
\hline $\begin{array}{l}\text { SAPPla KpnI } \\
\text { Upstream Forward }\end{array}$ & TTTTTTGGTACCGTCTTCACCCTACCACAAGTGCTATGAG \\
\hline $\begin{array}{l}\text { SAPPla XhoI } \\
\text { Upstream Reverse }\end{array}$ & TTTTTTCTCGAGGAATTTGTAATTGGTGTTTGTCAGCTTTG \\
\hline $\begin{array}{l}\text { SAPPla NotI } \\
\text { Downstream } \\
\text { Forward }\end{array}$ & TTTTTTGCGGCCGCGCTCGTTGGATTATAAACAGTTCAGTTC \\
\hline $\begin{array}{l}\text { SAPPla SacI } \\
\text { Downstream } \\
\text { Reverse }\end{array}$ & TTTTTTGAGCTCGCTTATGTTGTTTATGACTTGGAAGAC \\
\hline $\begin{array}{l}\text { SAPPIb KpnI } \\
\text { Upstream Forward }\end{array}$ & TTTTTTTTGGTACCGTGACAATGTGTTGAGAAATGCTTATG \\
\hline $\begin{array}{l}\text { SAPPIb XhoI } \\
\text { Upstream Reverse }\end{array}$ & TTTTTTTTCTCGAGATTCGGAACATTGCCTCACTCAC \\
\hline $\begin{array}{l}\text { SAPPIb NotI } \\
\text { Downstream } \\
\text { Forward }\end{array}$ & TTTTTTTTGCGGCCGCCGAAGGACCTGAAATTTTAAATGACG \\
\hline $\begin{array}{l}\text { SAPPIb SacI } \\
\text { Downstream } \\
\text { Reverse }\end{array}$ & TTTTTTTTGAGCTCGAACGGAAGTTTCGATTTAGGCAATAG \\
\hline $\begin{array}{l}\text { SAPP2 KpnI } \\
\text { Upstream Forward }\end{array}$ & TTTTTTGGTACCCCATTCTCATAACCACTTCTTTGGCTG \\
\hline $\begin{array}{l}\text { SAPP2 XhoI } \\
\text { Upstream Reverse }\end{array}$ & $\begin{array}{l}\text { TTTTTTCTCGAGAATTGATAGTTGGTGACTTGACATTTAACT } \\
\text { C }\end{array}$ \\
\hline $\begin{array}{l}\text { SAPP2 NotI } \\
\text { Downstream } \\
\text { Forward }\end{array}$ & $\begin{array}{l}\text { TTTTTTGCGGCCGCGTGTTGTTATGAGACAAATCTGTAGTGT } \\
\text { AATTTG }\end{array}$ \\
\hline $\begin{array}{l}\text { SAPP2 SacI } \\
\text { Downstream } \\
\text { Reverse }\end{array}$ & TTTTTTGAGCTCGCAAACCCGATTCTTCTTAGTGCTG \\
\hline qTub4 Forward & GAACACTTATGCCGAGGACAAC \\
\hline qTub4 Reverse & ACTCTCACCACTGACTCCTTGC \\
\hline qSAPPl Forward & ACTGGACAACAAATTGCAGATG \\
\hline qSAPP1 Reverse & TAAACTGCTTCATTGCTGGTGT \\
\hline $\mathrm{q} S A P P 2$ Forward & GTCATATGGGGGATTTGCAC \\
\hline qSAPP2 Reverse & CGCTTTGCTGATGTTACCAG \\
\hline $\mathrm{q} S A P P 3$ Forward & CTGGGTCATTGATGCAAATTC \\
\hline $\mathrm{q} S A P P 3$ Reverse & AGGTTGAGGTGTCTGGATCG \\
\hline $\begin{array}{l}\text { Cp RP10 KpnI } \\
\text { Upstream Forward }\end{array}$ & $\begin{array}{l}\text { TTTTTTTTGGTACCAGAGACTTTCTAAAGGAAAGAAAGGAT } \\
\text { TG }\end{array}$ \\
\hline
\end{tabular}




\begin{tabular}{|c|c|}
\hline $\begin{array}{l}\text { Cp RP10 XhoI } \\
\text { Upstream Reverse }\end{array}$ & TTTTTTTTCTCGAGAATGATCTTATTTTGTCTGAGGTGAAAT \\
\hline $\begin{array}{l}\text { Cp RP10 SacI } \\
\text { Downstream } \\
\text { Forward }\end{array}$ & TTTTTTTTGAGCTCAAATCAAAAAGACCACTTATGCTCAATC \\
\hline $\begin{array}{l}\text { Cp RP10 SacI } \\
\text { Downstream } \\
\text { Reverse }\end{array}$ & TTTTTTTTGAGCTCTTAAACTGATTCCAAAACAACATCCTTG \\
\hline $\begin{array}{l}\text { Ca RP10 NotI } \\
\text { Forward }\end{array}$ & $\begin{array}{l}\text { TTTTTTTTGCGGCCGCATATAATCACCAACTCAAGTACAACA } \\
\text { TG }\end{array}$ \\
\hline $\begin{array}{l}\text { Ca RP10 NotI } \\
\text { Reverse }\end{array}$ & $\begin{array}{l}\text { TTTTTTTTGCGGCCGCTTCAGTTATCATTATCCTTAAACAGA } \\
\text { TTC }\end{array}$ \\
\hline $\begin{array}{l}C p W O R 1 \text { attB1 } \\
\text { Forward }\end{array}$ & $\begin{array}{l}\text { GGGGACAAGTTTGTACAAAAAAGCAGGCTTGATGTCAGCCA } \\
\text { CTAACСTAGCTCCTACTTTAC }\end{array}$ \\
\hline $\begin{array}{l}C p W O R 1 \text { attB2 } \\
\text { Reverse }\end{array}$ & $\begin{array}{l}\text { GGGGACCACTTTGTACAAGAAAGCTGGGTCTAGAATCGTTG } \\
\text { ACCATGTAAGGATGTAGG }\end{array}$ \\
\hline $\begin{array}{l}\text { Cd LEU2 NotI } \\
\text { Forward }\end{array}$ & TTTTTTTTGCGGCCGCAGCTCGGATCCACTAGTAACG \\
\hline $\begin{array}{l}\text { Cd LEU2 SpeI } \\
\text { Reverse }\end{array}$ & TTTTTTTTACTAGTACCAGTGTGATGGATATCTGC \\
\hline $\begin{array}{l}\text { Cd LEU2 SacI GTW } \\
\text { Forward }\end{array}$ & TTTTTTTTGAGCTCGCCGCCAGTGTGCTGGAATTC \\
\hline $\begin{array}{l}\text { Cd LEU2 SpeI GTW } \\
\text { Reverse }\end{array}$ & TTTTTTTTACTAGTCCTTACCTACCCATGTCTAGA \\
\hline qWOR1 Forward & CTGCCACACCAACAACAGCT \\
\hline qWOR1 Reverse & TGCCATTACCGCTTTGCTGC \\
\hline
\end{tabular}

\subsection{Candida transzformációhoz és Southern hibridizációhoz használt reagensek}

Transzformációhoz használt oldatok

TB puffer: $10 \mathrm{mM}$ PIPES, $15 \mathrm{mM} \mathrm{CaCl}_{2} * \mathrm{H}_{2} \mathrm{O}, 250 \mathrm{mM} \mathrm{KCl}, 55 \mathrm{mM} \mathrm{MnCl}_{2} * 7 \mathrm{H}_{2} \mathrm{O}, \mathrm{pH}=$ 6,7

10x TE (Tris-EDTA) puffer: $100 \mathrm{mM}$ Tris, $10 \mathrm{mM}$ EDTA, pH 7,5

1x TE (Tris-EDTA) puffer: 10x-es törzsoldatból hígítva

1x TE + 0,1M lítium-acetát puffer (TELIOAC): 1x TE puffer, 0,1 M koncentrációjú lítiumacetáttal kiegészítve $\mathrm{pH} 7,5$

1 M DTT (ㅁitiotreitol) oldat: 1 M-os oldat, sterilre szürve 
YPD-1M Szorbitol oldat: YPD tápoldat ( $0,5 \%$ élesztő kivonat, $1 \%$ pepton, $1 \%$ D-glükóz), 1 M szorbit

PLATE oldat: 0,1 M lítium-acetát, 1x TE puffer és $80 \%$, 50 \% PEG 3350 tartalmú oldat

\section{Southern hibridizációhoz használt oldatok:}

20x SSC oldat: $0,3 \mathrm{M}$ nátrium-citrát és $3 \mathrm{M} \mathrm{NaCl}$ tartalmú oldat

Denaturáló oldat: $2 \% \mathrm{NaOH}$ és $8,76 \% \mathrm{NaCl}$ tartalmú oldat

Neutralizáló oldat: $0,5 \mathrm{M}$ TRIS ( $\mathrm{pH} 7,5), 8,76 \% \mathrm{NaCl}$ és $10^{-3} \mathrm{M}$ EDTA

Hibridizációs puffer: 5x SSC oldat, 0,1\% N-lauril-szarkozin (Sigma), 0,02\% SDS, $1 \%$

Blocking reagens (Roche)

Mosó oldat (I.): 2x SSC oldat, 0,1 \% SDS

20x tömény Mosó oldat (II.): 2x SSC és $2 \%$ SDS

10x tömény 1. Puffer: $1 \mathrm{M}$ maleinsav, 1,5 M NaCl, pH 7,5

2. Puffer: $1 \%$ Blocking reagens $1 x$ tömény 1 . Pufferben oldva

2. Puffer antitest konjugátummal: $5 \mathrm{ml}$ 2. Puffer $1 \mu$ l antitest konjugátummal (Roche) kiegészítve

3. Puffer: $0,1 \mathrm{M}$ TRIS, $0,1 \mathrm{M} \mathrm{NaCl}, 50 \mathrm{mM} \mathrm{MgCl} 2$

NBT/BCIP színreagens (Roche)

\subsection{Gateway reakcióhoz használt reagensek}

1x TE puffer $(\mathrm{pH} \mathrm{8,0)}$

BP clonase II (Invitrogen)

LR clonase II (Invitrogen)

5.4. Bakteriális plazmid tisztításhoz és gomba genomi DNS tisztításhoz használt reagensek

Lízis puffer: $50 \mathrm{mM}$ glükóz, $10 \mathrm{mM}$ EDTA, $25 \mathrm{mM}$ TRIS pH =7,5

Alkalikus SDS: 4,4 ml steril desztillált víz, $100 \mu 110$ M NaOH, 0,5 ml 20\% SDS

High salt: $29,4 \mathrm{~g}$ kálium-acetát, 11,5 $\mathrm{ml}$ ecetsav, 28,5 $\mathrm{ml}$ steril desztillált víz

Lízis puffer élesztő genomi DNS tisztításhoz: $1 \%$ SDS, 50 mM EDTA, 100 mM TRIS

$\mathrm{pH}=8$ 
7 M-os ammónium - acetát

\subsection{Fagocitózis vizsgálathoz alkalmazott reagensek}

FITC-puffer: $100 \mathrm{mM} \mathrm{NaCl}, 50 \mathrm{mM} \mathrm{NaHCO}$

FACS puffer: $0,5 \%$ FBS 1 x-es PBS-ben

\subsection{Scanning elektronmikroszkópiához használt reagens}

Sorenson-puffer: $0,133 \mathrm{M} \mathrm{Na}_{2} \mathrm{HPO}_{4}, 0,133 \mathrm{M} \mathrm{KH}_{2} \mathrm{PO}_{4} \mathrm{pH}=7,5$

\subsection{Tenyésztéshez használt táptalajok, tápoldatok}

YPD táptalaj, tápoldat: $0,5 \%$ élesztő kivonatot, $1 \%$ peptont és $1 \%$ D-glükóz. Táptalaj készítéséhez a táplevest 2,5\% agarral egészítettük ki. A bakteriális kontamináció elkerülése érdekében a tápoldathoz és a táptalajhoz, azok megfelelő hőmérsékletüre hülését követően, $1 \%$ penicillin-sztreptomicin (Sigma) oldatot adtunk (YPD-PS).

YPD-NAT táptalaj, tápoldat: A deléciós transzformánsok elóállítása során az YPD-PS tápoldat/táptalaj $100 \mathrm{ml}$-ét $100 \mu \mathrm{l}$ mennyiségü, $100 \mathrm{mg} / \mathrm{ml}$ koncentrációjú nourzeotricin (clonNAT, Werner Bioagents) oldattal egészítettük ki a transzformáns telepek szelekciójának érdekében. A domináns szelekciós marker kivágódása után az újonnan NAT szenzitívvé váló telepeket szubletális mennyiséget tartalmazó (0,5 $\mu \mathrm{l}$ NAT/ 100 ml YPD) csészén szelektáltuk.

Minimál táptalaj: 0,95 \% élesztő nitrogén bázis, $2 \%$ glükóz, 2,5 \% agar, $10 \%$ 10x drop-out médium.

Drop-out médium (10x tözsoldat): 0,02\% arginin, 0,03\% izoleucin, 0,03\% lizin, 0,02\% metionin, $0,05 \%$ fenilalanin, $0,2 \%$ treonin, $0,03 \%$ tirozin, $0,02 \%$ uracil, $0,15 \%$ valin, $0,2 \%$ adenin, $0,2 \%$ triptofán.

LB táptalaj, tápoldat: $0,5 \%$ élesztő kivonat, $1 \%$ tripton és $1 \%$ nátrium-klorid. Táptalaj készítéséhez a táplevest 2,5\% agarral egészítettük ki. E. coli XL1-Blue és DH5a törzsek transzformációja során az LB táptalaj/tápoldat 100 ml-ét $200 \mu 1$ mennyiségü, $50 \mathrm{mg} / \mathrm{ml}$ koncentrációjú ampicillin (Sigma), illetve $200 \mu 150$ mg/ml koncentrációjú kanamicin (Sigma) 
antibiotikummal egészítettük ki ( $\left.\mathrm{LB}^{\mathrm{AMP}} / \mathrm{LB}^{\mathrm{CHL}}\right)$. E. coli $\mathrm{DB} 3.1$ törzs transzformációja során az LB táptalaj/tápoldat 100 ml-ét $200 \mu 150 \mathrm{mg} / \mathrm{ml}$ koncentrációjú kanamicin (Sigma), illetve $200 \mu \mathrm{l}$ mennyiségü, $50 \mathrm{mg} / \mathrm{ml}$ koncentrációjú ampicillin (Sigma), valamint $34 \mu 134 \mathrm{mg} / \mathrm{ml}$ koncentrációjú kloramfenikol (Sigma) oldattal egészítettük ki ( $\left.\mathrm{LB}^{\mathrm{KAN}+\mathrm{CHL}} / \mathrm{LB}^{\mathrm{AMP}+\mathrm{CHL}}\right)$.

SOB tápoldat: $2 \%$ tripton, $0,5 \%$ élesztő kivonat, $10 \mathrm{mM} \mathrm{NaCl}, 2,5 \mathrm{mM} \mathrm{KCl}, 10 \mathrm{mM} \mathrm{MgCl}$, $10 \mathrm{mM} \mathrm{Mg}_{2} \mathrm{SO}_{4} * 7 \mathrm{H}_{2} \mathrm{O}$, melynek pH-ját 6,7 értékre állítottuk be $5 \mathrm{M} \mathrm{KOH}$ oldattal.

PBMC tápoldat: A humán mononukleáris sejteket $1 \%$ penicillin-szterptomicin oldatot (Sigma), és 10 \% hőinaktivált humán szérumot (Lonza) tartalmazó vagy szérummentes RPMI 1640 tápoldatban (Lonza) tenyésztettük.

PBMC-DM tápoldat: Primer makrofágok differenciáltatáshoz a mononukleáris sejteket $1 \%$ penicillin-szterptomicin oldatot és $10 \mathrm{ng} / \mathrm{ml}$ koncentrációjú granulocita-monocita kolónia stimuláló faktort (GM-CSF, Sigma) tartalmazó X-VIVO (Lonza) tápoldatban tenyésztettük.

YNB-Maltóz tápoldat: A deléciós transzformánsok létrehozása során a domináns szelekciós nourzeotricin marker kirekombinálódására szolgáló tápoldat $1 \mathrm{x}$-es töménységü élesztő nitrogén bázist (yeast nitrogen base, YNB (Sigma)), valamint $2 \%$ maltózt tartalmazott. A tápoldatot $1 \%$ penicillin-sztreptomicin oldattal (Sigma) egészítettük ki.

YCB-BSA tápoldat: A szekretált aszpartil proteinázok termelődését elősegítő indukciós tápoldat 1x-es töménységű élesztő-szénbázis (yeast carbon base, YCB (Sigma)), valamint $2 \%$ borjú szérum albumint (bovine serum albumine, BSA (Sigma) tartalmazott, melyet $1 \%$ penicillin-sztreptomicin oldattal (Sigma) egészítettünk ki.

Proteináz aktivitás kimutatására szolgáló táptalaj: A szekretált savas proteinázok szemikvantitatív kimutatására szolgáló táptalaj $1 \mathrm{x}$-es töménységü YCB-t, valamint $0,2 \%$ BSA-t tartalmazott, melyet 2,5\% agarral és a megfelelö hömérsékletüre hülést követően $1 \%$ penicillin-sztreptomicin oldattal (Sigma) egészítettünk ki. 


\subsection{Tenyésztési körülmények}

Candida törzsek fenntartása: Az élesztő törzseket YPD-PS, valamint YPD-NAT táptalajon tartottuk fenn, kéthavonta frissítettük, 2 napig $30{ }^{\circ} \mathrm{C}$-on inkubáltuk, ezt követöen $4{ }^{\circ} \mathrm{C}$-os hűtőben tároltuk. A létrehozott törzsek hosszú távú tárolását 20\% glicerinnel kiegészített YPD-PS illetve YPD-NAT tápoldatban végezzük $-80{ }^{\circ} \mathrm{C}$ hőmérsékleten.

Candida törzsek tenyésztése: Az élesztőket transzformációs kísérletekhez 100 ml YPD-PS tápoldatban szaporítottuk fel. A leoltott mikrobákat $30{ }^{\circ} \mathrm{C}$-on, $200 \mathrm{rpm}$ fordulatszámmal egy éjszakán át rázattuk. Egyéb vizsgálatokhoz a törzseket $2 \mathrm{ml}$ YPD-PS tápoldatban szaporítottuk fel, szintén $30^{\circ} \mathrm{C}$-on, 200 -as fordulatszám mellet egy éjszakán keresztül rázatva.

\subsection{Primer sejtek izolálása}

PBMC-k izolálása és differenciáltatása: A perifériás vérből származó mononukleáris sejteket (Peripherial $\underline{B}$ lood Mononuclear Cells, PBMC) egészséges felnőtt donorok véréből előállított vérkészítményből („,buffy coat”) izoláltuk Ficoll Paque Plus (GE Healthcare) sűrűség grádiens centrifugálással $\left(175 \mathrm{~g}, 30\right.$ perc, $\left.4{ }^{\circ} \mathrm{C}\right)$. A PBMC frakciót összegyüjtöttük, kétszer PBS-sel mostuk, majd a vörösvértestek eltávolítása érdekében ACK lízis pufferrel (150 mM NH $4 \mathrm{Cl}, 10 \mathrm{mM} \mathrm{KHCO}_{3}, 0,1 \mathrm{mM} \mathrm{Na}_{2}$ EDTA) kezeltük és ismételten centrifugáltuk (220 g, 10 perc). A sejteket szérummentes PBMC tápoldatban vettük fel, majd a felhasználás módjától függően 12, 24 vagy 96 mintahelyes tenyésztőedénybe pipettáztuk őket, és két órán keresztül inkubáltuk $\left(37{ }^{\circ} \mathrm{C}, 100 \%\right.$ relatív páratartalom, $5 \% \mathrm{CO}_{2}$ tenzió). Ezután az úszó sejteket eltávolítottuk, a tenyésztőedény aljához letapadt monocitákat előmelegített 1x-es PBS-sel mostuk, és a mintahelyekbe megfelelő mennyiségü PBMC-DM tápoldatot adtunk. A sejteket 7 napon keresztül inkubáltuk $\left(37^{\circ} \mathrm{C}, 100 \%\right.$ relatív páratartalom, $5 \% \mathrm{CO}_{2}$ tenzió) a tápoldat 2 naponkénti cseréjével.

\subsection{Kompetens sejtek készítése}

Kompetens $\boldsymbol{E}$. coli sejtek készítése: Kompetens E. coli sejt készítéséhez egy telepnyi XL1Blue/DH5 /DB 3.1 E.coli inokulumot $25 \mathrm{ml}, 10 \mu \mathrm{g} / \mathrm{ml}$ tetraciklin tartalmú LB tápoldatba oltottunk, majd hozzávetőlegesen 8 órán keresztül $37^{\circ} \mathrm{C}$-on 250 rpm rázatással növesztettünk. Az így felnövesztett starter tenyészetből $15 \mathrm{ml}-\mathrm{t} 250 \mathrm{ml}$ SOB tápoldatba átoltottunk, majd 16 
${ }^{\circ} \mathrm{C}$-on $175 \mathrm{rpm}$ rázatás mellett egy éjszakán keresztül növesztettük. Másnap, amennyiben a kultúra az $\mathrm{OD}=0,4$ értéket elérte, a kultúrát $4{ }^{\circ} \mathrm{C}$-on 5000 rpm-en 10 percig centrifugáltuk. A sejteket $80 \mathrm{ml}$ TB pufferben felszuszpendáltuk, majd $8 \%$ Dimetil-szulfoxidot (DMSO) (Sigma) adtunk hozzá. Az így elkészített szuszpenziót $100 \mu$ l-es adagokban folyékony nitrogénben fagyasztottuk, majd felhasználásig $-80{ }^{\circ} \mathrm{C}$-on tároltuk.

Kompetens $C$. parapsilosis sejtek készítése elektroporációhoz: Kompetens $C$. parapsilosis sejt készítéséhez egy kacsnyi inokulumot $100 \mathrm{ml}$ YPD-PS tápoldatba oltottunk, majd $30{ }^{\circ} \mathrm{C}$ on 200 rpm rázatás mellett egy éjszakán keresztül növesztettük. Másnap az ily módon felnövesztett kultúrát 2 darab 50 ml-es Falcon-csőbe szétöntve $4{ }^{\circ} \mathrm{C}$-on, 3000 rpm-en 5 percig centrifugáltuk. A leülepített sejteket $50 \mathrm{ml}$ TE pufferben felszuszpendáltuk, újra centrifugáltuk, majd következő lépésben $30 \mathrm{ml} 1 \mathrm{x} \mathrm{TE}+0,1 \mathrm{M}$ lítium-acetát (Sigma) pufferben felszuszpendáltuk, majd 45 percig $30{ }^{\circ} \mathrm{C}$-on $200 \mathrm{rpm}$ mellett rázattuk. Az inkubációs idő letelte után $750 \mu 11 \mathrm{M}$ koncentrációjú ditiotreitol (DTT) oldatot adtunk a szuszpenzióhoz, majd további 15 percig az elöbb említett körülmények közt rázattuk a szuszpenziót. Az inkubációs idő letelte után a szuszpenziót hideg steril desztillált vízzel 50 ml-re egészítettük ki és $4{ }^{\circ} \mathrm{C}$-on, 3000 rpm-en 5 percig centrifugáltuk. A sejteket ezután kétszer jéghideg steril desztillált vízzel, majd utolsó lépésként szintén jéghideg $1 \mathrm{M}$ koncentrációjú szorbitol oldattal mostuk. Az így elkészített kompetens sejteket felhasználásig jégen tároltuk.

\subsection{Kompetens sejtek transzformálása}

Kompetens $\boldsymbol{E}$. coli sejtek transzformálása: A - $80{ }^{\circ} \mathrm{C}$-on tárolt kompetens sejtekből $100 \mu \mathrm{l}$ szuszpenziót 10 percig jégen inkubáltunk. 10 perc után a sejtekhez pipettáztuk a transzformálni kívánt DNS-t, majd további 25 percig az elegyet jégen tároltuk. Az inkubációs idő után a sejteket $42{ }^{\circ} \mathrm{C}$-os hősokknak vetettük alá 2 percig, majd $800 \mu 1$ LB tápoldatot pipettáztunk rájuk. A sejteket ezután $37^{\circ} \mathrm{C}$-on 40 percig inkubáltuk, majd szelektív LB táptalajra szélesztettük, a megfelelő antibiotikumokkal kiegészítve.. A csészéket egy éjszakán keresztül $37{ }^{\circ} \mathrm{C}$-on inkubáltuk.

C. parapsilosis sejtek transzformálása - elektroporáció: A „Kompetens C. parapsilosis sejtek készítése" alfejezetben leírt módon előállított sejtek $40 \mu$ l-éhez $5 \mu$ g mennyiségü transzformáló DNS-t adtunk, majd 0,2 cm átmérőjü, hütött elektroporáló küvettába (Bio Rad) 
tettük, transzformálásig jégen tároltuk. Az elektroporáció paraméterei: 1,5 kV, $25 \mu \mathrm{F}, 200 \Omega$ voltak. Az elektroporáció után a sejtekhez $800 \mu 11 \mathrm{M}$ szorbitollal kiegészített YPD-PS tápoldatot adtunk, majd az elegyet $2 \mathrm{ml}, 1 \mathrm{M}$ szorbitollal kiegészített YPD-PS tápoldatba pipettáztuk, majd 3 órán keresztül $30{ }^{\circ} \mathrm{C}$-on inkubáltuk. Az inkubációs idő letelte után a sejteket centrifugáltuk ( $4{ }^{\circ} \mathrm{C}, 3000 \mathrm{rpm}, 5$ perc), $200 \mu 11 \mathrm{M}$ szorbitollal kiegészített YPD-PS tápoldatban felszuszpendáltuk, majd YPD-NAT csészére szélesztettük. A transzformáns telepeket hordozó csészéket 2 napig $30{ }^{\circ} \mathrm{C}$-on inkubáltuk. A transzformálandó deléciós konstrukciók $5 \mu \mathrm{g}$ mennyiségét $200 \mu$ l végtérfogatban KpnI- SacI egy éjszakán át tartó kettős emésztéssel kezeltük. Ellenőrzésként az emésztési elegy $3 \mu$ l-ét 0,8 \%-os TAE gélben megfuttattuk, a maradék mennyiséget izopropanol (13000 rpm, 10 perc) és etanol (13000 rpm, 5 perc) segítségével csaptuk ki, majd $5 \mu \mathrm{l}$ steril desztillált vízben szuszpendáltuk fel.

\section{C. parapsilosis sejtek transzformálása - kémiai transzformálás: A C. parapsilosis sejteket} egy éjszakán át $5 \mathrm{ml}$ mennyiségü YPD tápoldatban, $30{ }^{\circ} \mathrm{C}$-on, egy éjszakán át $200 \mathrm{rpm}$ rázatás mellett növesztettük. Másnap ezen starter kultúra $500 \mu$ l-ét $30 \mathrm{ml}$ YPD tápoldatba oltottuk át, majd OD = 1,0 értékig növesztettük ( 4 óra). A tenyészetet ezután centrifugáltuk (3000 rpm, $4{ }^{\circ} \mathrm{C}$, 5 perc), majd $3 \mathrm{ml}$ jéghideg desztillált vízzel mostuk. A szuszpenziót ezután $1 \mathrm{ml}$ jéghideg TELOAC pufferben mostuk, majd $200 \mu$ TELIOAC pufferben szuszpendáltuk fel. A szuszpenzió $100 \mu$ l-éhez $10 \mu 110 \mathrm{mg} / \mathrm{ml}$ koncentrációjú hering sperma DNS-t (Sigma) adtunk (a hering sperma DNS-t 10 perces forralással denaturáltuk, majd jégen tároltuk), valamint a transzformáló DNS $20 \mu$ l-ét adtuk az elegyhez. Az elegyet 30 percen keresztül 30 ${ }^{\circ} \mathrm{C}$-on inkubáltuk. Az inkubációs idő után $700 \mu$ PLATE oldatot adtunk az elegyhez, majd 30 ${ }^{\circ} \mathrm{C}$-on egy éjszakán keresztül inkubáltuk. Másnap az elegyet $44{ }^{\circ} \mathrm{C}$-on 15 percig inkubáltuk, majd $13000 \mathrm{rpm}$ fordulattal 30 másodpercig centrifugáltuk. $1 \mathrm{ml}$ YPD oldattal mostuk a sejteket (a pellet felkeverése nélkül), majd $100 \mu$ Y YPD tápoldatban szuszpendáltuk fel azokat. 2 órán keresztül $30{ }^{\circ} \mathrm{C}$-on $200 \mathrm{rpm}$ rázatás mellett inkubáltuk, majd minimál táptalajra szélesztettük a sejteket, melyeket $30{ }^{\circ} \mathrm{C}$-on 2 napig inkubáltunk. A transzformálni kívánt konstrukciók $10 \mu \mathrm{g}$ mennyiségét $200 \mu$ végtérfogatban StuI enzimmel egy éjszakán át tartó emésztéssel kezeltük. Ellenőrzésként az emésztési elegy $3 \mu$ l-ét 0,8 \%-os TAE gélben megfuttattuk, a maradék mennyiséget izopropanol (13000 rpm, 10 perc) és etanol (13000 rpm, 5 perc) segítségével csaptuk ki, majd $20 \mu \mathrm{l}$ steril desztillált vízben szuszpendáltuk fel. 


\subsection{Vektorok létrehozása}

Deléciós konstrukciók létrehozása: A SAPPla lokusz deléciójának végrehajtásához a pSFS2Sapp1a, a SAPP1b lokusz deléciójának végrehajtásához a pSFS2Sapp1b, míg a SAPP2 lokusz deléciójának végrehajtásához a pSFS2Sapp2 vektorokat használtuk fel.

A pSFS2Sapp1a konstrukció elkészítéséhez 648 bp méretű upstream homológ szekvenciát, valamint 721 bp méretü downstream homológ szekvenciát szaporítottuk fel a $C$. parapsilosis GA1 genomi DNS-ét templátként felhasználva. Az upstream homológ régió felszaporításához a SAPPla KpnI upstream forward és a SAPPla XhoI upstream reverse, valamint a downstream homológ régió felszaporításához a SAPPla NotI downstream forward, és a SAPPla SacI downstream reverse primer párokat használtuk (3. táblázat).

A pSFS2Sapp1b konstrukció elkészítéséhez 614 bp méretű upstream és 386 bp méretü downstream homológ szekvenciát amplifikáltunk a C. parapsilosis GA1 genomi DNSét templátként felhasználva. Az upstream homológ régió felszaporításához a SAPP1b KpnI upstream forward és a $S A P P 1 b X h o$ I upstream reverse, valamint a downstream homológ régió felszaporításához a $S A P P 1 b$ NotI downstream forward, és a $S A P P 1 b$ SacI downstream reverse primer párokat használtuk (3. táblázat).

A pSFS2Sapp2 konstrukció elkészítéséhez 260 bp nagyságú upstream és 223 bp nagyságú downstream homológ szekvenciát amplifikáltunk a C. parapsilosis GA1 genomi DNS-ét templátként felhasználva. Az upstream homológ régió felszaporításához a SAPP2 $K p n I$ upstream forward és a $S A P P 2 X h o$ I upstream reverse valamint a downstream homológ régió felszaporításához a $S A P P 2$ NotI downstream forward és a $S A P P 2$ SacI downstream reverse primer párokat használtuk (3. táblázat).

Az amplifikáció után az upstream homológ régiót valamint az üres pSFS2 vektort KpnI - XhoI, a downstream homológ régiót valamint az üres pSFS2 vektort Not I - SacI 37 ${ }^{\circ} \mathrm{C}$-on egy éjszakán át tartó emésztésnek vetettük alá. Az emésztett fragmentumokat gélből való visszaizolálást követően $K p n I$ - XhoI, valamint NotI - SacI helyekre klónoztuk.

\section{C. parapsilosis fogadó törzsének létrehozásához használt konstrukció létrehozása: A $C$.} parapsilosis fogadó törzsének létrehozásához a CLIB 214 leu auxotróf törzset használtuk fel. Ezen törzs genomi DNS-éből az RP10 lokusz upstream részének 319 bp méretű szakaszát a $C p$ RP10 KpnI upstream forward és Cp RP10 XhoI upstream reverse primerek segítségével, valamint ugyanezen lokusz downstream részének 326 bp méretủ szakaszát a Cp RP10 SacI downstream forward és $C p \quad R P 10 \quad S a c$ I downstream reverse primerek segítségével 
amplifikáltuk. A C. albicans RP10 lokuszát (770 bp) a Ca RP10 NotI forward és a Ca RP10 NotI reverse primerekkel amplifikáltuk (3. táblázat).

Az amplifikáció után a fragmentumokat a megfelelő enzimek használatával $(C$. parapsilosis $R P 10$ upstream régió esetén: KpnI és XhoI, C. parapsilosis RP10 downstream régió esetén: SacI, C. albicans RP10 régió esetén: NotI) az üres pSFS2 vektorba klónoztuk.

GFP konstrukció létrehozása: A pSN40 vektort alkalmazva a vektorról a $C$. dubliniensis LEU2 markerét a $C d L E U 2$ NotI forward és Cd LEU2 SpeI reverse primerek segítségével amplifikáltuk (3. táblázat). A kapott fragmentumot NotI és SpeI enzimekkel emésztettük, valamint ugyanezen enzimekkel a Clp10-pTDH3-GFP konstrukció URA3 markerét kivágtuk. Az emésztett, URA3 markert már nem hordozó Clp10-pTDH3-GFP vektorba a megemésztett C. dubliniensis LEU2 markert NotI és SpeI helyekre klónoztuk.

Gateway destination vektor létrehozása: A pSN40 vektort alkalmazva a vektorról a $C$. dubliniensis LEU2 markerét a Cd LEU2 SacI GTW forward és a Cd LEU2 SpeI GTW reverse primerek segítségével amplifikáltuk (3. táblázat), majd a SacI és SpeI enzimekkel emésztettük. A pTDH3-GTW vektorból SacI és SpeI kettős emésztéssel az URA3 markert kivágtuk, majd az emésztett vektorba az emésztett LEU2 markert klónoztuk, a SacI és SpeI helyek felhasználásával.

\subsection{Gateway reakciók}

A gateway reakcióhoz alkalmazni kívánt WOR1 open reading frame-t a C. parapsilosis CLIB 214 leu- törzsének genomi DNS-éből, a $C p$ WOR1 attB1 forward és a $C p$ WOR1 attB2 reverse primerpárok segítségével szapotítottuk fel. A BP és LR klonáz reakciókhoz az Invitrogen BP Clonase II és LR Clonase II kiteket használtuk.

BP klonáz reakció: Az entry klón létrehozásához a felszapotított ORF és a pDONR 221 vektor segítségével BP reakciót hajtottunk végre. A BP reakció során a felszaporított ORF végein megtalálható attB1 és attB2 helyek és a vektoron megtalálható attP1 és attP2 helyek között játszódik le a rekombináció, melynek során a felszaporított ORF a vektorba beépül. A reakciót $10 \mu \mathrm{l}$ végtérfogatban mértük össze. A reakcióhoz $1 \mu 150 \mathrm{ng} / \mu \mathrm{l}$ koncentrációjú pDONR 221 vektort, $2 \mu 1100 \mathrm{ng} / \mu 1$ koncentrációjú PCR terméket, $2 \mu 1$ BP Clonase II reakció mixet és $5 \mu 11 \mathrm{x}$ TE puffert $(\mathrm{pH}=8,0)$ adtunk. A reakciót $25^{\circ} \mathrm{C}$-on egy éjszakán át végeztük. Másnap $2 \mu$ Proteináz $\mathrm{K}$ oldatot adtunk az elegyhez, melyet $37{ }^{\circ} \mathrm{C}$-on 10 percig inkubáltuk. 
Az inkubációs idő után az elegyet $E$. coli DH5a sejtekbe transzformáltuk, majd LB $^{\mathrm{CHL}}$ csészékre szélesztettük.

LR klonáz reakció: A BP clonase reakció által létrehozott entry klón segítségével LR reakciót végeztünk el. Az LR reakció során az entry klónban megtalálható attL1 és attL2 helyek és a destination vektoron megtalálható attR1 és attR2 helyek között játszódik le a rekombináció, melynek során az entry klónba épített ORF a destination vektorba épül. Az LR reakciót szintén $10 \mu \mathrm{l}$ végtérfogatban mértük össze, az alábbiak szerint: $1 \mu 1100 \mathrm{ng} / \mu 1$

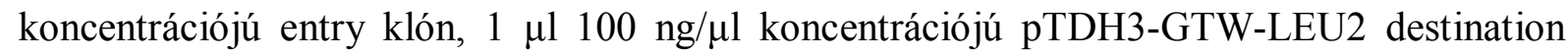
vektor, $2 \mu \mathrm{LR}$ Clonase II reakció mix és $5 \mu 11 \mathrm{x}$ TE puffer $(\mathrm{pH}=8,0)$. A reakciót $25^{\circ} \mathrm{C}$-on overnight végeztük. Másnap $2 \mu$ Proteináz K oldatot adtunk az elegyhez, melyet $37{ }^{\circ} \mathrm{C}$-on 10 percig inkubáltuk. Az inkubációs idő után az elegyet E. coli DH5 $\alpha$ sejtekbe transzformáltuk, majd $\mathrm{LB}^{\mathrm{AMP}}$ csészékre szélesztettük. Mindkét reakció esetén a jó klónokat restrikciós fragment hossz alapján azonosítottuk.

Polimeráz láncreakció: Valamennyi PCR-t a Roche Expand long template PCR System polimerase kit-tel végeztünk. Egyetlen $25 \mu$ l végtérfogatú reakció az alábbi komponenseket tartalmazta: 1x Roche Expand Long Template Buffer 1. (gyárilag $20 \mathrm{mM} \mathrm{MgCl}$-vel), 0,25$0,25 \mu \mathrm{M}$ forward és reverse primer, 0,2-0,2 mM dNTPs (Sigma), 20-50 ng genomi DNS templát és 1 unit Expand Long Template Enzyme Mix. A fenti reakcióelegyet az alábbi körülmények között inkubáltuk: 3 perc, $95{ }^{\circ} \mathrm{C}$ predenaturáció, majd 35 cikluson keresztül 1 perc, $94^{\circ} \mathrm{C}, 0: 45$ perc $60^{\circ} \mathrm{C}$ és 2 perc $68^{\circ} \mathrm{C}$ végül 7 perc, $68^{\circ} \mathrm{C}$ utópolimerizáció.

\subsection{Bakteriális plazmid, gomba genomi DNS és gomba RNS tisztítása}

Bakteriális plazmid tisztítása: A „Kompetens E. coli sejtek transzformálása” pontban leírt, $37{ }^{\circ} \mathrm{C}$-on felnövesztett transzformáns telepeket $2 \mathrm{ml}$ antibiotikummal kiegészített LB tápfolyadékba oltottunk, majd egy éjszakán át $200 \mathrm{rpm}$-en $37{ }^{\circ} \mathrm{C}$-on rázattuk. Az ily módon felnövesztett tenyészeteket másnap 1,5 ml-es Eppendorf csőbe pipettáztuk, 6000 rpm-en 5 percig ülepítettük. A kiülepített sejteket $100 \mu$ lízis pufferben felszuszpendáltuk, majd 5 percig állni hagytuk. Öt perc után $200 \mu \mathrm{l}$ alkalikus SDS-t, majd $150 \mu 1$ high salt oldatot adtunk, amely után 15 percig jégen inkubáltuk az elegyet. Ezután 0,5 ml kloroform-izoamilalkohol 24:1 arányú elegyét adtuk hozzá, 13000 rpm-en 10 percig centrifugáltuk. A felső fázisban levő DNS-t izopropanollal (13000 rpm 10 perc), majd 70 \%-os etanollal (13000 rpm 5 perc) 
csaptuk ki. A megszárított plazmid DNS-t $30 \mu$ RNáz tartalmú steril desztillált vízben szuszpendáltuk fel. A plazmidok ellenőrzése restrikciós emésztési mintázatuk alapján történt.

Nagyobb mennyiségü plazmid izolálása érdekében a transzformáns telepet $100 \mathrm{ml}$ térfogatú megfelelő antibiotikummal kiegészített LB tápfolyadékba oltottuk, egy éjszakára 200 rpm-en $37{ }^{\circ} \mathrm{C}$-on rázattuk. Másnap a bakteriális plazmid tisztítását a Geneaid Plasmid Midi Kit segítségével, a gyártó utasításai szerint végeztük.

Genomi DNS kivonás gombából: A törzseket 2 ml YPD-PS tápoldatban rázattuk (200 rpm) $30{ }^{\circ} \mathrm{C}$-on (C. albicans esetén $37{ }^{\circ} \mathrm{C}$-on) egy éjszakán át. A sejteket $3000 \mathrm{rpm}$ fordulaton 5 percig centrifugáltuk, a felülúszót eltávolítottuk, majd $500 \mu$ lízis puffert ( $1 \%$ SDS, $50 \mathrm{mM}$ EDTA, 100 mM TRIS pH = 8) és $500 \mu$ üveggyöngyöt mértünk a mintákra, amelyeket ezután 3 percen keresztül vortexeltük. A mintákhoz $275 \mu 17$ M-os ammónium-acetátot adtunk és 5 percig $65^{\circ} \mathrm{C}$-on inkubáltuk, majd 5 percre jégre helyeztük őket. A mintákat $500 \mu$ l kloroformizoamilalkohol (24:1) hozzáadását követően centrifugáltuk (10 perc $13000 \mathrm{rpm})$. A felső, vizes fázist átpipettáztuk egy másik csőbe, amelyhez $500 \mu$ lizopropanolt adtunk, és 5 percre $20{ }^{\circ} \mathrm{C}$-ra helyeztünk. Az oldatot centrifugáltuk (10 perc, $\left.13000 \mathrm{rpm}\right)$, a felülúszót eltávolítottuk, a kiülepedett csapadékra 70 \%-os etanolt mértünk, majd a mintákat a fenti paraméterekkel újból centrifugáltuk. A felülúszó eltávolítása után a mintákat beszárítottuk és $100 \mu \mathrm{l}$ RN-ázos (Sigma) bidesztillált vízben vettük fel. A kivonás sikerességének ellenőrzésére a mintákból 1-1 $\mu$ l-t futtattunk meg 0,8 \%-os agaróz gélen.

Southern hibridizáció: A genomi DNS-t a „DNS kivonás gombából” fejezetben leírtak alapján izoláltuk, és a következő restirikciós enzimekkel egy éjszakán át emésztettük (Fermentas):ClaI - BamHI (SAPPla lokusz deléciója), EcoRI (SAPPlb és SAPP2 lokusz deléciója), a gyártó utasításainak megfelelően. A DNS-t izopropanolal csaptuk ki és 70 \%-os etanollal mostuk (13000 rpm, 10 perc). A mintákat 0,8 \% agaróz gélen futtattuk DIG-labeled DNA Molecular Weight Marker VII (Roche) mellett. A fragmenteket filterre (Amersham Hybond-N (GE Healthcare)) blottoltuk és UV fénnyel kovalensen rögzítettük. A további lépéseket a Gottschling Lab (Fred Hutchinson Cancer Research Center) Southern$\begin{array}{llll}\text { hibridizációs protokollja } & \text { szerint } & \text { veztük }\end{array}$ (http://labs.fhcrc.org/gottschling/General\%20Protocols/southerns.html). A hibridizációt egy éjszakán át végeztük $65{ }^{\circ} \mathrm{C}$-on a „DIG-dUTP jelölt próbák előállítása” pontban leírt jelölt próbákkal. Hogy a fragmenteket láthatóvá tegyük a filtert Anti-digoxigenin-AP Fab fragmenttel (Roche) és NBT/BCIP színreagenssel (Roche) kezeltük. 
DIG-dUTP jelölt próbák előállítása: A DIG-jelölt próba elkészítéséhez DreamTaq DNS polimeráz kit-et (Fermentas) használtunk a gyártó által javasolt protokoll szerint. A dNTP mixet Fermentas dNTP és Digoxigenin-11-dUTP (Roche) felhasználásával állítottuk össze. A reakciótérfogat $30 \mu \mathrm{l}$ volt. A PCR program az alábbi lépéseket tartalmazta: 3 perc elődenaturáció $95^{\circ} \mathrm{C}$-on, majd 35 cikluson keresztül: 45 másodperc, $94{ }^{\circ} \mathrm{C}$-on, 15 másodperc, $60{ }^{\circ} \mathrm{C}$-on, 2 perc, $72{ }^{\circ} \mathrm{C}$-on, végül utópolimerizáció 7 percig, $72{ }^{\circ} \mathrm{C}$-on. A SAPPla lokusz detektálásához a lokusz upstream $K p n I$ forward és XhoI reverse homológ régióinak primer párját, a SAPPIb lokusz detektálásához a lokusz downstream NotI forward és SacI reverse homológ régiójának primer párját, míg a $S A P P 2$ lokusz detektálásához a lokusz downstream NotI forward és $S a c$ I reverse homológ régiójának primer párját jelöltük.

A deléciós kazetta eliminálása a genomból: A helyes integrációt hordozó transzformánsokat $1 \mathrm{x}$ YNB $+2 \%$ maltóz tartalmú tápoldatba oltottuk, egy éjszakán át $30^{\circ} \mathrm{C}$-on $200 \mathrm{rpm}$ mellett rázattuk. Másnap a sejtkoncentrációt 4000 sejt/ml számra állítottuk be, majd szubletális mennyiséget $(0,5 \mu \mathrm{g} / \mathrm{ml})$ tartalmazó YPD-NAT csészére szélesztettünk $50 \mu 1$ mennyiséget. A csészéket 2 napig $30{ }^{\circ} \mathrm{C}$-on inkubáltuk. Az inkubációs idő letelte után a kinőtt kis telepeket YPD csészékre gyüjtöttük, melyeket hasonló időtartamig hasonló hőmérsékleten inkubáltunk. A kinőtt telepeket YPD-NAT csészékre is átoltottuk, majd szintén hasonló paraméterek mellett inkubáltuk. Az YPD-NAT csészén nőni képtelen telepeket összegyüjtöttük, majd Southern hibridizáció segítségével ellenőriztük a deléciós kazetta eltűnését a genomból.

RNS kivonás gomba sejtekből: A szekretált savas proteinázok transzkripciós vizsgálatához a vad típusú és transzformáns törzseket $2 \mathrm{ml}$ YPD tápfolyadékban $30{ }^{\circ} \mathrm{C}$-on $200 \mathrm{rpm}$ rázatás mellett, egy éjszakán át tenyésztettük. Másnap a sejteket kétszer mostuk 1x PBS-ben, majd 2 $\mathrm{ml} 1 \mathrm{x}$ YCB $+2 \%$ BSA tápfolyadékban vettük fel őket. A szuszpenziót szintén $30{ }^{\circ} \mathrm{C}$-on 200 rpm rázatás mellett, egy éjszakán át tenyésztettük. Másnap a gomba RNS kivonását a Quiagen RNeasy Plant Mini Plus Kit segítségével végeztük, a gyártó utasításai szerint. A folyamat során DNáz kezelést végeztünk 30 percen keresztül, melyhez Quiagen RNase-Free DNase Set-et használtunk.

RNS minőség/mennyiség ellenőrzés: Az izolált RNS mennyiségét NanoDrop -, a minőségét Agilent 2100 Bioanalyzer készülékek segítségével határoztuk meg. 
cDNS szintézis: A reverz transzkripcióhoz Fermentas RevertAid First Strand cDNA Synthesis Kit-et használtunk a gyártó utasításainak megfelelően. Minden reakcióban 0,5-0,5 $\mu 1$ oligodT és random heaxamer primereket alkalmaztunk. A szintézis során hozzávetőlegesen $1 \mu \mathrm{g}$, vagy ha a koncentráció túl alacsony volt, akkor a maximális $12 \mu \mathrm{l}$ RSS templátot használtuk. A reakció lépései: $25^{\circ} \mathrm{C}, 5$ perc majd $42{ }^{\circ} \mathrm{C}, 60$ perc végül $70{ }^{\circ} \mathrm{C}, 5$ perc.

Valós idejű kvantitatív PCR (qRT-PCR): A reakcióhoz a reverz transzkripció termékéből 1 $\mu \mathrm{g}$ mennyiségü templát 10x-es hígításának $1 \mu$-ét használtunk. Fermentas Maxima ${ }^{\mathrm{TM}} \mathrm{SYBR}$ Green qPCR Master Mix (2x) kit-tel dolgoztunk. A reakciót $20 \mu 1$ végtérfogatban végeztük, így a gyártó által mellékelt protokollban szereplő mennyiségeket is ezzel arányosan csökkentettük. A reakciókat Bio-Rad C1000TM Thermal Cycler gépben futtattuk le a következő kondíciókkal: $95^{\circ} \mathrm{C}, 3$ perc, majd 50 cikluson keresztül $95^{\circ} \mathrm{C}, 10$ másodperc majd $60{ }^{\circ} \mathrm{C}, 30$ másodperc. A fluoreszcencia intenzitásának mérése minden ciklus végén történt. $\mathrm{Az}$ utolsó ciklust követően a termékek olvadási görbéit is megvizsgáltuk 65 - $95{ }^{\circ} \mathrm{C}$-os tartományban $0,5{ }^{\circ} \mathrm{C}$-os lépésekkel. A relatív expressziós értékek kiszámítása a $\Delta \Delta \mathrm{C}_{(\mathrm{t})}$ eljárással történt, amelyhez a berendezés saját szoftverét használtuk. Valamennyi mintát három technikai párhuzamosban mértünk le. Gomba esetén az $\alpha$-tubulin szolgált belső kontrollként.

\subsection{Proteináz aktivitás mérése}

Szekretált Proteináz aktivitás detektálása: A vad típusú és deléciós mutáns törzseket $2 \mathrm{ml}$ YPD tápoldatban egy éjszakán át $30{ }^{\circ} \mathrm{C}$-on $200 \mathrm{rpm}$ rázatás mellett tenyésztettük. Másnap a törzseket kétszer steril desztillált vízzel mostuk, majd a sejtszámot $10^{8} / \mathrm{ml}$ koncentrációjúra állítottuk be. Ebből a sejtszuszpenzióból $10 \mu$ térfogatot proteináz aktivitás kimutatására szolgáló csészére (5.6. fejezet) cseppentettünk, majd beszárítottuk. A csészéket 2 napig $30{ }^{\circ} \mathrm{C}$ on inkubáltuk, majd amidoblack festékkel festettük. A festék mosását metanol-ecetsav-víz 3:1:6 arányú elegyével végeztük. A feltisztulási zóna nagyságát ImageJ programmal analizáltuk.

\section{Sapp1 és Sapp2 fehérjék aktivitásának kvantitatív mérése fluoreszcens szubsztrát} felhasználásával: A Sapp1 és Sapp2 fehérjék aktivitásának méréséhez a vad típusú és deléciós törzseket egy éjszakán át $30{ }^{\circ} \mathrm{C}$-on $200 \mathrm{rpm}$ rázatás mellett $50 \mathrm{ml} 1 \mathrm{x} \mathrm{YCB}+2 \% \mathrm{BSA}$ tápoldatban tenyésztettük. A tenyészeteket másnap centrifugáltuk (3000 rpm, 5 perc), majd a 
felülúszót 0,45 $\mu \mathrm{m}$ pórusméretű Millex HV filter (Millipore) segítségével sterilre szürtük. A feülúszót ezután $2 \mathrm{ml}$ térfogatúra töményítettük (4000 g 30 perc), $10 \mathrm{kDa}$ Amicron Ultra -15 filter segítségével. Az enzimaktivitás detektálásához a Dabcyl-Glu-His-Val-Lys-Leu-Val-GluEDANS fluoreszcens szubsztrátot használtuk fel ( $5 \mathrm{mg} / \mathrm{ml}$, DMSO-ban oldva), melyet Olga Hruskova-Heidingsfeldova csoportja bocsátott rendelkezésünkre.

A Sapp1 és Sapp2 fehérjék proteolitikus reakciója $150 \mu$ l végtérfogatban történt, amely $5 \mu 1$ fluoreszcens szubsztrát törzsoldatot, $20 \mu$ koncentrált felülúszót (kontrollként tisztított Sapp1 fehérjét, $0,05 \mathrm{mg} / \mathrm{ml}$ ) tartalmazott. A tisztított Sapp1 fehérjét szintén Olga HruskovaHeidingsfeldova csoportja bocsátotta rendelkezésünkre. A reakciót $100 \mathrm{mM}$ nátrium-acetát pufferrel $(\mathrm{Ph}=3,75)$ egészítettük ki $150 \mu \mathrm{l}$-re, majd sötétben $37{ }^{\circ} \mathrm{C}$-on egy éjszakán át inkubáltuk. A reakció leállítását $20 \mu 20 \%$ trifluor-ecetsavval (TFA) végeztük. A HPLC analízis körülményei a következőek voltak: Phenomenex Prodigy c18 250*4.6 5 mikron-os oszlop, „A” eluens: víz+0,1\% trifluor ecetsav, „B” eluens: acetonitril $+0.1 \%$ trifluor ecetsav, áramlási sebesség: $1 \mathrm{ml} /$ perc, oszlop hőmérséklete: $30^{\circ} \mathrm{C}$, gerjesztési hullámhossz: $360 \mathrm{~nm}$, emissziós hullámhossz: $480 \mathrm{~nm}$. A kiértékelést végző szoftver: Shimadzu CLASS-VP 5.032.

\subsection{Virulencia vizsgálatok}

Szérumérzékenység vizsgálata: A vad típusú, valamint a $\Delta \Delta$ sappla, $\Delta \Delta \operatorname{sapp} 1 \mathrm{~b}, \Delta \Delta$ sappla$\Delta \Delta s a p p 1 b$ valamit a $\Delta \Delta s a p p 1 a-\Delta \Delta s a p p 1 b-\Delta \Delta s a p p 2$ törzseket YPD-PS tápoldatban $30{ }^{\circ} \mathrm{C}$-on, 200 rpm rázatás mellett egy éjszakán át tenyésztettük. Másnap a törzseket 1x PBS-ben mostuk, majd 5-5 $\mathrm{ml} 20 \%$ intakt, vagy hővel inaktivált $\left(56^{\circ} \mathrm{C}, 30\right.$ perc) humán szérum tartalmú, 1x PBS-el kiegészített tápközegbe oltottuk a törzseket, $1,5^{*} 10^{5}$-es sejtszámban. A törzseket ezután $30{ }^{\circ} \mathrm{C}$-on 200 rpm rázatás mellett inkubáltuk. $0,8,12,24$ és 48 óra után mintát vettünk a tenyészetekből, melyeket a megfelelő hígítás mellett YPD-PS táptalajra szélesztettünk. A csészéket 2 napig $30{ }^{\circ} \mathrm{C}$-on inkubáltuk, majd CFU meghatározást végeztünk.

Ölési hatásfok meghatározása: A PBMC illetve ezekből differenciáltatott primer makrofág sejteket 96 mintahelyes tenyésztőedényben fertőztük C. parapsilosis GA1 vad típusú valamint deléciós törzsekkel 1:5 arányban, három technikai párhuzamost alkalmazva. A fertőzéssel párhuzamosan fagocitákat nem, kizárólag PBMC vagy PBMC-DM tápoldatot tartalmazó kontroll mintahelyekbe élesztő szuszpenziót pipettáztunk a fertőzéshez használt mennyiségben és térfogatban. A fertőzés előtt a humán sejteken tápoldatot cseréltünk, amely tápoldatot $37{ }^{\circ} \mathrm{C}$-ra előmelegítettünk. A fertőzéshez használt gomba sejtszámot szintén a 
humán sejteknek megfelelő tápoldatban hígítottuk, majd $20 \mu 1$ térfogatban adtuk a gazda sejtekhez. 3 óra inkubációt $\left(37^{\circ} \mathrm{C}, 100 \%\right.$ relatív páratartalom, $5 \% \mathrm{CO}_{2}$ tenzió) követően a tenyésztőedényt jégre helyeztük és minden további lépést jégen végeztünk, megakadályozandó a további fagocitózist valamint az élesztők további osztódását. A tápoldattal a letapadt gazda illetve gomba sejteket felszuszpendáltuk, majd kétszer $200 \mu 1$ jéghideg steril desztillált vízzel átmostuk a mintahelyeket. A szuszpenziót mikrocentrifuga csövekbe gyüjtöttük, és fecskendőre illesztett $27 \mathrm{G}$ vagy $29 \mathrm{G}$ jelü injekciós tü segítségével feltártuk a fagocitákat illetve elválasztottuk az esetleges sarjsejteket. Az élesztő sejtszám meghatározását és az ez alapján kalkulált hígítást követően a szuszpenzióból $50 \mu 1-\mathrm{t}$ szélesztettünk YPD-PS táptalajra, amelyeket két napon keresztül $30^{\circ} \mathrm{C}$-on inkubáltunk. A telepszámokat meghatároztuk, átlagoltuk és az alábbi formula felhasználásával kiszámítottuk az eliminált élesztők százalékos arányát: [(Átlag Kontroll - Átlag Fertỏzés)/Átlag Kontroll] x 100. A kísérlet során három biológiai - (három mintahely) és három technikai (három csésze/1 mintahely) párhuzamost alkalmaztunk.

Gazda sejtek károsodásának meghatározása: Humán PBMC sejtekből differenciáltatott primer makrofág sejtek gomba általi károsítását a Citotoxicity Detection Kit (LDH), (Roche) segítségével végeztük, a gyártó utasításainak megfelelően. A laktát dehidrogenáz az emlős sejtekben megtalálható, intracelluláris enzim. A koinkubáció során felszabaduló enzim mennyisége arányos a gazdasejtek károsodásának mértékével. A gazda sejteket ebben az esetben is 1:5 arányban fertőztük vad típusú, valamint deléciós törzsekkel, három technikai párhuzamost alkalmazva. Kontrollként nem fertőzött humán sejteket, valamint tiszta makrofág tápoldatot tartalmazó mintákat alkalmaztunk. A humán sejtek fertőzését $1 \mathrm{ml}$ végtérfogatnyi tápoldatban végeztük, majd 24 és 48 óra inkubációt $\left(37{ }^{\circ} \mathrm{C}, 100 \%\right.$ relatív páratartalom, $5 \% \mathrm{CO}_{2}$ tenzió) követően feülúszót gyüjtöttünk, majd a reakciót követően, a tiszta tápoldatot tartalmazó mintákat felhasználva fotometriás módszerrel meghatároztuk az egyes törzsekhez tartozó minták relatív LDH aktivitását, a gyártó utasításainak megfelelően.

Lizoszóma - fagoszóma kolokalizációs vizsgálat: A lizoszómákat Lysotracker Red (50 nM) (Invitrogen), az élesztőket calcofluor white (Sigma) (50 ng/ml) fluoreszcens festékkel tettük láthatóvá. A gombákat egy éjszakán át tenyésztettük YPD-PS-ben, kétszer mostuk PBS-sel (3000 rpm, 5 perc), majd $100 \mu 1$ sejtszuszpenziót $1 \mu 1$ calcofluor withe festékkel festettük 15 percen át szobahőn, fénytől védve. A szuszpenziót az inkubációs idő lejártát követően kétszer mostuk 1xPBS-ben, majd a sejtszámot a kívánt koncentrációra állítottuk be. A korongon 
nevelt humán makrofág sejteket ötszörös mennyiségű élesztő sejttel fertőztük. Az inkubáció időtartama ez esetben is 3 óra volt $\left(37^{\circ} \mathrm{C}, 100 \%\right.$ relatív páratartalom, $5 \% \mathrm{CO}_{2}$ tenzió). $\mathrm{Az}$ inkubációt követően a mintahelyekben lévő tápoldatot, óvatos PBS-es mosást követően, 1x-es PBS-ben oldott $50 \mathrm{nM}$ koncentrációjú Lysotracker Red oldatra cseréltük. Harminc perces inkubációt követően az oldatot eltávolítottuk, a mintákat kétszer mostuk 1x-es PBS-sel, majd PBS-ben, átlátszó körömlakk segítségével tárgylemezre rögzítettük. A mintákat Olympus DP72 fluoreszcens mikroszkóppal vizsgáltuk.

Fagocitózis vizsgálat: A primer humán makrofágok fagocitáló képességének analíziséhez Alexa Fluor 647 karboxilsav, szukcinimidil észter (Life Technologies), illetve fluoreszceinizotiocianát (FITC) (Life Technologies) fluoreszcens festékkel jelölt élesztőket használtunk. Alexa Fluor 647 karboxilsav, szukcinimidil észter alkalmazása esetén az élesztő sejteket egy éjszakán át $30{ }^{\circ} \mathrm{C}$-on $200 \mathrm{rpm}$ rázatás mellett $2 \mathrm{ml}$ YPD-PS tápoldatban neveltük. Másnap a sejteket kétszer mostuk 1x PBS-ben (3000 rpm 5 perc), majd $500 \mu 1$ 1x PBS-ben vettük fel öket. A szuszpenzióhoz $55 \mu 11 \mathrm{M}$-os nátrium-karbonátot adtunk $(\mathrm{pH}=10)$, valamint $10 \mu \mathrm{l}$ alexa fluor 647 festéket ( $1 \mathrm{mg} / \mathrm{ml}$, DMSO-ban oldva). 30 percig szobahőn, fénytől védve inkubáltuk, majd háromszor 1x PBS-ben mostuk, végül $200 \mu$ PBS-ben vettük fel. Fluoreszcein-izotiocianát alkalmazása esetén a gombákat egy éjszakán át tenyésztettük YPDPS-ben, kétszer mostuk PBS-sel (3000 rpm, 5 perc), majd FITC-pufferben vettük fel, amelyhez $25 \mu \mathrm{g} / \mathrm{ml}$ végkoncentrációban FITC festéket adtunk. A szuszpenziót fénytől elzártan $200 \mathrm{rpm}$ rázatás mellett inkubáltuk egy éjszakán át $30^{\circ} \mathrm{C}$-on. A gombákat $5 \mathrm{x}$ mostuk 1x-es PBS-sel, majd a kívánt sejtszámra állítottuk be a szuszpenzió koncentrációját. Ezeket primer humán makrofágokkal inkubáltuk 12 mintahelyes tenyésztőedényben 120 percig 1:5 gazda:patogén arányban. Az inkubációs idő letelte után a mintahelyeket alaposan mostuk 1xes PBS-sel, majd mintahelyenként $500 \mu 37{ }^{\circ} \mathrm{C}$-ra előmelegített TrypLE Express-t (Life Technologies) mértünk a sejtekre, melyeket 45 percig $37{ }^{\circ} \mathrm{C}$-on inkubáltunk $\left(5 \% \mathrm{CO}_{2}, 100 \%\right.$ relatív páratartalom). Az inkubációs idő letelte után a sejteket szuszpenzióba vittük, a technikai párhuzamosokat egybemostuk, majd $2000 \mathrm{rpm}$ fordulaton 5 percig ülepítettük a sejteket, melyeket végül $300 \mu$ FACS pufferben vettünk fel. Az így előkészített mintákat FACSCalibur készülékkel és a mellékelt kiértékelő szoftverrel elemeztük.

Enzim kötött immunoszorbens assay (ELISA): Az enzimkötött immunoszorbens assay méréseket az RnD DuoSet ELISA Kit $(\mathrm{RnD})$ segítségével végeztük el, a gyártó utasításai szerint. A citokin (TNF $\alpha$, IL-6, IL-1 $\beta$ ) termelés vizsgálatához a primer humán makrofágokat 
1:5 arányban élesztő sejtekkel fertőztünk, $500 \mu$ végtérfogatban, két technikai párhuzamost alkalmazva. Az inkubáció időtartama 24 óra volt, amely idő letelte után felülúszókat gyüjtöttünk, melyeket felhasználásig $-20{ }^{\circ} \mathrm{C}$-on tároltunk.

\subsection{In vivo vizsgálatok}

Viaszmoly (Galleria melonella) lárvák fertőzése: A viaszmoly lárváinak fertőzésekor elsőként az optimális sejtszámot határoztuk meg. Ehhez az élesztő sejteket egy éjszakán át 30 ${ }^{\circ} \mathrm{C}$-on 200 rpm rázatás mellett $2 \mathrm{ml}$ YPD-PS tápoldatban neveltük. Másnap a sejteket kétszer mostuk 1xPBS-ben, majd a sejtszámot $10^{8} \mathrm{sejt} / \mathrm{ml}$ számúra állítottuk be, majd tízszeres hígításban, öt lépcsőben hígítottuk a szuszpenziót. A sejtek injektálásához $10 \mu$ térfogatú szuszpenziót alkalmaztunk. A fertőzéshez használni kívánt optimális sejtkoncentráció megállapítása után tizes csoportokban fertőztük a lárvákat, a következők szerint: 1x PBS-el injektált csoport, vad típusú törzssel fertőzött csoport, valamint a deléciós törzssel fertőzött csoport. A fertőzést követően $30{ }^{\circ} \mathrm{C}$-on tartottuk a lárvákat, naponta vizsgáltuk a túlélési rátát, két héten keresztül.

\subsection{Sejtfalösszetétel vizsgálatok}

Sejtfali kitin, kitin oligomer, $\beta-1,3$ glükán és mannán tartalom meghatározása: A sejtfalban megtalálható szénhidrát polimerek és oligomerek meghatározásához a $30^{\circ} \mathrm{C}$-on YPD tápközegben felnövesztett élesztő sejteket 1x PBS-ben mostuk, majd 2\% paraformaldehidet tartalmazó 1x PBS-ben egy órán keresztül szobahőn fixáltuk. $\mathrm{Az}$ inkubációs idő után a sejteket 1\% BSA-t tartalmazó 1x PBS-ben inkubáltuktovábbi egy órán keresztül, majd 1x PBS-ben mostuk.

A sejtfal $\beta$-glükán tartalmának meghatározásához $10^{5}$ számú fixált sejtet $0,1 \mathrm{mg} / \mathrm{ml}$ koncentrációjú anilinkék (Arcolor, Sao Paulo, SP, Brazil) festékkel 5 percig szobahőn festettük., majd a sejteket 1x PBS-el mostuk. A teljes fluoreszencia meghatározását Spectra Max Gemini XPS spektrofluoriméterrel (Molecular Devices) végeztük. Gerjesztési hullámhosszként 400nm-t alkalmaztunk, míg az emissziós hullámhosszt 460nm-en detektáltuk. Kontrollként festetlen mintát alkalmaztunk.

A sejtfali kitin tartalom meghatározásához $25 \mu \mathrm{M}$ koncentrációjú Calcofluor white (Invitrogen, Life techonologies), a sejtfali kitin oligomerek mennyiségének meghatározásához $50 \mu \mathrm{g} / \mathrm{ml}$ koncentrációjú Alexa fluor 594-konjugált WGA (Molecular Probes), míg a sejtfal 
ג-mannán tartalmának meghatározásához $100 \mu \mathrm{g} / \mathrm{ml}$ koncentrációjú fluorescein-izothiocianát (FITC) konjugált ConA (Sigma-Aldrich) fluoreszcens festékeket alkalmaztunk. A fixált sejtek $10^{6}$ mennyiségét $1 \mathrm{ml}$, a megfelelő fluoreszcens festéket tartalmazó 1x PBS-ben 30 percig szobahőn inkubáltuk, majd 1x PBS-ben háromszor mostuk (3000rpm, 5 perc). A festett sejteket Zeiss Observer Z.1 fluoreszcens mikroszkóppal vizsgáltuk, a képeket ZENN 2011 (Zeiss) szoftverrel rögzítettük. A képek elemzését az analySIS (Soft Image System) és az ImageJ programokkal végeztük.

Extracelluláris vezikula izoláció: Az YPD tápközegben felnövesztett tenyészetek felülúszóit két lépésben sejtmentesre centrifugáltuk (1. lépés: $4000 \mathrm{~g}, 15$ perc, $4^{\circ} \mathrm{C}, 2$. lépés: $15.000 \mathrm{~g}, 15$ perc, $4^{\circ} \mathrm{C}$ ). A sejtmentes felülúszót $100 \mathrm{kDa}$-os Amicron ultraszürőn koncentráltuk, majd a koncentrált felülúszót ismét két lépésben centrifugáltuk (1. lépés: $4000 \mathrm{~g}, 15$ perc, $4^{\circ} \mathrm{C}, 2$. lépés: $15.000 \mathrm{~g}, 15$ perc, $\left.4^{\circ} \mathrm{C}\right)$. Az így kapott, tisztított felülúszót ultracentrifugálásnak vetettük alá (100.000g, 60 perc, $\left.4^{\circ} \mathrm{C}\right)$. Az így kapott pelletet 0,1 M Tris-t tartalmazó 1x PBS-el mostuk. $\mathrm{Az}$ extravezikuláris glükoxilomannán szennyeződés kiküszöbölése érdekében a mintát cianogén-bromid aktivált, monoklonális glükoxilomannán kötött Sepharose oszlopon tisztítottuk. Az átfolyó frakciót 100.000 g-vel 60 percig centrifugáltuk. Az extracelluláris vezikula frakció koncentrációjának meghatározását az Amplex Red Sterol Assay Kit (Molecular Probes, Life Technologies, Grand 6 Island, NY, USA) segítségével végeztük, a gyártó utasításainak megfelelően.

Az extracelluláris vezikulák méretének meghatározása: Az extracelluláris vezikulák átmérőjének meghatározását 90Plus/BI-MAS Multi Angle Particle Sizing analyzer (Brookhaven Instruments Corp., Holtsville, NY, USA) berendezéssel határoztuk meg. A mérés $25^{\circ} \mathrm{C}$-on történt. Az extracelluláris vezikulák méret szerinti megoszlásának analíziséhez a non-negatively constrained least squares algoritmust használtuk.

Scanning elektronmikroszkópia: A C. parapsilosis vad típusú és deléciós mutáns törzseinek scanning elektronmikroszkópos vizsgálatához $10^{7}$ sejtet használtunk fel, melyeket poli Llizinnel bevont fedőlemezen rögzítettünk. A sejteket 1x PBS-ben mostuk, majd a mintákat $2,5 \%$ glutáraldehidet tartalmazó Sorenson-pufferben $(\mathrm{pH}=7,5)$ egy éjszakán át $4{ }^{\circ} \mathrm{C}$-on fixáltuk. A szárítást felszálló alkoholsorral végeztük: 50\% etanol (2x15 perc, jégen), 70\% etanol ( $2 \times 15$ perc jégen), 80\% etanol (2x15 perc, jégen), 90\% etanol (2x15 perc, jégen), 95\% etanol ( $2 \times 15$ perc, jégen), abszolút etanol (2x15 perc, jégen). A fedőlemezeket ezután terc- 
butil alkohol : abszolút etanol 1:2, 1:1, 2:1 arányú keverékébe, majd 100\%-os terc-butil alkoholba helyeztük 1-1 órára szobahőmérsékleten. A mintákat végül tömény terc-butil alkoholban $4{ }^{\circ} \mathrm{C}$-on megfagyasztottuk, és egy éjszakán át liofilizáltuk. Másnap a megfelelő alumínium hengerekre rögzítettük a korongokat, majd a szükséges aranyréteg felvitelét követően (Quorum Technologies SC 7620 'Mini') a mintákat JEOL JSM-5310 scanning elektronmikroszkóppal vizsgáltuk.

\subsection{Statisztikai analízis}

Az adatok kiértékelését és a különbségek szignifikanciájának kiszámítását ANOVA és páratlan T-teszt analízissel, a GrapPad Prism 6 szoftverrel végeztük. A különbségeket $\mathrm{P}<$ 0,05 értékek esetén tekintettük szignifikánsnak. 


\section{EREDMÉNYEK ÉS ÉRTÉKELÉSÜK}

\subsection{A C. parapsilosis Sapp1 fehérjének, valamint a szekretált aszpartil proteinázok általános szerepének virulenciában betöltött vizsgálata}

Bár munkánk kezdetén a $C$. parapsilosis Sapp1 fehérjéjének virulenciában betöltött szerepét vizsgáltuk, mégis a munka jobb megértésének érdekében jobbnak láttuk a $C$. parapsilosis Sapp1 fehérjének és a szekretált aszpartil proteinázok általános szerepének vizsgálatát egy fejezetben tárgyalni.

\subsubsection{A C. parapsilosis SAPP1 lokuszának in silico analízise}

Munkánk kezdetén a $C$. parapsilosis fö szekretált aszpartil proteináza, a Sapp1 virulenciában betöltött szerepét vizsgáltuk. Az ekkoriban a Sanger intézet C. parapsilosis „genome database” (www.sanger.ac.uk/sequencing/Candida/parapsilosis) honlapján rendelkezésünkre álló szekvencia adatok alapján elvégeztük a SAPP1 ORF in silico analízisét. Az analízis eredményeként sikeresen azonosítottunk két, identikus $2871 \mathrm{bp}$ méretü szekvenciarészt, egymástól $32 \mathrm{~kb}$ távolságra amely egy-egy kópiában tartalmazta a $S A P P 1$ ORF-et (1206bp). A duplikálódott szakaszban található SAPPl géneket SAPPla és SAPPlb néven különítettük el egymástól (8. ábra).

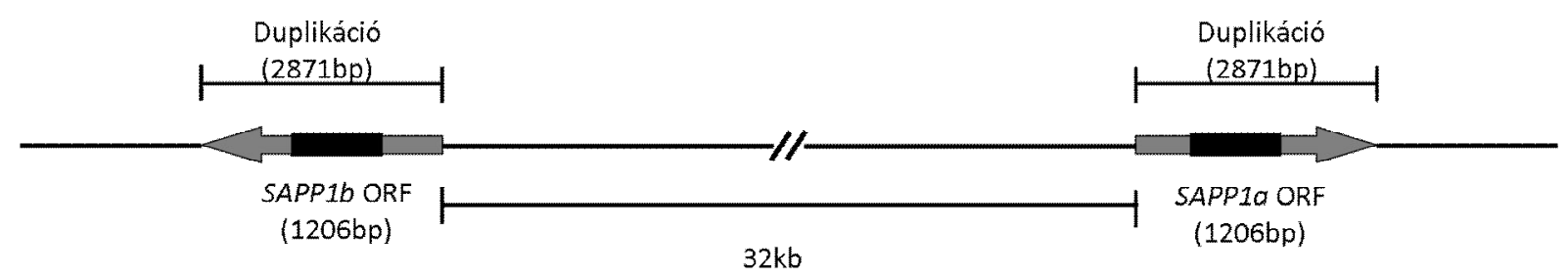

8. ábra

2871 bp méreü duplikálódott régió, egymástól 32kb távolságban, melyek a SAPP1 ORF-et tartalmazzák. A két kópiában jelen lévő $S A P P 1$ gént $S A P P l a$ és $S A P P 1 b$ néven különítettük el egymástól.

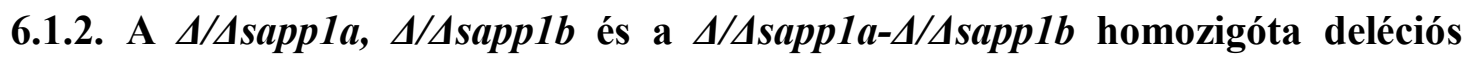
mutánsok létrehozása

Ahhoz, hogy a Sapp1 fehérje virulenciában betöltött szerepét vizsgáljuk, a $C$. parapsilosis GA1 jelű klinikai izolátumát, mint vad típusú törzset felhasználva a SAPP1 gének négy alléljának delécióját hajtottuk végre. Ezen munka során a $C$. albicans-ban kifejlesztett, majd $C$. parapsilosis-ra optimalizált caSAT1 flipper rendszer segítségével elöállítottunk homozigóta $\Delta / \Delta \operatorname{sapp} 1 a, \Delta / \Delta$ sapplb egyszeres és $\Delta / \Delta$ sapp $1 a-\Delta / \Delta$ sapplb dupla deléciós mutáns törzseket. 
A $\Delta /$ Ssappla homozigóta deléciós mutáns törzs esetén a pSFS2Sappla konstrukció segítségével a SAPPla gén delécióját hajtottuk végre. A deléciós mutáns létrehozása során Southern hibridizációval követtük a gén deléciójának folyamatát, a SAPPla gén upstream homológ régióját, mint hibridizációs próbát felhasználva. A Southern hibridizációhoz alkalmazott ClaI-BamHI kettős emésztés lehetővé tette a SAPPla és SAPPIb lokuszok egyértelmü elkülönítését

$(9$. ábra).

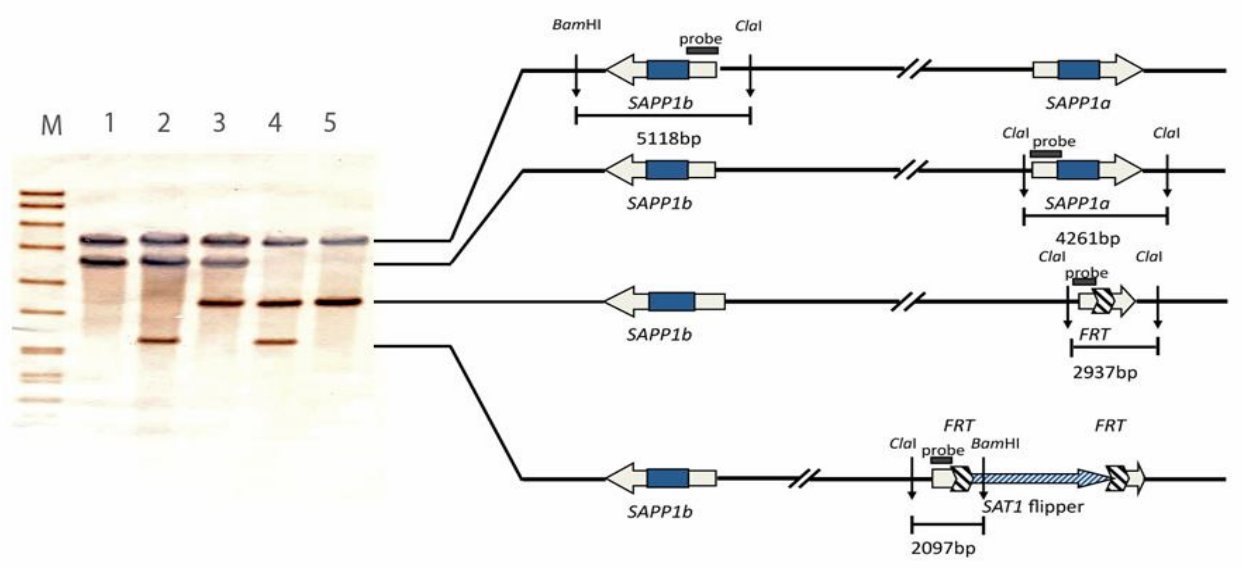

9.ábra

A $\Delta / \Delta$ sappla homozigóta deléciós mutáns létrehozása.

M: DNA Molecular Weight Marker VII, DIG-labeled (Roche), 1.: C. parapsilosis WT GA1, 2.: sapp 1aA::FRTSAT1-FRT/SAPP1a/SAPP1b/SAPP1b. 3.: sapp1aA::FRT/SAPP1a/SAPP1b/SAPP1b, 4.: sapp1aA::FRT/ sapplaA::FRT-SAT1-FRT/SAPP1b/SAPP1b, 5.: sapp1aA::FRT/ sapp1aA::FRT/SAPP1b/SAPP1b.

Ahhoz, hogy a SAPP1b lokusz delécióját végrehajtsuk, a pSFS2SAPP1a vektor alkalmazása sikertelennek bizonyult. Ezen probléma áthidalására a $S A P P 1 b$ lokusz sikeres deléciójának végrehajtása céljából egy ezen lokuszra specifikus pSFS2Sapp1b konstrukciót hoztunk létre, a duplikálódott régión kívül eső szekvenciák felhasználásával. Ezen konstrukció felhasználásával a vad típusú izolátum felhasználásával sikeresen létrehoztuk az organizmus homozigóta deléciós $\Delta / \Delta s a p p l b$ mutáns törzsét (10. ábra). 


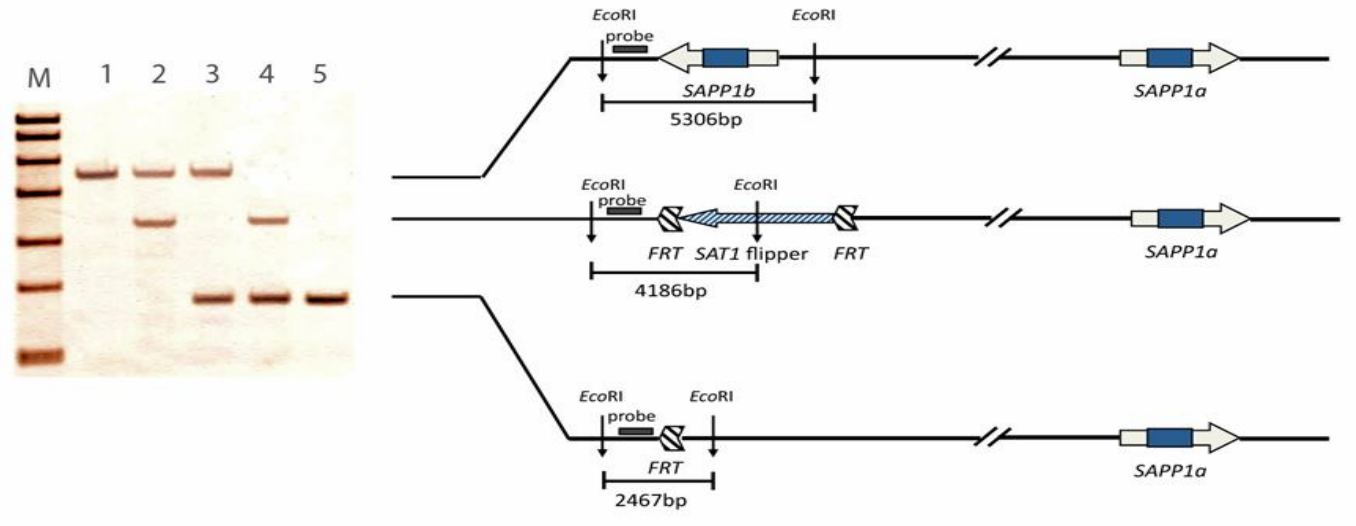

10. ábra

A $\Delta / \Delta$ sapp $1 b$ homozigóta deléciós mutáns létrehozása.

M: DNA Molecular Weight Marker VII, DIG-labeled (Roche), 1.: C. parapsilosis WT GA1, 2.: sapp1b4::FRTSAT1-FRT/SAPP1b/SAPPIa/SAPPIa, 3.: sapp1b4::FRT/SAPP1b/SAPPIa/SAPPla, 4.:

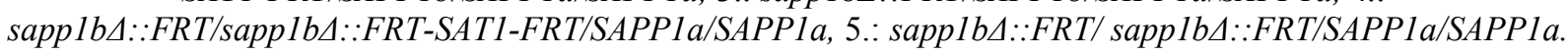

Az ily módon elóállított homozigóta deléciós $\Delta / \Delta$ sapp $1 b$ mutáns törzs segítségével állítottuk elö a $\Delta / \Delta$ sappla- $\Delta / \Delta \operatorname{sapplb}$ dupla deléciós mutáns törzset. Ennek elérése érdekében a $\Delta / \triangle$ sapplb deléciós törzset újra a pSFS2Sapp1a konstrukcióval transzformáltuk (11. ábra).

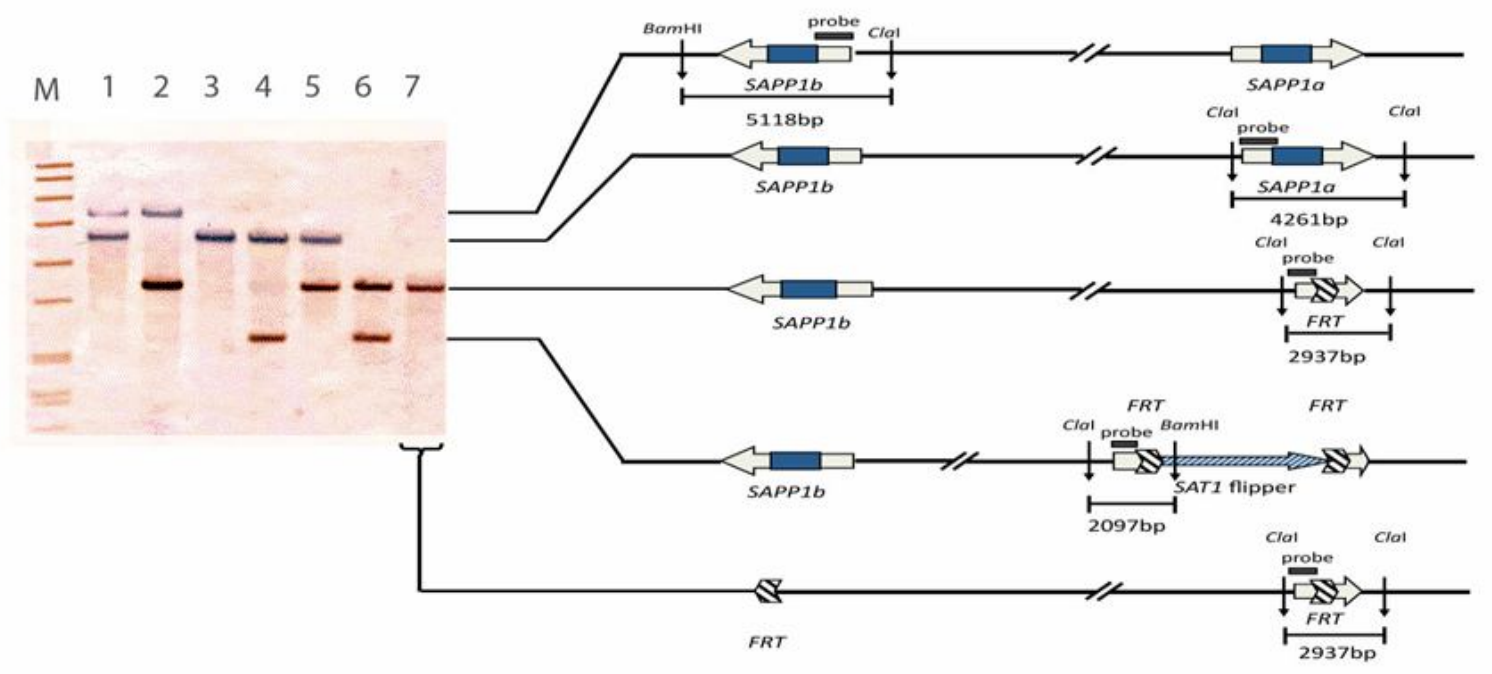

11. ábra

A homozigóta deléciós $\Delta / \Delta$ sappla- $\Delta / \Delta \operatorname{sapp} 1 b$ dupla deléciós mutáns törzs létrehozása.

M: DNA Molecular Weight Marker VII, DIG-labeled (Roche), 1.: C. parapsilosis WT GA1, 2.:

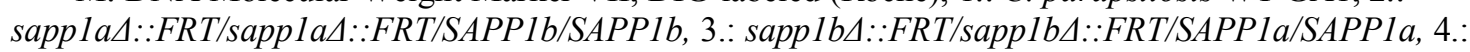
sapp1b4::FRT/sapp1b4::FRT/sappla::FRT-SAT1-FRT/SAPP1a, 5.: sapp1b4::FRT/sapp1b4::FRT/sapp1aA ::FRT/SAPP1a, 6.:

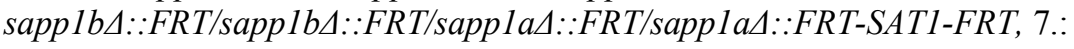

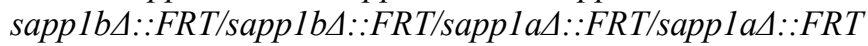




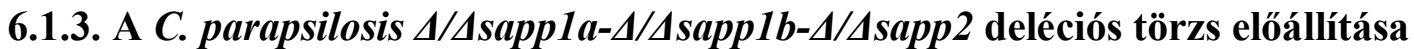

A C. parapsilosis $\Delta / \Delta$ sappla- $\Delta / \Delta$ sapplb deléciós törzs előállítása után, munkánk következő szakaszában célunk volt a $C$. parapsilosis által szekretált aszpartil proteinázok virulenciában betöltött szerepének általános jellemzése, így egy $\Delta / \Delta$ sappla- $\Delta / \Delta$ sapplb$\Delta / \Delta$ sapp2 deléciós törzs létrehozása. Ez a célkitüzés különösen indokolt annak fényében, hogy $C$. albicans esetében a Sap enzimek általános, virulenciában betöltött szerepének vizsgálata szinte lehetetlen, a nagyszámú szekretált proteinázt kódoló gén jelenléte miatt. Egy szekretált proteinázt nem termelő $C$. albicans törzs előállításához, legkevesebb 20 allél delécióját kellene megvalósítani, amely a jelenleg rendelkezésre álló genetikai manipulációs technikákkal kivitelezhetetlen feladat. C. parapsilosis-ban ezzel szemben csupán 2 szekretált proteinázt kódoló gén ismert, melyekről bizonyítottan funkcióképes fehérjék íródnak át és szekretálódnak (Hruskova-Heidingsfeldova és mtsai. 2009) így ezen gének deléciójával egy olyan modell organizmus volt létrehozható, amely szélesebb értelemben a szekretált proteinázok virulenciában és patogenitásban betöltött szerepének megértéséhez is hozzájárulhat. Ennek elérése érdekében a $S A P P 2$ gén delécióját hajtottuk végre a $C$. parapsilosis $\Delta / \Delta$ sappla- $\Delta / \Delta$ sapplb deléciós törzs hátterén. Érdekes módon már az első

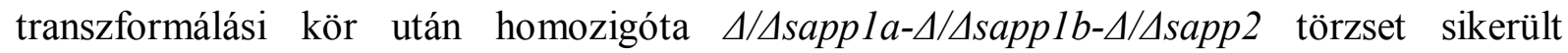

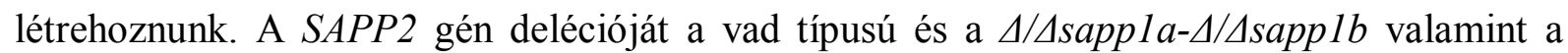
$\triangle / \triangle$ sappla- $\triangle / \triangle \operatorname{sapp} 1$ b- $\triangle / \triangle$ sapp 2 deléciós törzsek felhasználásával, a SAPP1 upstream és a $S A P P 2$ downstream jelölt hibridizációs próbák segítségével ellenőriztük (12. és 13. ábra).

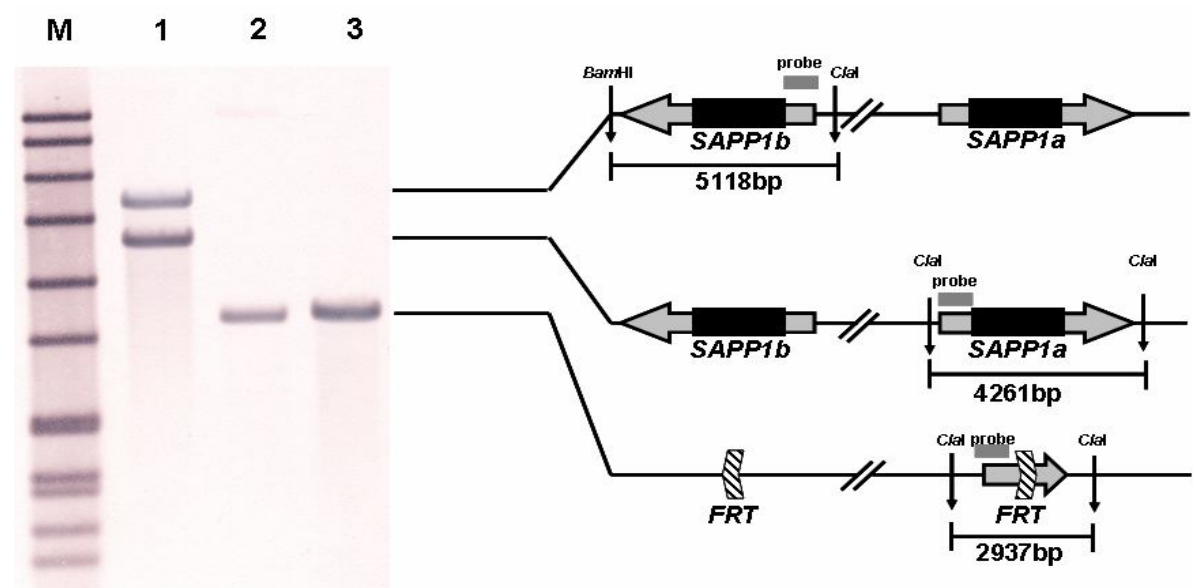

12. ábra

A $\triangle / \triangle$ sappla- $\Delta / \triangle$ sapp $1 b-\Delta / \triangle \operatorname{sapp} 2$ tripla deléciós törzs Southern analízise, $S A P P 1$ upstream hibridizációs próba felhasználásával, ClaI-BamHI kettős emésztést alkalmazva. M: DNA Molecular Weight Marker VII, DIGlabeled (Roche), 1.: C. parapsilosis WT GA1, 2.: sapp1b4::FRT/sapp1b4::FRT/sapp1aA $:: F R T /$ sapp1aA $:: F R T$,

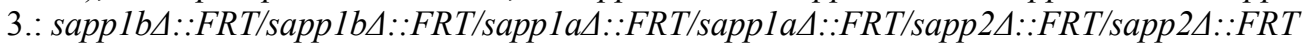




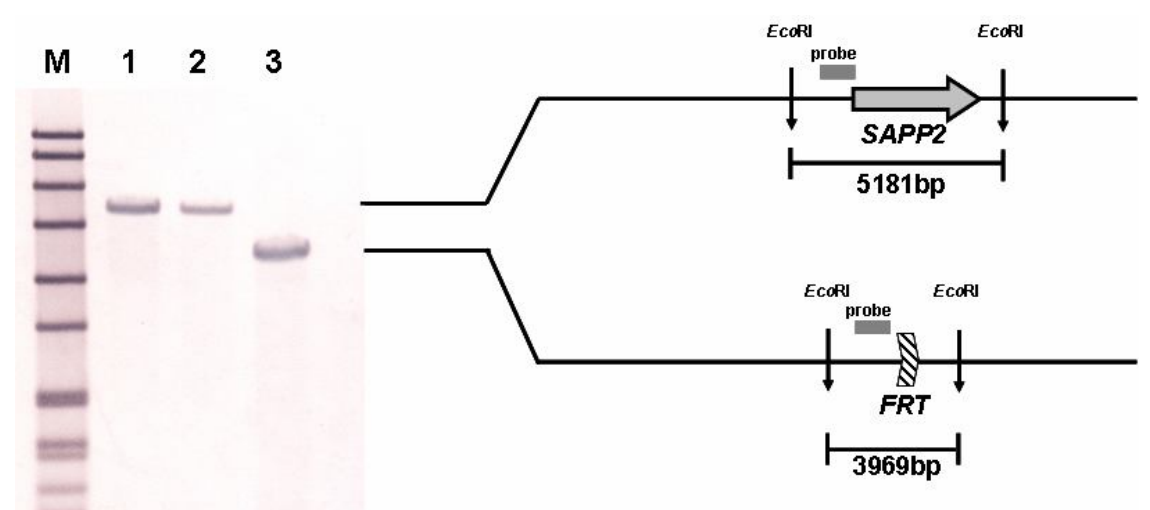

13. ábra

A $\triangle / \Delta$ sapp 1a- $\Delta / \Delta$ sapp $1 b-\Delta / \Delta$ sapp 2 tripla deléciós törzs Southern analízise, SAPP2 downstream hibridizációs próba felhasználásával, EcoRI emésztést alkalmazva. M: DNA Molecular Weight Marker VII, DIG-labeled (Roche), 1.: C. parapsilosis WT GA1, 2.: sapp1b4::FRT/sapp1b4::FRT/sapp1aA::FRT/sapp1aA ::FRT, 3.:

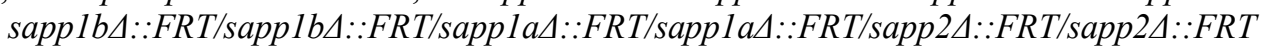

\subsubsection{A szekretált aszpartil proteináz gének kvantitatív in vitro}

\section{transzkripciójának vizsgálata}

Annak érdekében, hogy az előállított deléciós mutáns törzsek szekretált aszpartil proteináz génjeinek relatív transzkripciós szintjében bekövetkezett változásokat vizsgáljuk, kvantitatív real-time PCR (qRT-PCR) vizsgálatot végeztünk a vad típusú és deléciós mutáns törzsek bevonásával. Munkánk során vizsgáltuk a SAPP1 és $S A P P 2$ gének transzkripciójában bekövetkezett változásokat, amely gének bizonyítottan funkcióképes fehérjét kódolnak (Hruskova-Heidingsfeldova és mtsai. 2009). Vizsgáltuk továbbá a SAPP3 gén transzkripciójának változását is, amely gén termékét nem sikerült azonosítani, ám kollaborátorunk, Dr. Olga Hruskova-Heidingsfeldova jelezte, hogy jövőbeli tervei közt szerepel ezen gén által kódolt fehérje azonosítása és jellemzése is(14. és 15. ábra). A transzkripciós változások követéséhez a vad típusú és mutáns törzseket proteináz termelést indukáló ( $1 \mathrm{x}$ YCB $+2 \% \mathrm{BSA}$ ) és nem indukáló (YPD) médiumban egy éjszakán át, $30{ }^{\circ} \mathrm{C}$-on tenyésztettük. A vad típusú törzs esetén nem induktív körülmények között (YPD) mind a $S A P P 1$ mind a $S A P P 2$ és $S A P P 3$ gének alacsony szintü transzkripciója megfigyelhető volt. A proteináz termelést indukáló médiumban tenyésztett vad típusú minta esetén a SAPP1 gén transzkriptum mennyisége nyolcvanszorosára nőtt az YPD médiumban nevelthez képest. A SAPP2 és SAPP3 gének esetén mintegy tizenötszörös indukció volt megfigyelhető. A $\triangle / \triangle$ sappla és $\triangle / \triangle$ sapplb homozigóta deléciós mutáns törzsek esetén a SAPP1 gén transzkripcióját vizsgálva a vad típusú törzshöz képest 50 \%-os csökkenés volt megfigyelhető az említett gén expressziójában, míg a SAPP2 gén expressziós szintjében nem volt változás . 
A $\triangle / \Delta$ sappla- $\Delta / \Delta$ sapp $1 b$ dupla deléciós mutáns törzs esetén nem volt detektálható SAPP1 génexpresszió, viszont a $S A P P 2$ gén expressziója szignifikánsan megemelkedett a vad típusú törzshöz képest, ami feltételezhetően egy visszacsatoló mechanizmus általi kompenzáció a proteináz termelésben, melyet a SAPP1 gének elvesztése váltott ki. A SAPP3 gén transzkripciós változását vizsgálva a $\Delta / \Delta$ sapplb, $\Delta / \Delta$ sapplb-4sappla és a $\Delta / \Delta$ sappla$\Delta / \Delta$ sapplb törzsek esetén a transzkripció szintje csaknem nullára esett vissza. Ezen jelenség magyarázatául szolgálhat, hogy a $S A P P 1 b$ lokusz deléciója a duplikálódott régiójának deléciójával volt kivitelezhető. A későbbi szekvencia analízis kiderítette, hogy a SAPP3 lokusz ezen szakasztól csupán mintegy 500 bázispár távolságban helyezkedik el, így a $S A P P 1 b$ deléciója valószínűsíthetően a $S A P P 3$ lokusz szabályozó régióját is érintette.

A

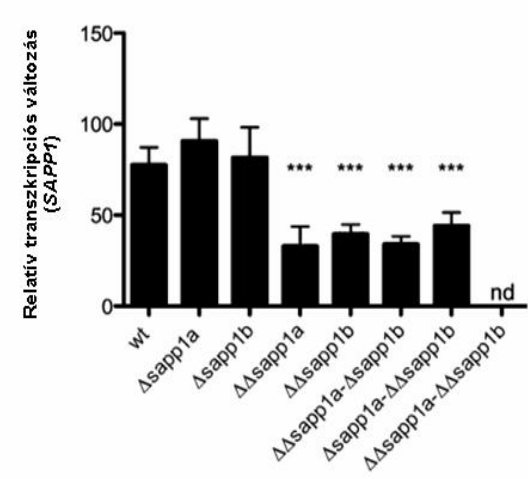

B

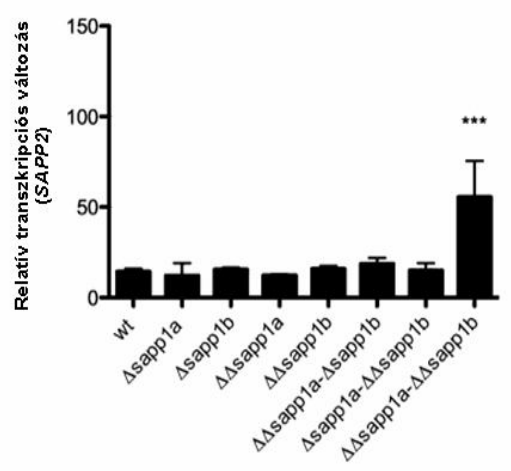

C

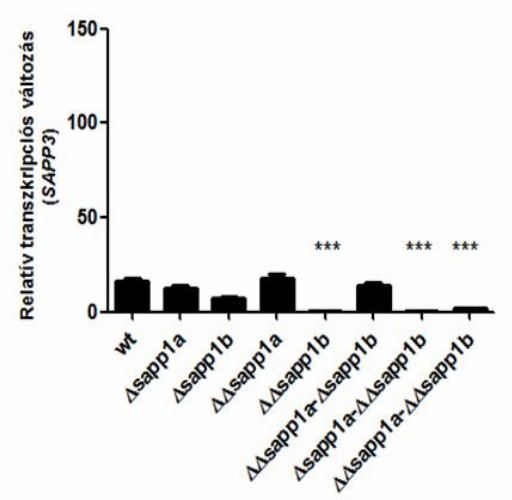

14. ábra

A SAPP1 (A), SAPP2 (B) és SAPP3 (C) gének transzkripciós változása in vitro kvantitatív real-time PCR analízise $S A P P 1$ deléciós mutáns törzsek esetén. A SAPP1 gén expressziója a $\triangle / \triangle \operatorname{sapp} 1 a, \Delta / \Delta$ sapplb, $\triangle / \Delta$ sappla- $\Delta$ sapp $1 b$ és a $\Delta / \Delta s a p p 1 b-\Delta$ sappla deléciós mutánsok esetén szignifikáns csökkenést mutatott $(* * *: \mathrm{P}<0,0001)$, míg a dupla deléciós mutáns esetén $S A P P 1$ génexpresszió nem volt megfigyelhetö. A SAPP2 gén transzkripciós változását vizsgálva a dupla deléciós mutáns esetén a gén transzkripciós szintje szignifikánsan megemelkedett (***:P $<0,0001)$. A $S A P P 3$ transzkripciója a $\triangle / \triangle$ sapp $1 b$, a $\Delta / \triangle$ sapp $1 b-\Delta$ sappla és a dupla deléciós mutáns törzsek esetén szignifikáns csökkenést mutatott $(* * *: \mathrm{P}<0,0001)$.

Hasonlóan a SAPP1 deléciós törzsekhez, vizsgáltuk az előállítottt $\triangle / \triangle$ sappla- $\Delta / \triangle$ sapplb$\triangle / \triangle$ sapp2 törzs esetén is a $S A P P$ gének transzkripciójának változását. A vad típusú törzs esetén a proteináz termelést indukáló médiumból származó mintában mintegy ötvenszeres

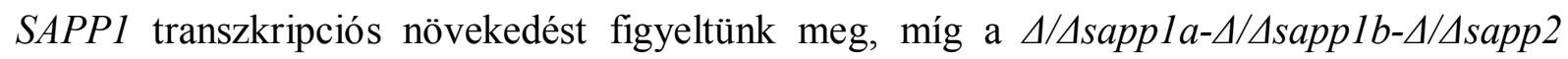
deléciós törzs esetén detektálható $S A P P 1$ génexpresszió nem volt megfigyelhető. A $S A P P 2$ gén transzkripciós változása esetén a vad típusú törzsben mintegy tizenötszörös növekedést figyeltünk meg, míg a $\Delta / \Delta$ sappla- $\Delta / \Delta \operatorname{sapp} 1 b-\Delta / \Delta \operatorname{sapp} 2$ deléciós törzs esetén detektálható $S A P P 2$ génexpresszió nem volt megfigyelhető. A $S A P P 3$ gén expressziója esetén a vad típusú 
törzsben mintegy nyolcszoros relatív transzkripciós szintet figyeltünk meg, míg a $\Delta / \Delta$ sappla$\triangle / \triangle$ sapp $1 b-\triangle / \triangle \operatorname{sapp} 2$ deléciós törzs esetén a $S A P P 3$ gén expressziója csupán mintegy 10\%-a volt az YPD tápközegben nevelt vad típusú kontrollhoz képest (15. ábra).

A

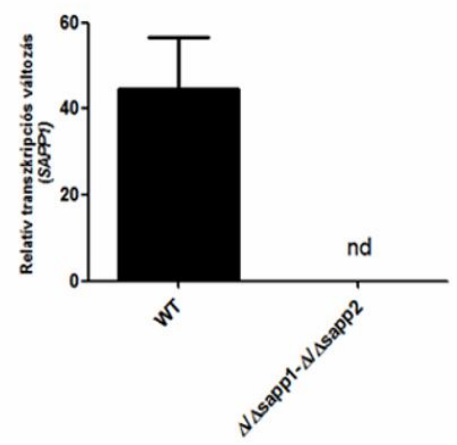

B

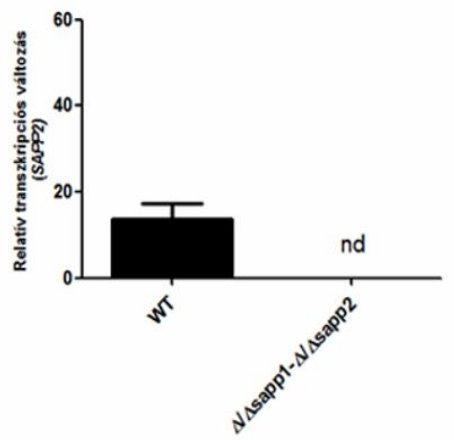

15. ábra
C

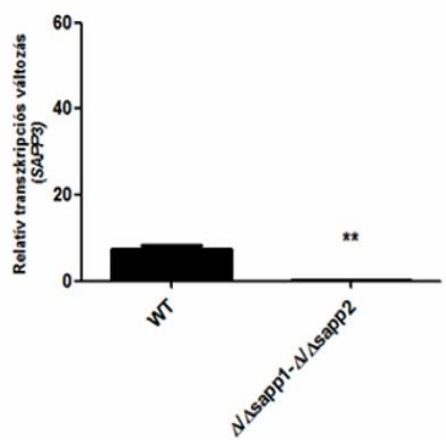

A $S A P P 1$ (A), SAPP2 (B) és SAPP3 (C) gének expressziójának in vitro kvantitatív real-time PCR analízise. A vad típusú törzshöz képest a $\triangle / \triangle$ sapp 1a- $\triangle / \triangle$ sapp 1 b- $\triangle / \triangle$ sapp 2 törzs esetén sem $S A P P 1$, sem $S A P P 2$ génexpresszió nem volt megfigyelhetö, míg a $S A P P 3$ gén expressziója a vad típushoz képest szignifikáns csökkenést mutatott $(* *: \mathrm{P}<0,001)$.

\subsubsection{Az extracelluláris proteináz aktivitás vizsgálata}

Egy előzetes tanulmány szerint a $C$. parapsilosis fó szekretált azpartil proteináza a Sapp1 fehérje (Hruskova-Heidingsfeldova és mtsai. 2009). Annak érdekében, hogy a proteináz aktivitás változását vizsgáljuk, a vad típusú és mutáns törzsek ( $\Delta$ sappla, $\Delta$ sapplb,

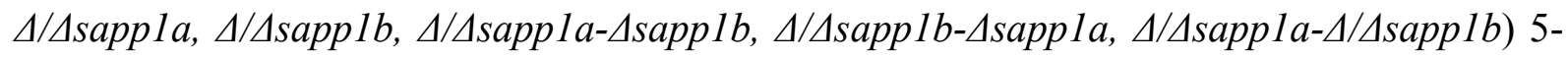
$5 \mu$ l-ét proteináz aktivitás detektálására alkalmas $(1 \mathrm{x} \quad \mathrm{YCB}+2 \% \mathrm{BSA})$ csészére csepegtettünk, $10^{8} / \mathrm{ml}$ sejtszámban. A csészéket $30{ }^{\circ} \mathrm{C}$-on 2 napig inkubáltuk, majd amidoblack festékkel festettük, végül mostuk. A mosást követően a feltisztulási zóna nagyságából következtettünk a proteináz aktivitás mértékére (16. ábra). Ez esetben a vad típusú, valamint a heterozigóta $\Delta s a p p l a$ és $\Delta s a p p 1 b$ törzsek proteináz aktivitása azonosnak

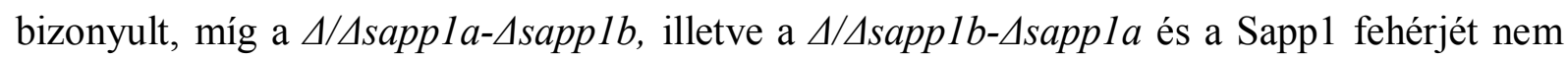
termelö $\Delta / \Delta$ sappla- $\Delta / \Delta$ sapplb törzs proteináz aktivitása szignifikáns csökkenést mutatott a vad típushoz képest. 

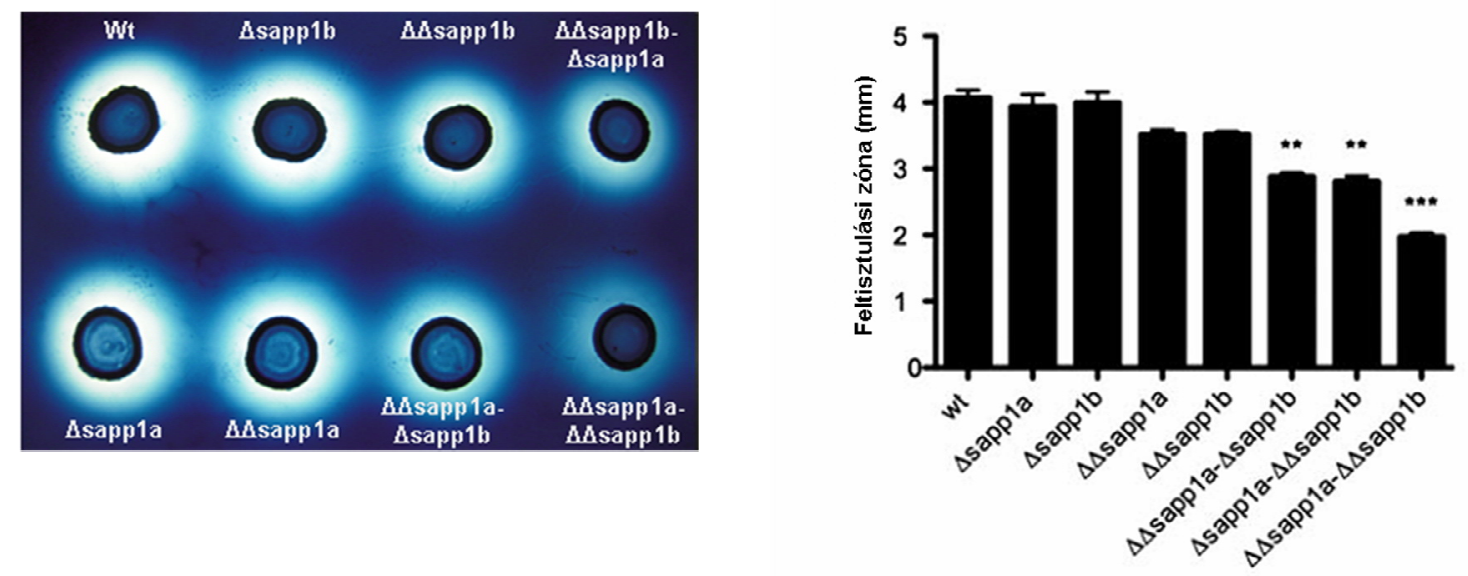

16. ábra

A vad típusú és $S A P P 1$ deléciós mutáns törzsek extracelluláris proteináz aktivitásainak detektálása. A

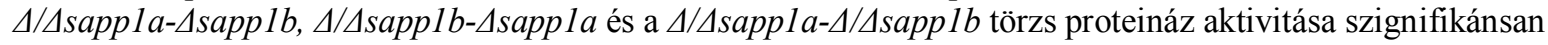
csökkent a vad típushoz képest (**: $\mathrm{P}<0,005$, ***: $\mathrm{P}<0,0001)$.

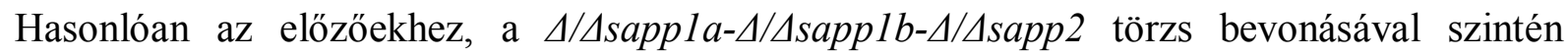
elvégeztük az extracelluláris proteináz termelés vizsgálatát. Ezen törzs mellett a vad típusú,

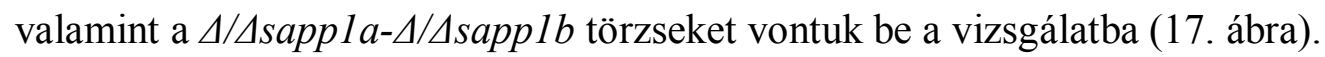
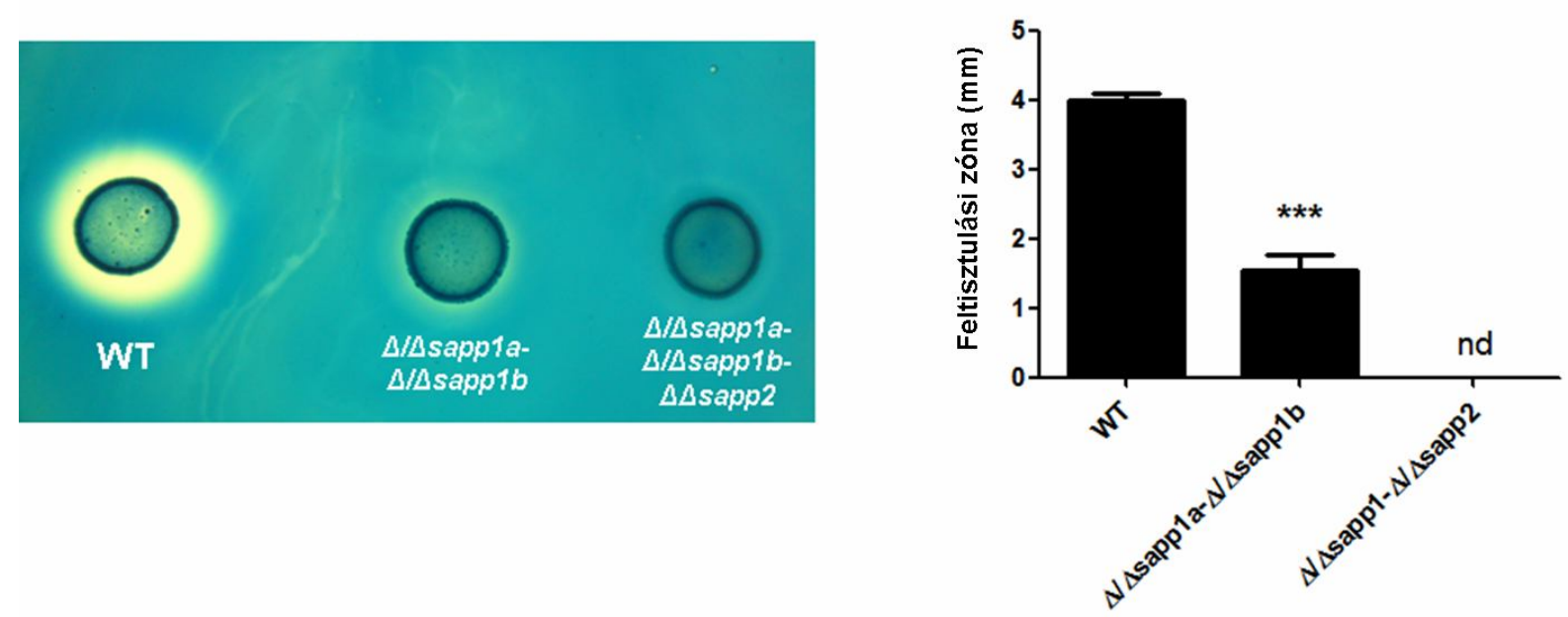

\section{7. ábra}

A vad típusú, valamint a $\Delta / \Delta$ sapp $1 a-\Delta / \Delta$ sapp 1 bés $\Delta / \Delta$ sappla- $\Delta / \Delta$ sapp 1 b- $\Delta / \Delta$ sapp 2 törzsek extracelluláris

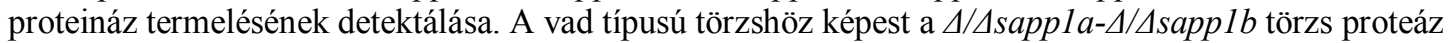
termelése szignifikánsan csökkent (***: $\mathrm{P}=0,0007)$, míg a $\Delta / \Delta$ sapp 1 - $-\Delta / \Delta$ sapp $1 b-\Delta / \Delta$ sapp2 törzs esetén detektálható extracelluláris proteináz aktivitás nem volt kimutatható.

A $\Delta / \Delta$ sappla- $\Delta / \Delta s a p p 1 b-\Delta / \Delta s a p p 2$ törzs esetén ezzel a módszerrel extracelluláris proteináz termelés nem volt detektálható. 


\subsubsection{A Sapp1 és Sapp2 enzimaktivitások kvantitatív vizsgálata}

Annak érdekében, hogy a termelödött Sapp1 és Sapp2 enzimek aktivitásáról felvilágosítást

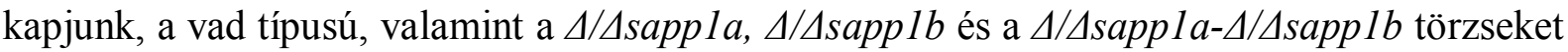
$1 \mathrm{x}$ YCB $+2 \%$ BSA médiumban $30{ }^{\circ} \mathrm{C}$-on egy éjszakán át növesztettük, majd a felülúszót 10 kDa-os ultraszürőn koncentráltuk. A DABCYL-Glu-His-Val-Lys-Leu-Val-Glu-EDANS specifikus fluoreszcens szubsztrát segítségével a Sapp1 és Sapp2 fehérjék aktivitásának mérése fluoreszcens detektorral felszerelt HPLC készüléken lehetséges. A szubsztráton belül a Sapp1 fehérje a Leu-Val, míg a Sapp2 fehérje a Lys-Leu kötéseket hasítja, a kapott hasítási termék a két fehérjére specifikus. A méréshez kontrollként tisztított Sapp1 enzimet használtunk fel. Mind a fluoreszcens szubsztrátot, mind a tisztított Sapp1 fehérjét Dr. Olga Hruskova-Heidingsfeldova bocsátotta rendelkezésünkre. A vizsgálatok során a vad típusú, valamint a $\Delta / \Delta \operatorname{sappla}$ és $\Delta / \Delta \operatorname{sapp} 1 b$ törzsek esetén két csúcsot lehetett megfigyelni, amelyek a Sapp1 és Sapp2 enzimek müködése során létrejött hasítási termékekre karakterisztikusak. A $\Delta / \Delta$ sappla- $\Delta / \Delta$ sapp 1 d dupla deléciós mutáns törzs esetén csak a Sapp2 enzimre specifikus csúcsot lehetett megfigyelni, valamint egy nem specifikus csúcsot, amelynek retenciós ideje nagyon közeli a Sapp1 müködése során létrehozott termékre jellemző csúcséval (18. ábra). Ezen megfigyelt, nem specifikus csúcs korábbi tanulmányokban azonosításra került (Dostal és mtsai. 2005, Hruskova-Heidingsfeldova és mtsai. 2009). Retenciós ideje nagyon közeli a Sapp1 fehérjére jellemző csúcséval, ám nem maradék Sapp1 fehérje aktivitásra utal. Dr. Olga Hruskova-Heidingsfeldova-val folytatott további konzultációk során egy előzetes vizsgálat szerint a Sapp2 fehérjének két különböző izoformája létezhet, amely a specificitásra is kihat, így az eddig nem specifikusnak gondolt csúcs valószínüsíthetően ezen másik Sapp2 izoforma müködése által jöhetett létre ( Olga Hruskova-Heidingsfeldova, nem közölt adat, személyes konzultáció). Bár Dr. Olga Hruskova-Heidingsfeldova rendelkezésre bocsátotta az általuk tisztított Sapp2 fehérjét is, melyet kontrollként kívántunk felhasználni, ám annak hasítási képe megegyezett a Sapp1 fehérje hasítási képével, így a Sapp2 további felhasználásától eltekintettünk, mivel új információt nem adott, ám ez az eredmény tovább erősíti annak lehetőségét, hogy a Sapp2 fehérjének két izoformája létezhet, eltérő specifitással. Ennek tanulmányozása jelenleg is folyik Dr. Olga Hruskova-Heidingsfeldova laboratóriumában. A vad típusú törzzsel összevetve a $\Delta / \Delta \operatorname{sappla}$ törzs esetén a Sapp1 fehérje aktivitása mintegy 45\%-al esett vissza, míg a $\Delta / \Delta s a p p 1 b$ törzs esetén a Sapp1 fehérje aktivitásának csökkenése 30\%-os volt. A dupla deléciós mutáns törzs esetén nem volt detektálható Sapp1 általi hasításra jellemző csúcs, amely enzim aktivitási szinten is igazolja a deléció meglétét. 
Ugyanezen törzs esetén a Sapp2 fehérje aktivitásában 50\%-os növekedés volt megfigyelhető, amely megerősíti a qRT-PCR vizsgálat által felfedezett kompenzációs mechanizmus meglétét.

A

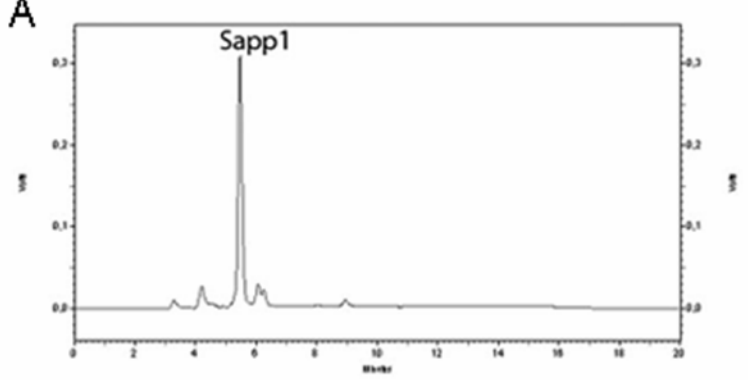

C

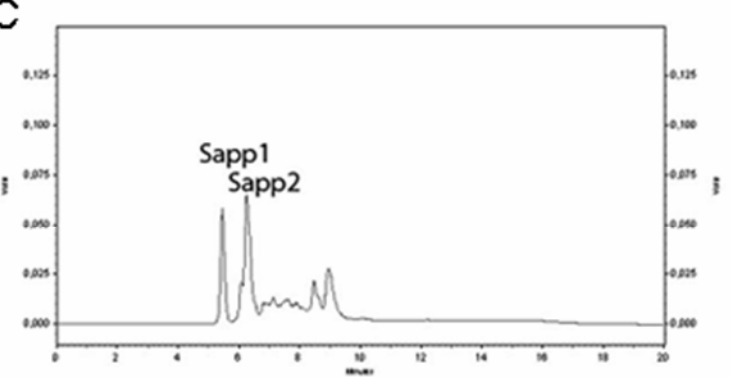

E

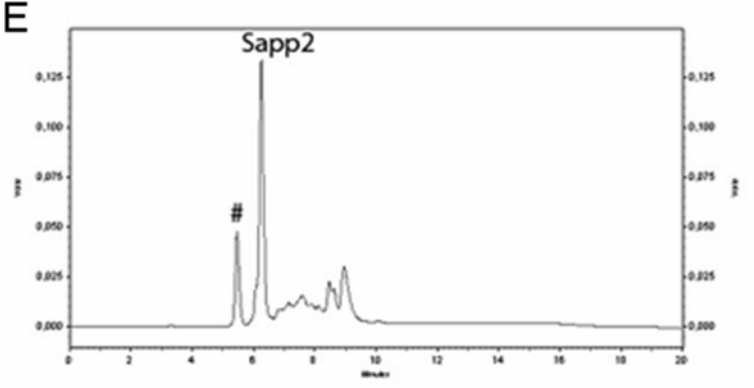

B

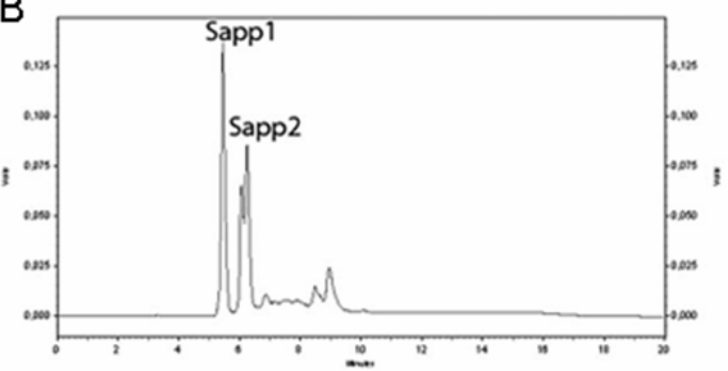

D

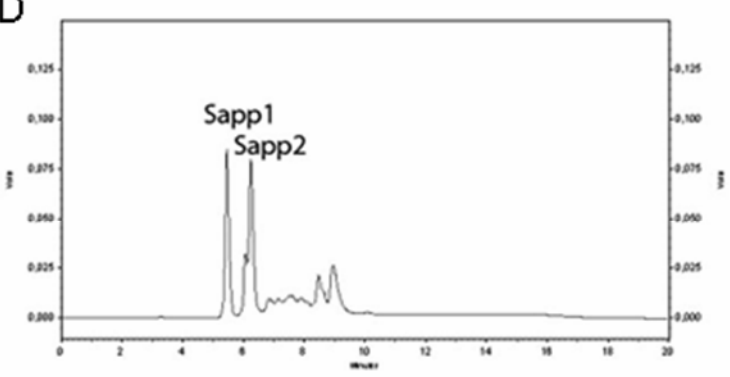

$\mathrm{F}$

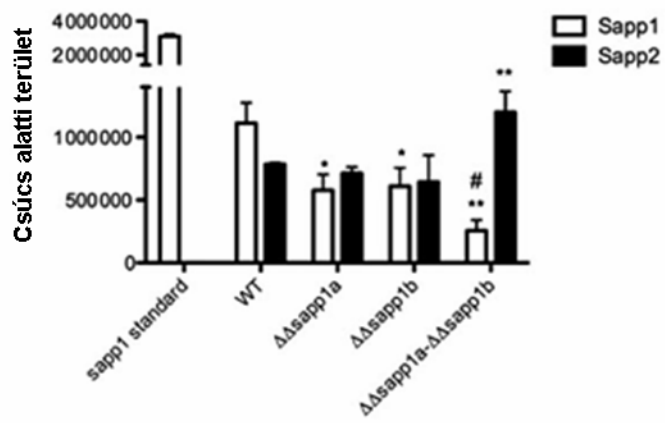

18. ábra

A Sapp1 és Sapp2 fehérjék aktivitásának kvantitatív HPLC analízise. A: a tisztított Sapp1 fehérje aktivitásának kimutatása. B: C. parapsilosis vad típusú törzs felülúszójának Sapp1 és Sapp2 enzimaktivitása. C: a $\Delta / \Delta$ sappla, D: a $\Delta / \Delta \operatorname{sapp} 1 b$, E: a $\Delta / \Delta \operatorname{sappla}$ - $\Delta / \Delta$ sapp $1 b$ törzs felülúszójának Sapp1 és Sapp2 enzimaktivitása. F: Az egyes törzsek enzimaktivitásainak összefoglaló diagramja. \#: nem Sapp1 specifikus csúcs (valószínüsíthetően a Sapp2 egyik izoformájának müködése következtében lérejövő jel). (**: $\mathrm{P}<0,005, *: \mathrm{P}<0,05)$.

A vad típusú, valamint a $\Delta / \Delta$ sappla- $\Delta / \Delta$ sapplb és $\Delta / \Delta$ sapp $1 a-\Delta / \Delta \operatorname{sapp} 1$ b- $\Delta / \Delta$ sapp 2 törzsek bevonásával szintén elvégeztük a Sapp1 és Sapp2 fehérjék enzimaktivitásának kvantitatív analízisét. Kontrollkét ebben az esetben is tisztított Sapp1 enzimet használtunk (19. ábra). A

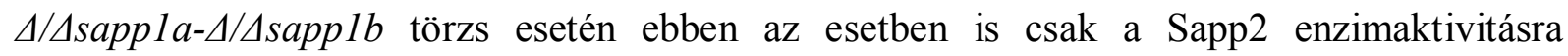
specifikus csúcsot lehetett megfigyelni. Ezen mutáns esetén újra megfigyelhető volt a Sapp2 fehérje termelődésének illetve aktivitásának szignifikáns mértékü emelkedése. A $4 / \Delta$ sappla$\Delta / \Delta$ sapp 1 b- $\Delta / \Delta$ sapp 2 törzs esetén a Sapp1 fehérjére karakterisztikus csúcsot nem tudtunk 
megfigyelni. A Sapp2 fehérjére karakterisztikus csúcs szintén eltűnt ezen mutáns esetében. Olga Hruskova-Heidingsfeldova és kollégái által azonosított (Dostal és mtsai. 2005, Hruskova-Heidingsfeldova és mtsai. 2009), valamint a $\Delta / \Delta$ sapp $1 a-\Delta / \Delta$ sapp $1 b$ törzs esetében általunk is megfigyelt nem karakterisztikus csúcs a $\Delta / \Delta$ sapp $1 a-\Delta / \Delta \operatorname{sapp} 1 b-\Delta / \Delta$ sapp 2 törzs esetén szintén eltünt. Ez az eredmény megerősíti azt, hogy ezen csúcs valójában a Sapp2 fehérje másik izoformájának terméke lehet, amely izoforma eltérő szubsztrát specifitással rendelkezik.

A

B
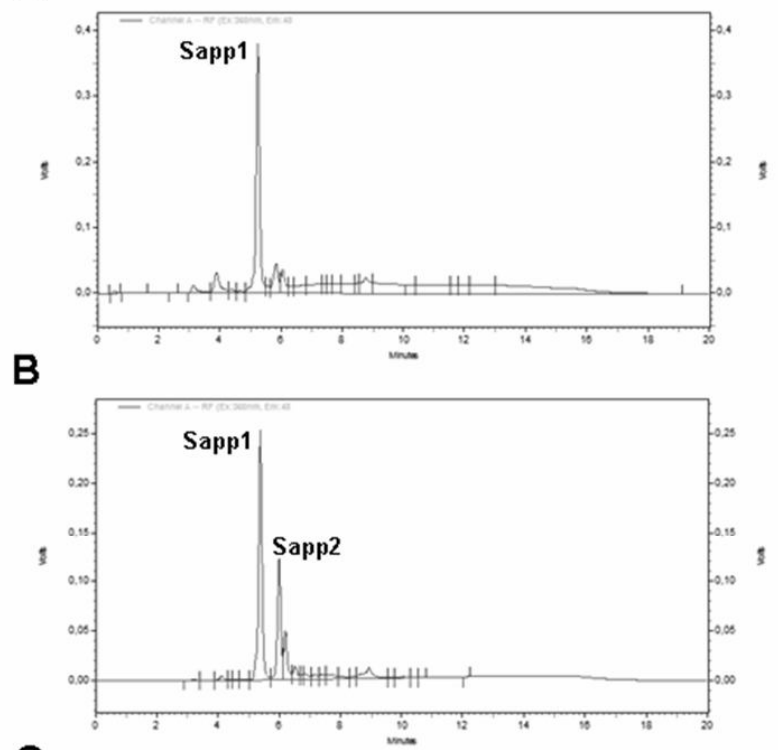

C

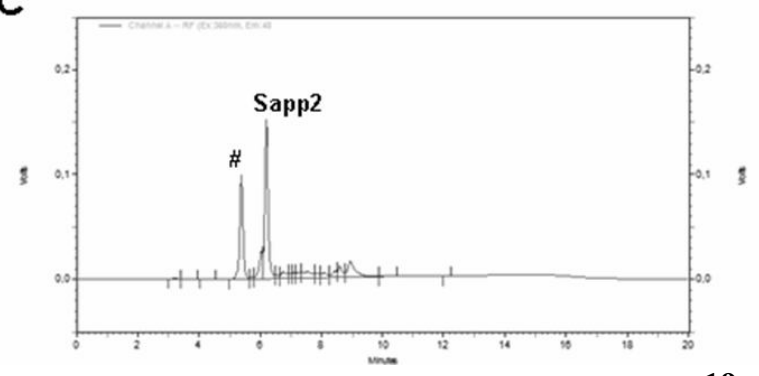

D

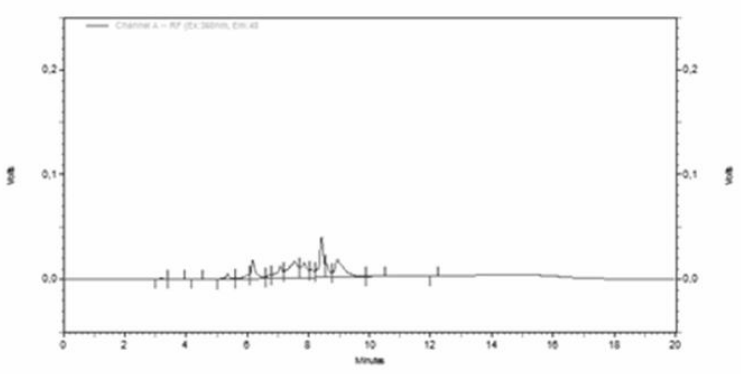

E

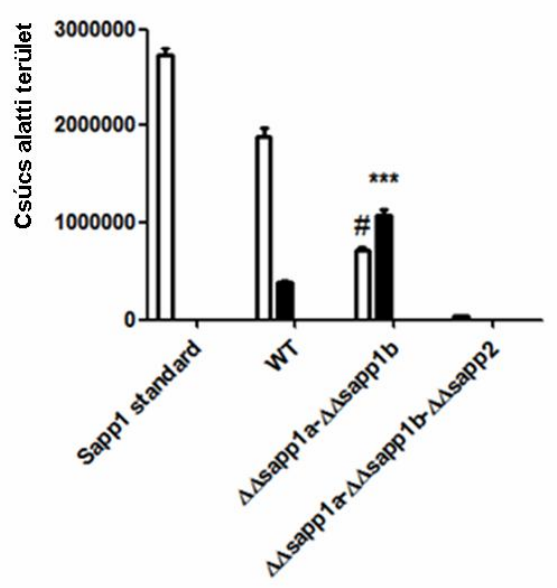

19. ábra

A Sapp1 és Sapp2 fehérjék aktivitásának kvantitatív HPLC analízise. A: a tisztított Sapp1 fehérje aktivitásának kimutatása. B: C. parapsilosis vad típusú törzs felülúszójának Sapp1 és Sapp2 enzimaktivitása. C: a $\Delta / \Delta$ sapp 1a$\Delta / \Delta$ sapp 1 törzs Sapp1 és Sapp2 enzimaktivitásának kromatogramja. D: $\Delta / \Delta$ sappla- $/ / \Delta$ sapplb- $\Delta / \Delta$ sapp2 tripla deléciós törzs HPLC analízise. A $\Delta / \Delta$ sapp $1 a-\Delta / \Delta$ sapp $1 b$ törzs esetén a Sapp2 fehérje termelödésében szignifikáns növekedés figyelhetö meg (E) $(* * *: \mathrm{P}=0,0002)$, míg a $\Delta / \Delta$ sappla- $\Delta / \Delta$ sapp 1 b- $\Delta / \Delta$ sapp 2 tripla deléciós törzs esetén sem a Sapp1, sem a Sapp2 fehérje aktivitása nem figyelhető meg. \#: valószínüsíthetően a Sapp2 fehérje izoformája által létrehozott csúcs.

\subsubsection{A vad típusú és a deléciós törzsek szérumérzékenységének vizsgálata}

C. albicans esetén kimutatták, hogy a szekretált aszpartil proteinázok képesek számos, a humán szérumban megtalálható antimikrobiális fehérje bontására, ezáltal elősegítve a 
mikroba terjedését. Ezen mikroorganizmus fő szekretált proteináza, a CaSap2 képes az immunglobulinok, a katepszin D, valamint komplement komponensek bontására (Hube 1998), (Gropp és mtsai. 2009). Ezen adatokból kiindulva munkánk során vizsgáltuk a vad típusú, valamint a deléciós mutáns törzsek szérumban történő növekedését, amely által információt nyerhettünk arra vonatkozóan, hogy a C. parapsilosis Sapp fehérjéi rendelkeznek-e hasonló tulajdonságokkal. A szérumérzékenység vizsgálathoz a vad típusú és mutáns törzseket $3 * 104 / \mathrm{ml}$ koncentrációban, $20 \%$ intakt, illetve $20 \%$ hővel inaktivált szérumot tartalmazó PBS oldatban $30{ }^{\circ} \mathrm{C}$-on 200 rpm-en rázattuk. 0, 8, 12, 24 és 48 óra elteltével YPD csészére

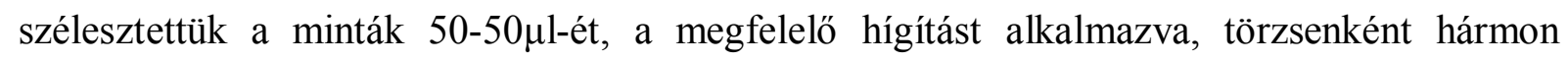
párhuzamos alkalmazásával, majd CFU meghatározást végeztünk. Míg a hővel inaktivált, 20\% humán szérumot tartalmazó kultúrák esetén minden törzs hasonló mértékü növekedésre volt képes, addig a $20 \%$ intakt humán szérumot tartalmazó médium esetén a $\Delta / \Delta$ sappla$\Delta / \Delta$ sapp $1 b$ dupla deléciós mutáns törzs növekedése mind 24 óra, mind 48 óra inkubáció után szignifikáns csökkenést mutatott a vad típusú törzshöz képest. A $\Delta / \Delta$ sappla és $\Delta / \Delta$ sapplb törzsek és a vad típusú törzs növekedési rátája közt nem mutatkozott eltérés (20. ábra). A dupla deléciós mutáns törzs csökkent növekedési rátája arra enged következtetni, hogy a Sapp1 fehérjének -hasonlóan a $C$. albicans Sap2 fehérjéhez- szerepe van a szérumban található komplement komponensek és immunfehérjék bontásában.
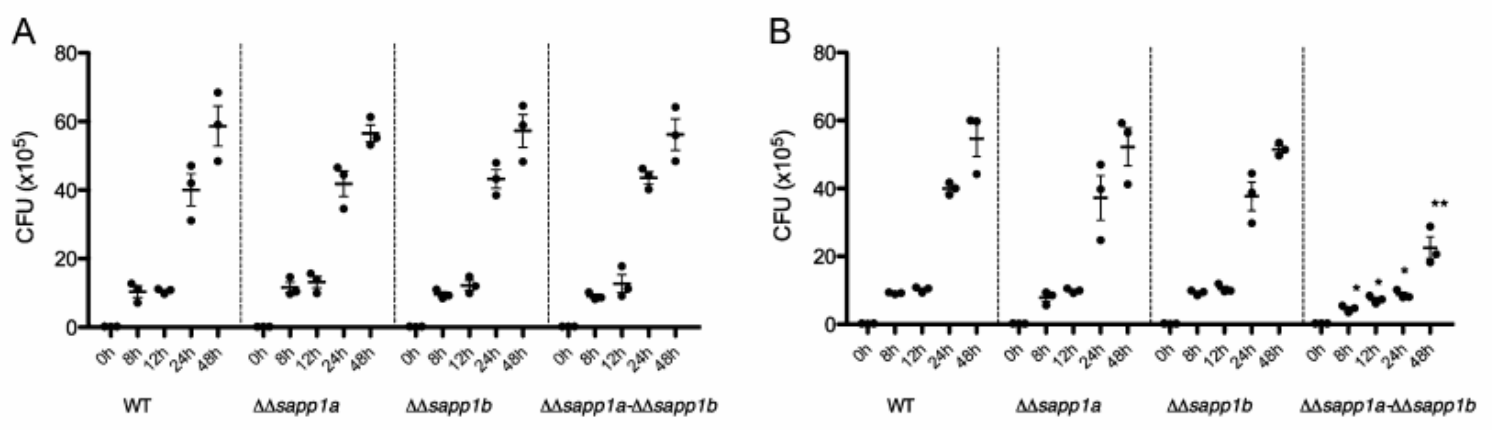

20. ábra

A vad típusú és deléciós mutáns törzsek szérumérzékenységének vizsgálata. A hővel inaktivált (A) 20\% humán szérumot tartalmazó médiumban nem volt a törzsek növekedésében kimutatható különbség, míg a 20\% intakt humán szérumot (B) tartalmazó közegben a $\Delta / \Delta$ sappla- $\Delta / \Delta$ sapplb törzs növekedése szignifikáns csökkenést mutatott $(*: \mathrm{P}<0,05 ; * *: \mathrm{P}<0,005)$.

Hogy kiderítsük, hogy a Sapp aktivitás teljes elvesztése jár-e további szérumérzékenység

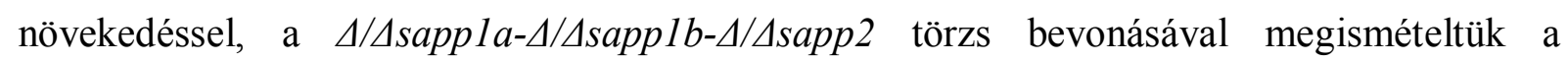
szérumérzékenység vizsgálatát (21. ábra). 
A

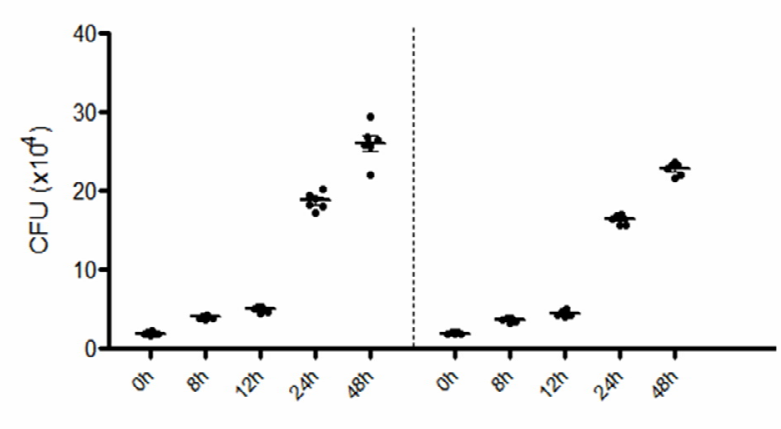

WT

$\Delta / \Delta$ sapp1a- $\Delta / \Delta$ sapp1b- $\Delta / \Delta$ sapp2

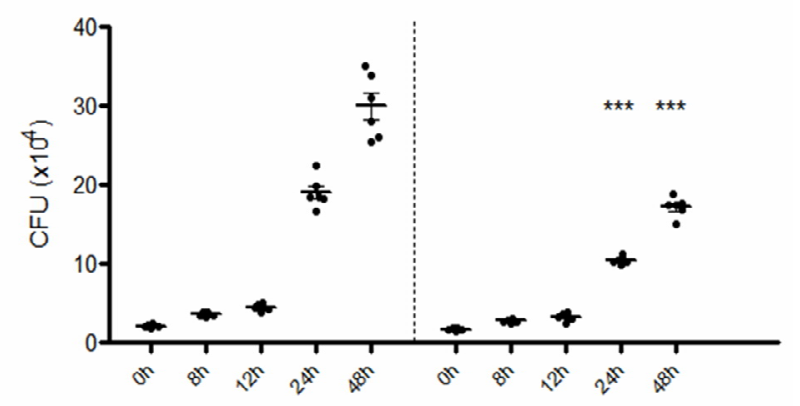

WT

$\Delta / \Delta$ sapp1a- $\Delta / \Delta$ sapp $1 b-\Delta / \Delta$ sapp2

21. ábra

A vad típusú és $\Delta / \Delta$ sappla- $\Delta / \Delta \operatorname{sapp} 1 b-\Delta / \Delta \operatorname{sapp} 2$ deléciós törzs höinaktivált humán szérumban (A) és intakt humán szérumban (B) mért növekedése. A $\Delta / \Delta$ sapp 1 a- $\Delta / \Delta$ sapp $1 b-\Delta / \Delta$ sapp 2 törzs növekedése a vad típusú törzshöz képest mind 24 óra, mind 48 óra után szignifikáns csökkenést mutatott (***: $\mathrm{P}<0,0001$ ).

A hővel inaktivált, 20\% humán szérumban tenyésztett minták esetén egyik időpontban sem figyeltünk meg eltérést a sejtek növekedésében a vad típust és a deléciós mutáns törzset összehasonlítva. Az intakt humán szérumban tenyésztett minták esetén, míg a vad típusú törzs növekedése a hővel inaktivált mintákéhoz volt hasonló, addig a vad típushoz képest a Sapp negatív deléciós mutáns törzs növekedése 24 és 48 órás inkubációt követően jelentős csökkenést mutatott. Előző munkánkban, 48 órás inkubációt követően, intakt humán szérumból származó minták esetén a $\Delta / \Delta$ sappla- $\Delta / \Delta$ sapp $1 b$ mutáns törzs vizsgálata során szintén hasonló növekedés gátlást tapasztaltunk (20. ábra). A C. parapsilosis fő szekretált aszpartil proteináza a Sapp1, amely, ezen eredmény alapján a szérumban lévő proteinek, valamint komplement komponensek fertőzés során történő bontásáért felelős, ezáltal segítve elő a mikroba gazdaszervezetben történő terjedését. Továbbá megállapítottuk, hogy a megmaradó proteináz aktivitás elvesztése nem növeli a mutáns sejtek szérum érzékenységét, megerősítve a $C$. albicans esetében már bizonyított feltételezést az egyes proteináz enzimek egymástól eltérő funkciójáról.

\subsubsection{A vad típusú és mutáns törzsek fagocitózisának vizsgálata}

A veleszületett immunitás fő effektor sejtjei a monocitákból differenciálódott makrofágok, melyek elsőként, a fertőzés korai szakaszában képesek kapcsolatba lépni és fagocitózis útján semlegesíteni a behatoló mikrobákat (Netea és mtsai. 2008). Munkánk során vizsgáltuk a vad típusú, valamint deléciós mutáns törzsek primer humán makrofágok (PBMC-DM sejtek) általi fagocitózisának hatékonyságát. A vad típusú és mutáns törzsek primer humán makrofágok általi fagocitózisának vizsgálatához áramlási citometriás mérést (FACS) alkalmaztunk. A vad típusú és $\Delta / \Delta$ sappla, $\Delta / \Delta$ sapplb és $\Delta / \Delta$ sappla- $\Delta / \Delta$ sapplb törzseket fluoreszcein- 
izotiocianáttal (FITC) festettük, míg a makrofág sejtek jelölése CD14-fikoeritrin (PE) antitesttel történt. Kontrollként jelöletlen, illetve CD14-fikoeritrin (PE) antitesttel jelölt primer humán makrofág sejteket alkalmaztunk. A mérés során a vad típusú törzshöz képest a

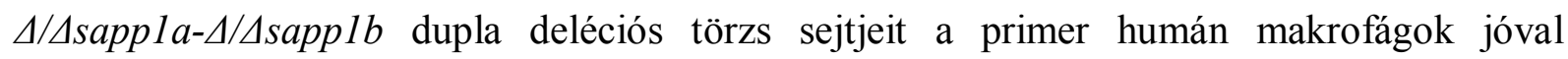
hatékonyabban fagocitálták ( wt: 35,8\%, $\Delta / \Delta$ sappla- $\Delta / \Delta$ sapplb törzs: 52,9\%) (22. ábra).
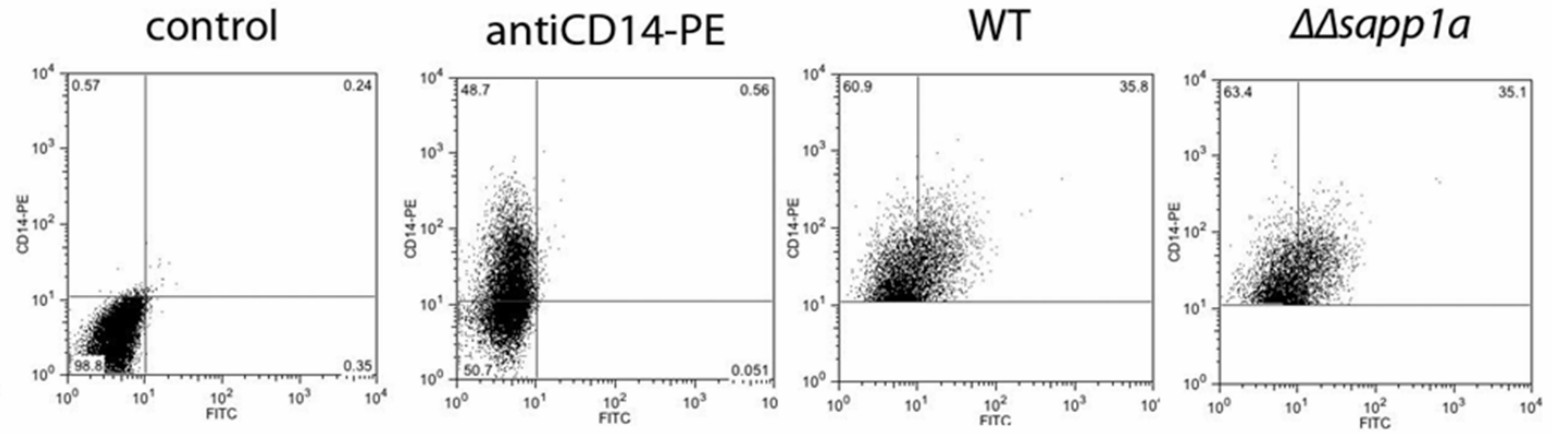

\section{$\triangle$ sapp 16}

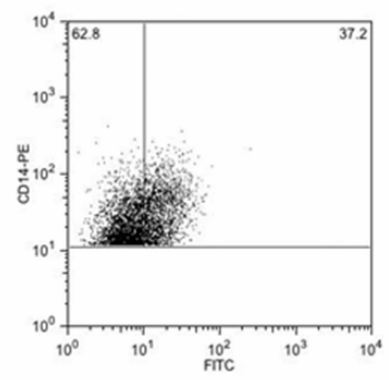

$\Delta$ sapp1a- $\Delta$ sapp $1 b$

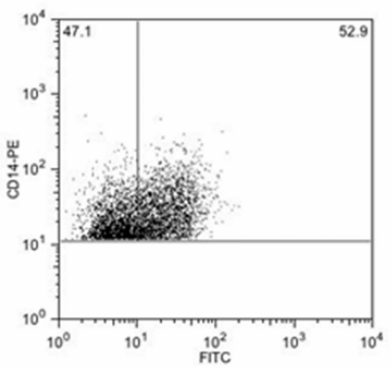

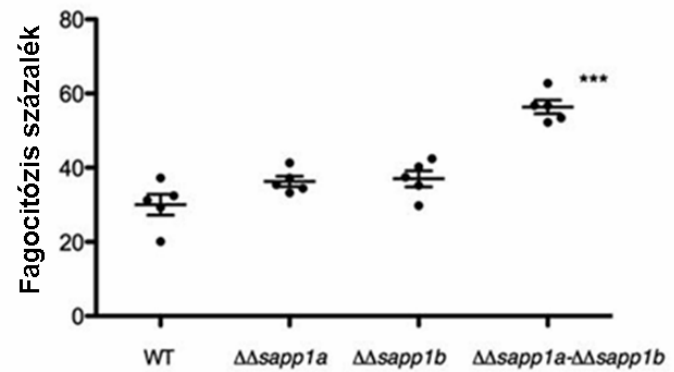

22. ábra

A vad típusú és deléciós törzsek fagocitózisának áramlási citomertiás vizsgálata. A $\Delta / \Delta$ sappla- $\Delta / \Delta$ sapplb törzs fagocitózisának százaléka szignifikánsan nagyobbnak bizonyult, mint a vad típusú törzsé (***: $\mathrm{P}<0,0001)$.

A fertőzés elött a vad típusú és $\Delta / \Delta$ sappla- $\Delta / \Delta \operatorname{sapp} 1 b-\Delta / \Delta \operatorname{sapp} 2$ mutáns törzset Alexa Fluor 647 (Life Technologies) fluoreszcens festékkel festettük. A fertőzést ebben az esetben is ötszörös mennyiségủ élesztő sejttel végeztük el. Több donorból származó fagocitózis adatokat összesítve a vad típushoz képest a proteáz negatív törzzsel végzett koinkubáció esetén szignifikánsan nagyobb mértékű fagocitózis volt megfigyelhető (wt: 42\%, $\Delta / \Delta$ sappla$\Delta / \Delta$ sapp 1b- $\Delta / \Delta$ sapp2: 60\%) (23. ábra). 

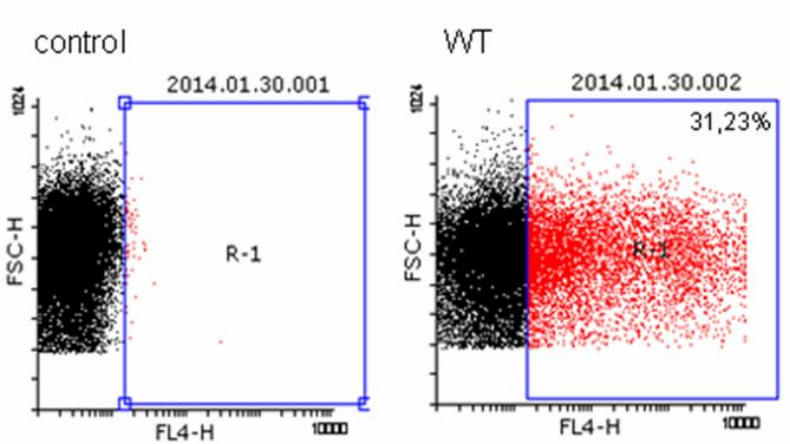

$\Delta / \Delta$ sapp $1 a-\Delta / \Delta$ sapp $1 b$
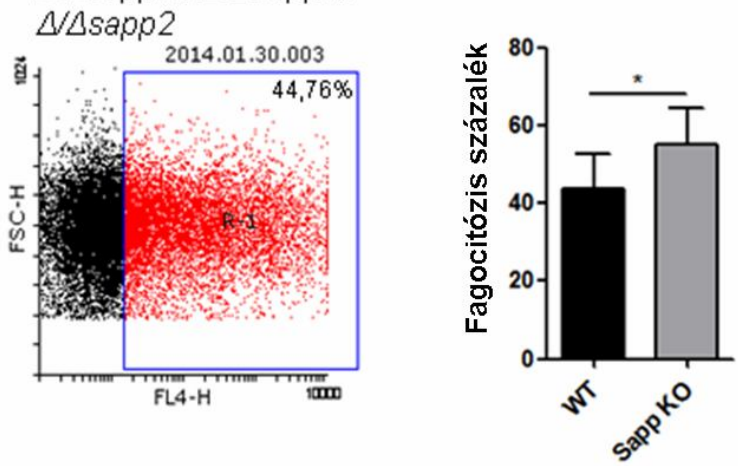

23. ábra

A vad típusú és $\Delta / \Delta$ sappla- $\Delta / \Delta$ sapp $1 b-\Delta / \Delta$ sapp 2 törzsek primer humán makrofágok (PBMC-DM) általi fagocitózisa. A $\Delta / \Delta$ sapp $1 a-\Delta / \Delta \operatorname{sapp} 1$ b- $\Delta / \Delta$ sapp 2 törzzsel való fertőzésből származó minta esetén szignifikánsan emelkedett a fagocitózis mértéke $(*: \mathrm{P}<0,05)$.

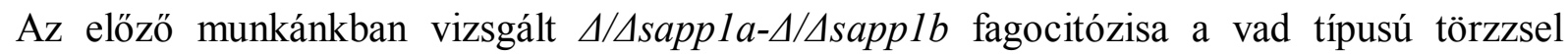
összevetve mintegy 40\%-os emelkedést mutatott. A Sapp negatív törzs fagocitózisa szintén 40\%-al volt magasabb a vad típusú sejtek bekebelezési hatékonyságánál (wt: 42\%,

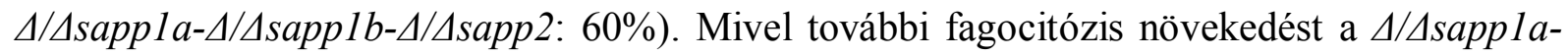
$\Delta / \Delta$ sapplb- $\Delta / \Delta$ sapp 2 törzs esetén nem tapasztaltunk, ez szintén arra enged következtetni, hogy $C$. parapsilosis esetén a fagocitózis gátlásában elsősorban a Sapp1 játszik szerepet.

Annak érdekében, hogy a vad típusú és a $S A P P 1$ deléciós mutáns törzsek esetén a fagocitózis folyamatát részleteiben tanulmányozhassuk, fluoreszcens mikroszkópos technikát is alkalmaztunk, melynek során a fagoszómák és lizoszómák kolokalizációját vizsgáltuk.

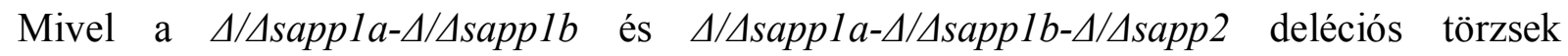
gazdasejtek általi fagocitózisának mértékében különbséget nem találtunk és a fagocitózis gátlásában a Sapp1 játszik szerepet, így a fago-lizoszóma kolokalizációs vizsgálatokba a vad típusú és a $\Delta / \Delta$ sappla- $\Delta / \Delta$ sapplb törzseket vontuk be. A vad típusú és $\Delta / \Delta$ sappla, $\Delta / \Delta$ sapplb és $\Delta / \Delta$ sappla- $\Delta / \Delta$ sapplb törzseket Calcofluor White (Sigma) festettük. A koinkubációs idő letelte után a humán makrofág sejteket Lysotracker Red (Invitrogen) festékkel festettük. A dupla deléciós mutáns törzs esetén szignifikánsan nagyobb mértékü fago-lizoszóma fúzió volt megfigyelhető a vad típusú törzzsel összevetve ( $\Delta / \Delta$ sappla- $\Delta / \Delta \operatorname{sapplb} 71 \%$, wt 30\%, $\mathrm{P}<0,0001)$ (24. ábra). A $\Delta / \Delta$ sappla és $\Delta / \Delta$ sapplb törzsek esetén a vad típusú törzzsel összevetve nem mutatkozott különbség a fago-lizoszóma fúziót vizsgálva. Ezen eredmények azt támasztják alá, hogy a Sapp1 fehérjének fontos szerepe van mind a fagocitózis folyamatának gátlásában, mind a már bekebelezett gomba intracelluláris túlélése során. 

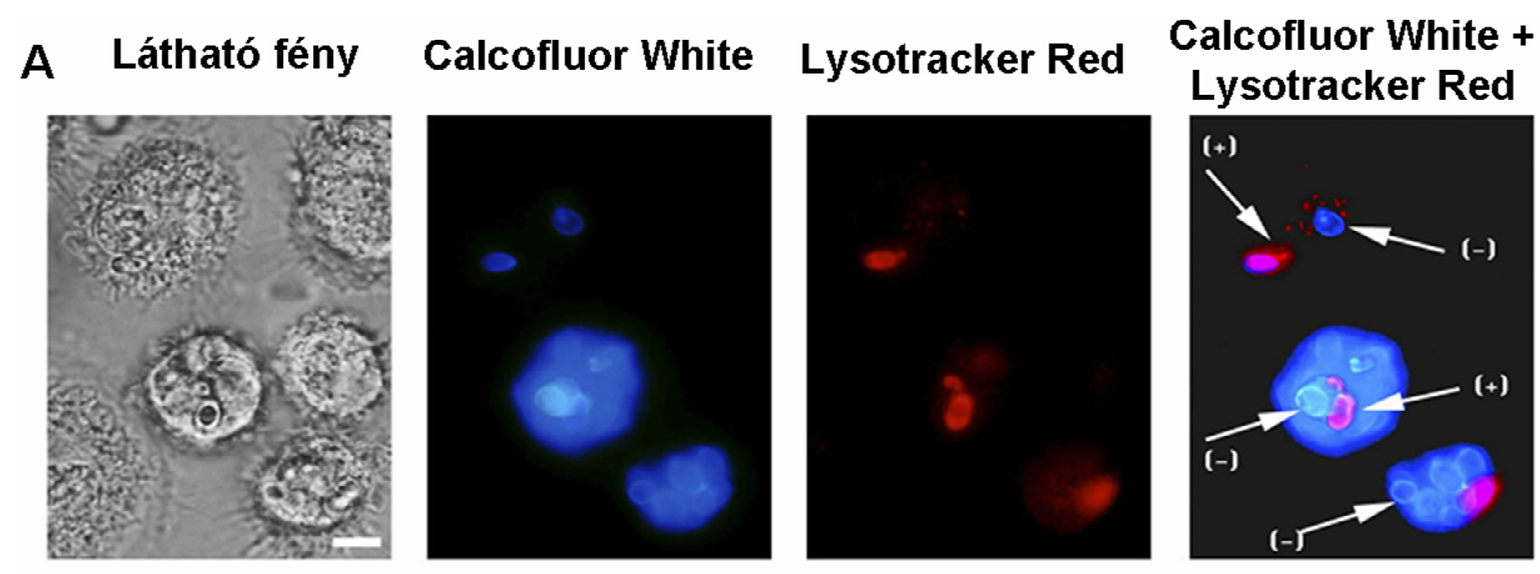

\section{B}
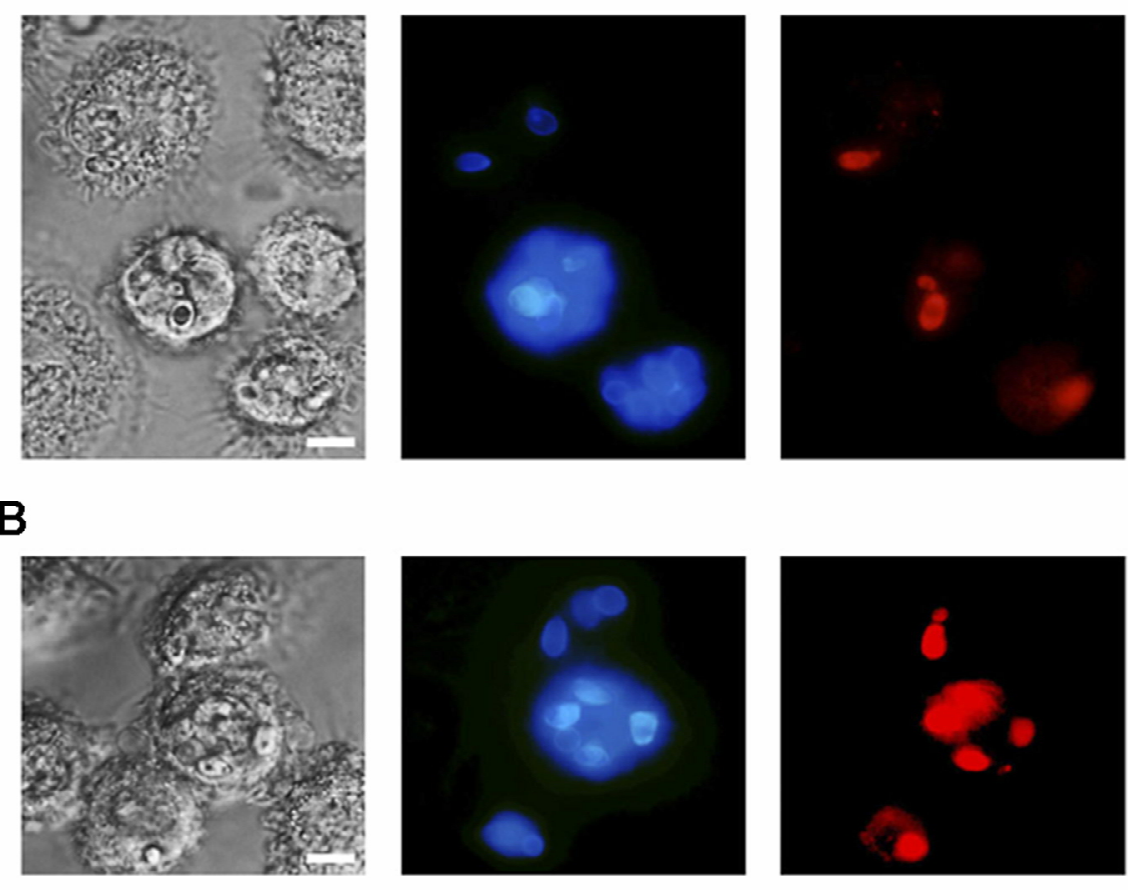

\section{4. ábra}

Fago-lizoszóma fúzió vizsgálata vad típusú (A) és $\Delta / \Delta$ sappla- $\Delta / \Delta$ sapplb (B) törzs esetén. Az élesztő sejtek Calcofluor White-tal, míg a primer humán makrofágok Lysotracker Red-del festettek. A $\Delta / \Delta$ sappla- $\Delta / \Delta$ sapp $1 b$ törzs esetén nagyobb mértékű fago-lizoszóma fúzió volt megfigyelhető.

\subsubsection{A periferiális mononukleáris sejtek (PBMC) és abból differenciáltatott} makrofágok (PBMC-DM) gombaölési hatékonysága

A makrofágok általi felismerést és fagocitózist követően, intracellulárisan a primer fagoszóma és lizoszóma fúzióját követően a makrofág sejteken belül megtörténhet a patogén eliminációja. Ezen ölési folyamat tanulmányozásához a SAPP1 deléciós mutáns törzsek esetén PBMC és PBMC-DM sejtek felhasználásával mértük a vad típusú és mutáns törzsek gazdasejtek általi gombaölési hatékonyságát. A vad típusú és mutáns törzsekkel való koinkubáció után a gazda sejtek elroncsolását követően CFU meghatározást végeztünk. Mind a PBMC, mind a PBMCDM sejtek esetén jelentős mértékü gombaölési hatékonyság volt megfigyelhető. PBMC sejtek esetén szignifikánsan hatékonyabb volt a $\Delta / \Delta$ sappla- $\Delta / \Delta$ sapp $1 b$ dupla deléciós mutáns törzs eliminációja a vad típussal összehasonlítva (59,69\% vs 31,6\%, P<0,0001) (25/A ábra). PBMC-DM sejtek esetén a vad típushoz képest a $\Delta / \Delta$ sappla és $\Delta / \Delta$ sapplb törzsek gazdasejt általi eliminációja is szignifikánsan magasabbnak bizonyult (átlagosan 63,5\% -os ölési hatékonyság a deléciós mutánsok esetén és 44,9\% -os ölési hatékonyság a vad típusú törzs esetén, $\mathrm{P}<0,001)(25 / \mathrm{B}$ ábra). 
A

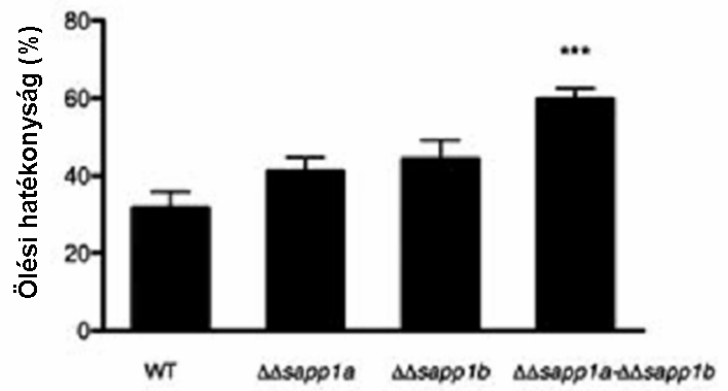

B

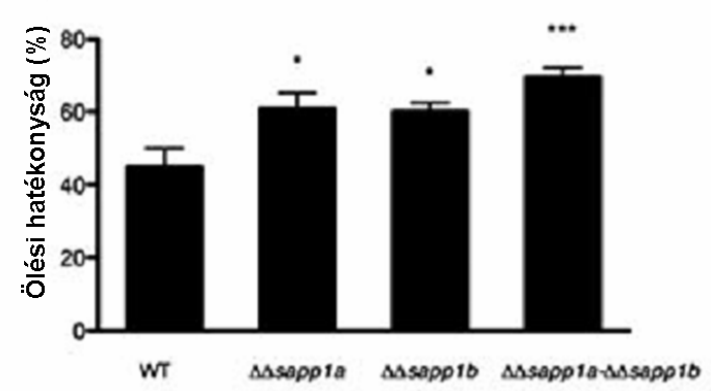

25. ábra

Periferiális mononukleáris sejtek (A) és azokból differenciáltatott makrofágok (B) gombaölési hatékonyságának vizsgálata vad típusú, $\Delta / \Delta$ sappla, $\Delta / \Delta$ sapplb és $\Delta / \Delta$ sappla- $\Delta / \Delta$ sapplb deléciós törzsek esetén. A PBMC sejtek szignifikánsan nagyobb mértékben voltak képesek eliminálni a dupla deléciós mutáns törzset a vad típussal összehasonlítva (***: $\mathrm{P}<0,0001)$, míg a PBMC-DM sejtek esetén már a $\Delta / \Delta$ sappla és $\Delta / \Delta$ sapp $1 b$ törzsek esetén is szignifikánsan nőtt a gazda sejtek általi gomba eliminációs képesség (*:P<0,05).

Annak kiderítése érdekében, hogy proteináz termelés képességének elvesztése okoz-e további

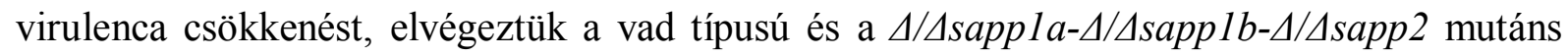
törzsek PBMC-DM sejtek általi gombaölési hatékonyságának vizsgálatát. Mind a vad típusú, mind a Sapp negatív mutáns törzs esetén jelentős mértékü gombaölési hatékonyság volt megfigyelhető, ám a $\Delta / \Delta \operatorname{sapp} 1 a-\Delta / \Delta \operatorname{sapp} 1$ - $-\Delta / \Delta \operatorname{sapp} 2$ mutáns törzs esetén a gazdasejtek általi gombaölési hatékonyság szignifikáns emelkedést mutatott (wt: 24\%, $\Delta / \Delta$ sappla- $\Delta / \Delta$ sapplb-

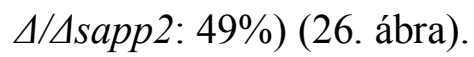

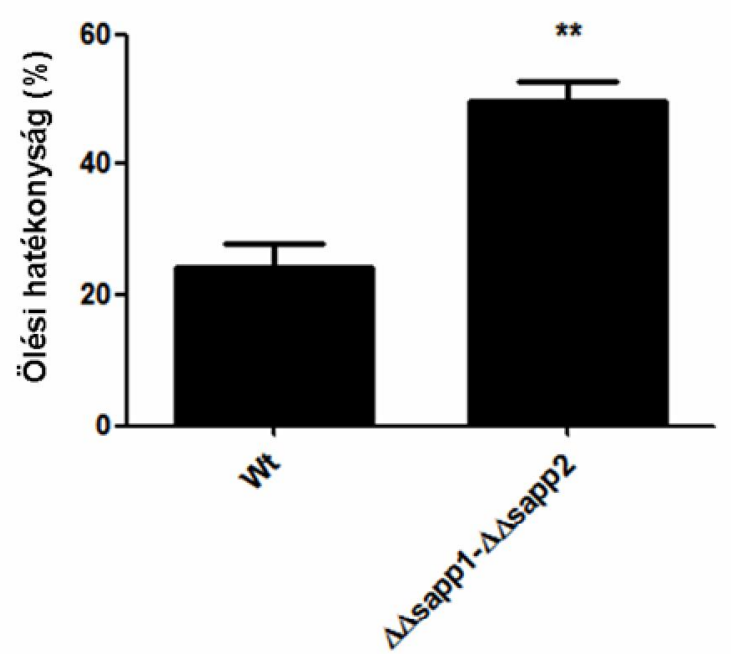

26. ábra

A vad típusú és $\Delta / \Delta$ sappla- $\Delta / \Delta$ sapp $1 b-\Delta / \Delta$ sapp 2 törzsek primer humán makrofágok általi eliminációjának mértéke. A deléciós mutáns törzs eliminációjának mértéke szignifikánsan emelkedett(**: $\mathrm{P}<0,01)$.

Ebben az esetben a $\Delta / \Delta \operatorname{sapp} 1 a-\Delta / \Delta \operatorname{sapp} 1 b-\Delta / \Delta \operatorname{sapp} 2$ mutáns törzzsel szembeni gazdasejtek ölési hatékonysága mintegy kétszerese volt a vad típusú törzzsel összevetve. Előző munkánk 
során a PBMC-DM sejtek vad típussal szembeni ölés hatékonysága 44,9\% volt, míg a $\Delta / \Delta$ sappla- $\Delta / \Delta$ sapplb törzzsel szembeni ölési hatékonyság 63,5\%-nak adódott, amely mintegy 1,4-szeres hatékonyság növekedésnek felel meg (25/B ábra). Ezen eredmény szerint a Sapp negatív mutáns törzzsel szembeni gombaölési hatékonyság további növekedést

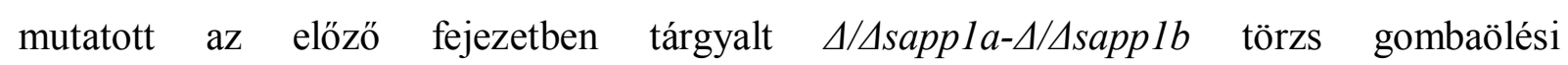
hatékonyságához képest, amely felveti a Sapp1-től eltérő szekretált proteinázok esetleges sejten belüli túlélésben betöltött szerepének lehetőségét, ennek részletesebb vizsgálata azonban további kísérleteket kíván.

\subsubsection{A gazda sejtek károsodásának mérése}

Számos patogén gombafaj esetén kimutatták, hogy különböző stratégiák állnak rendelkezésre a mikroba számára, amelyekkel sikeresen képesek túlélni a makrofágok általi bekebelezést (Seider és mtsai. 2010). Ezen túlélési stratégiák sok esetben a gazdasejt pusztulásához vezetnek. Fluoreszcens mikroszkópos vizsgálataink kimutatták, hogy több fago-lizoszóma képződött a $\Delta / \Delta$ sapp $1 a-\Delta / \Delta$ sapplb deléciós mutáns törzzsel fertőzött minta esetén, amely arra enged következtetni, hogy a Sapp1 fehérjének szerepe van a mikroba sejten belüli túlélésében. Mindezeket alapul véve megvizsgáltuk a vad típusú és mutáns törzsek gazdasejt károsító képességét. Ahhoz, hogy a vad típusú és deléciós mutáns törzsek gazdasejt károsodásának mértékét mérjük, primer humán PBMC-DM sejteket fertőztünk vad típusú és deléciós mutáns törzsekkel. 24 és 48 óra koinkubáció elteltével a felülúszókból mért laktát-dehidrogenáz (LDH) aktivitásának mértékéből következtettünk a gazdasejtek károsodásának mértékére. 24 órás koinkubáció után nem volt megfigyelhető változás a vad típusú, illetve a deléciós mutáns törzsekkel fertőzött gazdasejtek károsodásának mértékében. 48 óra koinkubációs időtartam után a vad típussal fertőzött gazdasejtek esetén volt megfigyelhető a legnagyobb mértékü gazdasejt pusztulás. A $\Delta / \Delta$ sappla és $\Delta / \Delta$ sapp $1 b$ törzsek esetén a károsodás kisebb mértékü volt, ám nem szignifikáns mértékben. A $\Delta / \Delta$ sappla- $\Delta / \Delta$ sapp 1 d dupla deléciós mutáns törzzsel való fertőzés esetén a gazdasejtek károsodása csökkent mértékünek bizonyult a vad típusú törzshöz képest (27. ábra). 


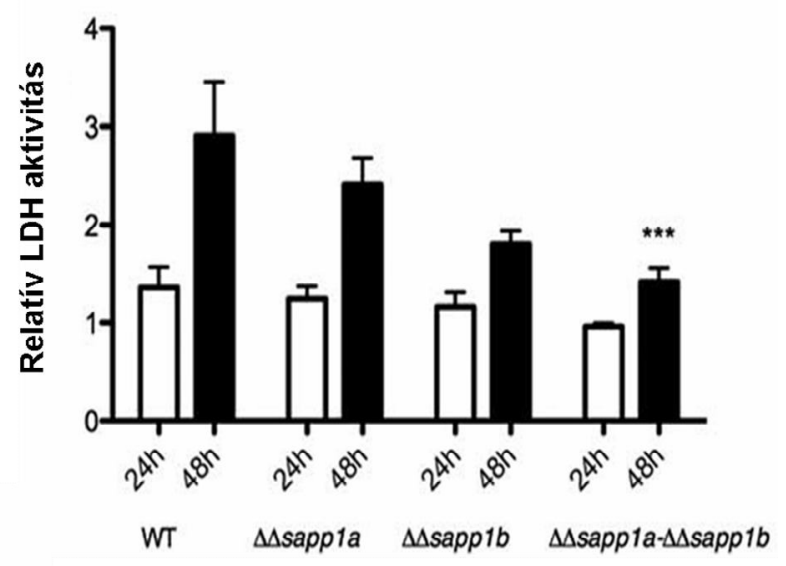

27. ábra

A vad típusú és $\Delta / \Delta$ sappla, $\Delta / \Delta$ sapplb és $\Delta / \Delta$ sappla- $\Delta / \Delta$ sapplb törzsek gazdasejt károsító képessége 24 és 48 óra eltelte után. A $\Delta / \Delta$ sappla- $\Delta / \Delta$ sapp $1 b$ törzs gazdasejt károsító képessége 48 óra elteltével a vad típushoz képest szignifikánsan kisebbnek bizonyult $(* * *: \mathrm{P}<0,0001)$.

Munkánk további részében vizsgáltuk a vad típusú, valamint a Sapp negatív törzs gazdasejt károsító képességét is, szintén PBMC-DM sejtek felhasználásával. A vizsgálat során 24 óra koinkubáció elteltével a vad típusú és a $\Delta / \Delta \operatorname{sapp} 1 a-\Delta / \Delta \operatorname{sapp} 1 b-\Delta / \Delta \operatorname{sapp} 2$ deléciós mutáns törzs által okozott gazdasejt károsodásának a mértékében nem mutatkozott különbség. 48 óra koinkubáció esetén, hasonlóan az előzőekben leírtakhoz, a vad típusú törzs szignifikánsan nagyobb mértékben károsította a gazdasejteket, mint a deléciós mutáns törzs (28. ábra).

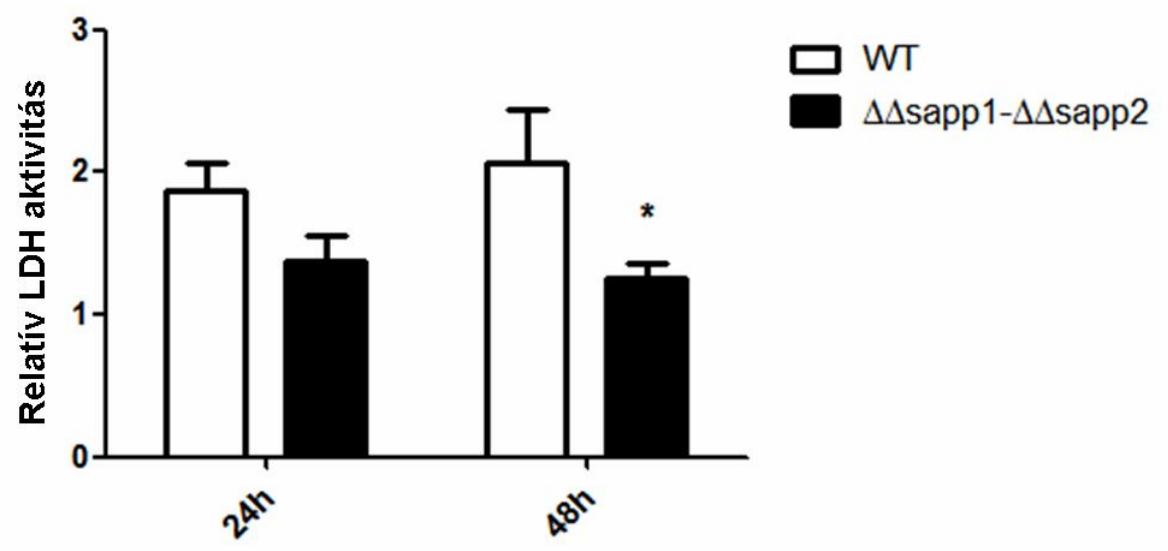

28. ábra

A vad típusú és $\Delta / \Delta$ sappla- $\Delta / \Delta$ sapp $1 b-\Delta / \Delta$ sapp 2 deléciós mutáns törzsek gazdasejt károsító képessége. 48 óra koinkubáció után a deléciós mutáns törzs által okozott károsodás mértéke szignifikánsan kisebbnek bizonyult a vad típussal összevetve (*: $\mathrm{P}<0,05)$. 
Az adatokat összevetve 24 óra koinkubációt követően sem a vad típus, sem a $\Delta / \Delta$ sappla-

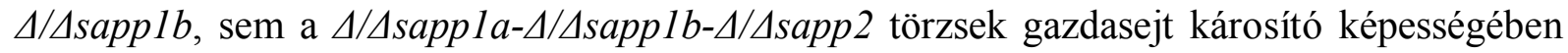
nem mutatkozott különbség. 48 óra koinkubációt követően a vad típushoz képest mind a

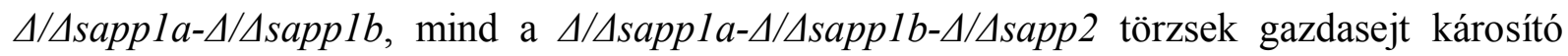
képessége szignifikánsan kisebb volt, ám a két deléciós törzset összevetve a gazdasejtek károsodásában különbség nem mutatkozott. Ez az eredmény azt támasztja alá, hogy a $C$. parapsilosis szekretált aszpartil proteinázai közül a Sapp1 az, amely gazda sejtjeinek károsításában a legjelentősebb szereppel bír.

\subsubsection{Humán PBMC-DM sejtek vad típusú és Sapp negatív törzsekkel való}

\section{fertőzésre adott immunválasza}

C. albicans-ban egy tanulmány vizsgálta különböző rekombináns Sap fehérjék által kiváltott proinflammatorikus citokinek termelődésének változását primer monocita sejteken (Pietrella és mtsai. 2010). Ezen tanulmányban kimutatták, hogy a Sap1, Sap2 és Sap6 fehérjék szignifikánsan megnövelték a monociták által termelt IL-1 $\beta$, TNF- $\alpha$ és IL-6 mennyiségét. Ezen kívül a $C$. albicans Sap3 fehérjéje szignifikánsan növelte a primer monociták által termelt IL-1 $\beta$ és TNF- $\alpha$ mennyiségét.

Annak kiderítésére, hogy C. parapsilosis esetén a szekretált aszpartil proteinázoknak van-e valamilyen hasonló immunmoduláló szerepe, humán PBMC-DM sejtek vad típusú és Sapp negatív mutáns törzsek általi fertőzése során vizsgáltuk a gazdasejtek által termelt proinflammatorikus citokinek szintjét. A humán gazdasejteket ötszörös mennyiségü élesztő sejttel fertőztük, majd 24 órás koinfekció után enzimkötött immunoszorbens assay (ELISA) módszerrel vizsgáltuk a gyulladásos citokinek termelődésének mennyiségét. A vizsgálat során a proinflammatorikus citokinek: IL-1 $\beta$, IL-6 és TNF $\alpha$ mennyiségi vizsgálatát végeztük el (29. ábra).
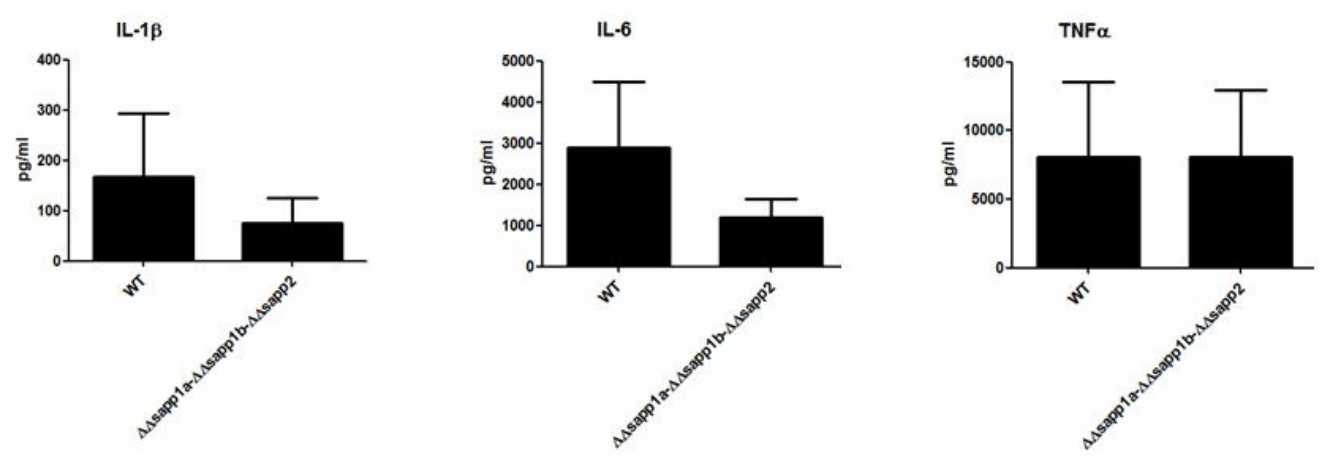

29. ábra

Humán PBMC-DM sejtek vad típusú és deléciós mutáns törzzsel való fertőzése során termelt proinflammatorikus citokinjeinek mennyisége. 
Eredményeink azt mutatják, hogy az IL-1 $\beta$, valamint az IL-6 termelődése, bár a vad típusú törzzsel összevetve a deléciós mutáns törzs esetén csökkenést mutatott, ám a csökkenés mértéke nem volt szignifikáns mértékü. A TNFa termelődése esetén a vad típussal, illetve a deléciós mutánssal fertőzött minták esetén különbséget nem tapasztaltunk. Ezen előzetes eredmények azt mutatják, hogy PBMC-DM sejtek esetén a Sapp fehérjéknek a gyulladásos válasz kialakulásának kezdeti szakaszában lehet immunmoduláló szerepe, ám ez a hatás elhanyagolható. A C. parapsilosis szekretált aszpartil proteinázainak immunmoduláló szerepének teljes tisztázása érdekében a PBMC-DM sejtek mellett más modellrendszerek (pl. epitéliális sejtek, sejtvonalak) jövőbeli alkalmazása, valamint az anti-inflammatorikus citokinek vizsgálata szintén szükséges.

\subsubsection{Nagy viaszmoly (Galleria mellonella) lárvák túlélésének in vivo vizsgálata}

A nagy viaszmoly ( $G$. mellonella) lárvák jellemző tulajdonsága, hogy az adaptív immunrendszerre jellemző sejtes elemekkel nem, csupán hemocitákkal rendelkeznek, melyek ősi fagocita sejtek, ezáltal az organizmus alkalmas modellrendszert jelentenek a veleszületett immunitás in vivo tanulmányozására. A nagy viaszmoly továbbá egy egyszerü, könnyen kezelhető modellrendszert biztosít, melynek alkalmazásával in vivo túlélési vizsgálatok könnyen kivitelezhetőek, akár nagy számú mikroba törzs alkalmazásával (Jacobsen 2014). Munkánk során G. mellonella lárvák in vivo túlélését vizsgáltuk. A vizsgálat során tíz-tíz egyedet fertőztünk vad típusú és $\Delta / \Delta$ sappla- $\Delta / \Delta$ sapp 1 b- $\Delta / \Delta$ sapp 2 deléciós mutáns törzzsel, kontrollként pedig tíz egyedet PBS pufferrel injektáltunk, majd naponta vizsgáltuk a fertőzött egyedek túlélését (30. ábra).

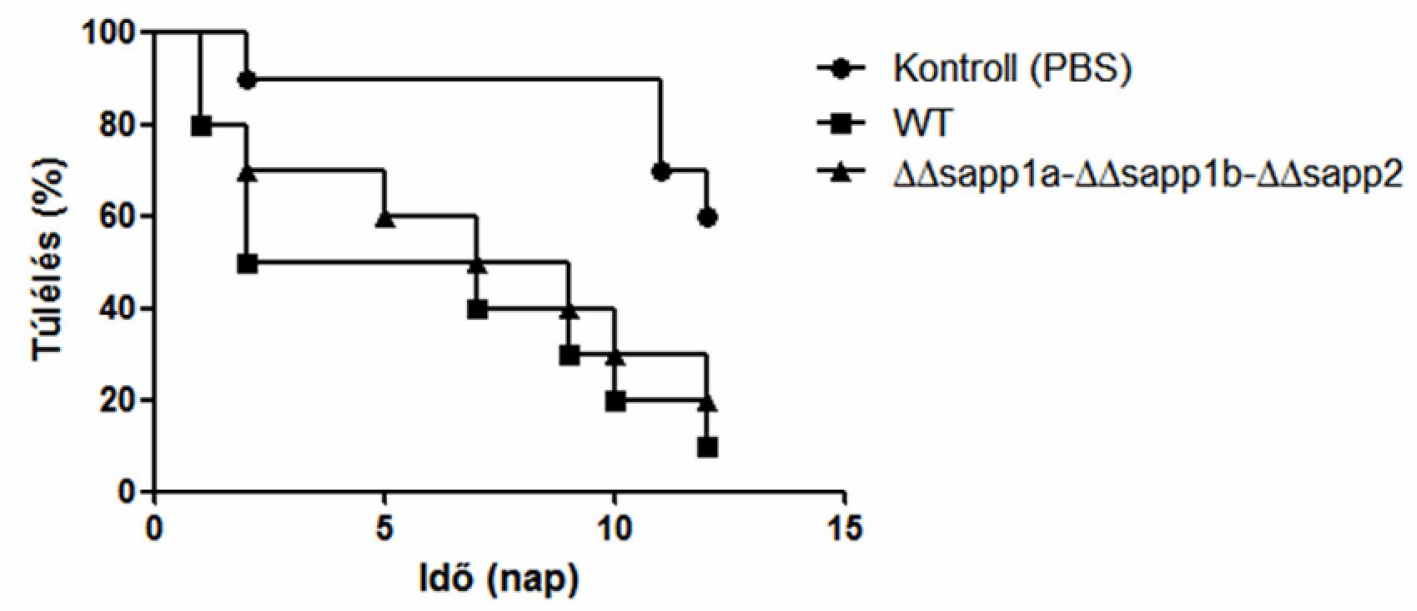

30. ábra

G. mellonella lárvák in vivo túlélésének vizsgálata 
Bár a vad típusú törzzsel és a deléciós mutáns törzzsel fertőzött csoportot összehasonlítva nem kaptunk szignifikáns különbséget a lárvák túlélésében, egyetlen időpontban sem, ám ezen modellszervezet alkalmazása csupán mint előkísérlet volt további in vivo túlélési kísérletekhez. További munkánk során tervezzük más modellrendszerek alkalmazását in vivo túlélési vizsgálatokhoz.

\subsubsection{A $C$. parapsilosis vad típusú, $\Delta / \Delta$ sapp1a- $\Delta / \Delta$ sapp1b és $\Delta / \Delta$ sapp1a-}

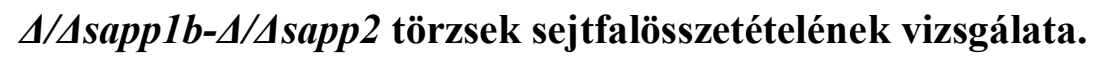

Prof. Leonardo Nimrichter csoportjával együttmüködve, módunk nyílt a vad típusú, a

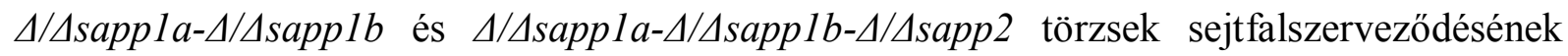
vizsgálatára. Ezen vizsgálatok során fluoreszcens mikroszkópos módszerrel vizsgáltuk a sejtfal összetevők egyes komponenseinek mennyiségét. Mennyiségi adatokra a fluoreszcencia intenzitás mértékéből tudtunk következtetni. A mannoproteinek mennyiségének vizsgálatához ConA festéket, a kitin tartalom méréséhez Calcofluor White festéket, valamint az élesztő osztódása során keletkező szeptumok vizsgálatához WGA fluoreszcens festéket alkalmaztunk (31. ábra).
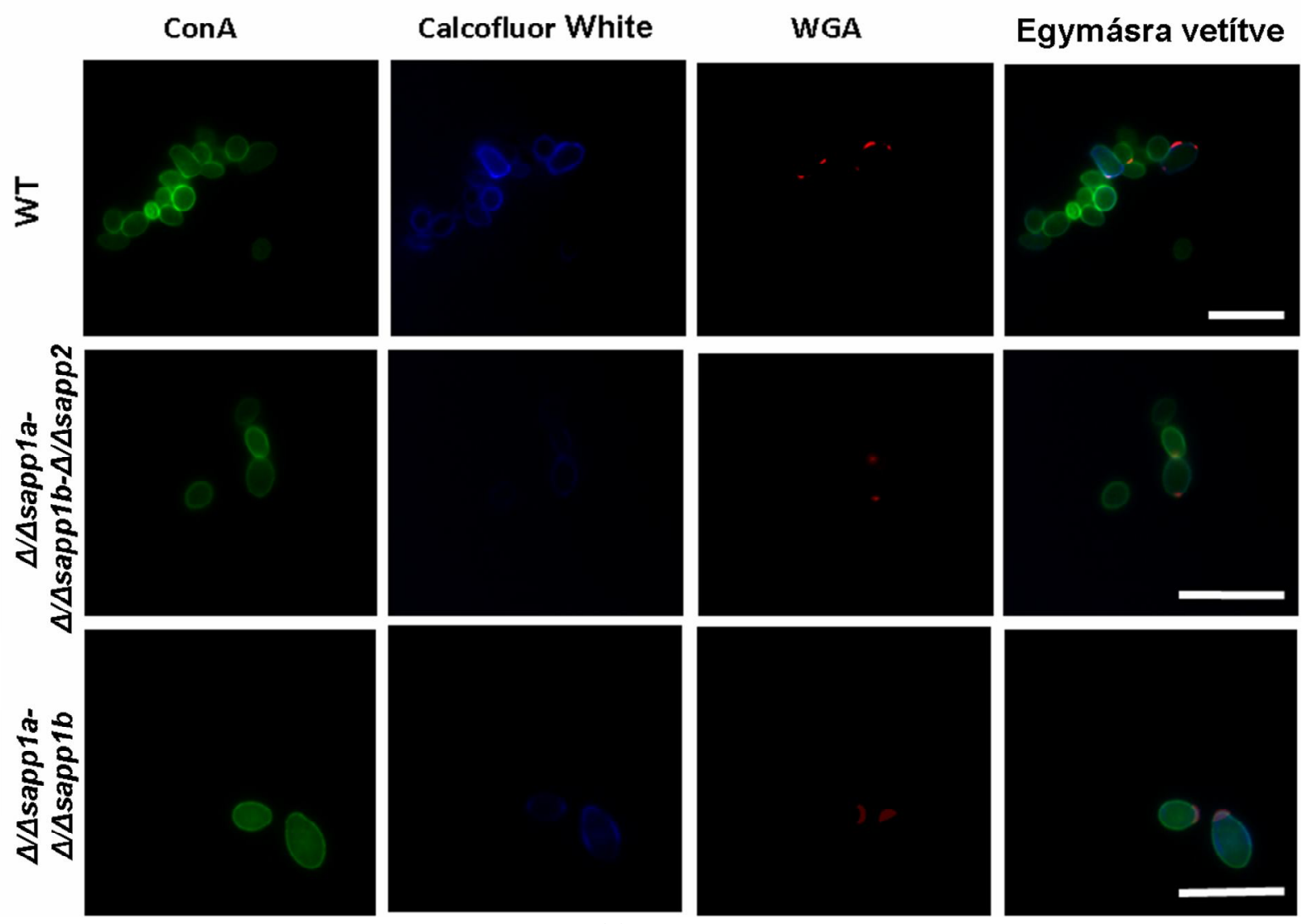

31. ábra

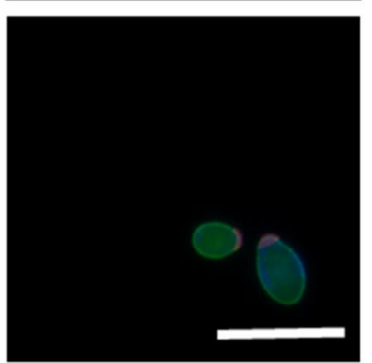

A vad típusú, a $\Delta / \Delta$ sappla- $\Delta / \Delta$ sapplb és $\Delta / \Delta$ sappla- $\Delta / \Delta$ sapp $1 b-\Delta / \Delta$ sapp2 törzsek sejtfalszerveződésének fluoreszcens mikroszkópos vizsgálata. 
Eredményeink azt mutatják, hogy a mannoproteinekre specifikus ConA festék és az osztódás során képződő szeptumokra specifikus WGA festék fluoreszenciájában nem mutatkozott

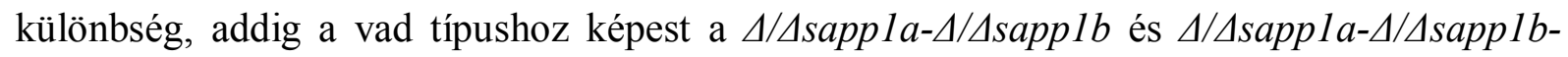
$\Delta / \Delta$ sapp2 törzsek esetén a Calcofluor White intenzitása jelentősen csökkent, amely azt mutatja, hogy a két deléciós törzs sejtfalának kitin tartalma jelentős mértékben lecsökkent. A vad típusú és deléciós mutáns törzsek sejtfalának glükán tartalmának meghatározásához anilinkék festést végeztünk. Érdekes módon a $\Delta / \Delta \operatorname{sapp} 1 a-\Delta / \Delta \operatorname{sapp} 1$ b- $\Delta / \Delta \operatorname{sapp} 2$ törzs esetén a glükán tartalom jelentősen nagyobb volt, mint a vad típusú és $\Delta / \Delta$ sappla- $\Delta / \Delta \operatorname{sapp} 1 b$ törzs esetén, amely jól demonstrálja, hogy a szekretált aszpartil proteinázok jelentős szerepet töltenek be a mikroba sejtfal integritásának fenntartásában (32. ábra).
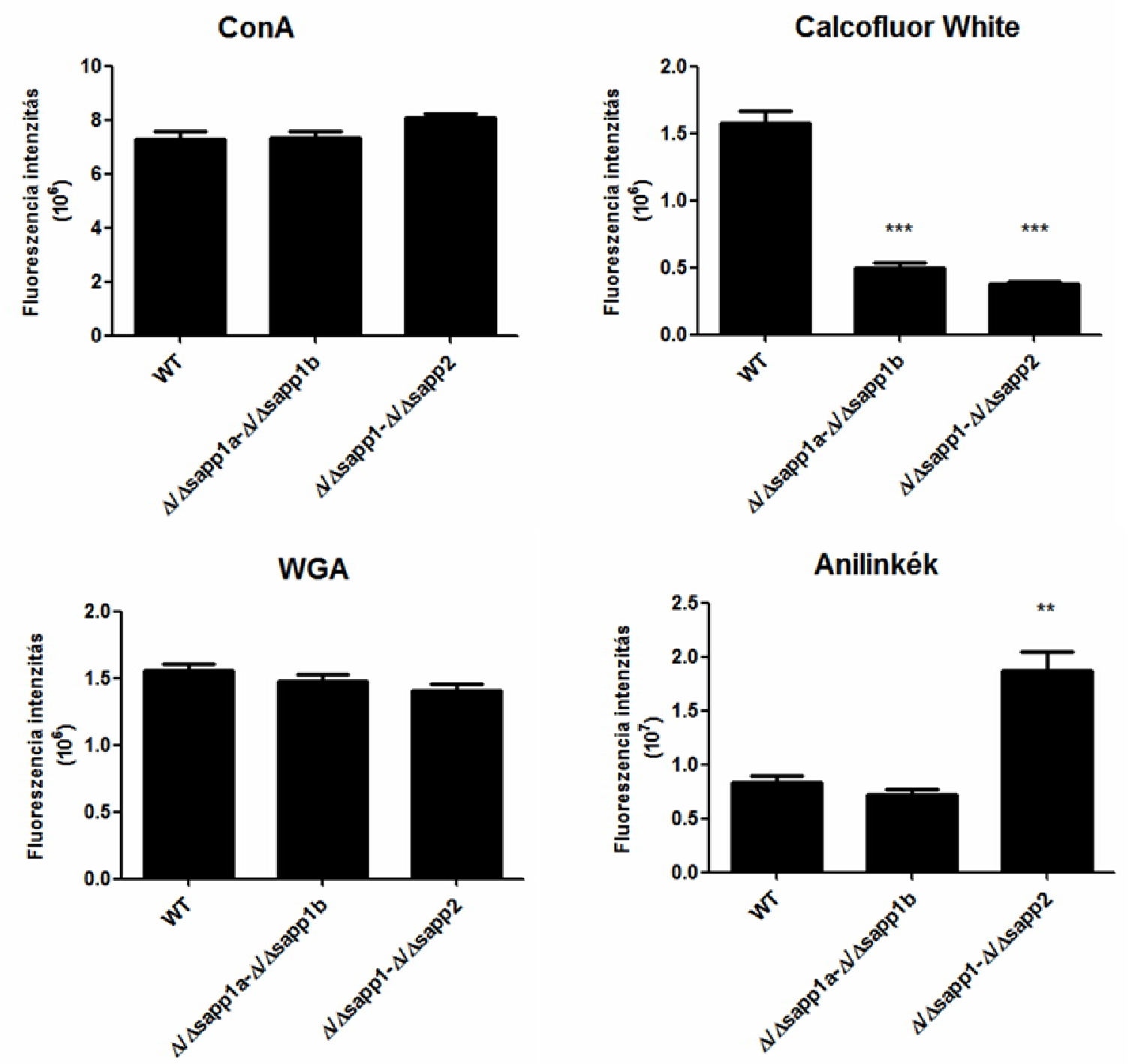

32. ábra

A vad típusú, a $\Delta / \Delta$ sappla- $\Delta / \Delta$ sapplb és $\Delta / \Delta$ sappla- $\Delta / \Delta$ sapp $1 b-\Delta / \Delta$ sapp 2 törzsek sejtfal komponensekre specifikus festékek fluoreszencia intenzitásai $(* *: \mathrm{P}<0,01, * * *$ : $\mathrm{P}<0,001)$. 
Módunk nyílt ezen felül szintén Prof. Leonardo Nimrichter csoportjának köszönhetően scanning elektronmikroszkópos vizsgálatok elvégzésére a vad típusú, valamint a $\Delta / \Delta$ sappla$\Delta / \Delta$ sapplb és $\Delta / \Delta$ sappla- $\Delta / \Delta$ sapp $1 b-\Delta / \Delta$ sapp 2 törzsek bevonásával. Előzetes vizsgálataink azt mutatták, hogy a mikroba sejtfalán található apró kitüremkedések, ún. ,pimple”-k száma a

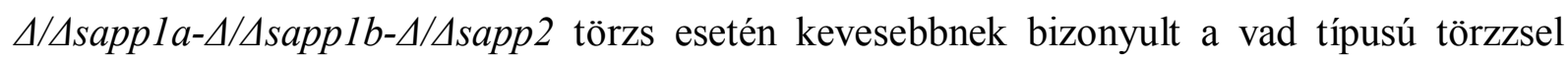
összevetve (33. ábra). Ezen sejtfali képleteket C. ablicans-ban Anderson és munkatársai írták le, a mikroorganizmus white-opaque átmenete során (Anderson és mtsai. 1990). Ezen képletek létrejötte valószínűleg az eltérő sejtfalszerveződés miatt jöhet létre, ám kialakulásuk pontos mechanizmusa ma sem ismeretes.

WT

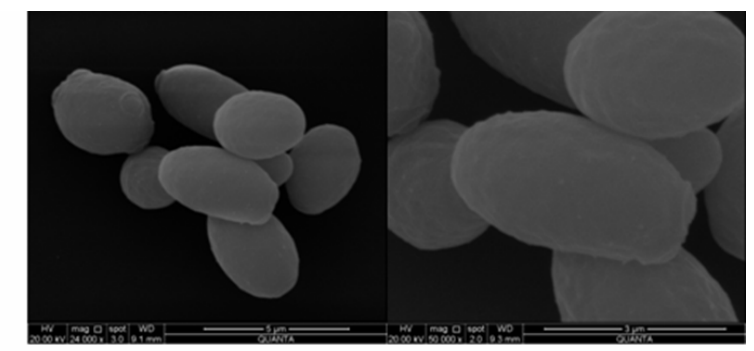

\section{$\Delta / \Delta$ sapp1a-} $\Delta / \Delta$ sapp1b

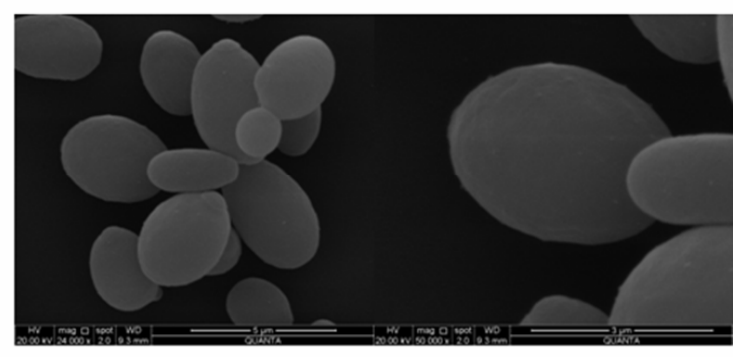

\section{$\Delta / \Delta$ sapp1a- $\Delta / \Delta \operatorname{sapp} 1 b-\Delta / \Delta$ sapp2}

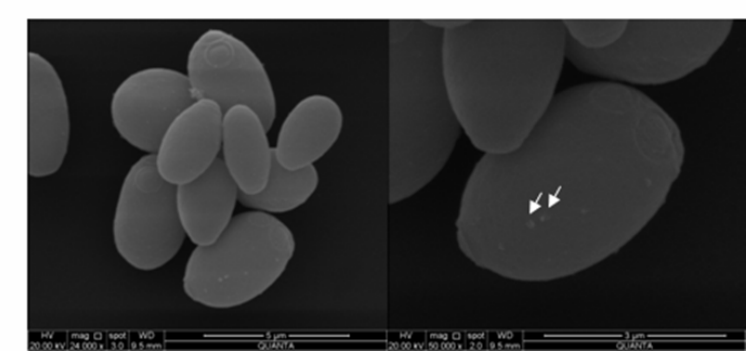

33. ábra

A vad típusú és a $\Delta / \Delta$ sappla- $\Delta / \Delta$ sapp $1 b$, valamint $\Delta / \Delta$ sappla- $\Delta / \Delta$ sapp $1 b-\Delta / \Delta$ sapp2 törzsek scanning elektronmikroszkópos vizsgálata.

Ezen jelenség egyik lehetséges magyarázata lehet, hogy a vad típusú törzshöz képest a deléciós mutáns törzsek esetén a szekréció folyamata zavart szenved az eltérő sejtfal összetételből adódóan. Ennek tisztázására elvégeztük a vad típusú és mutáns törzsek vezikula frakcióinak méret szerinti analízisét (34. ábra), valamint a törzsek sejtmembránjában található ergoszterin tartalom meghatározását (35. ábra). 

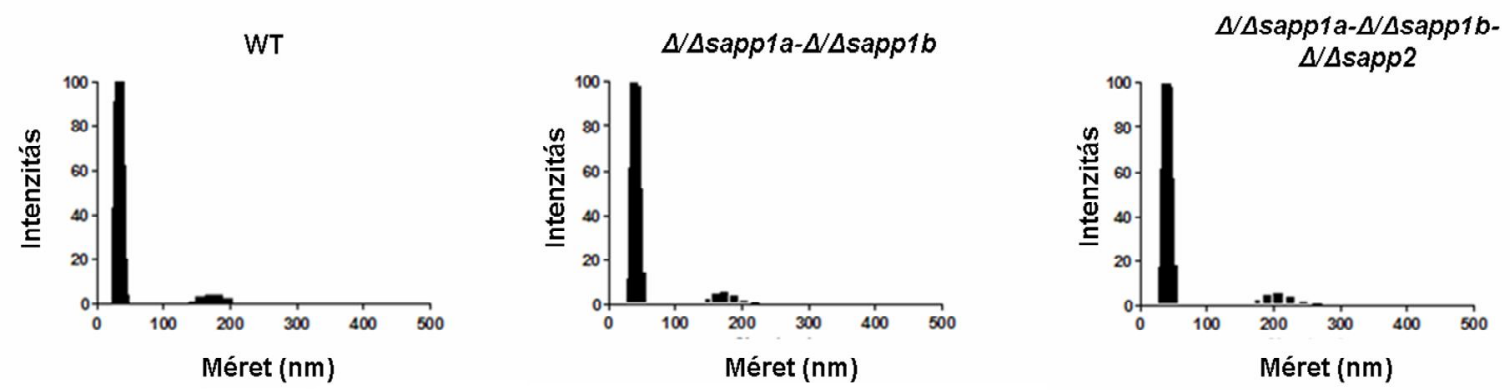

34. ábra

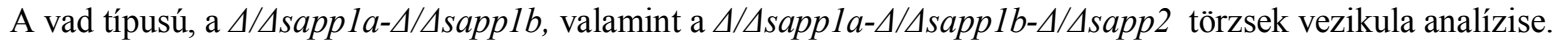

A törzsek vezikuláinak méret szerinti analízise nem mutatott különbséget a vad típusú és deléciós mutánsok között. Vizsgáltuk a törzsek membránjában található ergoszterin tartalmat, de szignifikáns különbséget nem tapasztaltunk (35. ábra).

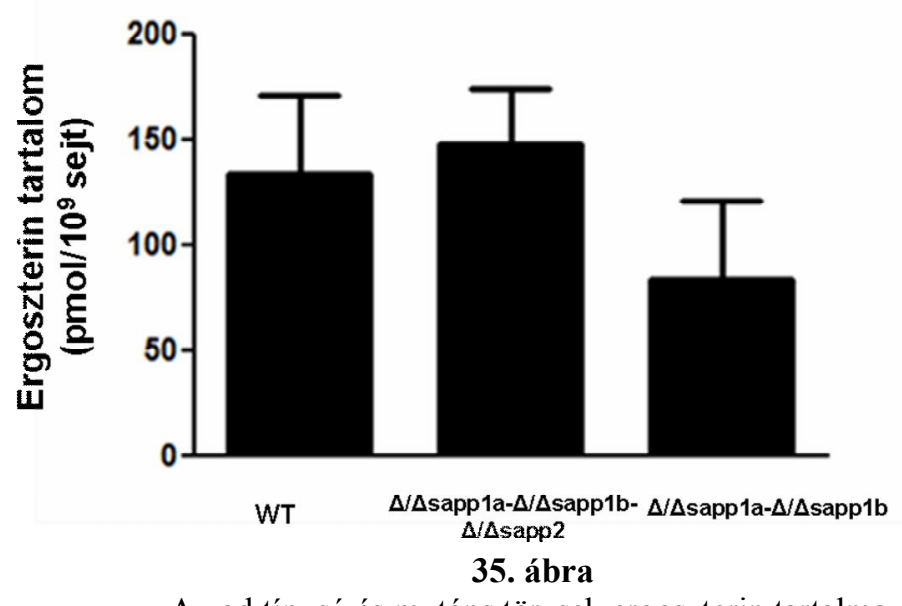

Mindezen eredmények arra mutatnak rá, hogy bár egyetlen C. parapsilosis szekretált aszpartil proteináz sem tartalmaz glikozil foszfatidil-inozitol oldalláncot, így a mikroba sejtfalába beépülni kovalens módon nem képes, mégis jelentős szerepet játszik a mikorba sejtfalának felépítésében. Az eddigi eredmények azt mutatják, hogy a szekretált aszpartil proteinázoknak nagy szerepük lehet a gomba sejtfalának belső, kompakt rétegének kialakításában és fenntartásában, mivel ezen proteinázok hiányában jóval kevesebb mennyiségű kitin és jóval nagyobb mennyiségű glükán tartalom figyelhető meg, így a mutáns törzsek sejtfala valószínüleg jóval lazább szerkezetü, mint a vad típus sejtfala. 


\subsection{Egy lehetséges overexpressziós rendszer alapjainak kidolgozása $C$. parapsilosis-ban}

A CUG kládba tartozó Candida fajok többsége diploid szervezet, melyek szexuális ciklussal nem rendelkeznek. A szexuális ciklus hiányából adódóan egy adott gén deléciója minden módszer esetén két transzformálás során valósítható meg, amelynek kivitelezése sok esetben jelentős időt vehet igénybe. Több kópiában jelen lévő gének esetén a deléció folyamata még ennél is több időt vesz igénybe. Erre lehet példa az előző fejezetben ismertetett $S A P P 1$ gén deléciója, melynek során a két kópia deletálása több, mint egy évet vett igénybe éa a deléciós stratégia sokszori újratervezése volt szükséges. További hátránya a géndeléciós eljárásoknak, hogy a deletált törzs bizonyos esetekben letális fenotípust mutat, vagy más esetekben, ha egy géncsalád egyik génjét deletáljuk, látható fenotípusos változás nem történik, mivel az adott géncsalád többi tagja kompenzálni képes az elvesztett gén funkcióját. Ezen problémák áthidalására nyújthat megoldást egy megbízható, jól müködő overexpressziós stratégia kidolgozása.

Napjainkra C. parapsilosis esetén számos, jól alkalmazható géndeléciós eljárás került kidolgozásra, ám overexpressziós mutáns törzsek létrehozása nem történt meg. Munkánk során célunk volt egy C. albicans-ban jól müködő overexpressziós rendszer C. parapsilosis-ra adaptálása. Ezen rendszer kidolgozásához Cabral és munkatársainak munkája adta az alapot (Cabral és mtsai. 2012). A C. albicans-ban müködő rendszer az RP10 (más néven RPS1) lokuszt használja, mint genetikailag semleges lokuszt, amelybe a túlmüködtetni kívánt gént inszertálják. A túlműködtetni kívánt gén egy megfelelően erős promoter szabályozása alatt áll.

Az overexpressziós rendszer ezen kívül kihasználja a Gateway (Invitrogen) klónozási rendszer specificitását és gyorsaságát. Ezen klónozási rendszer helyspecifikus rekombináció segítségével képes az amplifikált ORF-eket az adott vektorba inszertálni. Az első klónozási lépés során az „entry clone” létrehozása történik meg, az ún. BP klonáz enzim segítségével. Az entry klón létrehozása után az adott ORF-et az entry vektorból a „destination vektor”-ba szükséges átvinni, szintén egy specifikus rekombináz, az ún. LR klonáz segítségével. A destination vektor felhasználástól függően sokféle lehet. Mind a BP, mind az LR klonáz egy specifikus rekombináz, melyeket a $\lambda$-fágból tisztítottak (Hartley és mtsai. 2000). 


\subsubsection{C. parapsilosis overexpresszióra alkalmas fogadó törzsének létrehozása.}

Ahhoz, hogy egy C. albicans-ban jól müködő overexpressziós rendszert sikerrel adpatáljunk C. parapsilosis-ra, elsőként a $C$. albicans $R P 10$ régióját integráltuk a $C$. parapsilosis CLIB leucin auxotróf törzsébe (36. ábra).

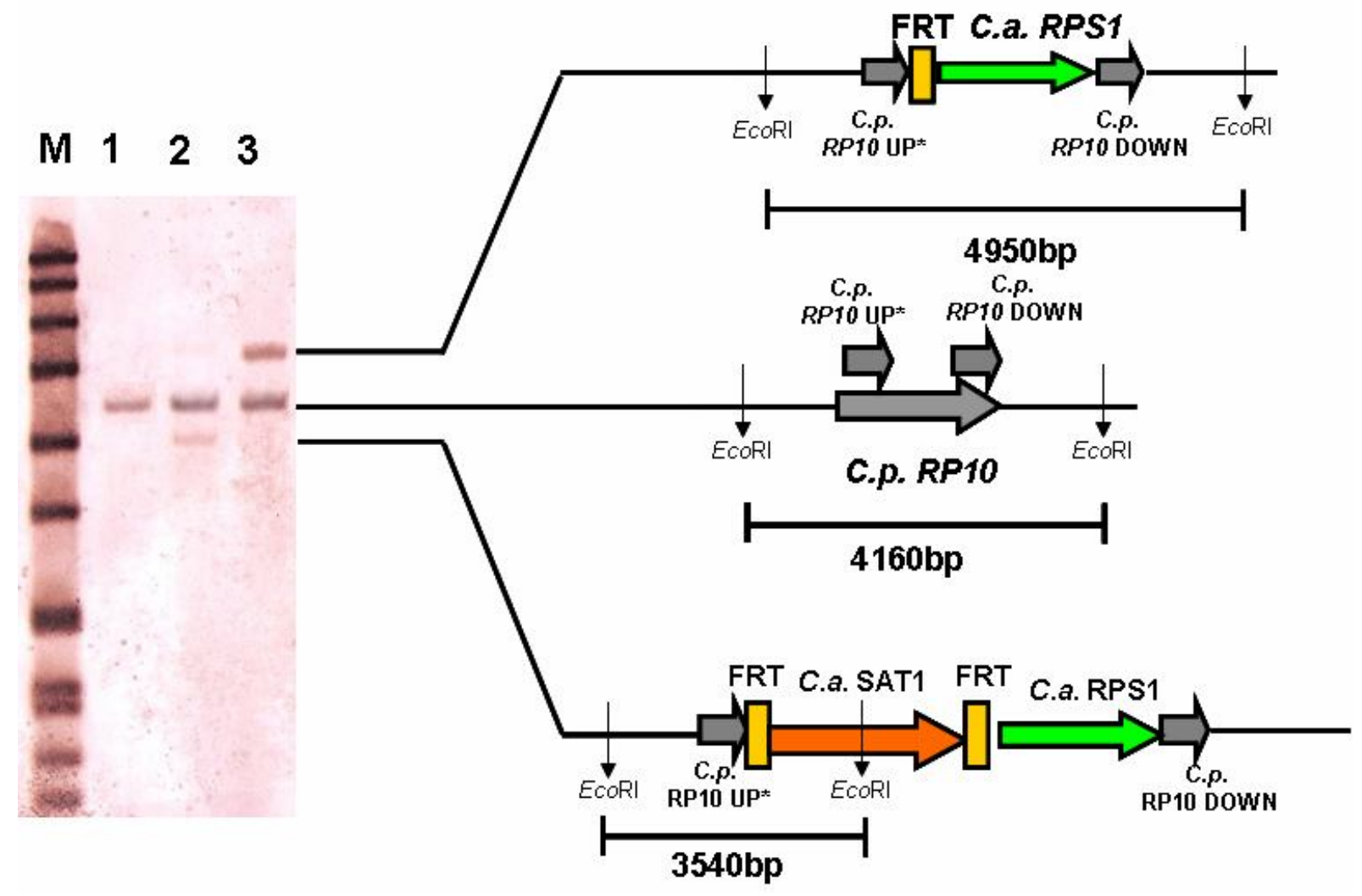

36. ábra

A C. parapsilosis fogadó törzsének előállítása CLIB leu- háttéren. M: DNA Molecular Weight Marker VII, DIG-

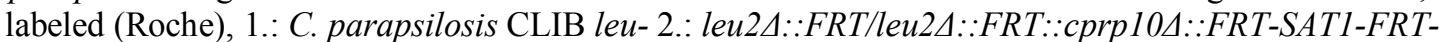
caRP10/cpRP10 3.: leu2A::FRT/leu2A::FRT::cprp10A::FRT-caRP10/cpRP10

A C. albicans RP10 régiójának integrálásához a pSFS2 vektort használtuk fel (a vektort Joachim Morsscauser bocsátotta rendelkezésünkre). Az üres pSFS2 vektorba ez esetben a $C$. parapsilosis RP10 régiójának upstream részét (319bp) a vektor KpnI - XhoI helyére klónoztuk. Ugyanezen régió downstream részét (326bp) a vektor SacI helyére klónoztuk. A $C$. albicans RP10 régióját (770 bp) közvetlenül a vektoron elhelyezkedő caSAT1 kazetta mögé, NotI helyre klónoztuk be (37. ábra). 


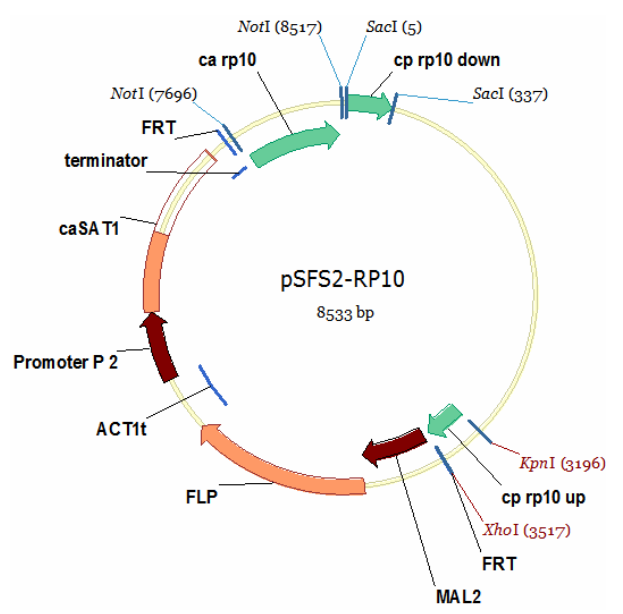

37. ábra

A C. parapsilosis fogadó törzséhez felhasznált konstrukció

A C. parapsilosis RP10 upstream és downstream régióit felhasználva a korrekt integráció lehetségessé vált. A caSAT1 kazetta eliminációja után, a NAT szenzitív transzformáns heterozigóta formában, a $C$. parapsilosis $R P 10$ génjének egyik alléljébe integráltan hordozza a $C$. albicans $R P 10$ régióját, ezáltal ezen transzformánsnak ez az allélje képes fogadni a $C$. albicans-ban is müködő overexpressziós vektort.

\subsubsection{Az elkészített $C$. parapsilosis fogadó törzs GFP transzformációja}

A C. parapsilosis fentebb leírt módszerrel elkészített fogadó törzsének teszteléséhez, azaz annak kiderítéséhez, hogy a törzs képes-e fogadni az overexpressziós konstrukciókat, egy azokhoz nagyon hasonló, GFP riporter gént tartalmazó vektort használtunk fel (38.ábra).

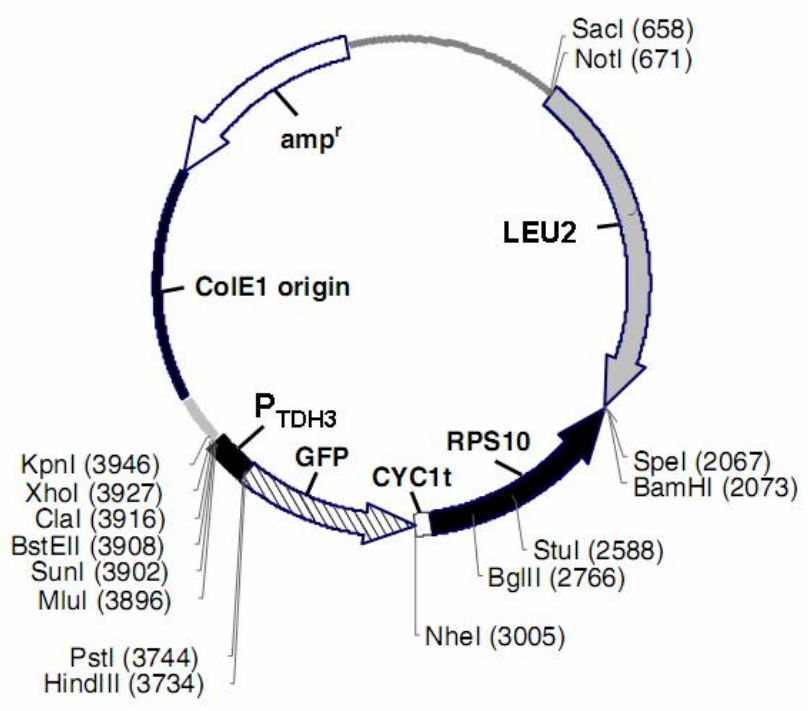

38. ábra

A C. parapsilosis fogadó törzsének teszteléséhez felhasznált Clp10- pTDH3-GFP konstrukció. 
Az eredeti GFP vektort Barelle és munkatársai alkották meg (Barelle és mtsai. 2004). A konstrukción található TDH3 promoter egy erős, konstitutív promoter, amely biztosítja a GFP riporter gén kifejeződését. A konstrukcióra jellemző, hogy a C. albicans RP10 régiója egy mesterségesen beépített StuI hasítóhelyet tartalmaz. Az eredeti vektor URA3 szelekciós markert tartalmazott, amelyet a szelekció biztosítása érdekében $C$. dubliniensis-ből származó LEU2 markerre (2266 bp) cseréltünk, amely markert NotI - SpeI helyekre klónoztunk.

A vektor szelekciós markerének cseréje után, annak SpeI enzimmel történő linearizációját követően az így elökészített GFP konstrukciót a $C$. parapsilosis fogadó törzsébe transzformáltuk (39. ábra).

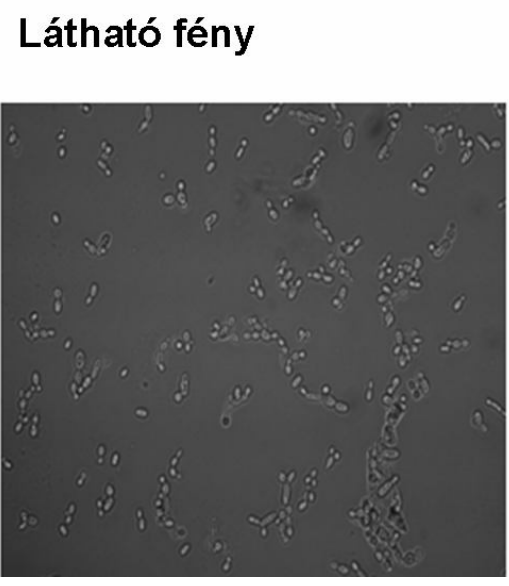

GFP

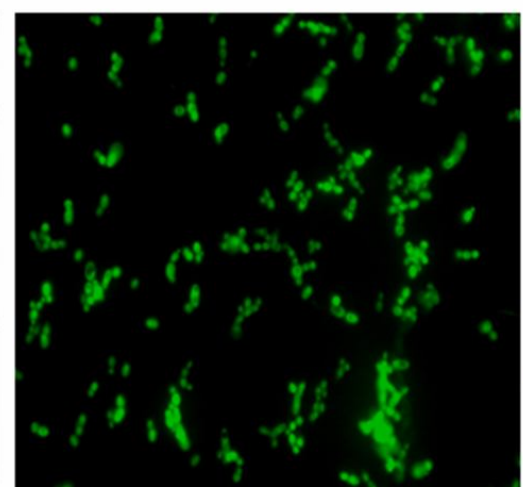

39. ábra

\section{Egymásra vetített kép}

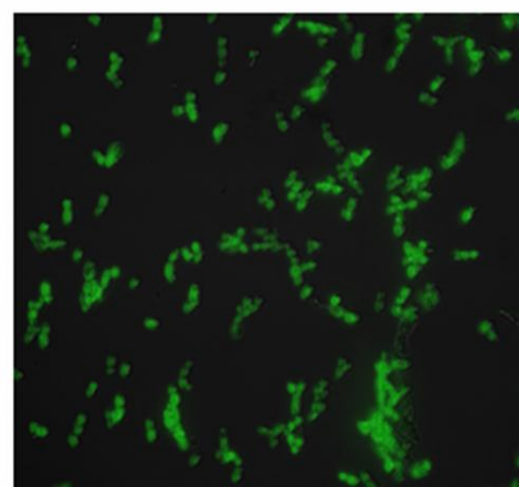

A C. parapsilosis fogadó törzsének Clp10-pTDH3-GFP-LEU2 konstrukcióval való transzformánsa.

A transzformációt követően a transzformánsokat fluoreszcens mikroszkópiával vizsgáltuk. A GFP pozitív transzformánsok minden sejtje azonos módon expresszálta a GFP proteint. Ez az eredmény bebizonyította, hogy az elkészített, C. albicans RP10 gént hordozó fogadó törzs alkalmas hátteret biztosít overexpressziós mutánsok létrehozásához.

\subsubsection{Az első overexpressziós vektor létrehozása}

Overexpressziós vektorok létrehozásához az Invitrogen által kifejlesztett nagy specificitással rendelkező gateway rendszert kívánjuk alkalmazni. A gateway rendszer előnye, hogy ellentétben a klasszikus klónozási lépésekkel - restrikciós emésztés, ligálás - ezen rendszer a klónozási lépéshez helyspecifikus rekombinázokat használ, melyek a $\lambda$-fágból származnak. $\mathrm{A}$ gateway klónozásra jellemző, hogy két vektort: egy „entry” és egy „,destination” vektort alkalmaz. Az entry vektor egy klónozó vektor, amely az adott fragment felszaporítását szolgálja, míg a destination vektor egy célzott, felhasználástól függően egyedi szekvenciájú vektor. Az entry vektor létrehozása a BP reakció során valósul meg. A klónozni kívánt 
fragment két végén található attB1 és attB2 rekombinációs felismerő helyek, valamint az üres entry vektor attP1 és attP2 felismerő helyek szolgálnak az irányított rekombináció helyéül. Az üres entry vektor tartalmazza a $c c d B$ gént, amely egy $E$. coli DNS giráz inhibitor, ezáltal az üres vektor toxikus a laborokban használatos $E$. coli törzsekre. Az elkészült, kívánt fragmentet tartalmazó entry vektort ezután az LR reakció során lehet felhasználni. Ezen reakcióban a felhasználni kívánt fragment destination vektorba történő rekombinációja zajlik le.

Munkánk során a WORl gén gateway rendszerrel való klónozását, illetve esetleges overexpresszáltatását kívántuk végrehajtani. A WOR1 gén C. albicans esetén felelős a witheopaque átmenetért, az a és $\alpha$ sejteket stabilan opaque fázisban képes tartani (Huang és mtsai. 2006). Ezen gén overexpresszáltatása érdekében a $C$. parapsilosis attB1 és attB2 rekombinációs helyeket tartalmazó C. parapsilosis WOR1 ORF-et a pDONR 221 vektorba (Invitrogen) klónoztuk. A sikeres klónozást követően LR reakció során az ORF-et a pTDH3GTW-LEU2 destination vektorba vittük át (40. ábra).

A

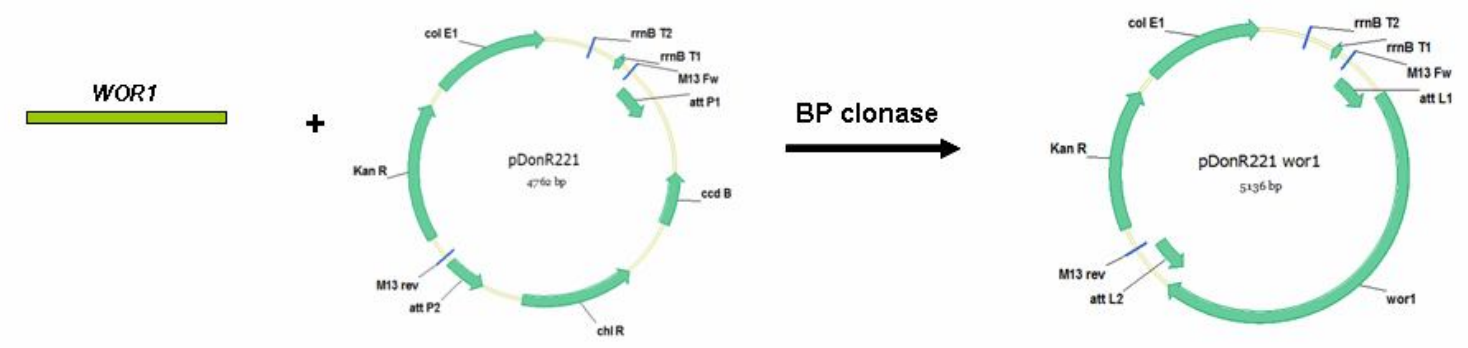

B

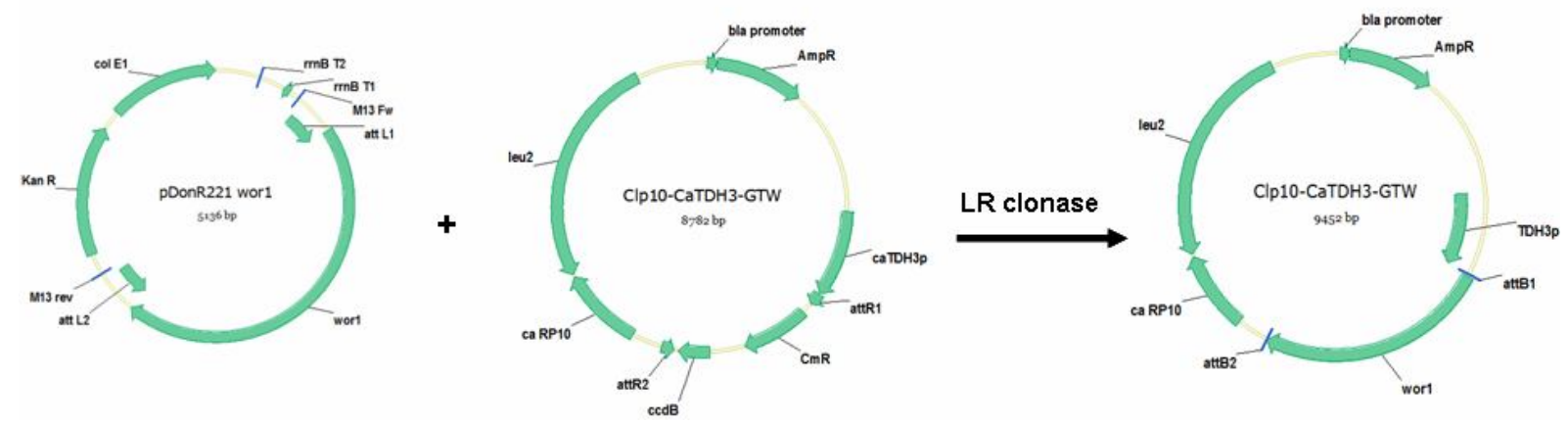

40. ábra

A WORl ORF-ének gateway klónozása. A: BP klonáz reakció, B: LR klonáz reakció.

Az elkészített, WORl gént hordozó „destination” vektorral ezután elvégeztük a $C$. parapsilosis fogadó törzsének transzformációját. A beépült vektor egy igen erős, konstitutív 
promotert tartalmaz. A transzformánsok WORl génjének transzkripciós szintjét qRT-PCR segítségével vizsgáltuk (41. ábra). A Kvantitatív Real-Time PCR eredmények szerint a transzformáns telepek esetén a vad típushoz képest a $C$. parapsilosis WORl expressziós szintje szignifikánsan, mintegy tízszeresére emelkedett $(* *: \mathrm{P}<0,01)$. A kapott eredmény azt mutatja, hogy az ezen a módon létrehozott fogadó törzs képes múködtetni az integrált gént, amely a TDH3 konstitutív promoter szabályozása alatt konstitutívan kifejeződik.

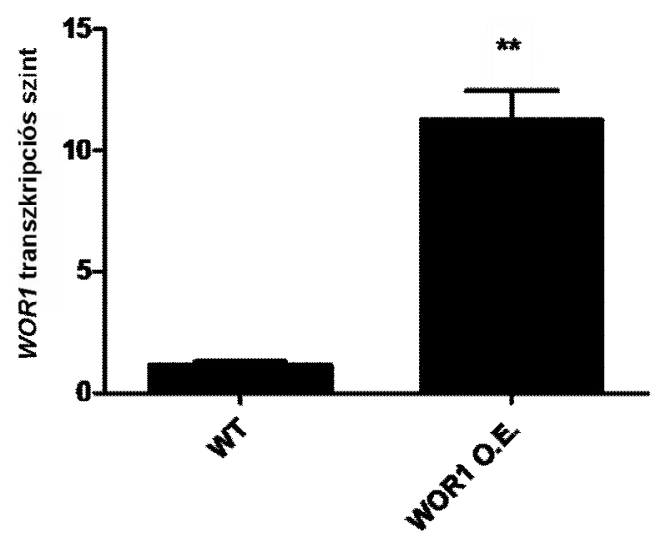

41. ábra

A C. parapsilosis fogadó törzsének WOR1 gént hordozó overexpressziós transzformánsának génexpressziós vizsgálata. A transzformánsokban a WORl gén expressziója szignifikánsan emelkedett (**: $\mathrm{P}<0,01)$.

A kapott eredmény jól mutatja, hogy $C$. parapsilosis esetén mind a létrehozott fogadó törzs, mind az alkalmazott overexpressziós stratégia jól alkalmazható későbbi munkák során overexpressziós mutánsok létrehozásához, lehetőséget biztosítva ezzel egy adott gén funkciójának alaposabb tanulmányozásához, ezzel együtt a gazda-patogén kölcsönhatás mélyebb megértéséhez. 


\section{7. ÖSSZEFOGLALÁS}

A Candida fajok által kiváltott megbetegedések az elmúlt három évtized során egyre növekvő egészségügyi problémát jelentenek. Bár ezen élesztők többsége a normál, humán mikroflóra része, bizonyos körülmények között a bőrt, nyálkahártyát, vagy az egész szervezetet érintő, szisztémás fertőzések kiváltására képesek. Gyakran hozhatók összefüggésbe nozokomiális fertőzésekkel, így az elhúzódó kórházi kezelés, nyílt/égési sérülések, valamint koraszülött csecsemők esetén az alacsony születési súly szintén a rizikófaktorok között szerepel. Epidemiológiai vizsgálatok szerint, bár a felnőtt lakosság körében a kandidiázisos esetek legnagyobb hányadát a $C$. albicans okozza, addig újszülöttek körében a kandidiázisos kórképek kialakulásáért felelős ágensek körében a C. parapsilosis sok esetben a C. albicans által kiváltott esetszámot is felülmúlja. 2005-ben a C. parapsilosis-t, genetikai varianciája alapján három csoportra osztották: C. parapsilosis, C. orthopsilosis, $C$. metapsilosis. A három faj közösen a C. parapsilosis sensu lato csoportot alkotja. Bár az ezredforduló óta a nem-albicans fajok (újszülöttek körében fóként a $C$. parapsilosis) által okozott megbetegedések aránya növekvő tendenciát mutatnak, azok patomechanizmusáról, virulencia faktorairól kevés ismeret áll rendelkezésünkre. C. parapsilosis által kiváltott fertőzések esetén jelentős szerep jut a mikroba által szekretált hidrolitikus enzimeknek, főként a lipázoknak és szekretált aszpartil proteinázoknak. Korábbi tanulmányok lipáz deficiens $C$. parapsilosis törzs esetén jelentős virulencia csökkenést mutattak ki. Szekretált aszpartil proteinázok esetén a $C$. parapsilosis két fó proteinázának, a Sapp1 és Sapp2 fehérjéknek enzimológiai tisztítása és jellemzése történt meg. Bár $C$. parapsilosis esetén napjainkra számos géndeléciós módszert dolgoztak ki, ám C. albicans-al ellentétben overexpressziós módszer ezen mikroba esetén nem áll rendelkezésre. Ezen okokból kifolyólag munkánk kezdetén a következő célkitüzéseket tettük: célunk volt 1.: a C. parapsilosis fő szekretált aszpartil proteinázának, a Sapp1 fehérjének virulenciában betöltött szerepének tisztázása, 2.: a C. parapsilosis szekretált aszpartil proteinázainak virulenciában betöltött általános szerepének tisztázása egy Sapp negatív törzs létrehozásával, valamint 3.: egy C. parapsilosisra optimalizált overexpressziós rendszer alapjainak kidolgozása. Az említett célkitüzések eredményei a következők. 


\subsection{A $C$. parapsilosis szekretált aszpartil proteináz 1 (Sapp1) virulenciában}

betöltött szerepének vizsgálata.

Munkánk kezdetén a C. albicans által szekretált aszpartil proteinázok (Sap) virulenciában betöltött szerepe régóta tanulmányozott volt (Hube and Naglik 2001). C. albicans-ban végzett vizsgálatok azt mutatták, hogy ezen fajban a szekretált aszpartil proteinázok virulenciában betöltött szerepe igen sokrétü, számos, a gazdaszervezetben megtalálható strukturális és antimikrobiális proteinek bontására képesek, ezáltal elősegítve a mikroba szervezeten belüli terjedését (Hube 1998, Naglik és mtsai. 2003).

C. parapsilosis esetén ebben az időben (2009) Olga Hruskova-Heidingsfeldova és munkatársai sikeresen azonosították, tisztították és jellemezték a $C$. parapsilosis Sapp1 és Sapp2 fehérjéit (Dostal és mtsai. 2005, Hruskova-Heidingsfeldova és mtsai. 2009), ám a szekretált aszpartil proteinázok virulenciában betöltött szerepéről információ nem állt rendelkezésre. Az enzimológiai vizsgálatok szerint a mikroba fó szekretált aszpartil proteináza a Sapp1 fehérje, amely induktív körülmények közt legalább egy nagyságrenddel nagyobb mértékben termelődik, mint a Sapp2 fehérje, valamint szubsztrát specifitása is sokkal szélesebb (Hruskova-Heidingsfeldova és mtsai. 2009).

Mindezen adatokból kiindulva munkánk első felében célul tüztük ki a C. parapsilosis fö szekretált aszpartil proteinázának, a Sapp1 fehérjének virulenciában betöltött szerepét. Elözetes Southern hibridizációs vizsgálataink során felmerült annak a lehetősége, hogy a $S A P P 1$ gén két kópiában van jelen a genomban, ezért a rendelkezésünkre álló szekvencia adatok felhasználásával elvégeztük a SAPP1 lokusz in silico analízisét. Az analízis két identikus 2871 bp méretű szekvenciát azonosított, egymástól 32kb távolságra, amely szakasz egy-egy kópiában tartalmazta a $S A P P 1$ gént, így a két kópiát $S A P P 1 a$ és $S A P P 1 b$ néven különítettünk el egymástól. Geraldine Butler és munkatársai 2009 végén publikálták a $C$. parapsilosis annotált genomszekvenciáját (Butler és mtsai. 2009), amely adatok megerősítették az in silico vizsgálat helyességét.

Annak érdekében, hogy a Sapp1 fehérje virulenciában betöltött szerepéről felvilágosítást nyerjünk, a caSAT1 flipper rendszer segítségével elvégeztük a SAPPla és

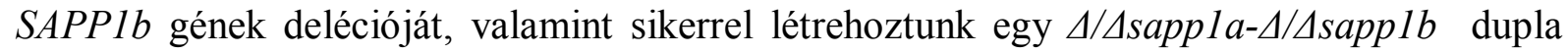
deléciós törzset is. A SAPP1 gének elvesztését RNS és fehérje szinten egyaránt megerősítettük, qRT-PCR, valamint a Sapp1 és Sapp2 fehérjék enzimaktivitásának vizsgálatára alkalmas HPLC vizsgálat során. A dupla deléciós törzs esetén sem RNS, sem enzim aktivitási szinten nem tudtunk kimutatni SAPP1 génexpressziót, illetve Sapp1 fehérje aktivitást. Érdekes módon a dupla deléciós törzs esetén a vad típushoz képest emelkedett 
mértékü SAPP2 génexpressziót, valamint enzim aktivitás emelkedést tapasztaltunk. Ezen jelenség hátterében valószínűsíthetően egy visszacsatoló mechanizmus állhat, amely müködésének eredményeként a Sapp2 fehérje emelkedett termelését vagy a már megtermelt enzim aktivitásának fokozódását eredményezte, amely mintegy kompenzációs mechanizmus szolgál a Sapp1 elvesztésére. Ez a jelenség felhívja a figyelmet arra, hogy akárcsak $C$. albicans esetén (Naglik és mtsai. 2003), C. parapsilosis-ban a szekretált aszpartil proteinázok kifejeződése szigorú szabályozás alatt áll. Ezen felül vizsgáltuk a putatív szekvenciaként számon tartott SAPP3 gén transzkripciós változását is. A vad típus esetén, induktív körülmények között tízszeres transzkripciós növekedést tapasztaltunk, míg azon mutánsok esetén, melyek $\triangle / \triangle$ sapplb deléciót hordoztak, a $S A P P 3$ gén expressziója szignifikáns mértékben csökkent. További szekvencia analízis vizsgálatok kimutatták, hogy a SAPP3 csupán minegy 500 bázispár távolságban helyezkedik el a SAPP1b lokuszhoz tartozó duplikálódott régiótól. Mivel a $S A P P 1 b$ lokusz deléciója csupán a duplikálódott régió deléciójával volt kivitelezhető, így ezen deléció érinthette a $S A P P 3$ gén szabályozó régióját is.

C. albicans esetén régóta tudott, hogy a szekretált aszpartil proteinázok képesek a szérumban található számos komplement komponens bontására, ezáltal semlegesítve a gazda szervezet humorális védekezését (Gropp és mtsai. 2009). Annak kiderítésére, hogy a Sapp1 fehérje rendelkezik-e hasonló szereppel elvégeztük a vad típusú és a különböző Sapp1 mutáns törzsek szérumérzékenységének vizsgálatát. Eredményeink azt mutatták, hogy intakt humán szérum jelenlétében a vad típusú, és a $\Delta / \Delta$ sappla és $\Delta / \Delta s a p p 1 b$ törzsek növekedése közt nem mutatkozott különbség, viszont a $S A P P 1$ deléciós mutáns törzs esetén a növekedés mértéke jelentős mértékben visszaesett. A kapott eredmény arra enged következtetni, hogy a $C$. parapsilosis Sapp1 fehérjéjének, hasonlóan a C. albicans Sap fehérjékhez szerepe lehet a szérumban megtalálható komplement komponensek bontásában. A jelenség pontos okának kiderítése további biokémiai vizsgálatokat igényel tisztított Sapp1 fehérje, valamint tisztított komplement komponensek és egyéb, szérumban található antimikrobiális peptidek (pl. defenzinek) bevonásával.

Egy fertőzés folyamatában a szervezetbe kerülő patogénekkel elsőként makrofágok kerülnek kapcsolatba. A szervezetbe jutott kórokozók felszínükön evolúciósan nagy mértékben konzervált motívumokat, patogén-asszociált molekuláris mintázatokat (PAMP) hordoznak, melyeket a makrofág sejtek mintázatfelismerő receptorokkal (PRR) ismernek fel. A felismerést követően lezajlik a mikroba fagocitózisa. A primer fagoszóma lizoszómával való fúziója $\mathrm{pH}$ csökkenéssel jár, melynek során megtörténik a patogén eliminációja (Netea és mtsai. 2008). Hogy ezen folyamatokat tanulmányozzuk, PBMC és PBMC-DM sejtek 
felhasználásával in vitro fagocitózis vizsgálatokat végeztünk. A vizsgálathoz a vad típusú, valamint a deléciós törzseket használtuk fel. Áramlási citometriás méréseink szerint a vad típushoz képest a $S A P P 1$ deléciós törzsek fagocitózisa jóval eredményesebben valósult meg. A fagocitózis folyamatának részletesebb tanulmányozása érdekében fluoreszcens mikroszkópos vizsgálatokat végeztünk PBMC-DM sejtek és vad típusú, valamint deléciós $C$. parapsilosis törzsek felhasználásával. A vad típussal fertőzött mintákhoz képest a Sapp1 fehérjét nem termelő mutáns törzzsel fertőzött PBMC-DM sejtek esetén emelkedett mértékü fago-lizoszóma fúziót figyeltünk meg. Ismeretes, hogy a fagoszóma lizoszómával történő fúziójához számos, a vezikulák felszínén található receptor-ligand kötődése szükséges (Fernandez-Arenas és mtsai. 2009). Az általunk végzett megfigyelés felveti annak a lehetőségét, hogy a Sapp1 fehérjének szerepe van a mikroba fagocita sejten belüli túlélésében is.

PBMC és PBMC-DM sejtek alkalmazásával vizsgáltuk a gazda sejtek vad típusú és deléciós mutánsokkal szembeni gombaölési képességét. Mind a PBMC, mind az ezekből differenciáltatott primer makrofágok esetén a dupla deléciós mutánsokkal szembeni gombaölési képesség szignifikáns emelkedést mutatott. Ezzel párhuzamosan a SAPP1 deléciós törzs gazdasejtet károsító képessége csökkenést mutatott a vad típusú törzzsel összevetve.

Mindezen eredményeket összevetve eredményeink azt mutatják, hogy a Sapp1 fehérje jelentős szereppel bír a mikroba virulenciájának kialakításában. Szerepe van a gazda antimikrobiális peptidjeinek semlegesítésében, a fagocitózis gátlásában, valamint nagy mértékben hozzájárul a patogén fagocita sejten belüli túlélésében egyaránt.

\subsection{A C. parapsilosis „Sapp negatív” szekretált aszpartil proteinázt nem termelő} mutáns törzsének virulencia vizsgálata.

C. albicans esetén tíz SAP gént azonosítottak (SAP1-SAP10), melyek egy géncsaládot alkotnak (Hube és Naglik 2001). Bár ezen organizmusban a SAP gének szerepe jól tanulmányozott, mégis egy teljes mértékben $S A P$ deficiens törzs előállítása a gének nagy számából adódóan nem lehetséges. A C parapsilosis genomjában mindösszesen két SAPP gén van jelen, amelyekről bizonyítottan aktív szekretált proteináz képződik, illetve egy feltételezhetően szekretált Sapp fehérjét kódoló gént azonosítottak, így ebben a fajban egy $S A P P$ deficiens törzs előállítása, ezáltal egy olyan modellrendszer kialakítása, melyben a szekretált aszpartil proteinázok virulenciában betöltött általános szerepe tanulmányozható, jóval eredményesebben megvalósítható feladat. Ezen cél elérése érdekében munkánk második 
felében a $\Delta \Delta$ sappla- $\Delta \Delta s a p p 1 b$ törzset kiindulási törzsként alkalmazva, a caSAT1 flipper rendszer segítségével elvégeztük a $S A P P 2$ gén delécióját.

A SAPP2 gén delécióját Southern hibridizáción kívül ebben az esetben is megerősítettük mind transzkripciós szinten, mind enzim aktivitási szinten. A $\Delta / \Delta$ sappla-

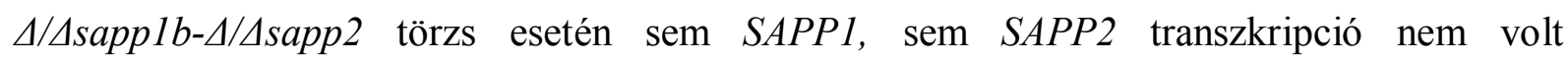
detektálható, valamint a SAPP3 gén transzkripciós szintje szignifikáns csökkenést mutatott. Ezen kívül a $\Delta / \Delta$ sapp $1 a-\Delta / \Delta \operatorname{sapp} 1 b-\Delta / \Delta$ sapp2 törzs esetén nem detektáltuk sem a Sapp1, sem a Sapp2 fehérjékre jellemző enzimaktivitást. A létrehozott mutáns tehát mind expressziós mind enzimaktivitás tekintetében „Sapp negatív”-nak nevezhető.

Bár elöző munkánk során létrehoztunk egy Sapp1 hiányos C. parapsilosis törzset, vizsgálni kívántuk ezen munka keretében, hogy a további szekretált aszpartil proteináz fehérjék elvesztésének van-e további hatása a mikroba humán szérumban mért növekedésére. Intakt humán szérum esetén a $\Delta / \Delta \operatorname{sapp} 1 a-\Delta / \Delta \operatorname{sapp} 1$ b- $\Delta / \Delta$ sapp 2 mutáns törzs növekedése bár a vad típusú törzshöz képest szignifikáns csökkenést mutatott, összevetve az előző munkánk során mért SAPP1 deléciós törzs szérumban mutatott növekedéssel, különbség nem volt megállapítható. Ez az eredmény azt sugallja, hogy a Sapp1 fehérje az, amely hatékonyan képes semlegesíteni a gazda szervezet antimikrobiális peptidjeit. Ez a megfigyelés összhangban áll Olga Hruskova-Heidingsfeldova és munkatársai által kapott eredményekkel, miszerint a Sapp1 fehérje, összehasonlítva a Sapp2 fehérjével nem csak egy nagyságrenddel nagyobb mennyiségben termelődik, ám annak szubsztrát specificitása is jóval szélesebb (Hruskova-Heidingsfeldova és mtsai. 2009)

A gazda - patogén kölcsönhatás tanulmányozása érdekében jelen munka során szintén elvégeztük az in vitro makrofágokkal történő interakció vizsgálatát. A fagocitózis folyamatának tanulmányozásához áramlási citometriás módszert alkalmaztunk. Eredményeink azt mutatják, hogy a Sapp negatív $\Delta / \Delta$ sappla- $\Delta / \Delta \operatorname{sapp} 1 b-\Delta / \Delta \operatorname{sapp} 2$ törzset jóval nagyobb mértékben fagocitálják a gazda sejtek, mint a vad típusú törzset, ám összevetve ezen deléciós mutánst az előző munkánkban létrehozott $S A P P 1$ deléciós $\triangle / \Delta$ sappla- $\Delta / \triangle \operatorname{sapplb}$ törzzsel a fagocitózis százalékában nem mutatkozik különbség, amely szintén arra utal, hogy a $C$. parapsilosis virulenciájában a szekretált aszpartil proteinázok közül a Sapp1 tölti be a legnagyobb szerepet. Pietrella és munkatársai kimutatták, hogy C. albicans esetén a Sap1, Sap2 és Sap6 megnöveli a primer monociták által termelt IL-1 $\beta$, TNF- $\alpha$ és IL-6 mennyiségét, továbbá a Sap3 szintén indukálja az IL-1 $\beta$ és TNF- $\alpha$ termelését (Pietrella és mtsai. 2010) Hogy kiderítsük, vajon $C$. parapsilosis esetén a Sapp fehérjéknek van-e hasonló szerepe ELISA módszerrel mértük a fertőzés során termelődő proinflammatorikus citokinek (IL-1 $\beta$, 
TNF- $\alpha$ és IL-6) mennyiségét. A vad típushoz képest szignifikáns különbséget nem tapasztaltunk a Sapp negatív mutáns törzzsel fertőzött mintában, ám a Sapp fehérjék citokin válaszban betöltött szerepének tanulmányozásában ez csupán mint egy előzetes vizsgálat játszott szerepet. A Sapp fehérjék által indukált citokin termelődés vizsgálatának alaposabb tanulmányozásához mindenképpen szükséges vizsgálni az anti-inflammatorikus citokinek mennyiségét is, valamint célszerü a kísérleti rendszert más sejtvonalakkal is bővíteni.

Vizsgáltuk továbbá a vad típusú és deléciós mutáns törzsek PBMC-DM sejtek általi ölési hatékonyságát. A Sapp negatív halmozottan deléciós mutáns törzs esetén a gazdasejtek általi gombaölési hatékonyság szignifikáns emelkedést mutatott. Összevetve az előző munkánkban tapasztalt $\Delta / \Delta$ sappla-A/4sapplb törzzsel szembeni ölési hatékonysággal, ebben az esetben a Sapp negatív törzzsel szembeni eliminációs hatékonyság további növekedést mutatott, amely azt bizonyítja, hogy a Sapp1 mellett további szekretált proteinázok is szereppel bírnak a mikroba makrofágon belüli túlélésében. Ez a megfigyelés összecseng a $C$. albicans-ban már leírt jelenséggel, miszerint a különböző Sap fehérjék a fertőzés térben és időben jól elkülöníthető fázisaiban játszanak fontos szerepet. Vizsgáltuk ezen felül a deléciós törzs gazdasejt károsító képességét is. A Sapp negatív törzs gazdasejtet károsító képessége a vad típuséhoz képest szignifikáns csökkenést mutatott, ám összevetve az előző tanulmányban vizsgált Sapp1 deléciós mutáns törzzsel, a két deléciós törzs gazdasejt károsító képessége eltérést nem mutatott.

Galleria mellonella (Nagy viaszmoly) lárvák felhasználásával in vivo túlélési vizsgálatot is elvégeztünk, ám a vad típusú törzzsel fertőzött és a deléciós törzzsel fertőzött egyedek túlélése között szignifikáns eltérést nem tapasztaltunk.

Bár a CUG kládba tartozó Candida fajok esetén yapszin típusú proteineket nem találunk (Naglik és mtsai. 2003), mégis C. albicans esetén a Sap9 és Sap10 fehérjékről ismert, hogy glikozil-foszfatidil-inozitol oldalláncot hordoznak, ezáltal a sejtfalba beépülni és a sejtfal integritását fenntartani képesek (Schild és mtsai. 2011). C. parapsilosis esetén, bár sem a Sapp1, sem a Sapp2 fehérje nem hordoz ilyen oldalláncot, a Sapp1 esetén kimutatták, hogy a fehérje képes a mikroba sejtfalában feldúsulni (Vinterova és mtsai. 2011). Ehhez kapcsolódóan, egy kollaborációs partnerünk, Prof. Olga Hruskova-Heidingsfeldova Sapp3 fehérjével végzett előzetes kutatási eredményei azt mutatják, hogy a Sapp3 fehérje ugyancsak képes a sejtfalban lokalizálódni (nem közölt adat, személyes megbeszélés). Mindezen adatok arra utalnak, hogy mind a $\Delta / \Delta$ sappla- $\Delta / \Delta$ sapp 1 , mind a $\Delta / \Delta$ sapp $1 a-\Delta / \Delta \operatorname{sapp} 1$ b- $\Delta / \Delta$ sapp 2 deléciós törzs sejtfal összetétele különbözik a vad típusú törzsétől. Ezen okból elvégeztük a

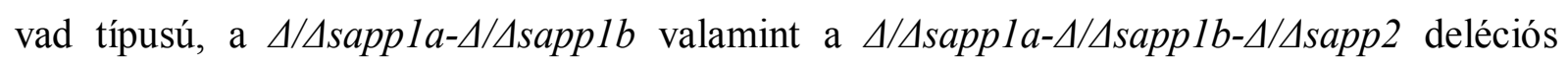


törzsek sejtfalösszetételének vizsgálatát. A vad típusú törzshöz képest a két deléciós mutáns törzs sejtfalösszetétele jelentős különbségeket mutatott. Mindkét deléciós törzs esetén a sejtfalban található kitin tartalom jelentősen lecsökkent, míg a glükán tartalom a $\Delta / \Delta$ sappla-

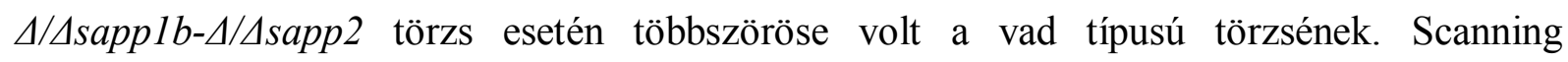
elektronmikroszkópos vizsgálataink szerint ugyanezen deléciós törzs sejtfalának felszíne jóval kevesebb sejtfalkitüremkedést mutat, mint a vad típusú törzs.

Mindezen adatok alátámasztják a $C$. parapsilosis szekretált aszpartil proteinázok sokrétü szerepét. Bár alapvető szerepük a peptidkötések hidrolízise, mégis vizsgálataink szerint ezen aszpartil proteinázok jelentős szereppel bírnak a mikroba virulenciájának kialakításában. Szerepük van a gazda szervezet szérumban található antimikrobiális fehérjéinek bontásában, a fagocitózis gátlásában, valamint a mikroba fagocita sejten belüli bontásában egyaránt. Másik fontos szerepük, amelyre vizsgálataink fényt derítettek a mikroba sejtfal összetételének szabályozásában áll. A sejtfal összetétel szekretált aszpartil proteinázok általi szabályozásának pontos mechanizmusa ezidáig nem ismert, így ezek további vizsgálatok tárgyát képezhetik a jövőben.

\subsection{C. parapsilosis overexpressziós rendszer alapjainak kidolgozása.}

A CUG kládba tartozó Candida fajok többsége diploid organizmus, melyek szexuális ciklussal nem rendelkeznek. Bár ezen fajok esetén számos géndeléciós módszert kidolgoztak (Noble és Johnson 2005, Gácser és mtsai. 2007c), mégis egy adott gén deléciója sok esetben (pl. több kópiában jelen lévő gének esetén) hosszú időt vehet igénybe, valamint olyan gének esetén, melyek egy nagyobb géncsalád tagjai, a létrehozott deléciós mutáns esetében mérhető fenotipikus változás sok esetben nem jelentkezik annak következtében, hogy a géncsalád többi tagja képes átvenni a deletált gén szerepét. Ezen problémák áthidalására jelenthet megoldást a célzott gének túlmüködtetése. C. albicans esetén számos gén overexpressziós rendszert kidolgoztak (Fu és mtsai. 2008, Jin és mtsai. 2008, Chauvel és mtsai. 2012). C. parapsilosis esetén gén overexpressziós rendszer ezidáig nem állt rendelkezésre, ezért munkánk ezen szakaszában célunk volt egy C. parapsilosis-ra optimalizált overexpressziós rendszer kidolgozása. Előzőleg Chauvel és munkatársai $C$. albicans-ban kidolgoztak egy jól müködő rendszert, melynek segítségével rövid időn belül nagy számú gén túlmüködtetése vált lehetségessé (Chauvel és mtsai. 2012). Ezen rendszer esetén a túlmüködtetni kívánt gént, amely egy erős, konstitutív promoter szabályozása alatt áll, a $C$. albicans $R P 10$ régiójába juttatják be. 
C. parapsilosis-on végzett munkánk első lépéseként a $C$. albicans $R P 10$ régióját, a pSFS2 vektor segítségével a $C$. parapsilosis CLIB 214 leucin auxotróf törzsének RP10 régiójába integráltuk, melynek eredményeként a létrehozott törzsben lehetőség nyílik az előzőleg leírt overexpressziós rendszer adaptációjára. Ahhoz, hogy megbizonyosodjunk arról, hogy az így létrehozott törzs képes a majdani overexpressziós vektorok müködtetésére, a Clp10-caTDH3-GFP vektor leucin auxotrófia markert hordozó változatát a létrehozott fogadó törzs $C$. albicans RP10 régiójába integráltuk. Fluoreszcens mikroszkópiás vizsgálataink azt mutatták, hogy a transzformáns telepek minden sejtje GFP pozitív, így a konstitutív TDH3 promoter által müködtetett gén ezen organizmus esetén is kifejeződik. Ezzel megbizonyosodhattunk arról, hogy a $C$. parapsilosis, hasonlóan a $C$. albicans-hoz képes a TDH3 promoter müködtetésére, ezáltal a bejuttatott gén kifejeződése lehetségessé válik ezen fajban is.

Az overexpressziós vektorok rövid időn belüli létrehozásához az Invitrogen cég által kifejlesztett gateway klónozási rendszert alkalmaztuk. Ez a klónozási rendszer a hagyományos klónozással ellentétben a $\lambda$-fágból tisztított helyspecifikus rekombinázokat: a BP és LR klonázokat használja. A helyspecifikus rekombinázok alkalmazásával elkerülhető a hagyományos klónozási folyamat során alkalmazott restrikciós emésztési és ligálási lépés. A gateway rendszer alkalmazása során az első lépés az úgynevezett entry klón létrehozása. Ezen folyamat során a kívánt gén tulajdonképpeni klónozó vektorba juttatása történik meg. A második lépésben zajlik le a destination vektor létrehozása. Felhasználástól függően a destination vektor sokféle lehet, így azt nem csak egy gén genomba történő integrációjára, hanem a képződő fehérje kifejeztetésére, tisztítására, riporter rendszerek létrehozásárai is eredményesen lehet használni. Destination vektorként jelen munkában a pTDH3-GTW-LEU2 vektort használtuk. Az első, ilyen módon overexpresszáltatott gén a WOR1 gén, amelynek $C$. albicans béli ortológjáról kimutatták, hogy a white-opaque átmenetben játszik fontos szerepet (Huang és mtsai. 2006). Az elkészített destination vektor C. albicans RP10 régióját hordozó $C$. parapsilosis törzsbe történő sikeres transzformációját követően, a transzformánsok qRT-PCR vizsgála a WOR1 gén expressziójában bekövetkezett mintegy tízszeres overexpressziót mutattak. Ez az eredmény jól mutatja, hogy az alkalmazott rendszer eredményesen használható $C$. parapsilosis génektúlműködtetésére, ezáltal új utat nyit meg a mikroba génjeinek tanulmányozására. A rendszer előnye, hogy a deléciós módszerekkel összevetve jóval rövidebb idő alatt létrehozhatók az overexpressziós mutáns törzsek, így rövid időn belül nagy számú gén vizsgálata (akár a $C$. parapsilosis teljes ORF-om) válik lehetségessé. A TDH3 promoter egy erős, konstitutív promoter, amely nem induktív körülmények között is 
magas szintủ génexpressziót biztosít. Hátránya, hogy ezen promoter alkalmazásával bizonyos mutánsok letális fenotípust mutat(hat)nak. Ezen hátrány kiküszöbölése érdekében jövőbeli terveink közt szerepel a TDH3 promoter cseréje egy más, indukálható promoterre, amellyel ezen veszély elhárítható a rendszer alkalmazása során.

Munkánk eredményei új ismeretekkel bővítették a $C$. parapsilosis szekretált aszpartil proteináz fehérjékkel kapcsolatos ismereteket, valamint sikeresen kidolgoztunk egy új, C. parapsilosis-ra optimalizált overexpressziós rendszer alapjait. A létrehozott deléciós mutánsok felhasználásával módunk nyílt a SAPP gének regulációjának vizsgálatára. In vitro fertőzéses rendszerben vizsgáltuk a Sapp1 fehérje virulenciában betöltött szerepének, továbbá egy Sapp negatív mutáns törzs létrehozásával és felhasználásával tanulmányozhattuk a szekretált aszpartil proteinázok virulenciában betöltött általános szerepét. Kimutattuk, hogy a deléciós mutánsok csökkent virulenciával rendelkeznek. A Sapp fehérjék szerepet játszanak a mikroba humán szérumban való túlélése során, valamint fluoreszcens vizsgálatok során sikeresen kimutattuk, hogy ezen fehérjék jelentős szereppel bírnak a mikroba humán makrofág sejtekben való túlélésében a fagoszóma - lizoszóma fúzió gátlása által. A vad típusú és mutáns törzsek sejtfalösszetétellének analízise kimutatta, hogy a Sapp fehérjéknek jelentős szerep jut a mikroba sejtfalának felépítésében. Munkánk során létrehoztunk egy olyan fogadó törzset, melynek segítségével ezen organizmusban is lehetséges egy overexpressziós stratégia alkalmazása, ezáltal egy új eszköztárral bővítettük a $C$. parapsilosis genetikai módosításának lehetőségeit. 


\section{SUMMARY}

During the last three decades, candidiasis has become the most commonly diagnosed yeast-related infection worldwide. Although Candida species are members of the normal human flora, under specific circumstances they have the ability to turn themselves into pathogenic fungi causing superficial, cutaneous or systemic infections. In most cases Candida species are responsible for nosocomial infections. The major risk factors for opportunistic fungal infections are the prolonged hospitalization, the extended use of antibiotics, use of intravenous catheters and the low birth weight in case of premature neonates. According to recent studies, although the most prevalent species causing invasive candidiasis in adults is $C$. albicans, several studies demonstrated, that in special patient groups especially in case of neonates $C$. parapsilosis is even outmarks $C$. albicans. According to the genetic variability of C. parapsilosis, in 2005 the C. parapsilosis species complex was divided to three different species: $C$. parapsilosis, $C$. orthopsilosis and $C$. metapsilosis. These three groups form the $C$. parapsilosis sensu lato group. Although, in the last two decades candidial infections caused by non-albicans species show an increasing tendency, little is known about the pathomechanism and virulence attributes of these species. It has been shown, that secreted hydrolytic enzymes - especially lipases - play a crucial role in the pathogenicity and virulence of $C$. parapsilosis. Previous studies demonstrated, that $C$. parapsilosis lipase deficient strain has decreased virulence compared to the wild type in several in vitro and in vivo infection models. Even the two main secreted aspartyl proteinases of C. parapsilosis (Sapp1 and Sapp2) are biochemically well characterized, very little is known about the role of these enzymes during host-pathogen interactions. Although for C. albicans several techniques are available for genetic manipulation, the numbers of gene deletion methods in $C$. parapsilosis are limited and, there is no gene over-expression method available for this microbe.

The aims of our study were: 1.: to clarify the role of the C. parapsilosis secreted aspartyl proteinase 1 (Sapp1) in host-pathogen interactions, 2.: to generate a "Sapp negative" secreted aspartyl proteinase deficient strain in C. parapsilosis in order to study the general role of Sapp proteins in host-pathogen interactions, and finally 3.: to establish an overexpression strategy optimized for C. parapsilosis. 


\subsection{The role of secreted aspartyl proteinase 1 (Sapp1) in host-pathogen}

\section{interactions.}

The role of $C$. albicans secreted aspartyl proteinases, as virulence factors in hostpathogen interactions has been extensively investigated (Hube and Naglik 2001). It has been demonstrated, that $C$. albicans sap's are able to degrade several structural and immunologically important proteins of the host, thus assist the invasion of the microbe.

In contrast, the role of the two main proteinases (Sapp1 and Sapp2) (HruskovaHeidingsfeldova, et al. 2009) of C. parapsilosis in virulence and pathogenesis was not studied previously. According to the biochemical studies, the major aspartyl proteinase of $C$. parapsilosis is the Sapp1 protein, thus we first focused on the investigation of Sapp1 in hostpathogen interactions.

The in silico analysis of SAPPI open reading frame using the sequence database of Sanger institute (www.sanger.ac.uk/sequencing/Candida/parapsilosis) revealed two, identical $2871 \mathrm{bp}$ long region in $32 \mathrm{~kb}$ distance from each other in the $C$. parapsilosis genome, that contained the SAPPI ORF. The two copies of the ORF were identified as SAPPIa and SAPP1b. In 2009, Geraldine Butler and her colleagues submitted the annotated genome sequence of $C$. parapsilosis, that confirmed the result of our in silico analysis (Butler, et al. 2009).

In order to investigate the role of the SAPP1 genes we applied the deletion constructs pSFS2Sapp1a and pSFS2Sapp1b and successfully generated SAPP1 deletion mutants. Using the pSFS2Sapp1a construct a $\Delta / \Delta$ sappla homozygous mutant was generated, while using the pSFS2Sapp1b construct - where we deleted the whole duplicated region - a $\Delta / \Delta$ sapp $1 b$ homozygous mutant was generated. Further transformation steps made possible to generate a double deletion mutant where all SAPP1 alleles were eliminated and a $\Delta / \Delta$ sappla- $\Delta / \Delta$ sapp $1 b$ mutant strain was also successfully generated.

The loss of SAPP1 allels was validated in RNA and in protein level as well. Quantitative real-time PCR analysis was performed to measure the transcript levels of SAPP1, SAPP2 and SAPP3 (a putative secreted proteinase like ORF) genes. The wild type strain in proteinase inducing medium showed 80-fold overexpression of SAPP1 while in the $\Delta / \Delta$ sappla- $\Delta / \Delta$ sapp $1 b$ double deletion mutant no SAPPI transcription level was detectable. Interestingly, the SAPP2 expression level was significantly increased in the $\Delta / \Delta$ sappla$\Delta / \Delta$ sapplb mutant in compare to the wild type under inductive conditions. The putative, yet not characterized gene the $S A P P 3$, showed ten-fold overexpression in wild type yeast in 
induction media. However, under the same conditions the homozygous $\Delta / \Delta$ sapplb strain displayed almost no $S A P P 3$ expression. To clarify this finding further sequence analyses were performed. The results indicate a possible deletion of the regulatory region of the SAPP 3 gene that was caused during the generation of the $S A P P 1 b$ deficient mutant.

To investigate the enzyme activities of Sapp1 and Sapp2 proteins, quantitative HPLC measurement was performed using the fluorescent substrate DABCYL-Glu-His-Val-Lys-LeuVal-Glu-EDANS. In the wild type strain both specific peaks of Sapp1 and Sapp2 were detected. Interestingly, the Sapp2 activity in the $\Delta / \Delta$ sappla- $\Delta / \Delta$ sapp $1 b$ mutant strain was significantly increased. Based on the elevated transcript and enzyme activity level of Sapp2 we assume a possible feedback mechanism that monitors the levels of the produced aspartyl proteinase levels. To prove this hypothesis further investigations are necessary. Importantly however, these results demonstrate a strict regulation of the proteinase production in $C$. parapsilosis. A similar regulatory mechanism has been described in C. albicans previously. (Naglik, et al. 2003).

It has been shown, that $C$. albicans Sap proteins are able to degrade the complement proteins of human serum (Gropp, et al. 2009) and enhance the dissemination of the microbe. To investigate whether the C. parapsilosis Sapp1 has similar role, serum susceptibility assay was performed. The presence of the heat inactivated human serum did not alter the growth capacity of the wild type nor the mutant cells. In contrast, the intact human serum inhibited the growth rate of the $\Delta / \Delta$ sappla- $\Delta / \Delta$ sapplb mutant strain in compare to the wild type significantly. It suggests that C. parapsilosis Sapp1 is also able to inactivate some of the defense protein components (complement components, immunoglobulin, defensins etc.) of the human serum. To adequately clarify this result further biochemical studies are required by using purified complement components and C. parapsilosis Sapp1 protein.

Macrophages and other phagocytes play a crucial role in the host innate immune response. The pattern recognition receptors (PRRs) of macrophages are able to recognize the evolutionally conserved pathogen associated molecular patterns (PAMPs) of the pathogens. After the recognition, macrophages are able to phagocytose the invading pathogens. Following the phagocytosis, as a final step the phago-lysosome fusion takes place, that leads to the elimination of the ingested pathogen (Netea, et al. 2008).

To study the process of phagocytosis flow cytometry (FACS) and fluorescent microscopic analysis were performed. The phagocytic capacity of human macrophages (PBMC-DM) were investigated followed by the co-incubation of wild type and homozygous 
deletion mutant cells. The results showed increased phagocytic capacity of PBMC-DM infected with the $\Delta / \Delta$ sappla- $\Delta / \Delta$ sapplb mutant strain. To further dissect the process of engulfment, fluorescent microscopy analysis was performed. Increased phago-lysosome fusion was observed in macrophages infected with $\Delta / \Delta$ sappla- $\Delta / \Delta$ sapp $1 b$ mutant strain in compare to the wild type. These results strongly suggest that Sapp1 has an important role in host-pathogen interaction, during the intracellular survival most likely due to the inhibition of phago-lysosome fusion.

To investigate the final stage of host-pathogen interaction killing assays were performed. Using PBMC and PBMC-DM cells the killing efficiency was monitored after the co-incubation of host cells with wild-type and SAPPI homozygous mutant strains. Both the PBMC, and PBMC-DM showed significantly increased elimination efficiency against the $\Delta / \Delta$ sappla- $\Delta / \Delta$ sapp 1 b mutant cells. Additionally, the damage of the host cells caused by $\Delta / \Delta$ sappla- $\Delta / \Delta$ sapp 1 b mutant strain was significantly decreased compared to the damage caused by the wild-type strain. These results suggest that $C$. parapsilosis Sapp1 has an important role in the maintenance of virulence by inhibiting the intracellular killing efficiency of host cells and by propagating the intracellular survival.

All these data demonstrate that Sapp1 is an important virulence factor of $C$. parapsilosis. Sapp1 is able to degrade host defense proteins, inhibits the phagocytosis, phagolysosome fusion and promotes the intracellular survival of the pathogen.

\subsection{The general role of $C$. parapsilosis secreted proteinases in virulence and host-} pathogen interactions.

The $C$. albicans secreted aspartyl proteinase gene family consists of ten $S A P$ genes (SAP1-SAP10), that are well characterized (Hube and Naglik 2001, Naglik, et al. 2003), however the generation of a $S A P$ deficient strain in $C$. albicans due to the high number of encoding genes is almost impossible. C. parapsilosis has only three SAPP genes (SAPPISAPP3), where SAPP1 and SAPP2 are actively transcribed, while SAPP3 is considered as a pseudogene. For this reason, the generation of a C. parapsilosis SAPP deficient strain is much feasible. Our second aim was to investigate the general role of $C$. parapsilosis Sapps during host-pathogen interactions by generating a $S A P P$ minus strain.

We validated the loss of SAPP2 in transcriptional level by Quantitative Real-Time PCR in inductive $(1 \mathrm{x} \mathrm{YCB}+2 \% \mathrm{BSA})$ and non inductive (YPD) conditions. In the deletion 
mutant strain neither $S A P P 1$, nor $S A P P 2$ mRNA was detectable. The transcriptional level of $S A P P 3$ was also significantly decreased.

To measure the activities of Sapp1 and Sapp2 enzymes the concentrated supernatants of the wild-type, $\Delta / \Delta$ sappla- $\Delta / \Delta$ sapplb and the $\Delta / \Delta$ sappla- $\Delta / \Delta$ sapp $1 b-\Delta / \Delta$ sapp 2 strains were applied. The $\Delta / \Delta$ sappla- $\Delta / \Delta$ sapp $1 b-\Delta / \Delta$ sapp 2 strain showed no proteinase activity, which also validated the loss of $S A P P 1$ and $S A P P 2$ genes.

Our previous results suggested, that $C$. parapsilosis Sapp1 plays an important role by digesting the serum proteins. To investigate, whether the loss of Sapp2 has similar effect, serum susceptibility assay was performed. In intact human serum the growth of the $\Delta / \Delta$ sappla- $\Delta / \Delta$ sapp $1 b-\Delta / \Delta$ sapp 2 strain was significantly decreased after 24 and 48 hours of cultivation. Compared to our previous result, there was no difference between the growth rate of $\Delta / \Delta$ sappla- $\Delta / \Delta$ sapp $1 b$ and $\Delta / \Delta$ sappla- $\Delta / \Delta$ sapp $1 b-\Delta / \Delta$ sapp 2 strains in human serum, suggesting that only Sapp1 has the role in the degradation of the host immune proteins of the human serum.

Similarly, there was no difference in the ratio of phagocytosis by macrophages between $\Delta / \Delta$ sappla- $\Delta / \Delta$ sapp $1 b$ and $\Delta / \Delta$ sappla- $\Delta / \Delta$ sapplb- $\Delta / \Delta$ sapp 2 strains. This result suggests, that Sapp1 has the major role in the inhibition of phagocytosis.

It has been shown, that $C$. albicans Sap1, Sap2 and Sap6 proteins are able to induce the secretion of IL-1 $\beta$, IL-6, TNF- $a$ and additionally, Sap3 is able to induce the production of IL-1 $\beta$ and TNF-a (Pietrella, et al. 2010). To investigate whether C. parapsilosis Sapp proteins can also modulate the host response, the level of pro-inflammatory cytokines (IL-1 $\beta$, IL-6, TNF- $\alpha$ ) produced by PBMC-DM were measured. Although, the infection of the macrophages with $\Delta / \Delta$ sappla- $\Delta / \Delta \operatorname{sapp} 1 b-\Delta / \Delta$ sapp 2 cells resulted in a decreased level of IL$1 \beta$ and IL-6 production, these differences were not significant in compare to the wild type infection. Imoprtantly, we still can not exclude the potential immune modulatory role of the $C$. parapsilosis Sapps, however this need further investigations, using different cell lines and by measuring the anti-inflammatory cytokines as well.

The killing efficiency of the human macrophages was also measured after the coincubation with the Sapp minus deletion strain. We detected a slight increase in the killing efficiency against $\Delta / \Delta$ sappla- $\Delta / \Delta$ sapplb- $\Delta / \Delta$ sapp 2 cells compared to the $\Delta / \Delta$ sappla$\Delta / \Delta$ sapp 1 b mutant, suggesting that Sapp2 could have an additive effect in the intracellular survival of the microbe. 
To analyse the in vivo effect of the secreted proteinases, a non-conventional animal model (Galleria mellonella larvae) was applied. The survival of $G$. mellonella larvae infected with wild-type and $\Delta / \Delta$ sapp $1 a-\Delta / \Delta \operatorname{sapp} 1 b-\Delta / \Delta \operatorname{sapp} 2$ strains were monitored for 14 days after infection, however no significant differences could be observed between the survivals of the infected larvae.

Previous studies indicated, that $C$. albicans Sap9 and Sap10 proteins are GPI anchored and localized in the fungal cell wall. Additionally, they have an important role in the maintenance of cell wall integrity of $C$. albicans (Schild, et al. 2011). Therefore, we analysed the cell wall composition of wild-type, $\Delta / \Delta$ sappla- $\Delta / \Delta$ sapplb and $\Delta / \Delta$ sapp $1 a-\Delta / \Delta$ sapplb$\Delta / \Delta$ sapp 2 strains. Notably, the chitin content of the cell wall was decreased in both deletion mutant, while the glucan content of the $\Delta / \Delta$ sappla- $\Delta / \Delta$ sapp $1 b-\Delta / \Delta$ sapp 2 cells showed elevated level. Scanning electron microscopy demonstrated that the cell wall surface of the $\Delta / \Delta$ sappla- $\Delta / \Delta$ sapp $1 b-\Delta / \Delta$ sapp 2 strain is smoother, compared to wild-type strain. These data demonstrate, that $C$. parapsilosis secreted aspartyl proteinases are not only important virulence factors, but also play a crucial role in the cell wall maintenance.

In summary, $C$. parapsilosis secreted aspartyl proteinases are important factors for the virulence and pathogenesis. They have a major role in the neutralization of immune proteins of the host, inhibition of phagocytosis and they can promote the intracellular survival of the pathogen. Additionally, C. parapsilosis secreted aspartyl proteinases may contribute to the maintenance of the cell wall integrity.

\subsection{Development of an overexpression strategy for $C$. parapsilosis}

Members of the CUG clade are constitutively diploid and lack the sexual cycle. For this reason, in these species, gene deletion process is time intensive and technically challenging. Furthermore, the gene deletion methods are not suitable to investigate the role of essential genes. To bypass this problem and to adequately study a function of a gene of interest, a possible solution is to overexpress the targeted gene. Although in case of $C$. albicans many overexpression systems are available (Fu, et al. 2008, Jin, et al. 2008, Chauvel, et al. 2012), no such strategy is available in C. parapsilosis. Thus, our aim was to develop a new overexpression system for $C$. parapsilosis.

First, we generated a $C$. parapsilosis acceptor strain, that is able to overexpress our gene of interest. Using the caSAT1 flipper system, the RPS10 locus of C. albicans was 
integrated into the locus of the RPS10 locus of the C. parapsilosis CLIB 214 leucine auxotrophic strain.

To investigate, that the generated strain is able to overexpress the gene of interest, a TDH3-GFP containing plasmid was transformed into the acceptor strain. The TDH3 promoter is a strong, constitutive promoter, which allows the active transcription of the GFP reporter gene. Fluorescent microscopic studies revealed, that the transformants are GFP positive, demonstrating that the acceptor strain is suitable for overexpression.

To generate the vectors for overexpression, the Gateway cloning strategy was applied.

As a proof of principle, we selected the WOR1 gene for overexpression. The orthologous of this gene in C. albicans is responsible for white-opaque transition and regulates sexual cycles. The WOR1 containing destination vector was transformed to the $C$. parapsilosis acceptor strain. After transformation the gene expression level of WORI were monitored by qRT-PCR and resulted a more than 10 fold overexpression in the transformants.

In summary, we successfully generated an overexpression system for C. parapsilosis, using the highly efficient Gateway cloning system. This strategy will facilitate the development of overexpression libraries and will definitely help to understand the molecular basis of the pathogenesis and virulence of the important human fungal pathogen, $C$. parapsilosis.

The results of our work provided new insights in the pathomechanisms of $C$. parapsilosis, especially regarding the role of the secreted aspartyl proteinases as virulence factors. Using the generated $S A P P$ mutant strains we investigated the different functions of $C$. parapsilosis secreted proteinases in several in vitro infection models. Our results demonstrate that $S A P P 1$ and also the $S A P P$ deficient $C$. parapsilosis strain display decreased virulence. Sapp proteins play an important role in the survival capacity of the microbe in human serum. Sapps also have a major role in the inhibition of phagocytosis and facilitate the intracellular survival of the pathogen by the inhibiting the phagosomelysosme fusion. The analysis of the cell wall composition suggests that Sapp proteins may have an important role in the maintenance of the cell wall. Additionally, we successfully established a new overexpression strategy optimized to $C$. parapsilosis. This overexpression method provides a new tool for the genetic modification of $C$. parapsilosis. 


\section{IRODALOMJEGYZÉK}

Abad-Zapatero C, Goldman R, Muchmore SW, Hutchins C, Stewart K, Navaza J, Payne CD, Ray TL.(1996) Structure of a secreted aspartic protease from C. albicans complexed with a potent inhibitor: implications for the design of antifungal agents. Protein Sci 5(4):640-52.

Agatensi L, Franchi F, Mondello F, Bevilacqua RL, Ceddia T, De Bernardis F, Cassone A. (1991) Vaginopathic and proteolytic Candida species in outpatients attending a gynaecology clinic. J Clin Pathol 44(10):826-30.

Albrecht A, Felk A, Pichova I, Naglik JR, Schaller M, de Groot P, Maccallum D, Odds FC, Schäfer W, Klis F, Monod M, Hube B. (2006) Glycosylphosphatidylinositol-anchored proteases of Candida albicans target proteins necessary for both cellular processes and hostpathogen interactions. J Biol Chem 281(2):688-94.

Almirante B, Rodríguez D, Cuenca-Estrella M, Almela M, Sanchez F, Ayats J, Alonso-Tarres C, Rodriguez-Tudela JL, Pahissa A. (2006) Epidemiology, risk factors, and prognosis of Candida parapsilosis bloodstream infections: case-control population-based surveillance study of patients in Barcelona, Spain, from 2002 to 2003. J Clin Microbiol 44(5):1681-5.

Anderson J, R. Mihalik, D. R. Soll (1990) Ultrastructure and antigenicity of the unique cell wall pimple of the Candida opaque phenotype. J Bacteriol 172(1):224-35.

Ash J, Dominguez M, Bergeron JJ, Thomas DY, Bourbonnais Y. (1995) The yeast proprotein convertase encoded by YAP3 is a glycophosphatidylinositol-anchored protein that localizes to the plasma membrane. J Biol Chem 270(35):20847-54.

Barelle C. J., Manson CL, MacCallum DM, Odds FC, Gow NA, Brown AJ. (2004) GFP as a quantitative reporter of gene regulation in Candida albicans. Yeast 21(4):333-40.

Barrett-Bee, K, Hayes Y, Wilson RG, Ryley JF. (1985) A comparison of phospholipase activity, cellular adherence and pathogenicity of yeasts. J Gen Microbiol 131(5):1217-21.

Barrett, A. J.(1979) Protein degradation in health and disease. Introduction: the classification of proteinases. Ciba Found Symp (75):1-13.

Barrett, A. J., N. D. Rawlings (1991) Types and families of endopeptidases. Biochem Soc Trans 19(3):707-15.

Basso, L. R., Jr., Bartiss A, Mao Y, Gast CE, Coelho PS, Snyder M, Wong B. (2010) Transformation of Candida albicans with a synthetic hygromycin B resistance gene. Yeast 27(12):1039-48.

Beausejour, A., Grenier D, Goulet JP, Deslauriers N. (1998) Proteolytic activation of the interleukin-1beta precursor by Candida albicans. Infect Immun 66(2):676-81.

Borg-von Zepelin, M., Beggah S, Boggian K, Sanglard D, Monod M. (1998) The expression of the secreted aspartyl proteinases Sap4 to Sap6 from Candida albicans in murine macrophages. Mol Microbiol 28(3):543-54. 
Brockerhoff, H. (1974) Model of interaction of polar lipids, cholesterol, and proteins in biological membranes. Lipids 9(9):645-50.

Brunel, L., Neugnot V, Landucci L, Boze H, Moulin G, Bigey F, Dubreucq E. (2004) Highlevel expression of Candida parapsilosis lipase/acyltransferase in Pichia pastoris. J Biotechnol 111(1):41-50.

Buffo, J., M. A. Herman, D. R. Soll (1984) A characterization of pH-regulated dimorphism in Candida albicans. Mycopathologia 85(1-2):21-30.

Butler, G., Rasmussen MD, Lin MF, Santos MA, Sakthikumar S, Munro CA, Rheinbay E, Grabherr M, Forche A, Reedy JL, Agrafioti I, Arnaud MB, Bates S, Brown AJ, Brunke S, Costanzo MC, Fitzpatrick DA, de Groot PW, Harris D, Hoyer LL, Hube B, Klis FM, Kodira C, Lennard N, Logue ME, Martin R, Neiman AM, Nikolaou E, Quail MA, Quinn J, Santos MC, Schmitzberger FF, Sherlock G, Shah P, Silverstein KA, Skrzypek MS, Soll D, Staggs R, Stansfield I, Stumpf MP, Sudbery PE, Srikantha T, Zeng Q, Berman J, Berriman M, Heitman J, Gow NA, Lorenz MC, Birren BW, Kellis M, Cuomo CA. (2009) Evolution of pathogenicity and sexual reproduction in eight Candida genomes. Nature 459(7247):657-62.

Cabral, V., Chauvel M, Firon A, Legrand M, Nesseir A, Bachellier-Bassi S, Chaudhari Y, Munro CA, d'Enfert C. (2012) Modular gene over-expression strategies for Candida albicans. Methods Mol Biol 845:227-44.

Cassone, A., De Bernardis F, Torosantucci A, Tacconelli E, Tumbarello M, Cauda R. (1999) In vitro and in vivo anticandidal activity of human immunodeficiency virus protease inhibitors. J Infect Dis 180(2):448-53.

Chauvel, M., Nesseir A, Cabral V, Znaidi S, Goyard S, Bachellier-Bassi S, Firon A, Legrand M, Diogo D, Naulleau C, Rossignol T, d'Enfert C. (2012) A versatile overexpression strategy in the pathogenic yeast Candida albicans: identification of regulators of morphogenesis and fitness. PLoS One 7(9):e45912.

Chow, B. D., J. R. Linden, J. M. Bliss (2012) Candida parapsilosis and the neonate: epidemiology, virulence and host defense in a unique patient setting. Expert Rev Anti Infect Ther 10(8):935-46.

Colina, A. R., Aumont F, Deslauriers N, Belhumeur P, de Repentigny L. (1996) Evidence for degradation of gastrointestinal mucin by Candida albicans secretory aspartyl proteinase. Infect Immun 64(11):4514-9.

Connolly, L. A., Riccombeni A, Grózer Z, Holland LM, Lynch DB, Andes DR, Gácser A, Butler G. (2013) The APSES transcription factor Efg1 is a global regulator that controls morphogenesis and biofilm formation in Candida parapsilosis. Mol Microbiol 90(1):36-53.

Dagdeviren, M., N. Cerikcioglu, M. Karavus (2005) Acid proteinase, phospholipase and adherence properties of Candida parapsilosis strains isolated from clinical specimens of hospitalised patients. Mycoses 48(5):321-6.

Davies, D. R. (1990) The structure and function of the aspartic proteinases. Annu Rev Biophys Biophys Chem 19:189-215. 
De Bernardis, F., Agatensi L, Ross IK, Emerson GW, Lorenzini R, Sullivan PA, Cassone A. (1990) Evidence for a role for secreted aspartate proteinase of Candida albicans in vulvovaginal candidiasis. J Infect Dis 161(6):1276-83.

De Bernardis, F., Arancia S, Morelli L, Hube B, Sanglard D, Schäfer W, Cassone A. (1999)Evidence that members of the secretory aspartyl proteinase gene family, in particular SAP2, are virulence factors for Candida vaginitis. J Infect Dis 179(1):201-8.

De Bernardis, F., Chiani P, Ciccozzi M, Pellegrini G, Ceddia T, D'Offizzi G, Quinti I, Sullivan PA, Cassone A. (1996) Elevated aspartic proteinase secretion and experimental pathogenicity of Candida albicans isolates from oral cavities of subjects infected with human immunodeficiency virus. Infect Immun 64(2):466-71.

Dias, J. C., Rezende RP, Rosa CA, Lachance MA, Linardi VR. (2000) Enzymatic degradation of nitriles by a Candida guilliermondii UFMG-Y65. Can J Microbiol 46(6):525-31.

Ding, C., Butler G. (2007) Development of a gene knockout system in Candida parapsilosis reveals a conserved role for BCR1 in biofilm formation. Eukaryot Cell 6(8):1310-9.

Dmytruk, K. V., Yatsyshyn VY, Sybirna NO, Fedorovych DV, Sibirny AA. (2011) Metabolic engineering and classic selection of the yeast Candida famata (Candida flareri) for construction of strains with enhanced riboflavin production. Metab Eng 13(1):82-8.

Dostal, J., Brynda J, Hrusková-Heidingsfeldová O, Sieglová I, Pichová I, Rezácová P. (2009) The crystal structure of the secreted aspartic protease 1 from Candida parapsilosis in complex with pepstatin A. J Struct Biol 167(2):145-52.

Dostal, J., Dlouhá H, Malon P, Pichová I, Hrusková-Heidingsfeldová O. (2005) The precursor of secreted aspartic proteinase Sapplp from Candida parapsilosis can be activated both autocatalytically and by a membrane-bound processing proteinase. Biol Chem 386(8):791-9.

Drobacheff, C., Millon L, Monod M, Piarroux R, Robinet E, Laurent R, Meillet D. (2001) Increased serum and salivary immunoglobulins against Candida albicans in HIV-infected patients with oral candidiasis. Clin Chem Lab Med 39(6):519-26.

Fallon, K., Bausch K, Noonan J, Huguenel E, Tamburini P. (1997) Role of aspartic proteases in disseminated Candida albicans infection in mice. Infect Immun 65(2):551-6.

Felk, A., Kretschmar M, Albrecht A, Schaller M, Beinhauer S, Nichterlein T, Sanglard D, Korting HC, Schäfer W, Hube B. (2002) Candida albicans hyphal formation and the expression of the Efg1-regulated proteinases Sap4 to Sap6 are required for the invasion of parenchymal organs. Infect Immun 70(7):3689-700.

Fernanado, P. H., Panagoda G. J., L. P. Samaranayake (1999) The relationship between the acid and alkaline phosphatase activity and the adherence of clinical isolates of Candida parapsilosis to human buccal epithelial cells. APMIS 107(11):1034-42. 
Fernandez-Arenas, E., Bleck CK, Nombela C, Gil C, Griffiths G, Diez-Orejas R. (2009) Candida albicans actively modulates intracellular membrane trafficking in mouse macrophage phagosomes. Cell Microbiol 11(4):560-89.

Filippidi, A., Galanakis E, Maraki S, Galani I, Drogari-Apiranthitou M, Kalmanti M, Mantadakis E, Samonis G. (2014) The effect of maternal flora on Candida colonisation in the neonate. Mycoses 57(1):43-8.

Filler, S. G., Ibe BO, Luckett PM, Raj JU, Edwards JE Jr. (1991) Candida albicans stimulates endothelial cell eicosanoid production. J Infect Dis 164(5):928-35.

Fonzi, W. A., M. Y. Irwin (1993) Isogenic strain construction and gene mapping in Candida albicans. Genetics 134(3):717-28.

Fu, Y., Luo G, Spellberg BJ, Edwards JE Jr, Ibrahim AS. (2008) Gene overexpression/suppression analysis of candidate virulence factors of Candida albicans. Eukaryot Cell 7(3):483-92.

Gacser, A., S. Salomon, W. Schafer (2005) Direct transformation of a clinical isolate of Candida parapsilosis using a dominant selection marker. FEMS Microbiol Lett 245(1):117-21.

Gacser, A., Schäfer W, Nosanchuk JS, Salomon S, Nosanchuk JD. (2007a) Virulence of Candida parapsilosis, Candida orthopsilosis, and Candida metapsilosis in reconstituted human tissue models. Fungal Genet Biol 44(12):1336-41.

Gacser, A., Stehr F, Kröger C, Kredics L, Schäfer W, Nosanchuk JD. (2007b) Lipase 8 affects the pathogenesis of Candida albicans. Infect Immun 75(10):4710-8.

Gacser, A., Trofa D, Schäfer W, Nosanchuk JD. (2007c) Targeted gene deletion in Candida parapsilosis demonstrates the role of secreted lipase in virulence. J Clin Invest 117(10):304958.

Gagnon-Arsenault, I., J. Tremblay, Y. Bourbonnais (2006)Fungal yapsins and cell wall: a unique family of aspartic peptidases for a distinctive cellular function. FEMS Yeast Res 6(7):966-78.

Ghannoum, M. A. (2000) Potential role of phospholipases in virulence and fungal pathogenesis. Clin Microbiol Rev 13(1):122-43, table of contents.

Ghannoum, M., K. Abu Elteen (1986) Correlative relationship between proteinase production, adherence and pathogenicity of various strains of Candida albicans. J Med Vet Mycol 24(5):407-13.

Gossen, M., A. L. Bonin, H. Bujard (1993) Control of gene activity in higher eukaryotic cells by prokaryotic regulatory elements. Trends Biochem Sci 18(12):471-5.

Gow, N. A., van de Veerdonk FL, Brown AJ, Netea MG. (2012) Candida albicans morphogenesis and host defence: discriminating invasion from colonization. Nat Rev Microbiol 10(2):112-22. 
Gropp, K., Schild L, Schindler S, Hube B, Zipfel PF, Skerka C. (2009) The yeast Candida albicans evades human complement attack by secretion of aspartic proteases. Mol Immunol 47(2-3):465-75.

Hara, A., Arie M, Kanai T, Matsui T, Matsuda H, Furuhashi K, Ueda M, Tanaka A. (2001) Novel and convenient methods for Candida tropicalis gene disruption using a mutated hygromycin B resistance gene. Arch Microbiol 176(5):364-9.

Hartley, J. L., Temple G. F., M. A. Brasch (2000) DNA cloning using in vitro site-specific recombination. Genome Res 10(11):1788-95.

Hruskova-Heidingsfeldova, O. (2008) Secreted proteins of Candida albicans. Front Biosci 13:7227-42.

Hruskova-Heidingsfeldova, O., Dostál J, Majer F, Havlíkova J, Hradilek M, Pichová I. (2009) Two aspartic proteinases secreted by the pathogenic yeast Candida parapsilosis differ in expression pattern and catalytic properties. Biol Chem 390(3):259-68.

Huang, G., Wang H, Chou S, Nie X, Chen J, Liu H. (2006) Bistable expression of WOR1, a master regulator of white-opaque switching in Candida albicans. Proc Natl Acad Sci U S A 103(34):12813-8.

Hube, B. (1998) Possible role of secreted proteinases in Candida albicans infections. Rev Iberoam Micol 15(2):65-8.

Hube, B., J. Naglik (2001) Candida albicans proteinases: resolving the mystery of a gene family. Microbiology 147(Pt 8):1997-2005.

Hube, B., Stehr F, Bossenz M, Mazur A, Kretschmar M, Schäfer W. (2000) Secreted lipases of Candida albicans: cloning, characterisation and expression analysis of a new gene family with at least ten members. Arch Microbiol 174(5):362-74.

Jacobsen, I. D. (2014) Galleria mellonella as a model host to study virulence of Candida. Virulence 5(2):237-9.

Jayatilake, J. A., Y. H. Samaranayake, L. P. Samaranayake (2005) An ultrastructural and a cytochemical study of candidal invasion of reconstituted human oral epithelium. J Oral Pathol Med 34(4):240-6.

Jin, R., Dobry CJ, McCown PJ, Kumar A. (2008) Large-scale analysis of yeast filamentous growth by systematic gene disruption and overexpression. Mol Biol Cell 19(1):284-96.

Kakar, S. N., P. T. Magee (1982) Genetic analysis of Candida albicans: identification of different isoleucine-valine, methionine, and arginine alleles by complementation. J Bacteriol 151(3):1247-52.

Kantarcioglu, A. S., A. Yucel (2002) Phospholipase and protease activities in clinical Candida isolates with reference to the sources of strains. Mycoses 45(5-6):160-5. 
Kaur, R., B. Ma, B. P. Cormack (2007) A family of glycosylphosphatidylinositol-linked aspartyl proteases is required for virulence of Candida glabrata. Proc Natl Acad Sci U S A 104(18):7628-33.

Kilian, M., J. Mestecky, M. W. Russell (1988) Defense mechanisms involving Fc-dependent functions of immunoglobulin $\mathrm{A}$ and their subversion by bacterial immunoglobulin $\mathrm{A}$ proteases. Microbiol Rev 52(2):296-303.

Kim, S. K., K. El Bissati, C. Ben Mamoun (2006) Amino acids mediate colony and cell differentiation in the fungal pathogen Candida parapsilosis. Microbiology 152(Pt 10):2885-94.

Kohler, G. A., T. C. White, N. Agabian (1997) Overexpression of a cloned IMP dehydrogenase gene of Candida albicans confers resistance to the specific inhibitor mycophenolic acid. J Bacteriol 179(7):2331-8.

Komano, H., R. S. Fuller (1995) Shared functions in vivo of a glycosyl-phosphatidylinositollinked aspartyl protease, Mkc7, and the proprotein processing protease Kex2 in yeast. Proc Natl Acad Sci U S A 92(23):10752-6.

Korting, H. C., Schaller M, Eder G, Hamm G, Böhmer U, Hube B. (1999) Effects of the human immunodeficiency virus (HIV) proteinase inhibitors saquinavir and indinavir on in vitro activities of secreted aspartyl proteinases of Candida albicans isolates from HIV-infected patients. Antimicrob Agents Chemother 43(8):2038-42.

Kosa, P., B. Gavenciakova, J. Nosek (2007)Development of a set of plasmid vectors for genetic manipulations of the pathogenic yeast Candida parapsilosis. Gene 396(2):338-45.

Kovac, L., J. Lazowska, P. P. Slonimski (1984) A yeast with linear molecules of mitochondrial DNA. Mol Gen Genet 197(3):420-4.

Kretschmar, M., Hube B, Bertsch T, Sanglard D, Merker R, Schröder M, Hof H, Nichterlein T. (1999) Germ tubes and proteinase activity contribute to virulence of Candida albicans in murine peritonitis. Infect Immun 67(12):6637-42.

Kreusch, A., A. S. Karstaedt (2013) Candidemia among adults in Soweto, South Africa, 1990-2007. Int J Infect Dis 17(8):e621-3.

Krysan, D. J., Ting EL, Abeijon C, Kroos L, Fuller RS. (2005) Yapsins are a family of aspartyl proteases required for cell wall integrity in Saccharomyces cerevisiae. Eukaryot Cell 4(8):1364-74.

Laffey, S. F., G. Butler (2005) Phenotype switching affects biofilm formation by Candida parapsilosis. Microbiology 151(Pt 4):1073-81.

Lipke, P. N., R. Ovalle (1998) Cell wall architecture in yeast: new structure and new challenges. J Bacteriol 180(15):3735-40.

Macdonald, F., F. C. Odds (1980) Purified Candida albicans proteinase in the serological diagnosis of systemic candidosis. JAMA 243(23):2409-11. 
Macdonald, F., F. C. Odds (1983) Virulence for mice of a proteinase-secreting strain of Candida albicans and a proteinase-deficient mutant. J Gen Microbiol 129(2):431-8.

Mardon, D., E. Balish, A. W. Phillips (1969) Control of dimorphism in a biochemical variant of Candida albicans. J Bacteriol 100(2):701-7.

Merkerova, M., Dostál J, Hradilek M, Pichová I, Hrusková-Heidingsfeldová O. (2006) Cloning and characterization of Sapp2p, the second aspartic proteinase isoenzyme from Candida parapsilosis. FEMS Yeast Res 6(7):1018-26.

Millerioux, Y., Clastre M, Simkin AJ, Courdavault V, Marais E, Sibirny AA, Noël T, Crèche J, Giglioli-Guivarc'h N, Papon N. (2011) Drug-resistant cassettes for the efficient transformation of Candida guilliermondii wild-type strains. FEMS Yeast Res 11(6):457-63.

Monod, M., Togni G, Hube B, Sanglard D. (1994) Multiplicity of genes encoding secreted aspartic proteinases in Candida species. Mol Microbiol 13(2):357-68.

Moran, C., Grussemeyer CA, Spalding JR, Benjamin DK Jr, Reed SD. (2009) Candida albicans and non-albicans bloodstream infections in adult and pediatric patients: comparison of mortality and costs. Pediatr Infect Dis J 28(5):433-5.

Morrow, B., H. Ramsey, D. R. Soll (1994) Regulation of phase-specific genes in the more general switching system of Candida albicans strain 3153A. J Med Vet Mycol 32(4):287-94.

Morrow, B., Srikantha T, Anderson J, Soll DR. (1993) Coordinate regulation of two opaquephase-specific genes during white-opaque switching in Candida albicans. Infect Immun 61(5):1823-8.

Morschhauser, J., S. Michel, P. Staib (1999) Sequential gene disruption in Candida albicans by FLP-mediated site-specific recombination. Mol Microbiol 32(3):547-56.

Morschhauser, J., P. Staib, G. Kohler (2005) Targeted gene deletion in Candida albicans wildtype strains by MPAR flipping. Methods Mol Med 118:35-44.

Morschhauser, J., Virkola R, Korhonen TK, Hacker J. (1997) Degradation of human subendothelial extracellular matrix by proteinase-secreting Candida albicans. FEMS Microbiol Lett 153(2):349-55.

Murad, A. M., Lee PR, Broadbent ID, Barelle CJ, Brown AJ. (2000) CIp10, an efficient and convenient integrating vector for Candida albicans. Yeast 16(4):325-7.

Naglik, J. R., S. J. Challacombe, B. Hube (2003) Candida albicans secreted aspartyl proteinases in virulence and pathogenesis. Microbiol Mol Biol Rev 67(3):400-28.

Nakayama, H., Mio T, Nagahashi S, Kokado M, Arisawa M, Aoki Y. (2000) Tetracyclineregulatable system to tightly control gene expression in the pathogenic fungus Candida albicans. Infect Immun 68(12):6712-9.

Netea, M. G., Brown GD, Kullberg BJ, Gow NA.(2008) An integrated model of the recognition of Candida albicans by the innate immune system. Nat Rev Microbiol 6(1):67-78. 
Neu, N., Malik M, Lunding A, Whittier S, Alba L, Kubin C, Saiman L.(2009) Epidemiology of candidemia at a Children's hospital, 2002 to 2006. Pediatr Infect Dis J 28(9):806-9.

Nguyen, L. N., Hamari Z, Kadereit B, Trofa D, Agovino M, Martinez LR, Gacser A, Silver DL, Nosanchuk JD. (2011) Candida parapsilosis fat storage-inducing transmembrane (FIT) protein 2 regulates lipid droplet formation and impacts virulence. Microbes Infect 13(7):66372.

Nguyen, L. N., J. D. Nosanchuk (2011) Lipid droplet formation protects against gluco/lipotoxicity in Candida parapsilosis: an essential role of fatty acid desaturase Ole1. Cell Cycle 10(18):3159-67.

Nguyen, L. N., D. Trofa, J. D. Nosanchuk (2009) Fatty acid synthase impacts the pathobiology of Candida parapsilosis in vitro and during mammalian infection. PLoS One 4(12):e8421.

Noble, S. M., A. D. Johnson (2005) Strains and strategies for large-scale gene deletion studies of the diploid human fungal pathogen Candida albicans. Eukaryot Cell 4(2):298-309.

Noble, S. M., A. D. Johnson (2007) Genetics of Candida albicans, a diploid human fungal pathogen. Annu Rev Genet 41:193-211.

Nosek, J., Dinouël N, Kovac L, Fukuhara H. (1995) Linear mitochondrial DNAs from yeasts: telomeres with large tandem repetitions. Mol Gen Genet 247(1):61-72.

Nucci, M., Queiroz-Telles F, Alvarado-Matute T, Tiraboschi IN, Cortes J, Zurita J, GuzmanBlanco M, Santolaya ME, Thompson L, Sifuentes-Osornio J, Echevarria JI, Colombo AL; Latin American Invasive Mycosis Network. (2013) Epidemiology of candidemia in Latin America: a laboratory-based survey. PLoS One 8(3):e59373.

Pammi, M., Holland L, Butler G, Gacser A, Bliss JM. (2013) Candida parapsilosis is a significant neonatal pathogen: a systematic review and meta-analysis. Pediatr Infect Dis J 32(5):e206-16.

Panagoda, G. J., A. N. Ellepola, L. P. Samaranayake (2001) Adhesion of Candida parapsilosis to epithelial and acrylic surfaces correlates with cell surface hydrophobicity. Mycoses 44(12):29-35.

Papon, N., Courdavault V, Clastre M, Bennett RJ. (2013) Emerging and emerged pathogenic Candida species: beyond the Candida albicans paradigm. PLoS Pathog 9(9):e1003550.

Papon, N., Courdavault V, Clastre M, Simkin AJ, Crèche J, Giglioli-Guivarc'h N. (2012) Deus ex Candida genetics: overcoming the hurdles for the development of a molecular toolbox in the CTG clade. Microbiology 158(Pt 3):585-600.

Pappas, P. G., Rex JH, Lee J, Hamill RJ, Larsen RA, Powderly W, Kauffman CA, Hyslop N, Mangino JE, Chapman S, Horowitz HW, Edwards JE, Dismukes WE; NIAID Mycoses Study Group. (2003) A prospective observational study of candidemia: epidemiology, therapy, and influences on mortality in hospitalized adult and pediatric patients. Clin Infect Dis 37(5):63443. 
Park, Y. N., J. Morschhauser (2005) Tetracycline-inducible gene expression and gene deletion in Candida albicans. Eukaryot Cell 4(8):1328-42.

Parm, U., Metsvaht T, Sepp E, Ilmoja ML, Pisarev H, Pauskar M, Lutsar I. (2011) Risk factors associated with gut and nasopharyngeal colonization by common Gram-negative species and yeasts in neonatal intensive care units patients. Early Hum Dev 87(6):391-9.

Pereira, E., Figueira C, Aguiar N, Vasconcelos R, Vasconcelos S, Calado G, Brandão J, Prada S. (2013) Microbiological and mycological beach sand quality in a volcanic environment: Madeira archipelago, Portugal. Sci Total Environ 461-462:469-79.

Pfaller, M. A., D. J. Diekema (2007)Epidemiology of invasive candidiasis: a persistent public health problem. Clin Microbiol Rev 20(1):133-63.

Pfaller, M. A., Diekema DJ, Gibbs DL, Newell VA, Meis JF, Gould IM, Fu W, Colombo AL, Rodriguez-Noriega E; Global Antifungal Surveillance Study. (2007) Results from the ARTEMIS DISK Global Antifungal Surveillance study, 1997 to 2005: an 8.5-year analysis of susceptibilities of Candida species and other yeast species to fluconazole and voriconazole determined by CLSI standardized disk diffusion testing. J Clin Microbiol 45(6):1735-45.

Pichova, I., Pavlícková L, Dostál J, Dolejsí E, Hrusková-Heidingsfeldová O, Weber J, Ruml T, Soucek M. (2001) Secreted aspartic proteases of Candida albicans, Candida tropicalis, Candida parapsilosis and Candida lusitaniae. Inhibition with peptidomimetic inhibitors. Eur J Biochem 268(9):2669-77.

Pietrella, D., Rachini A, Pandey N, Schild L, Netea M, Bistoni F, Hube B, Vecchiarelli A. (2010) The Inflammatory response induced by aspartic proteases of Candida albicans is independent of proteolytic activity. Infect Immun 78(11):4754-62.

Pryszcz, L. P., Németh T, Gácser A, Gabaldón T. (2013) Unexpected genomic variability in clinical and environmental strains of the pathogenic yeast Candida parapsilosis. Genome Biol Evol 5(12):2382-92.

Pugh, D., R. A. Cawson (1977) The cytochemical localization of phospholipase in Candida albicans infecting the chick chorio-allantoic membrane. Sabouraudia 15(1):29-35.

Reuss, O., Vik A, Kolter R, Morschhäuser J. (2004) The SAT1 flipper, an optimized tool for gene disruption in Candida albicans. Gene 341:119-27.

Roemer, T., Jiang B, Davison J, Ketela T, Veillette K, Breton A, Tandia F, Linteau A, Sillaots S, Marta C, Martel N, Veronneau S, Lemieux S, Kauffman S, Becker J, Storms R, Boone C, Bussey H. (2003) Large-scale essential gene identification in Candida albicans and applications to antifungal drug discovery. Mol Microbiol 50(1):167-81.

Ruchel, R. (1986) Cleavage of immunoglobulins by pathogenic yeasts of the genus Candida. Microbiol Sci 3(10):316-9. 
Sahni, N., Yi S, Daniels KJ, Huang G, Srikantha T, Soll DR. (2010) Tec1 mediates the pheromone response of the white phenotype of Candida albicans: insights into the evolution of new signal transduction pathways. PLoS Biol 8(5):e1000363.

Samaranayake, D. P., S. D. Hanes (2011) Milestones in Candida albicans gene manipulation. Fungal Genet Biol 48(9):858-65.

Schaller, M., Borelli C, Korting HC, Hube B. (2005) Hydrolytic enzymes as virulence factors of Candida albicans. Mycoses 48(6):365-77.

Schaller, M., Korting HC, Schäfer W, Bastert J, Chen W, Hube B. (1999) Secreted aspartic proteinase (Sap) activity contributes to tissue damage in a model of human oral candidosis. Mol Microbiol 34(1):169-80.

Schild, L., Heyken A, de Groot PW, Hiller E, Mock M, de Koster C, Horn U, Rupp S, Hube B. (2011) Proteolytic cleavage of covalently linked cell wall proteins by Candida albicans Sap9 and Sap10. Eukaryot Cell 10(1):98-109.

Schroppel, K., Sprösser K, Whiteway M, Thomas DY, Röllinghoff M, Csank C. (2000) Repression of hyphal proteinase expression by the mitogen-activated protein (MAP) kinase phosphatase Cpplp of Candida albicans is independent of the MAP kinase Cek1p. Infect Immun 68(12):7159-61.

Schweizer, A., Rupp S, Taylor BN, Röllinghoff M, Schröppel K. (2000) The TEA/ATTS transcription factor $\mathrm{CaTec} 1 \mathrm{p}$ regulates hyphal development and virulence in Candida albicans. Mol Microbiol 38(3):435-45.

Seider, K., Heyken A, Lüttich A, Miramón P, Hube B. (2010) Interaction of pathogenic yeasts with phagocytes: survival, persistence and escape. Curr Opin Microbiol 13(4):392-400.

Silva, S., Henriques M, Oliveira R, Azeredo J, Malic S, Hooper SJ, Williams DW. (2009) Characterization of Candida parapsilosis infection of an in vitro reconstituted human oral epithelium. Eur J Oral Sci 117(6):669-75.

Soll, D. R. (1992) High-frequency switching in Candida albicans. Clin Microbiol Rev 5(2):183-203.

Staib, P., Kretschmar M, Nichterlein T, Hof H, Morschhäuser J. (2000) Differential activation of a Candida albicans virulence gene family during infection. Proc Natl Acad Sci U S A 97(11):6102-7.

Staib P, Kretschmar M, Nichterlein T, Hof H, Morschhäuser J. (2002) Transcriptional regulators Cph1p and Efg1p mediate activation of the Candida albicans virulence gene SAP5 during infection. Infect Immun 70(2):921-7.

Stehr, F., Felk A, Gácser A, Kretschmar M, Mähnss B, Neuber K, Hube B, Schäfer W. (2004) Expression analysis of the Candida albicans lipase gene family during experimental infections and in patient samples. FEMS Yeast Res 4(4-5):401-8. 
Strauss, A., S. Michel, J. Morschhauser (2001) Analysis of phase-specific gene expression at the single-cell level in the white-opaque switching system of Candida albicans. J Bacteriol 183(12):3761-9.

Tang, S. J., Sun KH, Sun GH, Chang TY, Wu WL, Lee GC. (2003) A transformation system for the nonuniversal $\mathrm{CUG}(\mathrm{Ser})$ codon usage species Candida rugosa. J Microbiol Methods $52(2): 231-8$.

Tavanti, A., Davidson AD, Gow NA, Maiden MC, Odds FC. (2005) Candida orthopsilosis and Candida metapsilosis spp. nov. to replace Candida parapsilosis groups II and III. J Clin Microbiol 43(1):284-92.

Tortorano, A. M., Prigitano A, Lazzarini C, Passera M, Deiana ML, Cavinato S, De Luca C, Grancini A, Lo Cascio G, Ossi C, Sala E, Montagna MT. (2013) A 1-year prospective survey of candidemia in Italy and changing epidemiology over one decade. Infection 41(3):655-62.

Trofa, D., A. Gacser, J. D. Nosanchuk (2008) Candida parapsilosis, an emerging fungal pathogen. Clin Microbiol Rev 21(4):606-25.

Urlinger, S., Baron U, Thellmann M, Hasan MT, Bujard H, Hillen W. (2000) Exploring the sequence space for tetracycline-dependent transcriptional activators: novel mutations yield expanded range and sensitivity. Proc Natl Acad Sci U S A 97(14):7963-8.

Valach, M., Pryszcz LP, Tomaska L, Gacser A, Gabaldón T, Nosek J. (2012) Mitochondrial genome variability within the Candida parapsilosis species complex. Mitochondrion 12(5):514-9.

Vilanova, M., Teixeira L, Caramalho I, Torrado E, Marques A, Madureira P, Ribeiro A, Ferreira P, Gama M, Demengeot J. (2004) Protection against systemic candidiasis in mice immunized with secreted aspartic proteinase 2. Immunology 111(3):334-42.

Vinterova, Z., Sanda M, Dostál J, Hrušková-Heidingsfeldová O, Pichová I. (2011) Evidence for the presence of proteolytically active secreted aspartic proteinase 1 of Candida parapsilosis in the cell wall. Protein Sci 20(12):2004-12.

Weems, J. J., Jr. (1992) Candida parapsilosis: epidemiology, pathogenicity, clinical manifestations, and antimicrobial susceptibility. Clin Infect Dis 14(3):756-66.

Wilson, R. B., D. Davis, A. P. Mitchell (1999) Rapid hypothesis testing with Candida albicans through gene disruption with short homology regions. J Bacteriol 181(6):1868-74.

Yang, Y. L., Chen HF, Kuo TJ, Lin CY. (2006) Mutations on CaENO1 in Candida albicans inhibit cell growth in the presence of glucose. J Biomed Sci 13(3):313-21.

Zaugg, C., Borg-Von Zepelin M, Reichard U, Sanglard D, Monod M. (2001) Secreted aspartic proteinase family of Candida tropicalis. Infect Immun 69(1):405-12. 


\section{KÖSZÖNETNYILVÁNÍTÁS}

Köszönettel tartozom Prof. Dr. Vágvölgyi Csabának, a Szegedi Tudományegyetem Természettudományi és Informatikai Kar Mikrobiológiai Tanszék vezetőjének, hogy támogatta munkámat és lehetőséget adott, hogy doktori értekezésemet elkészíthessem.

Köszönöm témavezetőmnek Dr. Gácser Attila tudományos főmunkatársnak, hogy magas színvonalú kutatómunkában vehettem részt. Köszönöm továbbá irányadó tanácsait, segítségét és hogy a változatos kutatási témák révén számos gyakorlati technikával és eljárással gazdagodhatott a tudásom.

Köszönettel tartozom Dr. Olga Hrusková-Heidingsfeldová-nak, hogy rendelkezésünkre bocsátotta a szekretált aszpartil proteinázok kimutatására alkalmas fluoreszcens szubsztrátot, valamint a tisztított Sapp1 fehérjét.

Köszönöm Bencsik Ottónak a HPLC vizsgálatban és analízisben nyújtott segítségét.

Köszönet illeti továbbá valamennyi kollaborációs partnerünket, így Joshua D. Nosanchukot értékes tanácsaiért és a publikációink előzetes minősítéséért, Oscar Zaragoza-t a fagoszóma - lizoszóma kolokalizációs vizsgálatban nyújtott segítségéért, valamint Leonardo Nimrichter-t a sejtfalösszetétel vizsgálatban nyújtott segítségéért.

Köszönöm minden kollégámnak: Csonka Katalinnak, Grózer Zsuzsannának, Szenzenstein Juditnak, Tóth Adélnek, Tóth Renátának, Németh Tibornak, Papp Csabának, Luis Antonio Pérez García-nak és Tanmoy Chakraborty-nak; MSC hallgatóinknak Papp Henriettának, Riba Adriennek, BSC hallgatóinknak Bernátsky Reginának, Berta Bálintnak, Molnár Gergőnek segítségüket és a labor kellemes légkörét.

Külön köszönettel tartozom szüleimnek, nővéremnek és páromnak, Geltsch Nikolettának, hogy a doktori munkám alatt támogattak és mellettem álltak. 